\title{
Indicators of occupational employment in the European Union
}

Citation for published version (APA):

Hoevenberg, J., \& de Grip, A. (1994). Indicators of occupational employment in the European Union. Researchcentrum voor Onderwijs en Arbeidsmarkt, Faculteit der Economische Wetenschappen. ROA Reports No. 3E https://doi.org/10.26481/umarep.199403E

Document status and date:

Published: 01/01/1994

DOI:

10.26481/umarep.199403E

Document Version:

Publisher's PDF, also known as Version of record

\section{Please check the document version of this publication:}

- A submitted manuscript is the version of the article upon submission and before peer-review. There can be important differences between the submitted version and the official published version of record.

People interested in the research are advised to contact the author for the final version of the publication, or visit the DOI to the publisher's website.

- The final author version and the galley proof are versions of the publication after peer review.

- The final published version features the final layout of the paper including the volume, issue and page numbers.

Link to publication

\footnotetext{
General rights rights.

- You may freely distribute the URL identifying the publication in the public portal. please follow below link for the End User Agreement:

www.umlib.nl/taverne-license

Take down policy

If you believe that this document breaches copyright please contact us at:

repository@maastrichtuniversity.nl

providing details and we will investigate your claim.
}

Copyright and moral rights for the publications made accessible in the public portal are retained by the authors and/or other copyright owners and it is a condition of accessing publications that users recognise and abide by the legal requirements associated with these

- Users may download and print one copy of any publication from the public portal for the purpose of private study or research.

- You may not further distribute the material or use it for any profit-making activity or commercial gain

If the publication is distributed under the terms of Article $25 \mathrm{fa}$ of the Dutch Copyright Act, indicated by the "Taverne" license above, 


\section{INDICATORS OF OCCUPATIONAL EMPLOYMENT IN THE EUROPEAN UNION}

ROA-R-1994/3E

J. Hoevenberg

A. de Grip

RESEARCH CENTRE FOR EDUCATION AND THE LABOUR MARKET

Faculty of Economics and Business Administration

Rijksuniversiteit Limburg

Maastricht, May 1994 


\section{CIP-GEGEVENS KONINKLIJKE BIBLIOTHEEK, DEN HAAG}

Hoevenberg, J.

Indicators of occupational employment in the European Union / J. Hoevenberg, A. de Grip. Maastricht : Research Centre for Education and the Labour Market, Faculty of Economics and Business Administration, Rijksuniversiteit Limburg. - ([Report] / Researchcentrum voor Onderwijs en Arbeidsmarkt, ISSN 0922-8098; ROA-R-1994/3E)

Met lit. opg.

ISBN 90-5321-128-4 geb.

Trefw.: arbeidsmarkt ; Europese Unie. 


\section{CONTENTS}

INTRODUCTION

1. TRENDS IN THE OCCUPATIONAL STRUCTURE OF EMPLOYMENT 1

1.1. Employment in the European Union 1

1.2. A theoretical framework 4

1.3. Winners and losers on the European labour market 7

1.4. Divergence or convergence of occupational structures

2. SKILL LEVELS AND TRAINING IN THE EUROPEAN LABOUR MARKET 18

2.1. Trends in skill levels in the European Union 18

2.2. The educational level of employment in the
European Union

2.3. Participation in training in the European Union 29

2.4. Some conclusions on upgrading and downgrading in the

3. JOB-SEEKING AND THE STABILITY OF EMPLOYMENT RELATIONSHIPS 35

3.1. Introduction 35

3.2. Job-seeking 35

3.3. Temporary contracts 40

3.4. Part-time work 46

3.5. Some concluding remarks 51

4. THE POSITION OF WOMEN ON THE LABOUR MARKET 54

4.1. Introduction 54

4.2. The occupational structure of female employment 54

4.3. Skill levels and training in the European labour $\begin{array}{ll}\text { market for women } & 67\end{array}$

4.4. Female job-seeking and the stability of employment relationships 89

$\begin{array}{ll}\text { 4.5. Some concluding remarks } & 110\end{array}$

5. TRENDS IN OCCUPATIONAL EMPLOYMENT OF THIRD AGE WORKERS 115

$\begin{array}{ll}5.1 \text { Introduction } & 115\end{array}$

5.2. The occupational structure of third age employment 115

$\begin{array}{lll}5.3 & \text { Job-seeking and the stability of third age workers' employment relationships } 126\end{array}$

$\begin{array}{ll}5.4 \text { Conclusion } & 130\end{array}$

6. CONCLUSION 131

$\begin{array}{ll}\text { REFERENCES } & 136\end{array}$

$\begin{array}{ll}\text { APPENDIX 1. ISCO '68 } & 137\end{array}$ 


\section{INTRODUCTION}

The Research Centre for Education and the Labour Market (ROA), part of the Faculty of Economic Sciences of the University of Limburg, has developed an information system on education and the labour market for the Netherlands. This system was developed for the Dutch Ministry of Education and Science to deliver labour market information for the use of vocational and educational counsellors and to improve the utilization of the population's investment in knowledge and skills, so as to enhance economic potential. The information system makes it possible to analyze the current labour market situation by economic sector, occupation and types of education. It also provides some risk indicators relating to the cyclical sensitivity of employment prospects, and can deliver medium-term forecasts for employment growth and labour supply. (See Heijke \& De Grip, 1991).

This study, that was commissioned by the Directorate-General for Employment, Industrial Relations and Social Affairs of the European Commission, is a first attempt to apply some of these tools to the European labour market. In doing so, we focus on recent information on the occupational and skill structure of employment and related indicators. Due to incompatibility problems this occupational and educational data has thus far not been published. However, by using data a a high level of aggregation it is possible to get around this problem to a great extent. Thus 1-digit occupational data (based on the ISCO' 68) seems to be appropriate for a first attempt to analyze the differences in the occupational structure of employment in the various EU Member States. ${ }^{1}$ At first sight 1983-1991 seemed to be the best period to analyze. However some problems became apparent when examining the data, delivered by Eurostat. First, there was no useful data available for Italy, so Italy had to be excluded from this study. ${ }^{2}$ Second, for several countries there was no data available for some years in the period 19831987. Therefore the study period was limited to $1987-1991 .^{3}$ One last problem to be mentioned here concerns the data for Luxembourg, in which a threshold value of 500 people has been used. This threshold value sometimes results in unrealistic relative employment shifts for Luxembourg in the various tables, although the absolute change is actually very small. As we have to be very careful in interpreting the outcomes for Luxembourg, we list them in the tables but do not interpret this data any further.

The report is organized as follows. Chapter 1 describes some trends in the occupational structure of employment in the European Union. First we give a bird's eye view of employment in Europe and its relative growth or decline in the periods 1983-1987 and 1987-1991. This will give a first indication of what the European labour market looks like and how it has developed since 1983. There will also be a short description, in section 1.2, of some economic theories which enable us to interpret the occupational and skill structure of employment and the shifts in

1. For a more detailed description of occupations in the ISCO '68 see Appendix 1.

2. This means that when we refer to 'the European Union' in this study, it should be noted that Italy is excluded.

3. Data from the period 1983-1987 has been used only in graph 1.2. 
these structures. First we deal with the implications of (neo-) classical international trade theories (Ricardo and Heckscher-Ohlin) concentrating on factor endowments. Second, the neotechnology theory will be described. This theory pictures differences between countries in terms of a country's technical capabilities which cause absolute cost differences. This will also entail some reference to the effects of technological developments on the skill structure of employment (upgrading or downgrading). Third, we will deal with labour market segmentation theory, which divides the labour market in a primary 'good jobs' segment and a secondary 'bad jobs' segment. Finally, we briefly describe the sector theory of Clark, which explains employment changes between economic sectors in terms of sectoral growth patterns of countries. In section 1.3 the analysis focuses on the occupational 'winners and losers' in the national labour markets of the various Member States. 'Winners' are the occupational sectors that show the largest employment growth; 'losers' are those that show shrinking employment. Here we also refer to Clark's sector theory, which indicates that occupations which are mainly to be found in the primary and secondary sectors are declining and that employment in occupations mainly related to the service sectors is increasing. Moreover we give a first indication of upgrading or downgrading processes in as far as these processes are reflected in the occupational structure of employment. Finally in section 1.4 we analyze whether the occupational structures of employment in the Member States have diverged or converged in the last few years.

In chapter 2, the skill level of employment and the rates of participation in training are shown. These give us further indications of the upgrading or downgrading of employment in occupational sectors and also an impression of differences between the various countries, with regard to the quality of the labour force. Where skill requirements rise, due to technological and organizational developments, the increased knowledge can be obtained either by demanding higher skills of new employees, or by having the current labour force participate in additional training. These two ways of adjusting the skill structure of the workforce can be called recruitment policies and training policies, respectively.

Chapter 3 describes some indicators of the stability of employment relationships by analysing the percentage of workers in a particular occupational sector who are looking for another job. A high percentage of workers in search of another job points to unstable employment relations. Some other indicators of the stability of employment relations are the percentage of employees working on temporary contracts and the percentage of employees working part-time. It should be noted that a high percentage of people working on temporary contracts can point both to a flexible employment structure for employers and to employment instability for workers.

In chapter 4 attention is given to the position of women on the labour market in the European Union, differentiated by occupational sectors. In recent decades the labour participation of women has increased quite strongly in a number of European countries. We examine which occupational sectors women are working in and to what extent this differs from the total employment picture. Traditionally there has been a strong association of female employment with care-giving occupations. This study will examine whether this is still the case, or if women 
-iii-

are increasingly employed in other occupations which may traditionally have been masculine domains. The tables used in chapters 1 to 3 will be used again.

Chapter 5 focuses on another specific group, the increasing group of older workers, the socalled third age workers. ${ }^{4}$ Due to social developments, such as changes in post-retirement living standards, a demand for more flexible provisions for retirement has developed. This may influence employers' retirement and training decisions. In the past this group of older workers has often been forced into early retirement or early redundancy in periods of decreasing employment. This leads to a perception that there is discrimination in favour of younger workers. However, in recent decades, birth rates have dropped significantly in most countries within the European Union, (see also Lindley, Wilson and Villagomez, 1992). In the near future this will probably lead to a shortage of young people in certain occupations and an increasing need for highly skilled older workers. Therefore we will examine whether there is already a tendency towards greater labour participation by third age workers in the various occupational sectors.

In chapter 6 some conclusions are drawn about the labour market in the European Union. Some recommendations for further research will also be made.

4. The third age is here defined as workers between 55 and 64 years of age. 


\section{TRENDS IN THE OCCUPATIONAL STRUCTURE OF EMPLOYMENT}

\subsection{Employment in the European Union}

The second half of the eighties was a time of great optimism in Europe. After years of very low growth figures, very few new jobs and high unemployment, economic growth rates start to recover again in most European countries. That this has led to an increasing growth rate for employment in most occupational sectors in the European Union can be seen in figure 1.1.

Figure 1.1. Relative employment growth by occupation in the European Union for $1983-1987^{*}$ and 1987 1991

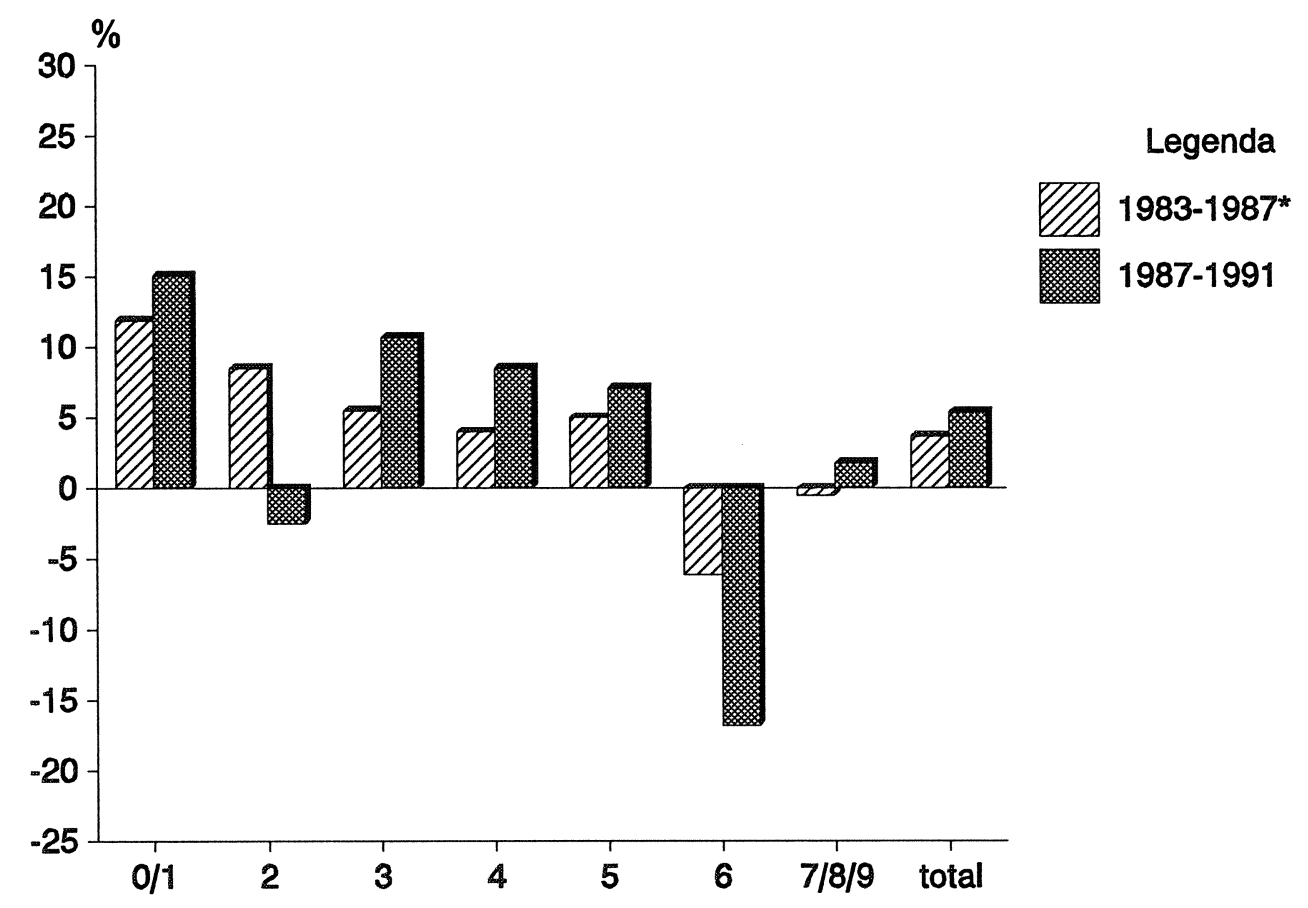

0/1 professional, technical and related workers

$2 \quad$ administrative and managerial workers

$3 \quad$ clerical and related workers

$4 \quad$ sales workers

5 service workers

6 agricultural, animal husbandry and forestry workers, fishermen and hunters

$7 / 8 / 9$ production and related workers, transport equipment operators and labourers

* Spain and Portugal are excluded for this period.

Source: EUROSTAT/ROA

The growth in employment in the European Union increased from 3.7\% for the period 19831987 to $5.4 \%$ for the period $1987-1991$. Most new jobs have been created in the occupational 
sectors of 'professional, technical and related workers', and of 'clerical and related workers'. Employment in these two occupational sectors increased by $15.1 \%$ and $10.7 \%$ respectively. When interpreting figure 1.1 one has to bear in mind that Spain and Portugal are not included in the period 1983-1987, which means that the values for the different periods are comparable to only a limited extent. However, if we exclude Spain and Portugal for the period 1987-1991 the trends stay the same. The figure also shows that employment in the sector of 'agricultural, animal husbandry and forestry workers, fishermen and hunters' decreased enormously. What is surprising is the employment decrease for 'administrative and managerial workers'. However, the negative growth rate for this occupational sector has largely been caused by the employment decrease measured in the United Kingdom, probably due to statistical causes. ${ }^{5}$

Figure 1.2. Occupational employment in the European Union in 1987 and 1991

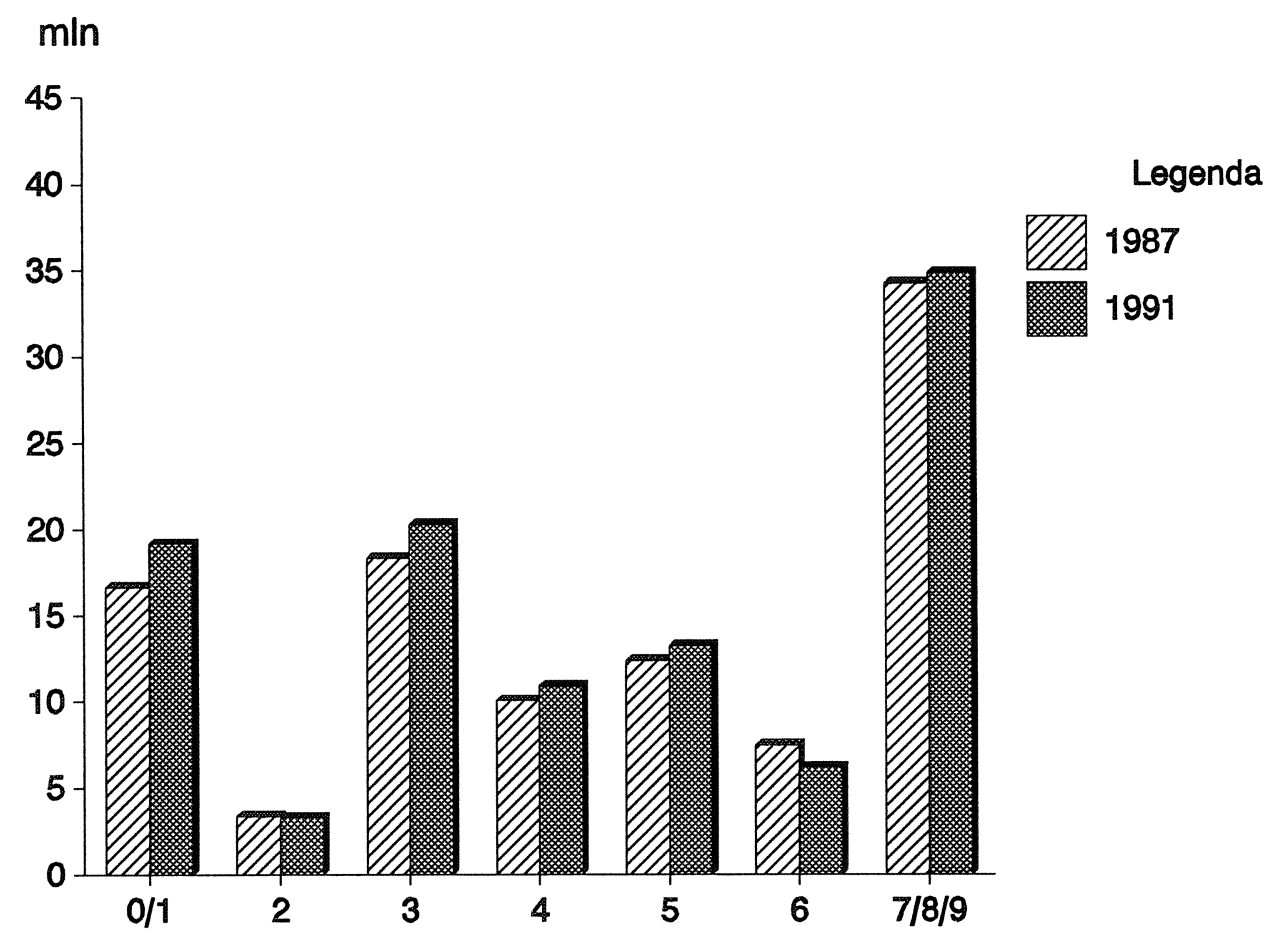

0/1 professional, technical and related workers

$2 \quad$ administrative and managerial workers

$3 \quad$ clerical and related workers

4 sales workers

5 service workers

6 agricultural, animal husbandry and forestry workers, fishermen and hunters

$7 / 8 / 9$ production and related workers, transport equipment operators and labourers

Source: EUROSTAT/ROA

5. From 1988 to 1989 employment for these workers decreased by 0.5 million according to the data. This would mean that their employment share decreased by about $35 \%$ in one year. The reason can be found in differences in interpretation of the definition of this occupational sector in the various countries of the European Union, as described in Dale and Glover (1990). 
From figure 1.2 it can be seen that the employment growth of $5.4 \%$, as described above, has led to an increase in employment of 5.5 million people. However, when the decrease in employment for 'agricultural, animal husbandry and forestry workers, fishermen and hunters' of 1.2 million people is taken into account, a total of 6.7 million new jobs have been created in the European Union in the period 1987-1991. The greater part, approximately 4.5 million new jobs, were created in the occupational sectors of 'professional, technical and related workers' and of 'clerical and related workers'. However, as figure 1.2 shows, the occupational sector of 'production and related workers' is still the largest sector with a total employment of approximately 35 million workers in 1991. Next in rank are the two growth sectors of 'professional, technical and related workers' and 'clerical and related workers' which employ approximately 19 million and 20 million workers respectively. The figure also shows that in the declining occupational sector of 'agricultural, animal husbandry and forestry workers, fishermen and hunters', 6 million workers are still employed.

Figure 1.3 shows how the employment growth is divided over the individual members of the European Union. The Member States in the figure have been divided in three growth categories. Two countries are worth mentioning because of their extreme results. The first country is Denmark. This country showed an increase in employment of $27 \%$ in the period $1987-1991$. However, Denmark is a relative small country and a survey based on a relative small sample may cause measurement errors.

Figure 1.3. Employment growth in the European Union between 1987 and 1991

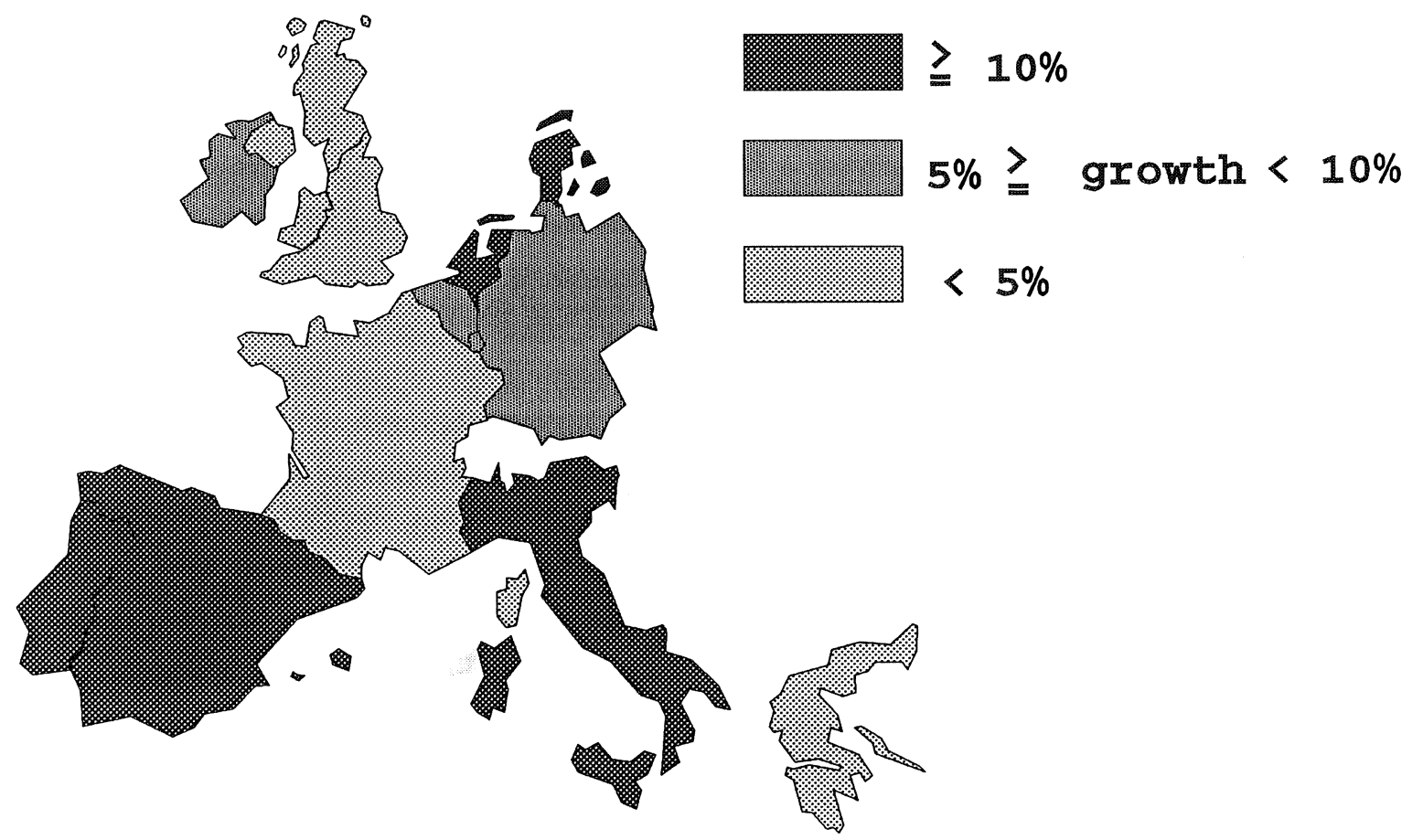

Source: EUROSTAT/ROA 
But it rather seems to be a change in the way the labour force survey in Denmark is conducted, as the working population in Denmark increased between 1987 and 1988 by 0.6 million, to 2.6 million. This means that further on in this report we have to be very careful in interpreting the results for Denmark. The second country worth mentioning is the United Kingdom. This country shows a decrease in total employment of $3.5 \%$ in the period 1987-1991. For this country no irregularities could be found, so we have to assume that employment indeed decreased in this country.

What, now, are the causes of the changes in the occupational structure of employment described above and do these shifts occur in all countries within the European Union? Section 1.2 gives a brief sketch of the economic theory relevant to this question. In section 1.3 the development of the occupational structure of employment in the various EU Member States is shown, classified in terms of winners and losers. The chapter will conclude with and indication of whether the occupational structures of employment in the different Member States have diverged or converged, by means of a divergence/convergence coefficient.

\subsection{A theoretical framework}

In this section, some attention will first be paid to neo-classical international trade theory. We then continue with a short description of the neo-technologists' theory. Then we will describe the main characteristics of labour market segmentation theory. Finally we will describe some aspects of the sector theory of Clark.

\section{Neo-classical international trade theory}

Classical economists attempted to show that even where a country is less efficient in absolute terms than other countries, it will still able to increase its well-being by specializing in those products in which the country is relatively most efficient (Chacholiades, 1978). This theory is known as the theory of comparative advantage and was developed by Ricardo. Because labour is the only flexible production factor in this theory it is very much responsible for price differences between countries and products. Neo-classical economic trade theory formally explains a country's relative advantage by means of its factor endowments. Each country will export the products that make use of the country's most abundant production factor (Heckscher-Ohlin-Samuelson theorem). Free international trade between countries will then cause factor price equalisation (Ethier, 1988). This whole process, however, will be disturbed because of government intervention. Another problem is that the theory assumes that all countries have equal technologies, which is certainly not the case, and that it underestimates the importance of differences in the quality of labour. According to this theory 'high income' European Union countries should specialize in capital-intensive production and the 'lower income' European Union countries should be specializing in labour-intensive products within intra-EU trade. This would mean that industrial occupations, in particular, should decrease in the 'high income countries'. For the 'low income countries' this should mean an increase in employment in the industrial occupations. 
When Leontief applied the Heckscher-Ohlin model to the United States, he came to the conclusion that the Heckscher-Ohlin theory was not applicable, as he found that although the U.S.A. was relatively well endowed with capital, the country exported labour-intensive goods (Leontief, 1953). This became known as the 'Leontief paradox'. The 'Leontief paradox' led economists to place greater emphasis on the dynamics of increasing returns which are strongly associated with production technology and innovation (Dosi, Pavitt, Soete, 1990). This neotechnological theory is based on technological capabilities and innovativeness. By technological capabilities they mean the skills and knowledge necessary to develop, produce and sell products and production processes. Innovativeness is the actual realisation of that capacity to generate and commercialize new and better products and production processes. In this theory technology is both an input and an output. Technical change is the chronic disturber of the existing patterns of comparative advantage. Within this theory there will always be absolute cost differences between countries because of technological capabilities and innovativeness (technological gaps).

Human capital theory assumes that education is an investment that leads to a lasting increase in productive capabilities (Becker, 1983). Several factors can cause shifts in the skill level of employment. First, there is the impact of technological developments or the way management implements new technologies on both the occupational structure and the skill level of employment. Second, there is the combined effect of the degree of competition and of policies aimed at higher quality standards to meet the higher quality demanded by customers. These two factors are strongly related (Groot, 1991). Finally, there is the possibility of substitution of less skilled workers by those more highly skilled if a surplus of educated workers enables employers to raise their skill requirements.

As a matter of fact technological development can have three possible outcomes. First, there may be an upgrading of the skill level required of the workforce. This is based on the assumption that technological development requires more skills, greater responsibility and greater flexibility, to operate in a changing environment, and thus to an increased skill level. Upgrading of the labour force can take place in two ways: by means of recruitment policies or training policies. In the first case more highly skilled people are recruited, in the latter case the current workforce is trained. The second possible outcome is a downgrading of the skill level of the workforce. This hypothesis is based on the assumption that technological developments make tasks simpler and will lead to de-skilling of employment. The third possible outcome is mixed and offsetting movements, a combination of upgrading and downgrading effects (Spenner, 1985). As Bartel and Lichtenberg (1987) point out, in the first stages of the introduction of a technological innovation there will be an upgrading in the workforce, while in the later stages there will be a downgrading tendency. This could mean that the final outcome will show little net change in the skill requirements in the occupational structure, as some occupations will upgrade and others will downgrade. Given that the European Union has high labour costs, and assuming that the European Union wishes to maintain high technological 
capabilities and to be highly innovative, one would expect there to be a continuous process of upgrading in the European Union. Production-related occupational sectors in the European Union, in particular, should show an increase in the skill level of employment.

\section{The labour market segmentation theory}

The theory of labour market segmentation, as presented by Doeringer and Piore (1971), makes a distinction between external (competitive) labour markets and internal labour markets. The primary labour market is formed by two groups of workers. First, there are workers with firmspecific skills which makes it difficult to replace these workers. This also makes it possible to rank jobs by degrees of ability and seniority for promotion or in the event of lay-offs. As a matter of fact these workers are employed on a firm-internal labour market. Second, there are the market segments of workers with skills specific to a craft or profession. Here workers are grouped by occupation. These two groups participate in the primary labour market, in which wages are high and workers have long-term labour contracts and, particularly for the firmspecific workers, good career opportunities. In the secondary segment, however, we find jobs with bad career prospects, part-time jobs, low wages and short-term labour contracts. From the labour market segmentation point of view we would expect women, as they are often associated with care-giving occupations and part-time jobs, to be over-represented in the secondary segment of the labour market.

\section{The sector theory of Clark}

If we are concentrating on employment structure at a national level the sector theory of Clark plays in important role (Clark, 1940). According to this theory the sectoral structure of employment develops in three phases. In the first phase income per capita is very low and employment will be concentrated mainly in the agricultural sector (the primary sector) . $^{6}$ Because of technological developments, per capita income increases more than the demand for primary products. This will cause a growth in employment in the secondary sector of mining, industry and construction. Finally, as per capita income continues to rise, the tertiary or service sector (government, banking, transport and communication, etc.) starts to develop. Although this theory is in fact an economic sector theory, the occupations within the economic sectors are strongly correlated with the development of these economic sectors. For the 'higher income' European Member States this would mean that occupations which are related to the service sector should be the winners on the European labour market, that occupations related to the secondary sector will be losing slightly, and that those related to the primary sector will be the great losers. This should mean a decrease in 'production and related workers, transport equipment operators and labourers' and 'agricultural, animal husbandry and forestry workers, fishermen and hunters' and an increase in 'professional, technical and related workers', 'administrative and managerial workers' and 'clerical and related workers'. For the 'lower

6. It should be noted that this primary sector is not related to the concept of the primary labour market used in the labour market segmentation theory. 
income' Member States we would expect that occupations related to both the secondary sector and the service sector will be the winners on the European labour market and that occupations related to the primary sector will be the great losers again.

\subsection{Winners and losers on the European labour market}

Tables 1.1 to 1.7 give a first indication of the differences in the occupational structure of employment in the various Member States of the European Union, and in the changes in these structures. The various occupational sectors can be generally described as occupational winners or losers, or as stable occupations, and the extent of the shifts in their employment share in the last few years can be indicated.

\section{Winners on the European labour market}

Tables 1.1 and 1.2 refer respectively to the two principal occupational winners: 'professional, technical and related workers' and 'clerical and related workers'. The tables show great differences between countries in both the share of each sector in the country's total employment and the changes in these shares.

Table 1.1. Employment share of professional, technical and related workers (0/1) in 1991 and change (in percentage points) in this share in the period 1987-1991

\begin{tabular}{lcc}
\hline country & $\begin{array}{l}1991 \\
\% \text { of total employed }\end{array}$ & $\begin{array}{c}1987-1991 \\
\text { \%-points change }\end{array}$ \\
\hline Belgium & 22.6 & 1.8 \\
Federal Republic of Germany & 18.3 & 1.6 \\
Denmark & 26.1 & 2.8 \\
Greece & 13.1 & 1.2 \\
Spain & 11.4 & 1.7 \\
France & 18.9 & 0.9 \\
Ireland & 16.4 & 0.1 \\
Luxembourg & 12.7 & 0.0 \\
Netherlands & 24.2 & 1.8 \\
Portugal & 9.7 & 2.5 \\
United Kingdom & 18.4 & 1.6 \\
European Union & & 1.5 \\
\hline
\end{tabular}

Source: EUROSTAT/ROA

For 'professional, technical and related workers', employment shares in 1991 range from 9.7\% in Portugal to $26.1 \%$ in Denmark. Belgium and the Netherlands also have a large share of their total employment in this sector, whereas in Greece and Spain the sector is of lesser importance. This outcome fits very well within the framework of the sector theory of Clark and the international trade theory, as described above, as this occupational sector can be described as a highly-skilled area (see also chapter 2). 
$-8-$

Remarkably, however, Portugal and Denmark had the greatest increase in the share percentages for these occupations, with 2.5 percentage points growth for Portugal and 2.8 percentage points growth for Denmark. This indicates that the occupational structure of employment in Portugal is catching up in this respect. This cannot be said for Greece and Spain, which also have a very low share of their total employment in this occupational sector. In both countries the increases in the employment shares are approximately the same as the European average. Ireland and, to a smaller degree, France have had relatively low increases in the employment share in this occupational sector.

The range of employment shares for 'clerical and related workers' in the various EU Member States is considerably smaller than we saw above for the 'professional, technical and related workers'. In general employment shares differ little from the European average, ranging from $12 \%$ in Greece to $21 \%$ in the Federal Republic of Germany. Other countries with a relatively low employment share for 'clerical and related workers' are Spain, Portugal, Ireland and Denmark. Remarkably, France and the United Kingdom have employment shares for this occupational sector which lie above the European average. This might indicate that the size of this occupational sector is related not only to a country's per capita income, as described in Clark's sector theory, but also to the total population of the country.

Table 1.2. Employment share of clerical and related workers (3) in 1991 and change (in percentage points) in this share in the period 1987-1991

\begin{tabular}{|c|c|c|}
\hline country & $\begin{array}{l}1991 \\
\% \text { of total employed }\end{array}$ & $\begin{array}{l}1987-1991 \\
\% \text {-points change }\end{array}$ \\
\hline Belgium & 20.0 & 1.1 \\
\hline Federal Republic of Germany & 21.0 & 0.9 \\
\hline Denmark & 16.1 & -1.5 \\
\hline Greece & 12.0 & 2.1 \\
\hline Spain & 13.3 & 1.8 \\
\hline France & 20.5 & 0.8 \\
\hline Ireland & 15.8 & 0.1 \\
\hline Luxembourg & 26.2 & 2.7 \\
\hline Netherlands & 18.8 & 1.1 \\
\hline Portugal & 13.8 & 0.7 \\
\hline United Kingdom & 19.6 & 0.9 \\
\hline European Union & 18.8 & 0.9 \\
\hline
\end{tabular}

\section{Source: EUROSTAT/ROA}

The differences in the changes in employment share for the various EU countries, however, are much greater. Changes ranged from a fall of 1.5 percentage points in Denmark to an increase of 2.1 percentage points in Greece. The fall in Denmark is very surprising because it is the only country in which the employment share for this sector decreases. If we look at countries in which this sector is of increasing importance, Greece and Spain seem to be catching up with the other European countries. Where Greece and Spain seem to be stagnating as regards the 
relative employment growth of 'professional, technical and related workers', Portugal seems to be stagnating in the occupational sector of 'clerical and related workers'.

\section{Losers on the European labour market}

In the period 1987-1991 there were two occupational losers on the European labour market: 'agricultural, animal husbandry and forestry workers, fishermen and hunters' and 'production and related workers, transport equipment operators and labourers'. The occupational employment shares of these two occupational sectors had an average decrease of 1.5 percentage points and 1.1 percentage points respectively. For 'agricultural, animal husbandry and forestry workers, fishermen and hunters' the differences between the various EU countries are very great. The employment share of this sector ranges from $2 \%$ in the United Kingdom to $21 \%$ in Greece. The table shows that Portugal, Ireland and Spain also have very high employment shares for this occupational sector. On the other hand, in Belgium and the Federal Republic of Germany the employment shares of this occupational sector are remarkably low. This is very strong support for the sector theory of Clark. According to this theory one would expect a high employment share for 'agricultural, animal husbandry and forestry workers, fishermen and hunters' in the 'lower income' EU countries and a low employment share in the 'high income' EU countries.

From the table it can also be seen that in Greece, Spain and Portugal in particular the share of total employment going to 'agricultural, animal husbandry and forestry workers, fishermen and hunters' decreased very rapidly. This is not surprising as these three countries are characterized by employment shares for this occupational sector which are far above the European average. This decrease in the employment share in these countries would again fit Clark's sector theory. However, the decrease in the employment share is not in accordance with the classical international trade theories, because, given that the EU is a relatively closed market for agricultural production, the factor endowment theory would lead one to expect an increase in the employment share of 'agricultural, animal husbandry and forestry workers, fishermen and hunters' in Spain and Portugal. Even more surprising is the position of Ireland, which shows a high employment share for these workers. However, in comparison to Greece, Spain and Portugal, the employment share of this occupational sector in Ireland fell relatively little.

The other losing occupation, 'production and related workers, transport equipment operators and labourers', has a slightly different profile than the preceding occupational sector. This sector is the most complex to interpret because about one third of total employment in Europe is employed in this occupational sector and the different occupations within it are much more diverse than those in the other occupational sectors, as can be seen in appendix 1 . The employment shares in the various EU countries range from $24.4 \%$ in the Netherlands to $38 \%$ in Spain. In Portugal this occupational sector also has a high employment share. 
Table 1.3. Employment share of agricultural, animal husbandry and forestry workers, fishermen and hunters (6) in 1991 and change (in percentage points) in this share in the period 1987-1991

\begin{tabular}{lcc}
\hline & $\begin{array}{c}1991 \\
\% \text { of total employed }\end{array}$ & $\begin{array}{c}1987-1991 \\
\%-p o i n t s\end{array}$ \\
country & & \\
\hline & 2.7 & -0.5 \\
Belgium & 3.5 & -1.1 \\
Federal Republic of Germany & 4.2 & -0.6 \\
Denmark & 21.0 & -4.4 \\
Greece & 10.4 & -4.2 \\
Spain & 6.3 & -1.4 \\
France & 12.8 & -1.8 \\
Ireland & 4.2 & 0.5 \\
Luxembourg & 4.4 & -0.7 \\
Netherlands & 15.4 & -4.9 \\
Portugal & 2.0 & -0.6 \\
United Kingdom & & -1.5 \\
European Union & 5.8 & \\
\hline
\end{tabular}

Source: EUROSTAT/ROA

Most remarkable is that employment shares in Greece, Spain and Ireland are increasing. At first sight this would seem to point to a comparative cost advantage and high factor endowments of 'blue collar' workers in these countries. However, if this is the case then it is hard to explain why the employment share in this sector decreased in Portugal. One possible answer may be that Portugal has a lack of technical capabilities and innovativeness, which are necessary for the development of this occupational sector.

Table 1.4. Employment share of production and related workers, transport equipment operators and labourers (7/8/9) in 1991 and change (in percentage points) in this share in the period 19871991

\begin{tabular}{|c|c|c|}
\hline country & $\begin{array}{l}1991 \\
\% \text { of total employed }\end{array}$ & $\begin{array}{l}1987-1991 \\
\%-\text { points change }\end{array}$ \\
\hline Belgium & 31.2 & -3.0 \\
\hline Federal Republic of Germany & 34.7 & -1.6 \\
\hline Denmark & 31.5 & -0.6 \\
\hline Greece & 30.9 & 0.2 \\
\hline Spain & 38.0 & 0.3 \\
\hline France & 31.1 & -0.7 \\
\hline Ireland & 28.8 & 0.5 \\
\hline Luxembourg & 33.4 & -3.1 \\
\hline Netherlands & 24.4 & -3.0 \\
\hline Portugal & 36.6 & -0.9 \\
\hline United Kingdom & 29.3 & -1.7 \\
\hline European Union & 32.3 & -1.1 \\
\hline
\end{tabular}


The most exceptional country in table 1.4 is the Netherlands. The Netherlands has the lowest employment share in this occupational sector and the highest decrease in the share of all the EU countries. This might indicate that in this country technically educated production workers are becoming relatively scarce.

\section{Stable occupations}

Changes in the employment shares of the remaining occupational sectors, measured across the EU as a whole, are negligible. However, this does not mean that the differences between countries are by definition smaller. Developments in the various countries of the European Union largely balance each other out, resulting in a stable occupational share at the European level. This can best be seen in the occupational sector of 'administrative and managerial workers'. In five countries the employment share of this occupational sector is decreasing, while in the other six countries the share is increasing. The final result is an average decrease in the employment share over Europe by 0.2 percentage points. Employment shares in this occupational sector range from $0.4 \%$ in France to $5.4 \%$ in the United Kingdom. The employment share in France is extremely low, especially compared to the percentages of Germany and the United Kingdom. This again indicates that the various Member States have different definitions of the occupational sector of 'administrative and managerial workers'.

Table 1.5. Employment share of administrative and managerial workers (2) in 1991 and change (in percentage points) in this share in the period 1987-1991

\begin{tabular}{lcc}
\hline & $\begin{array}{c}1991 \\
\% \text { of total employed }\end{array}$ & $\begin{array}{c}1987-1991 \\
\% \text {-points change }\end{array}$ \\
\hline Belgium & & 0.5 \\
Federal Republic of Germany & 4.2 & -0.2 \\
Denmark & 3.5 & 1.7 \\
Greece & 4.7 & -0.4 \\
Spain & 1.7 & 0.3 \\
France & 1.9 & -0.1 \\
Ireland & 0.4 & 0.6 \\
Luxembourg & 3.7 & -0.3 \\
Netherlands & 1.0 & 0.6 \\
Portugal & 4.7 & 0.7 \\
United Kingdom & 2.0 & -1.3 \\
European Union & 5.4 & -0.2 \\
\hline
\end{tabular}

Source: EUROSTAT/ROA

Furthermore, it can be seen that Greece, Spain and Portugal also show relatively low employment shares for 'administrative and managerial workers' and Belgium, Denmark and the Netherlands show relatively high shares. Denmark and the United Kingdom are the most peculiar in relation to their growth rates. Denmark has the highest increase in the employment share of 'administrative and managerial workers', while having an occupational employment 
share that was already very high ${ }^{7}$. The United Kingdom has the greatest employment share in this occupational sector, but also shows the greatest employment decrease.

The employment shares of 'sales workers' in the various countries within the European Union differ very little from the European average. Greece, Spain, the Netherlands and the United Kingdom have the highest employment shares in this occupational sector and Denmark and France have the lowest. However, the range in the employment shares is only from $8.3 \%$ in Denmark to $11.9 \%$ in Greece. This indicates a rather fixed relation between the employment for 'sales workers' and total employment. Remarkably, the country with the highest employment share of 'sales workers' also had the greatest increase in employment share, while the country with the lowest employment share in this occupational sector also had the greatest decrease in employment share.

Table 1.6. Employment share of sales workers (4) in 1991 and change (in percentage points) in this share in the period 1987-1991

\begin{tabular}{lcc}
\hline & $\begin{array}{l}1991 \\
\% \text { of total employed }\end{array}$ & $\begin{array}{c}\text { 1987-1991 } \\
\text { \%-points change }\end{array}$ \\
\hline country & & \\
Belgium & 9.0 & -0.3 \\
Federal Republic of Germany & 9.4 & 0.1 \\
Denmark & 8.3 & -0.6 \\
Greece & 11.9 & 1.4 \\
Spain & 11.3 & 0.1 \\
France & 8.9 & 0.5 \\
Ireland & 10.7 & -0.2 \\
Luxembourg & 8.8 & 1.3 \\
Netherlands & 11.1 & 0.0 \\
Portugal & 10.0 & 0.8 \\
United Kingdom & 11.3 & 0.5 \\
European Union & 10.1 & 0.3 \\
\hline
\end{tabular}

Source: EUROSTAT/ROA

The employment share of 'service workers' also remained stable at the EU level. However, the range between the highest and lowest employment shares is much greater than for sales workers, varying from $9.2 \%$ in Denmark to $14 \%$ in the United Kingdom. The employment share of 'service workers' in France and Spain is also very high, and very low in the Federal Republic of Germany, Denmark and Greece. Obviously for Germany and Denmark, this outcome is in conflict with Clark's sector theory. However, this effect may be due to technological progress in this occupational sector which enables capital to be substituted for labour. Why Greece also shows such a low employment share for service workers is not clear. Remarkably, Denmark again had the largest decrease in the employment share of 'service workers' while also having the lowest employment share. The largest increase in the employment share of 'service workers' has been achieved by Portugal, with 1.2 percentage points.

7. This result may easily have been caused by measurement errors. 
Table 1.7. Employment share of service workers (5) in 1991 and change (in percentage points) in this share in the period 1987-1991

\begin{tabular}{lcc}
\hline & $\begin{array}{l}1991 \\
\% \text { of total employed }\end{array}$ & $\begin{array}{c}1987-1991 \\
\% \text {-points change }\end{array}$ \\
\hline Belgium & 10.4 & 0.4 \\
Federal Republic of Germany & 9.7 & 0.2 \\
Denmark & 9.2 & -1.2 \\
Greece & 9.3 & -0.1 \\
Spain & 13.7 & 0.0 \\
France & 14.0 & 0.1 \\
Ireland & 11.8 & 0.8 \\
Luxembourg & 13.7 & -1.1 \\
Netherlands & 12.5 & 0.2 \\
Portugal & 12.6 & 1.2 \\
United Kingdom & 14.0 & 0.6 \\
European Union & 12.3 & 0.2 \\
\hline
\end{tabular}

Source: EUROSTAT/ROA

\subsection{Divergence or convergence of occupational structures in the European Union}

Now we have seen the differences in the occupational structure of employment, and in the rate and direction of changes in these structures, in the various EU countries we can ask whether the changes in individual EU countries are leading towards a more homogenous occupational structure in the whole European Union, or to a more heterogenous one. To get an indication of how the occupational structure within the EU countries is changing, a divergence/convergence indicator has been used. This convergence/divergence indicator employs an inverse entropy coefficient, and is defined as follows:

$$
C=1 / \sum_{i=1}^{n} x_{i} \ln \frac{1}{x_{i}}
$$

Where $\mathrm{C}=$ Convergence/divergence indicator

$x_{i}=$ Employment share of an occupational sector within country $i$ as a proportion of European employment in this occupational.

The coefficient measures employment in an occupational sector as a proportion of total European employment in that occupational sector. It reaches its minimum value if the employment shares in all countries in the European Union are equal, which is of course not realistic due to the differences in size of the various countries. However, it is not the level of the coefficient at a certain moment, but rather changes in this level over time, which indicate whether the employment structures are converging or diverging. The coefficient is a measure of concentration, and decreasing values mean that the distribution is becoming more equal. Thus, a decreasing value means convergence. 
Figures 1.3 to 1.9 graph the convergency coefficients of the various occupational sectors. It is striking that most occupational sectors show a small converging trend. The relatively small changes in the coefficients have mainly been caused by the short period for which the coefficients could be calculated. Figure 1.4 with regard to 'administrative and managerial workers' shows the greatest decreasing value. This is caused largely by changes in the United Kingdom. As noted above, the abrupt decrease in the number of people working in this occupation is probably due to definition problems.

Figure 1.3. Convergency of professional, technical and related workers (0/1) from 1987 to 1991

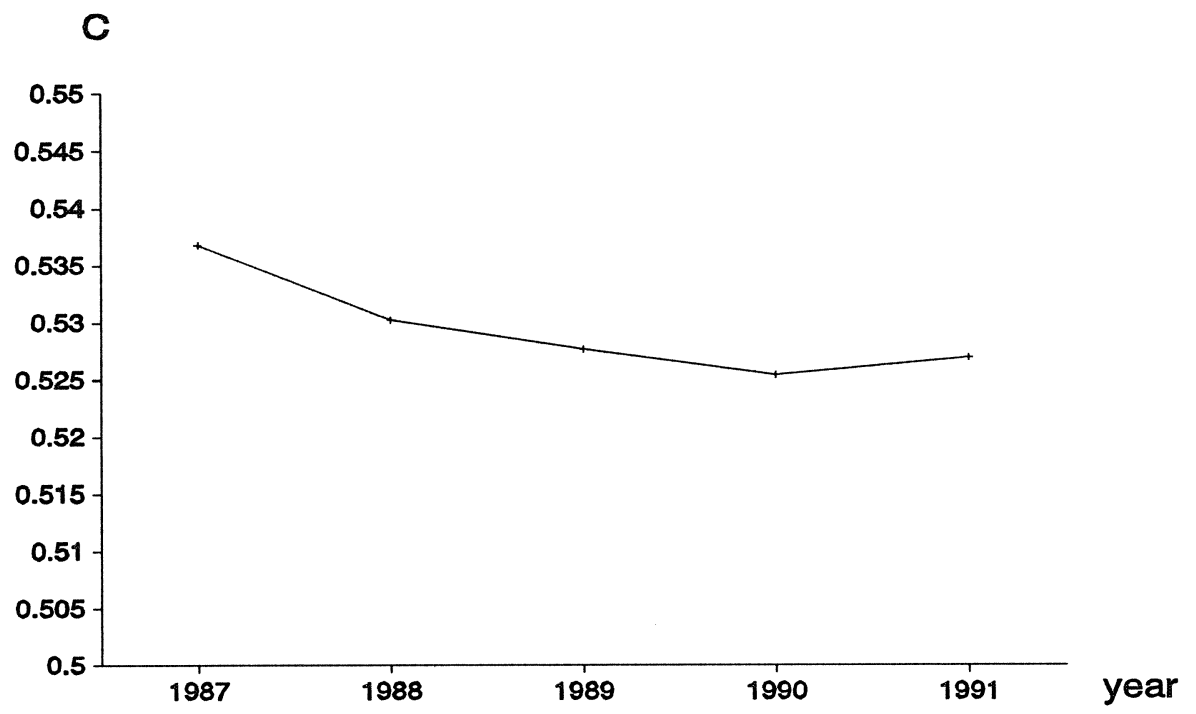

Source: EUROSTATIROA 
$-15-$

Figure 1.4. Convergency of administrative and managerial workers (2) from 1987 to 1991

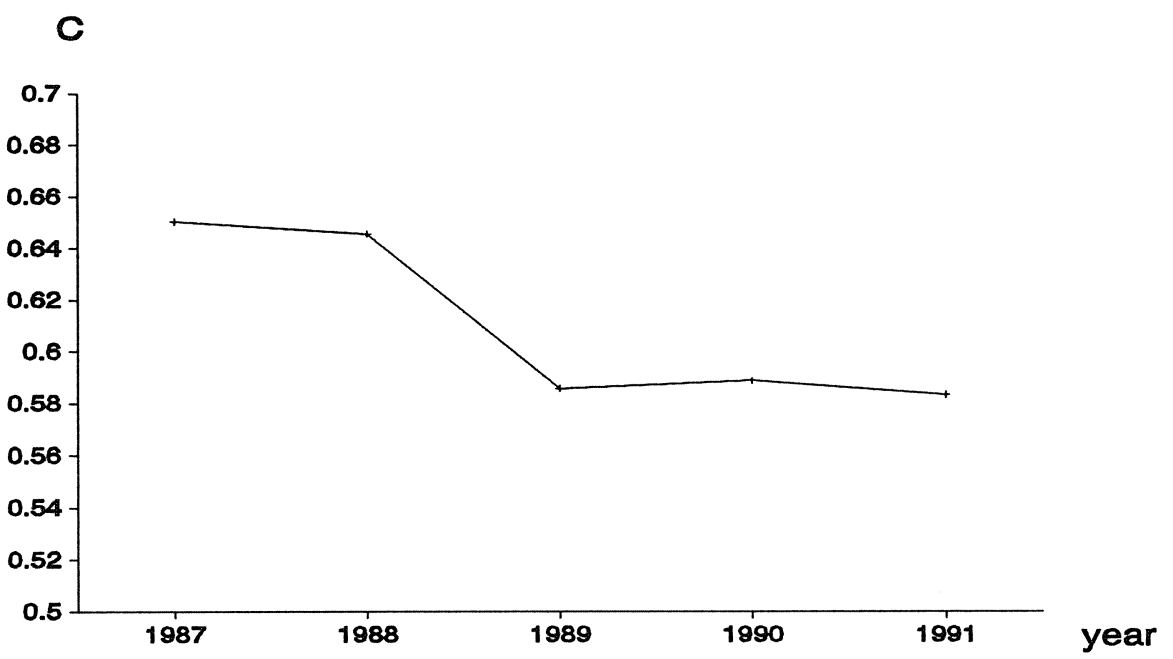

Source: EUROSTATIROA

Figure 1.5. Convergency of clerical and related workers (3) from 1987 to 1991

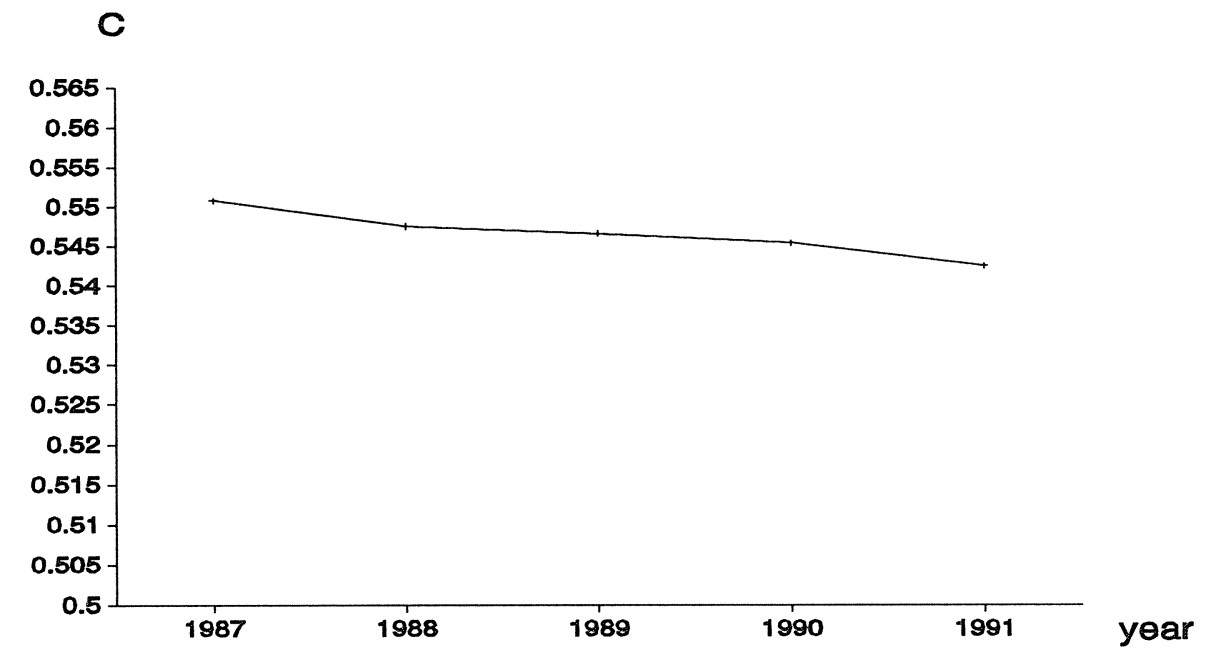

Source: EUROSTATIROA 
Figure 1.6. Convergency of sales workers (4) from 1987 to 1991

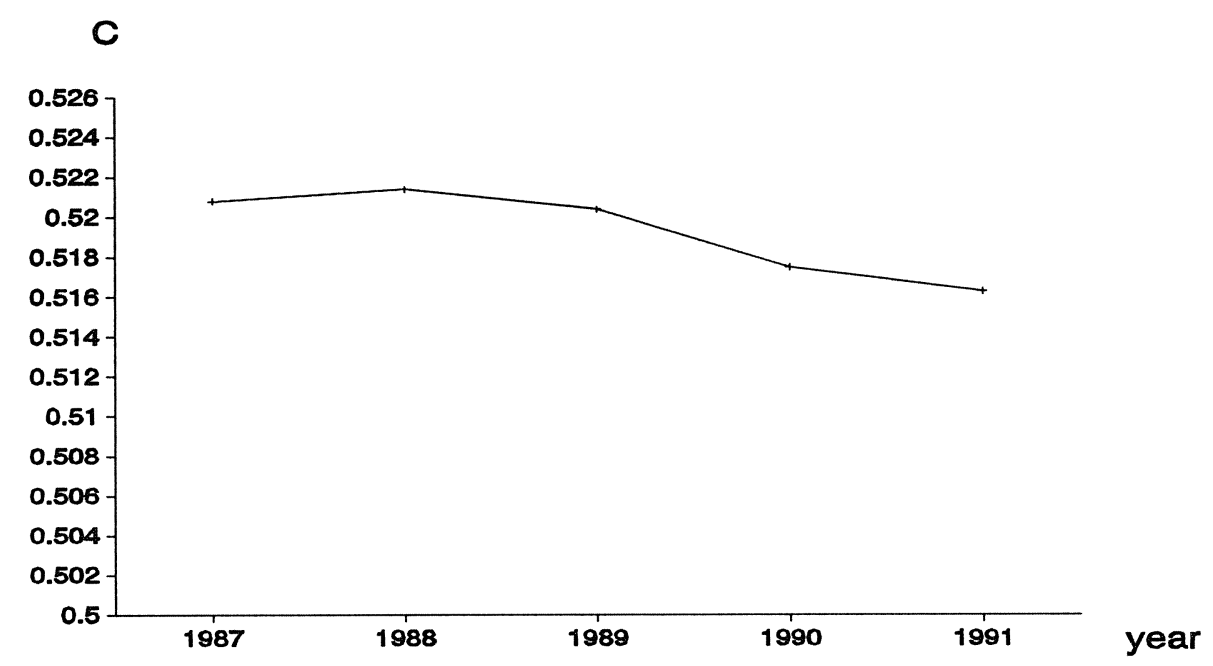

Source: EUROSTATIROA

Figure 1.7. Convergency of service workers (5) from 1987 to 1991

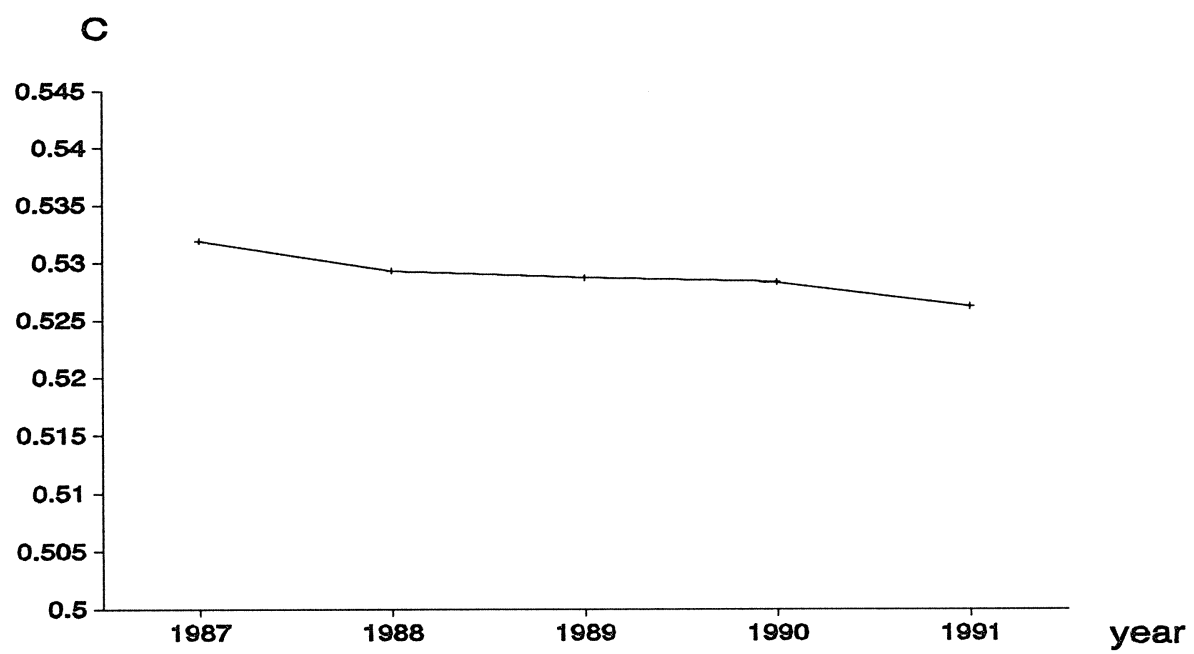

Source: EUROSTATIROA 
Figure 1.8. Convergency of agricultural, animal husbandry and forestry workers, fishermen and hunters (6) from 1987 to 1991

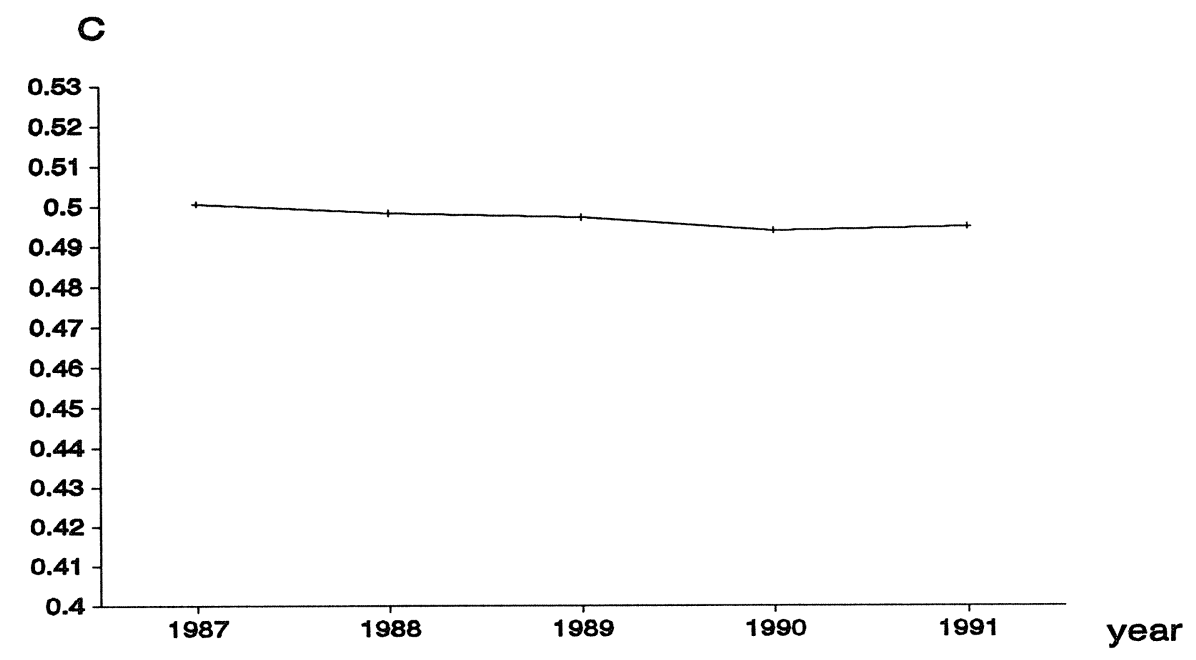

Source: EUROSTATIROA

Figure 1.9. Convergency of production and related workers, transport equipment operators and labourers (7/8/9) from 1987 to 1991

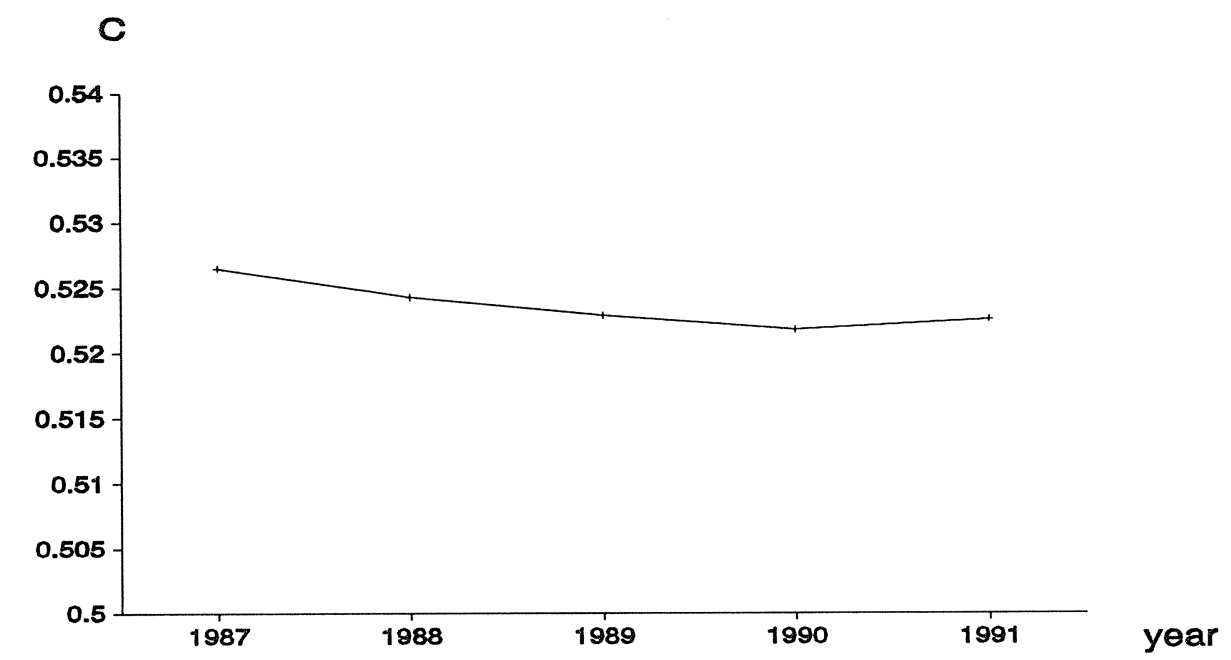

Source: EUROSTATIROA 


\section{SKILL LEVELS AND TRAINING IN THE EUROPEAN LABOUR MARKET}

\subsection{Trends in skill levels in the European Union}

The quality of the labour force is an important determinant of the position of the European Union in international competition. This makes it interesting to analyze changes in the skill level of the European working population in the various Member States. The skill level of the workforce is the result of two factors: the levels attained in initial education and training courses which may be undertaken later. Table 2.1 shows that there are great differences in the average educational levels in the various EU countries. ${ }^{8}$ The working population of the Federal Republic of Germany has the highest average level, while the Portuguese workforce shows the lowest level. Denmark and the Netherlands have a high average educational level too, while Spain and Greece also have a relatively low average educational level.

Developments in the educational level of the workforce also give an indication of skill needs due to technological change. Technological change may cause an upgrading or downgrading of the required skill level. As noted before there are two ways of upgrading the labour force. First, recruitment policies can be directed towards the selection of more highly skilled workers. Changes in the skill levels of occupational sectors offer a first indication of such upgrading processes. Training policies can be a second important instrument in upgrading the skill level of a firm's workforce. The percentage of employees who participate in additional training is therefore a second indication of upgrading of the labour force. In this chapter we will first analyze changes in the educational level of the working population of the various EU countries. In doing so we distinguish four different levels of education; the unskilled, the lower skilled, the intermediate skilled and the highly skilled workers. ${ }^{9}$ In section 2.2 the employment shares of these groups of workers in the various Member States will be analyzed, broken down by occupational sector. Then the shifts in the skill structure of employment in the period $1988^{10}$ 1991 will be analyzed, again broken down by occupational sector. Section 2.3 focuses on the participation in training of the European workforce, once more by occupational sector. Finally in section 2.4 we will draw some broad conclusions with regard to the upgrading and/or downgrading processes which appear.

8. France had to be excluded from the analysis of skill levels, as there was only data available for 1988 and 1989.

9. The unskilled are all employees who have completed only first level education or none at all. The lower skilled are those who completed educational courses at the lower level of secondary education. The intermediate skilled are those who have completed courses at the higher level of secondary education. The highly skilled are those who attended a tertiary level or higher education.

10. No data was available from before 1988 . 
Figure 2.1. Average educational level of the working population in the European Union in 1991

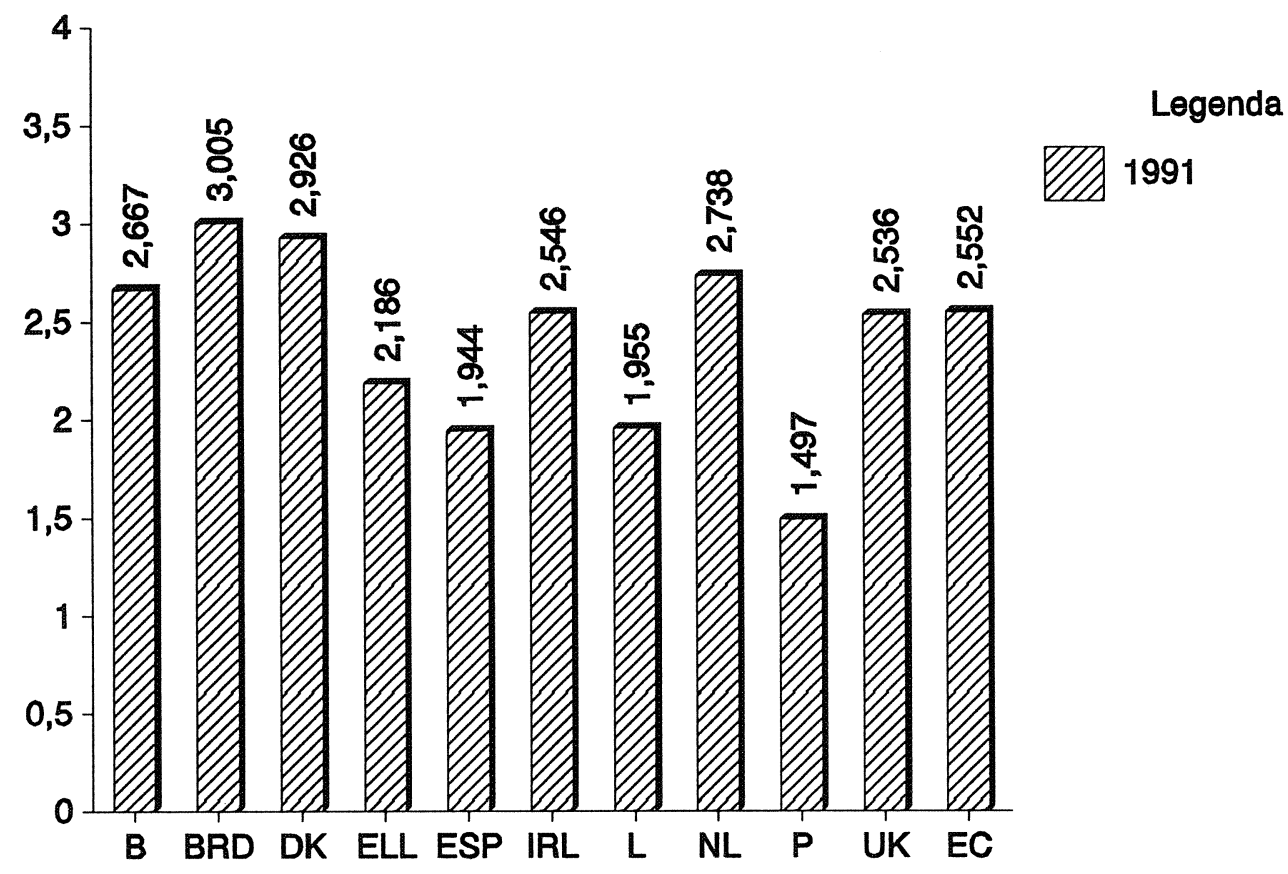

$\begin{array}{llll}1 & \text { unskilled } & 2 & \text { lower skilled } \\ 3 & \text { intermediate skilled } & 4 & \text { highly skilled }\end{array}$

Source: EUROSTAT/ROA

\subsection{The educational level of employment in the European Union}

Employment share by educational level

From table 2.1 and figure 2.1 it can be seen that the European workforce's average skill level is low to intermediate, and that the differences between the various countries of the European Union are very large. In particular the position of Portugal is exceptional. Almost three quarters of the workforce in Portugal is unskilled. It is not surprising that in this country the employment shares of the other skill levels lie far below the European averages. Other countries with a high percentage of unskilled workers are Greece and Spain. Altogether the high percentages of unskilled workers in these three countries are in line with expectations. The skill gap with the other EU countries is very large. The difference between Ireland, the country with the fourth highest percentage of unskilled workers, and Greece is almost 25 percentage points. A striking point is that the percentage of highly skilled workers in Greece is relatively high. Countries with very low percentages of unskilled workers are Denmark, the United Kingdom and the Federal Republic of Germany. In Denmark the unskilled workers did not even reach the threshold value 
of 2,500 . This corresponds with $0 \%$ unskilled. Remarkably, the percentage of lower skilled workers in the United Kingdom is very high, twice the proportion found in the Federal Republic of Germany ${ }^{11}$. The Federal Republic of Germany and Denmark are the two countries with the highest employment shares of intermediate skilled workers. This is probably an important feature in the competitive power of the economies of these two countries (see also Ryan, 1992). Finally, looking at the employment shares of highly skilled workers, Belgium comes into the picture. More than a quarter of the workforce in this country is highly skilled.

Table 2.1. Educational levels of European employment (total) in 1991

\begin{tabular}{lcccc}
\hline & unskilled & $\begin{array}{c}\text { lower } \\
\text { skilled } \\
\%\end{array}$ & $\begin{array}{c}\text { intermediate } \\
\text { skilled } \\
\%\end{array}$ & $\begin{array}{c}\text { highly } \\
\text { skilled } \\
\%\end{array}$ \\
country & $\%$ & & & 26.0 \\
\hline Belgium & 15.3 & 28.7 & 30.0 & 18.8 \\
Federal Republic of Germany & 2.1 & 14.1 & 55.9 & 20.4 \\
Denmark & - & 27.6 & 49.7 & 18.5 \\
Greece & 42.9 & 8.9 & 23.7 & 12.5 \\
Spain & 48.2 & 21.7 & 17.6 & 21.1 \\
France & 19.8 & 27.0 & 31.4 & 9.7 \\
Ireland & 37.2 & 38.6 & 13.3 & 21.3 \\
Luxembourg & 11.1 & 25.6 & 41.8 & 7.8 \\
Netherlands & 72.5 & 12.2 & 7.1 & 16.0 \\
Portugal \\
United Kingdom & 0.1 & 60.5 & 20.0 & 17.1 \\
European Union & 15.1 & 29.6 & 33.9 & \\
\hline
\end{tabular}

Source: EUROSTAT/ROA

Table 2.2 gives an impression of the educational level of 'professional, technical and related workers'. It is clear that the average employee in this occupational sector is highly educated. Most remarkably, Greece has the highest percentage of high skilled workers in this occupational sector. The situation gets even more peculiar, as we see that Spain and Portugal also have high percentages of highly skilled workers, whereas the Federal Republic of Germany and Denmark have relatively low percentages of highly skilled workers in this occupational sector. Moreover, the countries that have the lowest percentages of highly skilled workers have the highest percentages of intermediate skilled workers. One could almost believe in the existence of an inverse relation between the average educational level of the workforce, as presented in table 2.1 , and the educational level of the highly skilled occupational sector of 'professional, technical and related workers'. Table 1.1 shows that the employment share of this occupational sector was relatively low in the three countries with the lowest skill levels: Greece, Spain and Portugal. This indicates that as the occupational sector of 'professional, technical and related workers' starts to develop it offers highly skilled employment, and as the sector expands the

11. This large group of lower skilled workers has been the result of placing the group of O-levels in this category, which is in contrast with OECD reports. 
percentage of less skilled employment starts to rise. According to Bartel \& Lichtenberg (1987) this could indicate learning processes with respect to the use of new technologies. However, Belgium seems to be the exception to this rule, as Belgium has both a high skill level and a high employment share in this occupational sector.

Table 2.2. Skill levels of professional, technical and related workers (O/1) in 1991

\begin{tabular}{lcccc}
\hline & unskilled & $\begin{array}{c}\text { lower } \\
\text { skilled } \\
\%\end{array}$ & $\begin{array}{c}\text { intermediate } \\
\text { skilled } \\
\%\end{array}$ & $\begin{array}{c}\text { highly } \\
\text { skilled } \\
\%\end{array}$ \\
country & $\%$ & 4.8 & 18.8 & 75.0 \\
\hline Belgium & 1.5 & 3.2 & 31.9 & 55.0 \\
Federal Republic of Germany & 0.3 & 12.6 & 32.4 & 54.5 \\
Denmark & - & 2.1 & 10.1 & 83.0 \\
Greece & 3.4 & 5.2 & 15.4 & 75.2 \\
Spain & 4.2 & 5.1 & 17.9 & 75.1 \\
France & - & 19.2 & 28.1 & 50.7 \\
Ireland & - & 5.1 & 34.6 & 59.3 \\
Luxembourg & 0.8 & 10.4 & 14.0 & 66.7 \\
Netherlands & 7.9 & 23.0 & 17.8 & 57.4 \\
Portugal \\
United Kingdom & - & 10.0 & 24.5 & 60.6 \\
European Union & 1.0 & & & \\
\hline
\end{tabular}

Source: EUROSTAT/ROA

The skill levels of 'administrative and managerial workers' are shown in table 2.3. In all countries the majority of the workers are skilled at an intermediate or higher level. However once more Portugal in particular, and to a lesser degree also Greece and Spain, have relatively high percentages of unskilled employment. The United Kingdom again shows a relatively high percentage of lower skilled employment and the Federal Republic of Germany and Denmark again have relatively high percentages of intermediate skilled workers. In comparison to the previous table, the differences between the countries are much smaller. The employment share of highly skilled 'administrative and managerial workers' is much lower than that of highly skilled 'professional, technical and related workers'. However, the percentages of highly skilled employment are in line with expectations. In this table Greece seems to be the exception to the rule with a relatively high percentage of highly skilled workers. The 'high income' countries have in general the highest percentages and the 'lower income' countries the lowest percentages. 
Table 2.3. Skill levels of administrative and managerial workers (2) in 1991

\begin{tabular}{lcccc}
\hline & unskilled & $\begin{array}{c}\text { lower } \\
\text { skilled } \\
\%\end{array}$ & $\begin{array}{c}\text { intermediate } \\
\text { skilled } \\
\%\end{array}$ & $\begin{array}{c}\text { highly } \\
\text { skilled } \\
\%\end{array}$ \\
country & $\%$ & & & \\
\hline & & 19.0 & 35.3 & 38.3 \\
Belgium & 7.4 & 2.8 & 45.2 & 43.7 \\
Federal Republic of Germany & 0.4 & 12.1 & 53.1 & 32.1 \\
Denmark & - & 6.1 & 29.1 & 45.5 \\
Greece & 17.3 & 14.5 & 26.7 & 32.5 \\
Spain & 26.3 & 11.4 & 38.7 & 44.3 \\
France & & - & - & 62.5 \\
Ireland & - & 9.9 & 41.9 & 44.1 \\
Luxembourg & - & 19.0 & 12.4 & 22.7 \\
Netherlands & 4.0 & 44.8 & 23.8 & 29.6 \\
Portugal & 45.5 & 22.4 & 33.7 & 36.2 \\
United Kingdom & - & & & \\
European Union & 4.4 & & & \\
\hline
\end{tabular}

Source: EUROSTAT/ROA

The skill level of 'clerical and related workers' in various Member States of the European Union is characterized by the high proportions of intermediate skilled employment. Almost half of all people employed in this occupational sector has an intermediate skill level. The countries with the highest percentages of intermediate skilled employment are the Federal Republic of Germany, Denmark, Ireland and, surprisingly, Greece. In this occupational sector Greece has the highest average educational level. For the United Kingdom it can again be seen that the employment share of lower skilled workers is extremely high.

Table 2.4. Skill levels of clerical and related workers (3) in 1991

\begin{tabular}{lcccc}
\hline & unskilled & $\begin{array}{c}\text { lower } \\
\text { skilled } \\
\%\end{array}$ & $\begin{array}{c}\text { intermediate } \\
\text { skilled } \\
\%\end{array}$ & $\begin{array}{c}\text { highly } \\
\text { skilled } \\
\%\end{array}$ \\
country & $\%$ & & & 20.9 \\
\hline Belgium & 5.5 & 25.4 & 48.2 & 10.3 \\
Federal Republic of Germany & 0.7 & 10.3 & 69.3 & 12.1 \\
Denmark & - & 19.0 & 68.6 & 23.4 \\
Greece & 7.3 & 5.2 & 61.7 & 14.7 \\
Spain & 16.8 & 24.0 & 44.4 & 15.2 \\
France & & 16.0 & 62.5 & 8.6 \\
Ireland & 6.1 & 52.5 & 29.6 & 15.1 \\
Luxembourg & 9.1 & 26.2 & 52.5 & 3.7 \\
Netherlands & 6.0 & 36.7 & 23.6 & 6.3 \\
Portugal \\
United Kingdom & 35.6 & 70.9 & 18.9 & 10.7 \\
European Union & - & 32.6 & 47.5 & \\
\hline
\end{tabular}


In table 2.5 the skill level of sales workers is presented. Again Greece, Spain and Portugal show relatively high percentages of unskilled employment, whereas the in the United Kingdom the majority of 'sales workers' fall in the lower skilled category. The Federal Republic of Germany and Denmark show high percentages of intermediate skilled employment. Finally in Belgium relatively many highly skilled workers are employed in this occupational sector.

Table 2.5. Skill levels of sales workers (4) in 1991

\begin{tabular}{lcccc}
\hline & unskilled & $\begin{array}{c}\text { lower } \\
\text { skilled } \\
\%\end{array}$ & $\begin{array}{c}\text { intermediate } \\
\text { skilled } \\
\%\end{array}$ & $\begin{array}{c}\text { highly } \\
\text { skilled } \\
\%\end{array}$ \\
country & $\%$ & 30.9 & 36.5 & 19.2 \\
\hline Belgium & 13.4 & 11.4 & 68.1 & 9.1 \\
Federal Republic of Germany & 0.8 & 25.5 & 64.7 & 6.9 \\
Denmark & - & 11.5 & 40.1 & 10.7 \\
Greece & 33.8 & 28.0 & 19.2 & 5.4 \\
Spain & 47.4 & - & - & 11.7 \\
France & - & 31.6 & 44.4 & 4.3 \\
Ireland & 11.8 & 48.6 & 11.4 & 8.5 \\
Luxembourg & 34.3 & 32.1 & 44.9 & 2.1 \\
Netherlands & 14.4 & 19.8 & 8.8 & 8.2 \\
Portugal & 69.0 & 69.5 & 17.4 & 8.3 \\
United Kingdom & - & 34.6 & 37.6 & \\
European Union & 14.7 & & & \\
\hline
\end{tabular}

Source: EUROSTAT/ROA

Table 2.6. Skill levels of service workers (5) in 1991

\begin{tabular}{lcccc}
\hline & unskilled & $\begin{array}{c}\text { lower } \\
\text { skilled } \\
\%\end{array}$ & $\begin{array}{c}\text { intermediate } \\
\text { skilled } \\
\%\end{array}$ & $\begin{array}{c}\text { highly } \\
\text { skilled } \\
\%\end{array}$ \\
country & $\%$ & & & \\
\hline & & 37.6 & 29.0 & 4.6 \\
Belgium & 28.8 & 25.6 & 53.1 & 7.6 \\
Federal Republic of Germany & 4.0 & 47.4 & 42.9 & 5.4 \\
Denmark & - & 11.7 & 24.7 & 1.9 \\
Greece & 51.0 & 25.7 & 12.6 & 9.4 \\
Spain & 59.8 & 31.0 & 33.0 & - \\
France & & 31.1 & 4.6 & 3.6 \\
Ireland & 26.3 & 34.7 & 43.0 & 0.5 \\
Luxembourg & 63.5 & 8.8 & 3.1 & 4.3 \\
Netherlands & 18.5 & 72.8 & 16.4 & 4.7 \\
Portugal & 87.4 & 41.2 & 28.4 & \\
United Kingdom & 0.3 & & & \\
European Union & 20.8 & & & \\
\hline
\end{tabular}

Source: EUROSTAT/ROA 
The profile of the 'service workers' in table 2.6 shows a characteristically high percentage of lower skilled employment in most EU countries. It is again the United Kingdom that has the highest percentage of lower skilled employment, whereas in the Southern European Member States the majority of the workers are unskilled.

From table 2.7 it can be seen that the skill levels of 'agricultural, animal husbandry and forestry workers, fishermen and hunters' are on average very low. The modal worker in this occupational sector is unskilled. In Portugal the percentage of unskilled employment even approaches $100 \%$. However, in three countries the skill level is much higher. These countries are the Federal Republic of Germany, Denmark and the Netherlands. This higher skill level can probably be explained by differences in production technologies.

Table 2.7. Skill levels of agricultural, animal husbandry and forestry workers, fishermen and hunters (6) in 1991

\begin{tabular}{|c|c|c|c|c|}
\hline country & $\begin{array}{c}\text { unskilled } \\
\text { \% }\end{array}$ & $\begin{array}{l}\text { lower } \\
\text { skilled } \\
\%\end{array}$ & $\begin{array}{l}\text { intermediate } \\
\text { skilled } \\
\quad \%\end{array}$ & $\begin{array}{c}\text { highly } \\
\text { skilled } \\
\%\end{array}$ \\
\hline Belgium & 36.0 & 40.9 & 19.5 & 3.5 \\
\hline Federal Republic of Germany & 2.2 & 31.1 & 46.3 & 12.0 \\
\hline Denmark & - & 49.6 & 44.8 & 3.8 \\
\hline Greece & 74.2 & 5.6 & 5.3 & 0.8 \\
\hline Spain & 82.3 & 13.2 & 3.8 & 0.7 \\
\hline \multicolumn{5}{|l|}{ France } \\
\hline Ireland & 48.0 & 28.9 & 16.8 & 6.2 \\
\hline Luxembourg & 56.7 & 41.8 & - & - \\
\hline Netherlands & 16.0 & 40.0 & 41.6 & 2.4 \\
\hline Portugal & 97.8 & 1.5 & 0.6 & - \\
\hline United Kingdom & - & 75.9 & 17.2 & 3.6 \\
\hline European Union & 51.4 & 23.6 & 17.2 & 3.5 \\
\hline
\end{tabular}

Source: EUROSTAT/ROA

Table 2.8 describes the skill levels of 'production and related workers, equipment operators and labourers'. As we saw in chapter 1, about one third of the working population in the European Union is employed in this occupational sector. The table is in line with expectations, as the workforce in the 'higher income' countries is on average higher skilled than in the 'lower income' countries. The table again shows an extremely high percentage of unskilled workers in Portugal. More than $90 \%$ of the workforce in Portugal is unskilled, whereas the average European worker is educated at the lower to intermediate level. Spain and Greece also have relatively high employment shares for unskilled workers. The Federal Republic of Germany and Denmark can again be seen to have high employment shares for intermediate skilled workers, whereas in the United Kingdom most workers are in the 'lower skilled' group. 
Table 2.8. Skill levels of production and related workers, transport equipment operators and labourers $(7 / 8 / 9)$ in 1991

\begin{tabular}{|c|c|c|c|c|}
\hline country & $\begin{array}{c}\text { unskilled } \\
\%\end{array}$ & $\begin{array}{l}\text { lower } \\
\text { skilled } \\
\%\end{array}$ & $\begin{array}{l}\text { intermediate } \\
\text { skilled } \\
\quad \%\end{array}$ & $\begin{array}{l}\text { highly } \\
\text { skilled } \\
\%\end{array}$ \\
\hline Belgium & 26.8 & 44.8 & 25.1 & 3.3 \\
\hline Federal Republic of Germany & 3.8 & 19.1 & 59.9 & 8.7 \\
\hline Denmark & - & 38.6 & 52.4 & 4.8 \\
\hline Greece & 54.7 & 13.9 & 20.3 & 6.2 \\
\hline Spain & 60.1 & 25.2 & 13.5 & 1.1 \\
\hline France & - & - & & - \\
\hline Ireland & 28.8 & 43.3 & 22.2 & 5.5 \\
\hline Luxembourg & 62.0 & 36.3 & 1.1 & - \\
\hline Netherlands & 20.3 & 38.4 & 38.7 & 2.5 \\
\hline Portugal & 90.3 & 6.6 & 2.4 & 0.3 \\
\hline United Kingdom & 0.2 & 69.6 & 24.2 & 3.3 \\
\hline European Union & 21.8 & 34.5 & 35.0 & 4.8 \\
\hline
\end{tabular}

Source: EUROSTAT/ROA

\section{Changes in skill levels}

To get an indication of the dynamics in the skill levels in the EU Member States, the changes in the employment shares of the various skill groups will be analyzed. ${ }^{12}$ Table 2.9 shows the shifts in the employment shares of unskilled workers. On average the employment share of unskilled workers decreased by 1.9 percentage points in the period 1988-1991. The greatest decrease occurred in the occupational sector of 'agricultural, animal husbandry and forestry workers, fishermen and hunters', in which the employment share of unskilled workers decreased by 2.1 percentage points. Keeping table 1.3 in mind, it can be said that the strong decrease in the employment share of this occupational sector was mainly at the expense of the unskilled workers. Remarkably, the Federal Republic of Germany has been the only country in European Union in which the employment share of unskilled workers has slightly increased. The most striking development is the large decrease in the employment shares of unskilled workers in Greece, Spain, Ireland and Portugal. This is a very strong indication that these countries are catching up with the rest of the European Union. Portugal and Belgium also show strong decreases in the employment share of unskilled workers. Very surprising at the occupational level is that the employment share of unskilled 'administrative and managerial workers' has risen, even though the employment share of this occupational sector in Portugal decreased by 12.4 percentage points.

12. There was no data available for the Netherlands for 1988 and 1989 , so the Netherlands had to be excluded from this analysis. 
Table 2.9. Change, in percentage points, in the employment shares of unskilled workers by occupational sector in the period 1988-1991

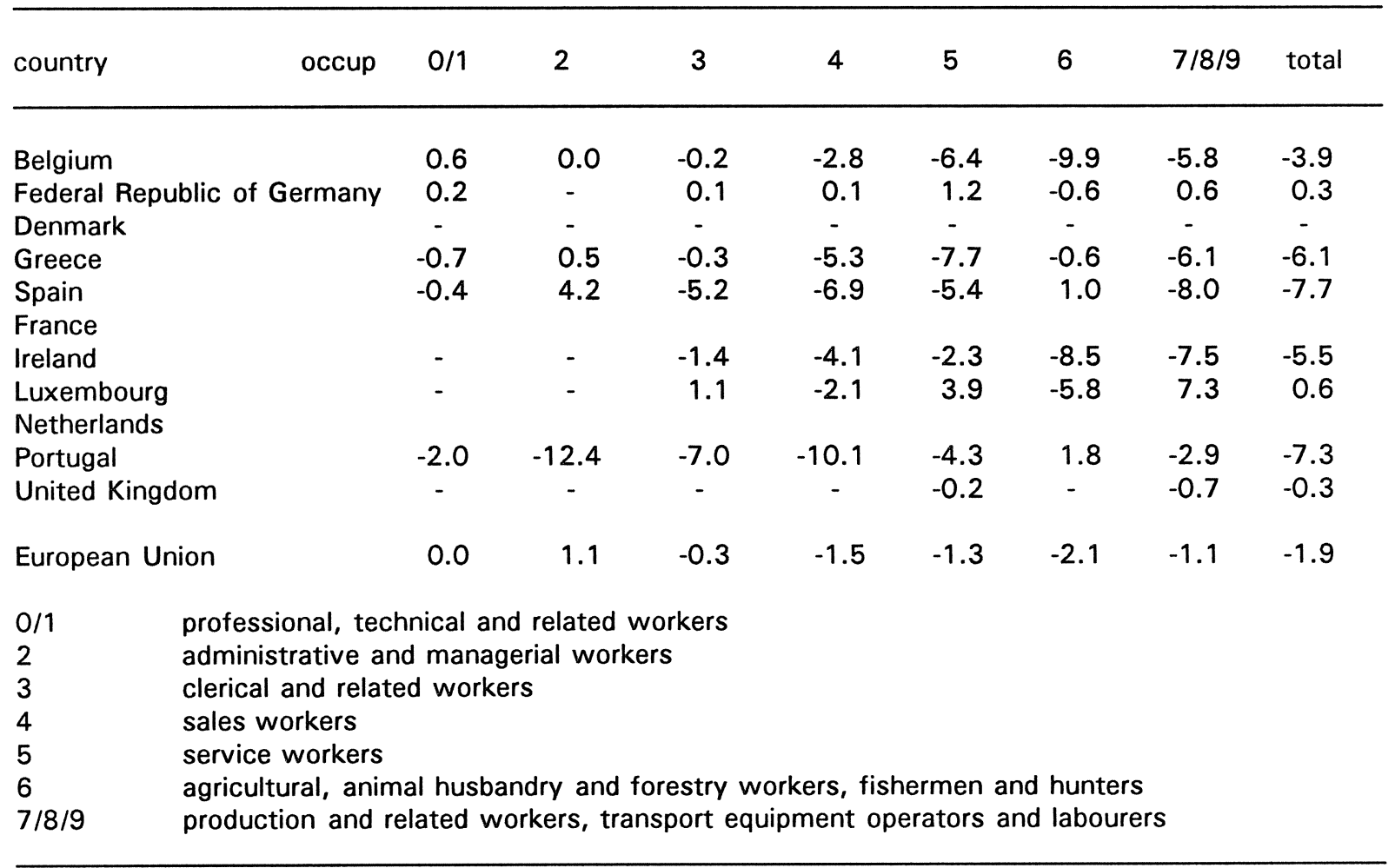

Source: EUROSTAT/ROA

In the period 1988-1991 the employment share of lower skilled workers showed the greatest decrease. The total employment share of lower skilled workers decreased by 7.4 percentage points. The table also shows that in the Federal Republic of Germany the upgrading process is most prominent, as this country shows the greatest decrease in the employment share, by 15.9 percentage points, which is far ahead of the next highest drop of 3.8 points in the United Kingdom. However, in Greece, Spain, Ireland and Portugal employment for lower skilled workers increased. In these countries we can see an upgrading process from unskilled to lower skilled employment. For 'clerical and related workers' the employment share of lower skilled workers generally decreased. Although in the Federal Republic of Germany the employment share of lower skilled 'agricultural, animal husbandry and forestry workers, fishermen and hunters' decreased by 19.3 percentage points, ${ }^{13}$ for Europe as a whole lower skilled workers in this occupational sector suffered the least decrease in their employment share.

Given the preceding tables it is not surprising that the employment share of intermediate skilled workers has increased considerably. The total employment share of intermediate skilled workers in the EU increased by 6.4 percentage points. This indicates an upgrading process from lower skilled to intermediate skilled employment. The Federal Republic of Germany shows the greatest

13. One should remember that the total share of 'agricultural, animal husbandry and forestry workers, fishermen and hunters' in Germany is only $3.5 \%$ and has decreased strongly in the previous years. 
increase in the employment share of intermediate skilled workers, by 11.6 percentage points. Combined with the fall in employment share for lower skilled workers of 15.9 points (table 2.10), this shows a marked upgrading process. Though the European average employment share of intermediate skilled workers increased by 6.4 percentage points, in Denmark and Ireland their employment share hardly changed. In Denmark the employment share of intermediate skilled workers only increased for 'service workers' and for 'agricultural, animal husbandry and forestry workers, fishermen and hunters'. In all other occupational sectors in Denmark the employment share of intermediate skilled workers decreased. The employment share of intermediate skilled 'agricultural, animal husbandry and forestry workers, fishermen and hunters' increased in all EU countries. This is the only occupational sector in which this occurred. The highest increases in employment shares in the analyzed EU countries were for 'service workers' and 'clerical workers', whereas the smallest increases have been for 'professional, technical and related workers' and 'administrative and managerial workers'.

Table 2.10. Change, in percentage points, in the employment shares of lower skilled workers by occupational sector in the period 1988-1991

\begin{tabular}{|c|c|c|c|c|c|c|c|c|c|}
\hline countr & occup & $0 / 1$ & 2 & 3 & 4 & 5 & 6 & $7 / 8 / 9$ & total \\
\hline \multicolumn{2}{|c|}{ Belgium } & -1.5 & 1.0 & -3.3 & -6.9 & 0.8 & 6.4 & 0.5 & -2.3 \\
\hline \multicolumn{2}{|c|}{ Federal Republic of Germany } & -7.4 & -7.5 & -16.9 & -17.3 & -16.4 & -19.3 & -17.9 & -15.9 \\
\hline \multicolumn{2}{|c|}{ Denmark } & -3.3 & 0.3 & 0.6 & -3.4 & -9.2 & -11.6 & -2.5 & -3.5 \\
\hline \multicolumn{2}{|c|}{ Greece } & 0.0 & 1.0 & 0.5 & -0.4 & 1.6 & 1.9 & 0.4 & 0.8 \\
\hline \multicolumn{2}{|c|}{ Spain } & 0.1 & -2.1 & -1.1 & 3.9 & 2.8 & 1.9 & 5.1 & 2.9 \\
\hline \multicolumn{10}{|c|}{ France } \\
\hline \multicolumn{2}{|c|}{ Ireland } & -0.1 & 0.0 & -1.2 & 0.9 & 1.0 & 5.1 & 5.5 & 2.1 \\
\hline \multicolumn{2}{|c|}{ Luxembourg } & 3.7 & - & 1.8 & 3.9 & 3.1 & 6.1 & 0.0 & 1.9 \\
\hline \multicolumn{10}{|c|}{ Netherlands } \\
\hline \multicolumn{2}{|c|}{ Portugal } & 0.9 & 6.4 & 3.3 & 7.3 & 3.0 & 0.6 & 1.6 & 3.1 \\
\hline \multicolumn{2}{|c|}{ United Kingdom } & 1.6 & -2.1 & -5.9 & -3.5 & -5.7 & 0.6 & -3.0 & -3.8 \\
\hline \multicolumn{2}{|c|}{ European Union } & -3.4 & -7.9 & -10.7 & -7.4 & -7.5 & -2.5 & -7.4 & -7.4 \\
\hline $0 / 1$ & \multicolumn{9}{|c|}{ professional, technical and related workers } \\
\hline 2 & \multicolumn{9}{|c|}{ administrative and managerial workers } \\
\hline 3 & \multicolumn{9}{|c|}{ clerical and related workers } \\
\hline 4 & \multicolumn{9}{|c|}{ sales workers } \\
\hline 5 & \multicolumn{9}{|l|}{ service workers } \\
\hline 6 & \multicolumn{9}{|c|}{ agricultural, animal husbandry and forestry workers, fishermen and hunters } \\
\hline $7 / 8 / 9$ & \multicolumn{9}{|c|}{ production and related workers, transport equipment operators and labourers } \\
\hline
\end{tabular}

Source: EUROSTAT/ROA 
Table 2.11. Change, in percentage points, in the employment shares of intermediate skilled workers by occupational sector in the period 1988-1991

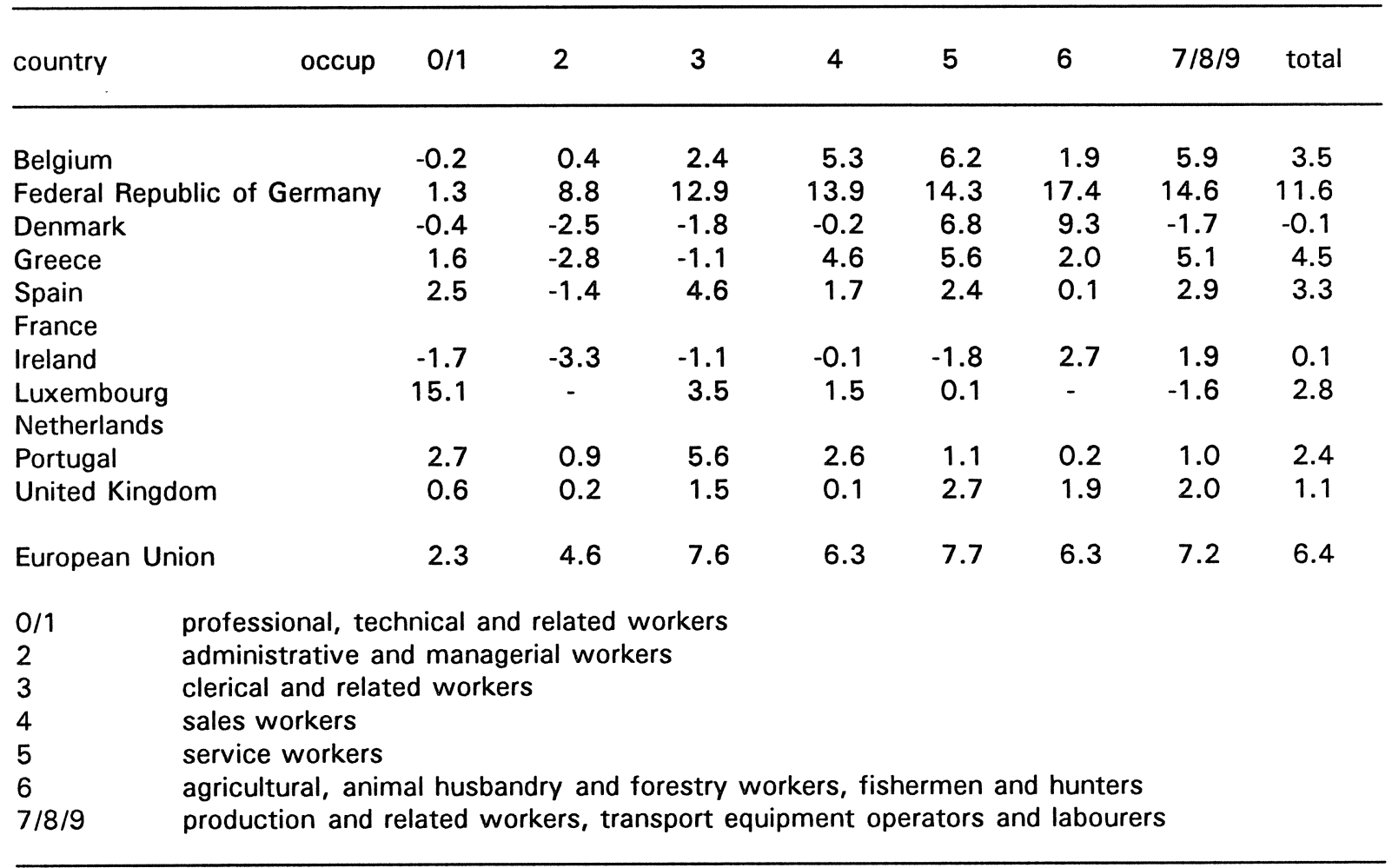

Source: EUROSTAT/ROA

Finally in table 2.12 the changes in the employment shares of the highly skilled workers in the European Union are shown. The total employment share of highly skilled workers increased by 1.7 percentage points in the period 1988-1991, showing a general upgrading tendency. Belgium, the Federal Republic of Germany and Ireland show the largest increases of the employment share of highly skilled workers. Remarkably, the United Kingdom shows only a small decrease in the employment share of the highly skilled. However, what is most striking in this table is the overall decrease in the employment share of highly skilled 'professional, technical and related workers'. From table 2.2 we saw that the highly skilled workers had an employment share in this occupational sector of more than $60 \%$. A decrease in employment share of highly skilled workers means a great loss of employment in this occupational sector, especially when we could see in figure 1.1 that this occupational sector showed the highest growth rates in both 1983-1987 and 1987-1991. This means that intermediate skilled workers must have benefited most from the employment growth in this occupational sector, as it was the only skill level for which the employment share increased. On balance this indicates a downgrading tendency in the level of employment. For highly skilled 'administrative and managerial workers' the increase in the employment share of highly skilled workers was the highest. Remarkably, in the various EU countries some opposing trends can be observed in this occupational sector. Most countries show an upgrading tendency in this occupational sector, but in Belgium, Denmark and Spain the employment shares of highly skilled workers decreased. 
Table 2.12. Change, in percentage points, in the employment shares of highly skilled workers by occupational sector in the period 1988-1991

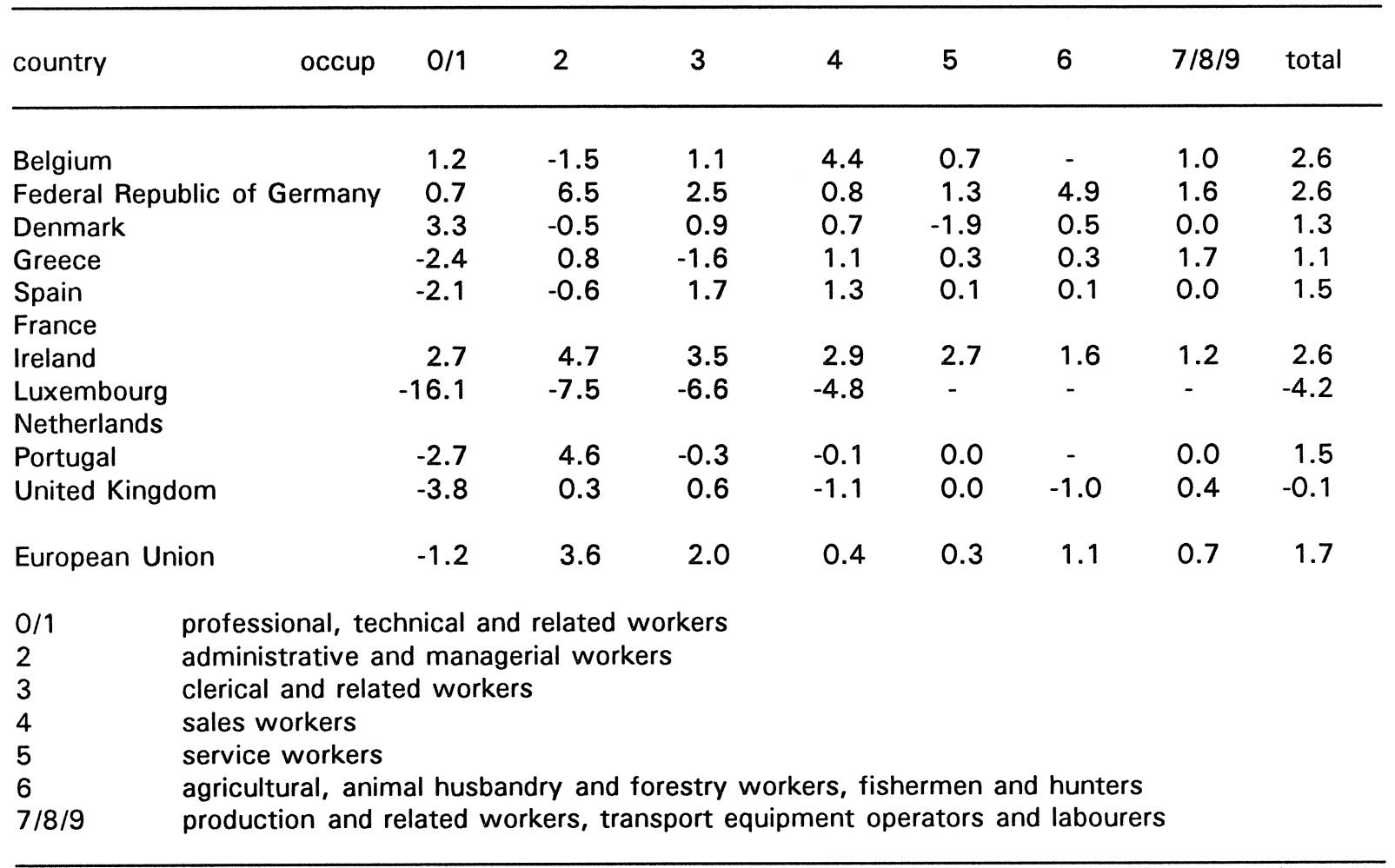

Source: EUROSTAT/ROA

\subsection{Participation in training in the European Union}

Participation in training is a good indication of the upgrading of employment by means of training policies. ${ }^{14}$ From table 2.13 it can be seen that especially in Denmark, the Netherlands and the United Kingdom, participation in training is of great importance. Bearing in mind the lower skill level of employment in the United Kingdom, as shown in the preceding section, it can be expected that in upgrading the skill level of the labour force in this country training policies will be most important. The low skill level may be compensated for by more intensive participation in training. For the Netherlands and Denmark both training policies and recruitment policies must have been very important. These countries combine a relatively highly skilled labour force with a high participation in training activities. For the other EU countries the recruitment of more highly skilled workers is probably more important than training policies. All these countries show participation rates in training below the average EU percentage. From table 2.13 it can also be seen that the importance of participation in training strongly increased

14. Participation in training refers to all kinds of training related to economic activity. This means that attending a school which provides training in specific subjects, in-company training, 'dual' training forms (a combination of vocational education and in-plant training) and apprenticeships are included. This can lead to double-counting, where some training which leads to a formal qualification is measured once as increasing the educational level of the workers, and again as participation in training. 
in the Netherlands and the United Kingdom in the period 1987-1991. The participation in training in these two countries increased by respectively 2 and 2.9 percentage points, which are the highest increases in the European Union. For Belgium and the Federal Republic of Germany the importance of training has, surprisingly, slightly diminished, as training participation rates in these two countries fell by 0.4 and 0.8 percentage points respectively.

Table 2.13. Participation in training in the European Union (total) in 1991 and \%-points change in the period 1987-1991

\begin{tabular}{lcc}
\hline country & $\begin{array}{c}1991 \\
\text { participation } \\
\%\end{array}$ & $\begin{array}{c}1987-1991 \\
\text { \%-points change }\end{array}$ \\
\hline Belgium & 2.4 & -0.4 \\
Federal Republic of Germany & 9.0 & -0.8 \\
Denmark & 22.7 & 0.7 \\
Greece & 1.3 & 0.0 \\
Spain & 3.0 & 0.3 \\
France & 4.2 & 0.0 \\
Ireland & 7.2 & 0.9 \\
Luxembourg & 4.6 & 0.6 \\
Netherlands & 21.2 & 2.0 \\
Portugal & 3.6 & 0.9 \\
United Kingdom & 16.3 & 2.9 \\
European Union & & 0.6 \\
\hline
\end{tabular}

Source: EUROSTAT/ROA

'Professional, technical and related workers' participate most in training, as can be seen in table 2.14. On average in $199114.2 \%$ of all 'professional, technical and related workers' in Europe participated in training. In this occupational sector the United Kingdom leads the ranking with a training participation rate of $26.6 \%$. All countries of the European Union show a relatively high participation in training for this occupational sector, compared to their average participation rates. In accordance with the general picture shown in table 2.13, Denmark, the Netherlands and the United Kingdom show the highest training participation rates, while the other EU members show much lower participation rates. Only the Federal Republic of Germany shows a participation rate close to the European average. This general pattern also applies to the other occupational sectors, as shown in tables 2.15 to 2.20. There are however great differences between the various occupational sectors. As noted, 'professional, technical and related workers' participate most in training, whereas 'agricultural, animal husbandry and forestry workers, fishermen and hunters' (table 2.19) hardly participate in training at all. Participation in training is also very low for 'production and related workers, transport equipment operators and labourers'. The other occupational sectors show percentages slightly above the total European average. Except for 'agricultural, animal husbandry and forestry workers, fishermen and hunters' and 'production and related workers, transport equipment operators and labourers', rates of participation in the European Union have risen. Remarkably, within all occupational sectors opposing trends can be observed. 
Table 2.14. Participation in training by professional, technical and related workers $(0 / 1)$ in 1991 and \%points change in the period 1987-1991

\begin{tabular}{lcc}
\hline & $\begin{array}{c}1991 \\
\text { participation } \\
\text { country }\end{array}$ & $\begin{array}{c}\text { 1987-1991 } \\
\text { \%-points change }\end{array}$ \\
& & \\
\hline & 3.7 & -0.2 \\
Belgium & 10.5 & 0.2 \\
Federal Republic of Germany & 23.3 & 1.0 \\
Denmark & 2.9 & 0.1 \\
Greece & 6.5 & -0.9 \\
Spain & 7.9 & -0.4 \\
France & 12.9 & 1.6 \\
Ireland & 5.9 & -0.3 \\
Luxembourg & 23.1 & -0.5 \\
Netherlands & 8.2 & 2.7 \\
Portugal & 26.6 & 3.6 \\
United Kingdom & 14.2 & 0.6 \\
European Union & & \\
\hline
\end{tabular}

Source: EUROSTAT/ROA

Table 2.15. Participation in training by administrative and managerial workers (2) in 1991 and \%-points change in the period 1987-1991

\begin{tabular}{lcc}
\hline country & $\begin{array}{c}1991 \\
\text { participation } \\
\%\end{array}$ & $\begin{array}{c}\text { 1987-1991 } \\
\text { \%-points change }\end{array}$ \\
\hline Belgium & 1.9 & -1.1 \\
Federal Republic of Germany & 4.9 & 0.0 \\
Denmark & 17.4 & 5.5 \\
Greece & 2.2 & 1.2 \\
Spain & 1.9 & 0.0 \\
France & 2.4 & 0.5 \\
Ireland & 5.8 & 1.0 \\
Luxembourg & - & - \\
Netherlands & 13.9 & 2.2 \\
Portugal & 1.3 & -0.1 \\
United Kingdom & 14.8 & 2.6 \\
European Union & 9.4 & 0.9 \\
\hline
\end{tabular}

Source: EUROSTAT/ROA

Most striking in table 2.14 is that the participation in training of Dutch 'professional, technical and related workers' decreased by 0.5 percentage points, whereas the participation rate of Portugal increased by 2.7 points in this occupational sector. In tables 2.15 and 2.19 very high increases in participation for 'administrative and managerial workers' and 'agricultural, animal husbandry and forestry workers, fishermen and hunters' can be observed for Denmark, of 5.5 percentage points and 5.7 percentage points respectively. Remarkably tables 2.17 and 2.18 show that the participation in training of 'sales workers' and of 'service workers' increased in 
the Netherlands by 5.5 percentage points and 4.3 percentage points respectively, while in the Federal Republic of Germany the rates decreased by 2 and 1.9 percentage points respectively. Finally, the occupational sector of 'production and related workers, transport equipment operators and labourers' is the only sector that shows an average decrease in the participation rate. However, as said before, the various EU countries in this occupational sector show opposing trends.

Table 2.16. Participation in training by clerical and related workers (3) in 1991 and \%-points change in the period 1987-1991

\begin{tabular}{lcc}
\hline & $\begin{array}{c}1991 \\
\text { participation } \\
\%\end{array}$ & $\begin{array}{c}\text { 1987-1991 } \\
\text { \%-points change }\end{array}$ \\
\hline & & \\
\hline Belgium & 2.4 & -0.4 \\
Federal Republic of Germany & 9.1 & -0.7 \\
Denmark & 25.1 & 0.7 \\
Greece & 2.8 & 0.1 \\
Spain & 6.9 & 0.2 \\
France & 4.3 & 0.5 \\
Ireland & 8.6 & 2.0 \\
Luxembourg & 5.7 & 1.3 \\
Netherlands & 25.5 & 1.7 \\
Portugal & 7.5 & 0.9 \\
United Kingdom & 17.2 & 3.6 \\
European Union & 10.5 & 0.8 \\
\hline
\end{tabular}

Source: EUROSTAT/ROA

Table 2.17. Participation in training by sales workers (4) in 1991 and \%-points change in the period 19871991

\begin{tabular}{lcc}
\hline & $\begin{array}{c}1991 \\
\text { participation } \\
\%\end{array}$ & $\begin{array}{c}\text { 1987-1991 } \\
\text { \%-points change }\end{array}$ \\
\hline Beuntry & & \\
\hline Fedgium & 2.4 & -0.4 \\
Denmark & 9.2 & -2.0 \\
Greece & 31.9 & 2.4 \\
Spain & 1.1 & -0.3 \\
France & 2.0 & 0.1 \\
Ireland & 2.8 & 0.1 \\
Luxembourg & 6.1 & -0.3 \\
Netherlands & 5.0 & 1.5 \\
Portugal & 24.0 & 5.2 \\
United Kingdom & 3.1 & 0.4 \\
European Union & 17.9 & 2.1 \\
& & 0.3 \\
\hline
\end{tabular}


$-33-$

Table 2.18. Participation in training by service workers (5) in 1991 and \%-points change in the period 1987-1991

\begin{tabular}{lcc}
\hline country & $\begin{array}{c}1991 \\
\text { participation } \\
\%\end{array}$ & $\begin{array}{c}1987-1991 \\
\% \text {-points change }\end{array}$ \\
& $\%$ & \\
\hline & & -0.5 \\
Belgium & 1.7 & -1.9 \\
Federal Republic of Germany & 9.2 & -0.1 \\
Denmark & 25.4 & -0.1 \\
Greece & 1.1 & 0.7 \\
Spain & 2.9 & 0.3 \\
France & 4.2 & 0.8 \\
Ireland & 7.8 & -0.3 \\
Luxembourg & 3.7 & 4.3 \\
Netherlands & 22.6 & 0.7 \\
Portugal & 3.1 & 3.5 \\
United Kingdom & 14.1 & 0.9 \\
European Union & & \\
\hline
\end{tabular}

Source: EUROSTAT/ROA

Table 2.19. Participation in training by agricultural, animal husbandry and forestry workers, fishermen and hunters (6) in 1991 and \%-points change in the period 1987-1991

\begin{tabular}{|c|c|c|}
\hline country & $\begin{array}{l}1991 \\
\text { participation } \\
\%\end{array}$ & $\begin{array}{l}1987-1991 \\
\% \text {-points change }\end{array}$ \\
\hline Belgium & 1.1 & 0.5 \\
\hline Federal Republic of Germany & 6.3 & -1.0 \\
\hline Denmark & 16.8 & 5.7 \\
\hline Greece & 0.1 & -0.2 \\
\hline Spain & 0.7 & 0.0 \\
\hline France & 1.3 & -0.5 \\
\hline Ireland & 2.1 & 0.2 \\
\hline Luxembourg & 4.5 & 2.7 \\
\hline Netherlands & 14.0 & 2.2 \\
\hline Portugal & 1.0 & 0.3 \\
\hline United Kingdom & 9.8 & 1.0 \\
\hline European Union & 3.3 & 0.0 \\
\hline
\end{tabular}

Source: EUROSTAT/ROA 
Table 2.20. Participation in training by production and related workers, transport equipment operators and labourers (7/8/9) in 1991 and \%-points change in the period 1987-1991

\begin{tabular}{lll}
\hline & $\begin{array}{l}1991 \\
\text { participation } \\
\%\end{array}$ & $\begin{array}{l}1987-1991 \\
\% \text {-points change }\end{array}$ \\
\hline country &
\end{tabular}

Belgium

$\begin{array}{rr}1.8 & -0.5 \\ 8.7 & -1.0 \\ 19.4 & -0.6 \\ 0.9 & -0.2 \\ 1.5 & 0.2 \\ 3.1 & -0.2 \\ 6.0 & 0.3 \\ 3.6 & 0.1 \\ 16.6 & 1.0 \\ 2.3 & 0.5 \\ 10.2 & 1.3 \\ 6.7 & \\ & -0.1\end{array}$

Denmark

Greece

Spain

France

Ireland

Luxembourg

Netherlands

Portugal

United Kingdom

$-0.1$

Source: EUROSTAT/ROA

\subsection{Some conclusions on upgrading and downgrading in the European Union}

In general we can conclude that there are strong indications of an upgrading of employment in the European Union. In section 2.2 we saw a shift in the employment share from lower skilled to intermediate skilled employment in the 'higher income' EU members and a shift from unskilled to lower skilled employment in the 'lower income' EU members. This has led to the situation in which the intermediate skilled workers have become the new 'average workers' in place of the lower skilled workers. The Federal Republic of Germany has had the greatest influence on this shift from lower skilled to intermediate skilled employment in the European Union. In this country the employment share of intermediate skilled workers rose by almost 16 percentage points. As just stated, the 'lower income' EU countries also show an upgrading of the skill level of their labour forces. Though these countries still employ large percentages of unskilled workers, the employment shares of unskilled workers are decreasing very rapidly. The situation in the United Kingdom is rather peculiar. Although this country has hardly any unskilled workers, more than $60 \%$ of the labour force falls in the lower skilled group. However, this special position of the United Kingdom can be explained by differences in assigning the 0 levels to the categories of skill levels. Whereas, in the OECD reports O-levels are assigned to the category of intermediate skilled workers, Eurostat assigns them to the lower skilled workers. In Section 2.3 we saw that, especially in Denmark, the Netherlands and the United Kingdom, participation in training is an important feature in the upgrading of the skill level of the workforce. For the United Kingdom this means that the upgrading of the labour force must have been established in particular by training policies. For Denmark both training and recruitment policies must have been responsible for the upgrading of the labour force. In the other EU countries upgrading of the labour force depended mainly on recruitment policies. 


\section{JOB-SEEKING AND THE STABILITY OF EMPLOYMENT RELATIONSHIPS}

\subsection{Introduction}

In this chapter some indicators of the level job-seeking activities and the stability of employment relationships will be described. These indicators are:

- the employment shares of workers with a temporary contract;

- the employment shares of workers who are looking for another job;

- the employment shares of workers working part-time.

The percentage of people looking for another job is a very straightforward indicator of the stability of employment relationships: the more workers looking for another job, the greater the instability of employment relationships in that occupational sector. The number of temporary contracts is also a quite direct indicator of the stability of employment relationships. However, from an employer's point of view it can also be seen as an indicator of employment flexibility. The percentage of people working part-time is more difficult to interpret. If people have a parttime job voluntarily it may increase job satisfaction and therefore increase stability in employment relationships. However, in the case of involuntary part-time work it probably diminishes job satisfaction and therefore decreases the stability in employment relationships. ${ }^{15}$ In section 3.2 we analyze the percentages of people looking for another job in the various Member States, differentiated by occupational sector. Moreover we describe the changes in jobseeking levels in the period 1987-1991. In section 3.3 the percentages of people working on a temporary contract, and changes in these levels, are analyzed for each of the Member States. Here we also differentiate occupational sectors. Section 3.4 analyses the percentages of parttime workers by occupational sector, and changes in these levels. In Section 3.5 we will make some concluding remarks.

\subsection{Job-seeking}

Table 3.1 shows the proportions of workers looking for another job. From the total working population in Europe $4.1 \%$ was looking for another job in 1991. Most striking in the table is the relatively high percentage, almost $10 \%$, of workers looking for another job in the Netherlands. Other countries with relatively high percentages are Denmark and the United Kingdom with $6.1 \%$ and $6.7 \%$ respectively. In France and Ireland the percentages are also above the EU average, while in the remaining Member States they are very low. In almost all countries the percentages of workers looking for another job have decreased quite markedly in the period 1987-1991. The average decrease was 0.9 percentage points. In general the countries with the smallest proportion of workers looking for another job show the smallest decrease in this proportion. However, in Spain, the percentage of people looking for another job has decreased the most. The total decrease in this country amounted 2.8 percentage points. Other countries with relatively high decreases in job-seeking activities are France, the Netherlands and Portugal.

15. Both groups are included in the population working part-time. 
One striking finding is the slight increase in job seekers which was recorded in the United Kingdom. This country shows to be the only EU Member State in which the proportion of workers looking for another job increased. In general the data presented seems to indicate that the proportion of workers looking for another job is cyclically sensitive. The better the state of the economy, the higher the proportion of people looking for another job.

Table 3.1. Percentage of total employment (total) looking for another job in 1991 and \%-points change in the period 1987-1991

\begin{tabular}{lcc}
\hline country & $\begin{array}{c}1991 \\
\text { looking } \\
\%\end{array}$ & $\begin{array}{c}1987-1991 \\
\% \text {-points change }\end{array}$ \\
\hline Belgium & 2.2 & -1.0 \\
Federal Republic of Germany & 2.0 & -0.3 \\
Denmark & 6.1 & -0.9 \\
Greece & 2.2 & -0.2 \\
Spain & 1.7 & -2.8 \\
France & 4.6 & -1.6 \\
Ireland & 4.7 & -1.0 \\
Luxembourg & 0.3 & 0.0 \\
Netherlands & 9.9 & -1.4 \\
Portugal & 2.6 & -1.3 \\
United Kingdom & 6.7 & 0.1 \\
European Union & & -0.9 \\
\hline
\end{tabular}

Source: EUROSTAT/ROA

Tables 3.2 to 3.8 show the employment shares of workers looking for another job, differentiated by occupational sector. The 'service workers' show the highest proportion of job seekers as can be seen in table 3.6. For all countries the proportions of 'service workers' looking for another job are higher than the average for all occupational sectors. However, this occupational sector also shows one of the largest decreases in the proportion of job seekers. The proportion of job seekers among 'service workers', across all the Member States, decreased by an average of 1.4 percentage points, and in Spain and France the proportions even decreased by 3.6 and 2.9 percentage points respectively. Another occupational sector with a relatively high percentage of job seekers is that of 'professional, technical and related workers' (table 3.2). Most remarkable in this table is the job-seeking activity of Dutch 'professional, technical and related workers', $13.5 \%$ of whom were looking for a new job (in 1991). The gap between the Netherlands and the other EU Member States is very large in this occupational sector. In chapter 2 we saw that 'professional, technical and related workers' showed the highest average skill level in the European Union. Moreover in this occupational category training investments are very high, as compared to other occupational groups (see table 2.15). However, the high potential mobility of these workers indicates that their human capital is to a great extent of a general character, which enables them to move to other firms. According to labour market segmentation theory this relatively high mobility is characteristic for 
'craft' or 'professional' labour market segments. (See Doeringer \& Piore, 1971). A remarkable fact, however, is the large decrease in the proportion of job seekers in Ireland in this occupational sector. Also remarkable is the relatively low proportion of 'administrative and managerial workers' looking for another job. On average $2.7 \%$ of all those employed in this occupational sector are looking for another job, as can be seen in table 3.3. In eight countries the proportion of job seekers in this occupational sector does not even reach the national threshold values. Keeping in mind that the skill level in this occupational sector was the second highest, this indicates that these workers are probably working on internal labour markets. This argument is supported by the observation that training activities in this occupational sector are very high (see table 2.15). The low proportion of 'agricultural, animal husbandry and forestry workers, fishermen and hunters' who are seeking a new job is in line with expectations. As many workers are independent farmers and family workers, job-seeking could be expected to be very low in this occupational sector. However, in Ireland the proportion of job seekers in this occupational sector reached $6 \%$, which is the highest proportion for any occupational sector in this country. The proportion of job seekers even showed a rise o 0.5 percentage points for Ireland, whereas on average the proportion of job seekers decreased by 1.4 percentage points in this occupational sector.

Table 3.2. Percentage of professional, technical and related workers (0/1) looking for another job in 1991 and \%-points change in the period 1987-1991

\begin{tabular}{lcc}
\hline country & $\begin{array}{c}1991 \\
\text { looking } \\
\%\end{array}$ & $\begin{array}{c}1987-1991 \\
\% \text {-points change }\end{array}$ \\
\hline Belgium & 2.7 & -0.6 \\
Federal Republic of Germany & 2.6 & -0.5 \\
Denmark & 6.7 & -1.3 \\
Greece & 1.8 & -0.5 \\
Spain & 1.5 & -2.9 \\
France & 3.7 & -2.2 \\
Ireland & 1.8 & -3.6 \\
Luxembourg & - & - \\
Netherlands & 13.5 & -0.5 \\
Portugal & 1.3 & -1.2 \\
United Kingdom & 6.7 & -0.7 \\
European Union & & -1.2 \\
\hline
\end{tabular}

Source: EUROSTAT/ROA

Probably the high mobility of these workers in Ireland indicates that in this country many workers are agricultural labourers with very unstable employment relationships. In this table the proportion of Dutch 'agricultural, animal husbandry and forestry workers, fishermen and hunters' looking for another job is very low. The levels of job-seeking activity of 'clerical and related workers' and 'sales workers' (see table 3.4 and 3.5 ) are quite similar to the average potential mobility figures. The proportions of workers looking for another job in both 
occupational sectors are relatively high in Denmark, the Netherlands and the United Kingdom. France and Ireland have values close to the European average. The other EU Member States have relatively low proportions of job seekers. For the 'clerical and related workers' the decrease in the proportion seeking new jobs is less than the average decrease.

Table 3.3. Percentage of administrative and managerial workers (2) looking for another job in 1991 and $\%$-points change in the period 1987-1991

\begin{tabular}{lcc}
\hline country & $\begin{array}{c}1991 \\
\text { looking } \\
\%\end{array}$ & $\begin{array}{c}\text { 1987-1991 } \\
\text { \%-points change }\end{array}$ \\
\hline Belgium & - & - \\
Federal Republic of Germany & 1.0 & -0.5 \\
Denmark & - & - \\
Greece & - & - \\
Spain & - & - \\
France & - & - \\
Ireland & - & -1.3 \\
Luxembourg & - & - \\
Netherlands & 5.1 & 0.8 \\
Portugal & - & -0.2 \\
United Kingdom & 5.1 & - \\
European Union & 2.7 & \\
\hline
\end{tabular}

Source: EUROSTAT/ROA

Table 3.4. Percentage of clerical and related workers (3) looking for another job in 1991 and \%-points change in the period 1987-1991

\begin{tabular}{lcc}
\hline country & $\begin{array}{c}1991 \\
\text { looking } \\
\%\end{array}$ & $\begin{array}{c}\text { 1987-1991 } \\
\text { \%-points change }\end{array}$ \\
\hline Belgium & 3.0 & -1.1 \\
Federal Republic of Germany & 2.0 & -0.2 \\
Denmark & 6.4 & -1.0 \\
Greece & 2.2 & 0.9 \\
Spain & 1.3 & -1.5 \\
France & 4.9 & -1.4 \\
Ireland & 5.3 & -0.4 \\
Luxembourg & - & - \\
Netherlands & 11.0 & -1.4 \\
Portugal & 2.7 & 0.4 \\
United Kingdom & 7.2 & 0.6 \\
European Union & 4.5 & -0.5 \\
\hline
\end{tabular}

Source: EUROSTAT/ROA 
$-39-$

Table 3.5. Percentage of sales workers (4) looking for another job in 1991 and \%-points change in the period 1987-1991

\begin{tabular}{lcc}
\hline country & $\begin{array}{c}1991 \\
\text { looking } \\
\%\end{array}$ & $\begin{array}{c}1987-1991 \\
\%-\text { points change }\end{array}$ \\
\hline Belgium & 2.1 & -1.4 \\
Federal Republic of Germany & 2.2 & -0.4 \\
Denmark & 8.5 & -1.6 \\
Greece & 2.3 & 0.3 \\
Spain & 1.6 & -2.8 \\
France & 4.8 & -1.2 \\
Ireland & 5.6 & -0.8 \\
Luxembourg & - & - \\
Netherlands & 8.3 & -2.2 \\
Portugal & 2.5 & -0.5 \\
United Kingdom & 7.0 & 0.2 \\
European Union & & -0.9 \\
\hline
\end{tabular}

Source: EUROSTAT/ROA

Table 3.6. Percentage of service workers (5) looking for another job in 1991 and \%-points change in the period 1987-1991

\begin{tabular}{lcc}
\hline country & $\begin{array}{c}1991 \\
\text { looking } \\
\%\end{array}$ & $\begin{array}{c}1987-1991 \\
\%-\text { points change }\end{array}$ \\
\hline Belgium & 3.9 & -1.2 \\
Federal Republic of Germany & 2.5 & -0.1 \\
Denmark & 8.5 & -0.6 \\
Greece & 3.0 & -0.2 \\
Spain & 3.5 & -3.6 \\
France & 6.9 & -2.9 \\
Ireland & 7.1 & -0.8 \\
Luxembourg & - & - \\
Netherlands & 11.4 & -1.4 \\
Portugal & 4.4 & -1.6 \\
United Kingdom & 7.5 & 0.0 \\
European Union & 5.7 & -1.4 \\
\hline
\end{tabular}

Source: EUROSTAT/ROA 
Table 3.7. Percentage of agricultural, animal husbandry and forestry workers, fishermen and hunters (6) looking for another job in 1991 and \%-points change in the period 1987-1991

\begin{tabular}{lcc}
\hline country & $\begin{array}{c}1991 \\
\text { looking } \\
\%\end{array}$ & $\begin{array}{c}1987-1991 \\
\%-\text { points change }\end{array}$ \\
\hline Belgium & - & - \\
Federal Republic of Germany & 1.5 & -1.2 \\
Denmark & 3.1 & -0.8 \\
Greece & 2.1 & -0.6 \\
Spain & 3.5 & -3.3 \\
France & 2.5 & -0.3 \\
Ireland & 6.0 & 0.5 \\
Luxembourg & - & - \\
Netherlands & 4.1 & -0.4 \\
Portugal & 3.6 & -2.1 \\
United Kingdom & 5.3 & -1.1 \\
European Union & 3.0 & -1.4 \\
\hline
\end{tabular}

Source: EUROSTAT/ROA

Table 3.8. Percentage of production and related workers, transport equipment operators and labourers $(7 / 8 / 9)$ looking for another job in 1991 and \%-points change in the period 1987-1991

\begin{tabular}{lcc}
\hline country & $\begin{array}{c}1991 \\
\text { looking } \\
\%\end{array}$ & $\begin{array}{c}1987-1991 \\
\%-\text { points change }\end{array}$ \\
\hline Belgium & 1.1 & -1.2 \\
Federal Republic of Germany & 1.7 & -0.2 \\
Denmark & 5.5 & -0.2 \\
Greece & 2.3 & -0.5 \\
Spain & 1.0 & -2.6 \\
France & 4.4 & -1.4 \\
Ireland & 4.5 & -0.7 \\
Luxembourg & 0.9 & 0.9 \\
Netherlands & 7.5 & -2.5 \\
Portugal & 1.9 & -1.5 \\
United Kingdom & 6.1 & 0.0 \\
European Union & 3.4 & -1.0 \\
\hline
\end{tabular}

Source: EUROSTAT/ROA

\subsection{Temporary contracts}

Temporary contracts increase employment flexibility for employers. If a firm's economic situation is good it is easy to increase the workforce, whereas in economic downturns it is rather easy to discharge these workers. However, people working on a temporary contract tend 
to quit more easily if they find another employer offering a permanent contract. This may also decrease the stability of employment relations. In the European Union $9.3 \%$ of the total workforce are employed under temporary contracts. Table 3.9 shows that in general the differences between the various Member States are not extremely large. Belgium shows the smallest proportion of workers on a temporary contract and Spain the largest proportion, with $4 \%$ and $24.1 \%$ respectively. The proportion of workers on a temporary contract in Spain is $12 \%$ higher than in Portugal which has the second highest proportion. ${ }^{16}$ The table shows relatively low proportions of workers on a temporary contract for Ireland, the Netherlands and the United Kingdom. It also shows that on average the proportion of workers on a temporary contract has increased by 1.4 percentage points in the period 1987-1991. Remarkably in Spain the proportion employed on a temporary contract increased by 13.2 percentage points. This gets even more peculiar when we see that France has the second biggest increase, but with only 2.7 percentage points, whereas in five other countries the proportions decreased. Obviously a shift in employment policies must have occurred in Spain.

Table 3.9. Percentage of total employment (total) with a temporary contract in 1991 and \%-points change in the period 1987-1991

\begin{tabular}{lcc}
\hline country & $\begin{array}{c}1991 \\
\text { temporary } \\
\%\end{array}$ & $\begin{array}{c}1987-1991 \\
\% \text {-points change }\end{array}$ \\
\hline Belgium & & \\
Federal Republic of Germany & 4.0 & -0.4 \\
Denmark & 8.1 & -1.9 \\
Greece & 10.5 & 0.3 \\
Spain & 7.9 & -0.6 \\
France & 24.1 & 13.2 \\
Ireland & 8.7 & 2.7 \\
Luxembourg & 5.3 & 0.2 \\
Netherlands & 2.0 & -0.2 \\
Portugal & 6.7 & -1.3 \\
United Kingdom & 11.9 & 0.0 \\
& 4.8 & -0.7 \\
European Union & & 1.4 \\
\hline
\end{tabular}

Source: EUROSTAT/ROA

Tables 3.10 to 3.16 show the proportions of workers with temporary contracts, differentiated by occupational sectors. The occupational sector with the largest proportion of workers with a temporary contract is that of 'service workers', as can be seen in table 3.14. The profile of the proportions across the various Member States in this occupational sector is broadly the same as is seen for all occupational sectors in table 3.9, above, but the growth for 'service workers' has

16. This high proportion for Spain can not be declared by statistical measurement, because since 1987 the proportion of workers with temporary contracts in Spain shows an stable, annual strong increasing, trend. 
been higher across the board. Table 3.16 shows that another occupational sector with a relatively large proportion of workers with a temporary contract is that of 'production and related workers, transport equipment operators and labourers'. In this occupational sector the relatively low proportions of people working on a temporary contract in Portugal and Ireland and the relatively high proportion in Greece are striking. It is also very remarkable that although only Spain and France show increasing proportions of workers with a temporary contract in the period 1987-1991, the European average for this occupational sector increased by 1.6 percentage points. Table 3.11 differs most from the general picture sketched in table 3.9. In the occupational sector of 'administrative and managerial workers' only $1.7 \%$ of the workers in the European Union have a temporary contract. In most countries the proportions of workers with a temporary contract in this occupational sector do not even reach their respective threshold values. It is also the only occupational sector in which the proportion of workers with a temporary contract slightly decreased. Another occupational sector with a relatively low proportion of workers with a temporary contract is that of 'sales workers', which is presented in table 3.13. On average $7.1 \%$ of all workers in this occupational sector have temporary contracts. Most remarkable in this table is the relatively high proportion of workers with a temporary contract in Denmark. This is the only country having a proportion of workers in this occupational sector with a temporary contract which is higher than its average proportion for all occupational sectors. Another remarkable feature in this table is the decrease in the proportion of workers with a temporary contract in the Netherlands, by 3.3 percentage points. For the occupational sector of 'agricultural, animal husbandry and forestry workers, fishermen and hunters' one would expect a low proportion of workers with a temporary contract. Table 3.15 shows that on average $7.2 \%$ of all workers employed in this sector have a temporary contract. However, it is very remarkable that 1 out of 5 workers employed in this occupational sector in Spain has a temporary contract. In this country the increase in the proportion of workers with a temporary contract has been relatively small in this occupational sector. Tables 3.11 and 3.12 show the same general picture as was seen in table 3.9. Belgium has the lowest proportions of workers with a temporary contract, while Spain has proportions much higher than in the other Member States. 
$-43-$

Table 3.10. Percentage of professional, technical and related workers $(0 / 1)$ with a temporary contract in 1991 and \%-points change in the period 1987-1991

\begin{tabular}{lcc}
\hline & $\begin{array}{c}1991 \\
\text { temporary } \\
\%\end{array}$ & $\begin{array}{c}1987-1991 \\
\text { \%-points change }\end{array}$ \\
\hline Belgium & 5.8 & \\
Federal Republic of Germany & 9.1 & -0.3 \\
Denmark & 11.6 & -1.1 \\
Greece & 7.4 & 2.3 \\
Spain & 18.7 & -0.6 \\
France & 9.3 & 10.0 \\
Ireland & 6.7 & 4.1 \\
Luxembourg & - & -0.7 \\
Netherlands & 8.8 & - \\
Portugal & 10.4 & -1.6 \\
United Kingdom & 6.2 & 2.4 \\
European Union & 9.1 & -0.9 \\
& & 1.2 \\
\hline
\end{tabular}

Source: EUROSTAT/ROA

Table 3.11. Percentage of administrative and managerial workers (2) with a temporary contract in 1991 and \%-points change in the period 1987-1991

\begin{tabular}{lcc}
\hline country & $\begin{array}{c}1991 \\
\text { temporary } \\
\%\end{array}$ & $\begin{array}{c}\text { 1987-1991 } \\
\% \text {-points change }\end{array}$ \\
\hline Belgium & - & - \\
Federal Republic of Germany & 3.8 & -0.5 \\
Denmark & - & - \\
Greece & - & - \\
Spain & 2.2 & - \\
France & - & - \\
Ireland & - & - \\
Luxembourg & - & - \\
Netherlands & - & -0.2 \\
Portugal & 1.1 & -0.1 \\
United Kingdom & 1.7 & - \\
European Union & & \\
\hline
\end{tabular}

Source: EUROSTAT/ROA 
$-44-$

Table 3.12. Percentage of clerical and related workers (3) with a temporary contract in 1991 and \%points change in the period 1987-1991

\begin{tabular}{lcc}
\hline country & $\begin{array}{c}1991 \\
\text { temporary } \\
\%\end{array}$ & $\begin{array}{c}1987-1991 \\
\% \text {-points change }\end{array}$ \\
& & \\
\hline & & \\
Belgium & 5.1 & -0.5 \\
Federal Republic of Germany & 7.0 & -1.9 \\
Denmark & 9.6 & -0.9 \\
Greece & 6.2 & 0.9 \\
Spain & 22.6 & 13.8 \\
France & 8.4 & 2.6 \\
Ireland & 7.3 & 1.8 \\
Luxembourg & 1.7 & 0.3 \\
Netherlands & 7.4 & -0.5 \\
Portugal & 11.8 & 3.3 \\
United Kingdom & 5.5 & 0.4 \\
European Union & 8.4 & 1.4 \\
\end{tabular}

Source: EUROSTAT/ROA

Table 3.13. Percentage of sales workers (4) with a temporary contract in 1991 and \%-points change in the period 1987-1991

\begin{tabular}{lcc}
\hline country & $\begin{array}{c}1991 \\
\text { temporary } \\
\%\end{array}$ & $\begin{array}{c}\text { 1987-1991 } \\
\% \text {-points change }\end{array}$ \\
\hline Belgium & 2.2 & 0.4 \\
Federal Republic of Germany & 7.2 & -2.6 \\
Denmark & 10.7 & -0.1 \\
Greece & 4.3 & 0.9 \\
Spain & 16.4 & 10.8 \\
France & 5.0 & 1.4 \\
Ireland & 3.9 & 0.7 \\
Luxembourg & 2.2 & -2.3 \\
Netherlands & 4.7 & -3.3 \\
Portugal & 8.5 & 0.9 \\
United Kingdom & 5.0 & 0.1 \\
European Union & 7.1 & 1.0 \\
\hline
\end{tabular}

Source: EUROSTAT/ROA 
$-45-$

Table 3.14. Percentage of service workers (5) with a temporary contract in 1991 and \%-points change in the period 1987-1991

\begin{tabular}{lcc}
\hline country & $\begin{array}{c}1991 \\
\text { temporary } \\
\%\end{array}$ & $\begin{array}{c}1987-1991 \\
\% \text {-points change }\end{array}$ \\
\hline Belgium & 6.8 & -0.4 \\
Federal Republic of Germany & 9.0 & -2.4 \\
Denmark & 12.5 & 3.2 \\
Greece & 11.4 & -2.1 \\
Spain & 28.1 & 14.9 \\
France & 12.7 & 4.8 \\
Ireland & 10.2 & -0.3 \\
Luxembourg & 4.1 & -0.8 \\
Netherlands & 8.5 & -0.6 \\
Portugal & 15.9 & -0.3 \\
United Kingdom & 7.5 & -0.5 \\
European Union & 12.3 & 2.5 \\
\hline
\end{tabular}

Source: EUROSTAT/ROA

Table 3.15. Percentage of agricultural, animal husbandry and forestry workers, fishermen and hunters (6) with a temporary contract in 1991 and \%-points change in the period 1987-1991

\begin{tabular}{lcc}
\hline country & $\begin{array}{c}1991 \\
\text { temporary } \\
\%\end{array}$ & $\begin{array}{c}\text { 1987-1991 } \\
\% \text {-points change }\end{array}$ \\
\hline Belgium & - & - \\
Federal Republic of Germany & 5.4 & -0.8 \\
Denmark & 5.2 & 0.2 \\
Greece & 1.7 & -0.9 \\
Spain & 20.0 & 7.5 \\
France & 3.4 & 0.9 \\
Ireland & - & - \\
Luxembourg & - & -4.0 \\
Netherlands & 4.1 & -1.6 \\
Portugal & 5.1 & -4.7 \\
United Kingdom & 4.6 & 0.7 \\
European Union & 7.2 & \\
\hline
\end{tabular}

Source: EUROSTAT/ROA 
Table 3.16. Percentage of production and related workers, transport equipment operators and labourers $(7 / 8 / 9)$ with a temporary contract in 1991 and \%-points change in the period 1987-1991

\begin{tabular}{lcc}
\hline country & $\begin{array}{c}1991 \\
\text { temporary } \\
\%\end{array}$ & $\begin{array}{c}1987-1991 \\
\% \text {-points change }\end{array}$ \\
\hline & & \\
Belgium & 2.4 & -1.0 \\
Federal Republic of Germany & 8.9 & -2.4 \\
Denmark & 11.6 & -0.7 \\
Greece & 13.8 & -1.4 \\
Spain & 29.4 & 16.6 \\
France & 8.9 & 1.7 \\
Ireland & 4.9 & -0.4 \\
Luxembourg & 2.5 & 0.3 \\
Netherlands & 5.9 & -1.1 \\
Portugal & 15.5 & -1.3 \\
United Kingdom & 2.6 & -1.8 \\
European Union & 10.6 & 1.6 \\
\hline
\end{tabular}

Source: EUROSTAT/ROA

\subsection{Part-time work}

As noted in the introduction to this chapter, part-time work may increase or decrease job satisfaction. This strongly depends on the reason for working part-time. If part-time work is voluntarily, it probably increases job satisfaction, whereas involuntary part-time work decreases job satisfaction. Traditionally it has been especially women who have worked part-time, and this part-time work has mainly been in the occupational sectors of 'service workers' and 'sales workers' (see chapter 4). From table 3.17 we can see that on average $15 \%$ of the total working population in the various Member States works part-time. The differences between the various Member States are however very large. The Netherlands shows by far the largest proportion in part-time employment $(32.4 \%)$. Remarkably, the countries with the highest proportions of workers looking for another job also have the largest proportion of part-time workers. Greece, Spain and Portugal show relatively small proportions of part-time workers. This might indicate that part-time work correlates positively with skill level, as the same ranking could be observed in chapter 2, and therefore also with the stability of employment relationships. On average the employment share of part-time workers increased by 1 percentage point. However, the various EU countries show opposing trends. The proportion of part-time workers decreased by 1.5 percentage points in Denmark and Greece and by 1 percentage point in Spain in the period 1987-1991, whereas in the other EU Member States the proportion of part-time workers increased. The Netherlands, the Federal Republic of Germany and Belgium show the greatest increases in the proportion of part-time working, with $3.1,2.8$ and 2 percentage points respectively. 
Table 3.17. Percentage of total employment working part-time in 1991 and \%-points change in the period 1987-1991

\begin{tabular}{lcc}
\hline country & $\begin{array}{c}1991 \\
\text { part-time } \\
\%\end{array}$ & $\begin{array}{c}\text { 1987-1991 } \\
\text { \%-points change }\end{array}$ \\
\hline & 11.7 & \\
Belgium & 15.1 & 2.0 \\
Federal Republic of Germany & 22.6 & 2.8 \\
Denmark & 3.4 & -1.5 \\
Greece & 4.5 & -1.5 \\
Spain & 11.9 & -1.0 \\
France & 8.3 & 0.4 \\
Ireland & 7.5 & 1.3 \\
Luxembourg & 32.4 & 1.0 \\
Netherlands & 5.8 & 3.1 \\
Portugal & 22.3 & 0.3 \\
United Kingdom & 15.0 & 1.1 \\
European Union & & 1.0 \\
\hline
\end{tabular}

Source: EUROSTAT/ROA

Tables 3.18 to 3.24 show that the differences between occupational sectors are very large. Of all 'service workers', $33.8 \%$ have part-time jobs (table 3.22 ), whereas only $4.6 \%$ of all 'production and related workers, transport equipment operators and labourers' work part-time (3.24). In the Netherlands and the United Kingdom more than half of the 'service workers' have part-time jobs. It is also remarkable that the proportion of persons working part-time in the Federal Republic of Germany increased by 6.1 percentage points. This is the highest increase in the proportion of part-time working workers realized in any occupational sector in this country. 'Sales workers' also show a relatively high proportion of part-time workers, as table 3.21 shows. On average 1 out of 5 people employed in this occupational sector has a part-time job. Not surprisingly the Netherlands and the United Kingdom again show the largest proportions of part-time workers and Greece, Spain and Portugal again show the smallest proportions of parttime workers. Most striking in this table is the decrease in part-time work by 'sales workers' by 7.7 percentage points in Denmark. Also remarkable is the increase in part-time workers in this occupational sector in the Federal Republic of Germany. In this country the employment share of part-time workers increased by 4.3 percentage points. Another occupational sector that is characterized by a high proportion of part-time workers is that of 'clerical and related workers'. The proportions of 'clerical and related workers' working part-time are given in table 3.20. On average $19.3 \%$ of the labour force employed in this occupational sector works part-time. The table shows the widest gap between Greece, Spain and Portugal and the other EU Member States. This employment sector also shows the largest Europe-wide increase in part-time workers, by 1.6 percentage points in the period 1987-1991. The highest increases in part-time workers in this occupational sector took place in the Netherlands and the Federal Republic of Germany, with 4.6 and 3 percentage points respectively. Table 3.18 shows the percentages of part-time employment for 'professional, technical and related workers'. This is the only table 
that is rather similar to the average picture given in table 3.17. Denmark, the Netherlands and the United Kingdom have the highest proportions of part-time workers again, whereas Greece, Spain and Portugal have the smallest proportions of people working part-time. In Denmark, Greece and Spain the proportions of part-time work in this occupational sector also decreased. The employment share of 'production and related workers, transport equipment operators and labourers' working part-time is the smallest in the European Union, as is shown in table 3.24. On average only $4.6 \%$ of those employed in this occupational sector work part-time, and the rate even decreased by 0.1 percentage points in the period 1987-1991. From table 3.19 we can see that the occupational sector of 'administrative and managerial workers' also has a low proportion of part-time workers. Only $5.6 \%$ of the workforce in this occupational sector have part-time jobs. However this occupational sector has the second largest increase in the proportion of part-time workers, with an increase of 1.5 percentage points. In Denmark the proportion of part-time workers increased by 3.1 percentage points. Moreover in this occupational sector the proportions of part-time workers in France and the Netherlands decreased by 2.5 and 0.3 percentage points respectively. It is also striking that the proportion of people working part-time again decreased very markedly in Denmark, Greece and Spain. With regard to 'agricultural, animal husbandry and forestry workers, fishermen and hunters' the very small proportion of people working part-time in the United Kingdom and the very large decrease in the proportion of part-time working workers is most striking (see table 3.23).

Table 3.18. Percentage of professional, technical and related workers (0/1) working part-time in 1991 and $\%$-points change in the period 1987-1991

\begin{tabular}{lcc}
\hline & $\begin{array}{c}1991 \\
\text { part-time } \\
\%\end{array}$ & $\begin{array}{c}1987-1991 \\
\text { \%-points change }\end{array}$ \\
\hline & & \\
\hline Belgium & 14.9 & 2.3 \\
Federal Republic of Germany & 16.0 & 3.4 \\
Denmark & 26.9 & -0.1 \\
Greece & 3.9 & -1.6 \\
Spain & 5.7 & -1.0 \\
France & 10.5 & 0.2 \\
Ireland & 8.2 & 1.6 \\
Luxembourg & 6.6 & 1.9 \\
Netherlands & 36.5 & 2.0 \\
Portugal & 4.3 & 1.0 \\
United Kingdom & 18.8 & 1.1 \\
European Union & 16.0 & 1.4 \\
\hline
\end{tabular}

Source: EUROSTAT/ROA 
Table 3.19. Percentage of part-time working administrative and managerial workers (2) working part-time in 1991 and \%-points change in the period 1987-1991

\begin{tabular}{lcc}
\hline country & $\begin{array}{c}1991 \\
\text { part-time } \\
\%\end{array}$ & $\begin{array}{c}\text { 1987-1991 } \\
\text { \%-points change }\end{array}$ \\
\hline Belgium & 4.0 & 2.1 \\
Federal Republic of Germany & 4.4 & 1.4 \\
Denmark & 4.8 & 3.1 \\
Greece & 0.7 & -0.2 \\
Spain & 0.8 & 0.0 \\
France & 1.3 & -2.5 \\
Ireland & - & - \\
Luxembourg & - & -0.3 \\
Netherlands & 11.9 & 0.4 \\
Portugal & 1.1 & 2.7 \\
United Kingdom & 7.2 & 1.5 \\
European Union & 5.6 & \\
\hline
\end{tabular}

Source: EUROSTAT/ROA

Table 3.20. Percentage of clerical and related workers (3) working part-time in 1991 and \%-points change in the period 1987-1991

\begin{tabular}{lcc}
\hline & $\begin{array}{c}1991 \\
\text { part-time } \\
\%\end{array}$ & $\begin{array}{c}\text { 1987-1991 } \\
\text { \%-points change }\end{array}$ \\
\hline Beuntry & 13.7 & \\
Federal Republic of Germany & 22.1 & 1.7 \\
Denmark & 24.6 & 3.0 \\
Greece & 2.6 & -2.6 \\
Spain & 2.7 & -2.6 \\
France & 15.1 & -0.8 \\
Ireland & 8.6 & 1.7 \\
Luxembourg & 7.0 & 2.0 \\
Netherlands & 33.0 & 3.0 \\
Portugal & 1.7 & 4.6 \\
United Kingdom & 27.3 & 0.4 \\
European Union & 19.3 & 2.0 \\
\hline
\end{tabular}

Source: EUROSTAT/ROA 
$-50-$

Table 3.21. Percentage of sales workers (4) working part-time in 1991 and \%-points change in the period 1987-1991

\begin{tabular}{lcc}
\hline & $\begin{array}{c}1991 \\
\text { part-time } \\
\%\end{array}$ & $\begin{array}{c}1987-1991 \\
\text { \%-points change }\end{array}$ \\
\hline Belgium & 13.1 & \\
Federal Republic of Germany & 23.7 & 1.2 \\
Denmark & 26.7 & 4.3 \\
Greece & 3.1 & -7.7 \\
Spain & 4.3 & -1.0 \\
France & 12.7 & -1.6 \\
Ireland & 11.7 & 0.3 \\
Luxembourg & 5.9 & 2.5 \\
Netherlands & 41.6 & -1.3 \\
Portugal & 4.6 & 3.2 \\
United Kingdom & 34.2 & -1.1 \\
European Union & 20.9 & 1.7 \\
& & 1.0 \\
\hline
\end{tabular}

Source: EUROSTAT/ROA

Table 3.22. Percentage of working service workers (5) working part-time in 1991 and \%-points change in the period 1987-1991

\begin{tabular}{lcc}
\hline & $\begin{array}{c}1991 \\
\text { part-time } \\
\%\end{array}$ & $\begin{array}{c}\text { 1987-1991 } \\
\% \text {-points change }\end{array}$ \\
\hline country & & \\
\hline Belgium & 30.4 & 4.4 \\
Dederal Republic of Germany & 32.5 & 6.1 \\
Denmark & 47.2 & -2.8 \\
Greece & 5.1 & -0.8 \\
Spain & 14.8 & -0.8 \\
France & 27.4 & 0.3 \\
Ireland & 20.6 & 2.5 \\
Luxembourg & 22.0 & -1.7 \\
Netherlands & 63.0 & 3.3 \\
Portugal & 13.5 & -1.7 \\
United Kingdom & 50.4 & -2.4 \\
European Union & 33.8 & 0.4 \\
\hline
\end{tabular}

Source: EUROSTAT/ROA 
Table 3.23. Percentage of agricultural, animal husbandry and forestry workers, fishermen and hunters (6) in 1991 and \%-points change in the period 1987-1991

\begin{tabular}{lcc}
\hline country & $\begin{array}{c}1991 \\
\text { part-time } \\
\%\end{array}$ & $\begin{array}{c}\text { 1987-1991 } \\
\text { \%-points change }\end{array}$ \\
\hline & 6.4 & \\
Belgium & 16.5 & 0.2 \\
Federal Republic of Germany & 11.0 & 0.0 \\
Denmark & 5.0 & 3.2 \\
Greece & 4.6 & -2.6 \\
Spain & 13.1 & -1.2 \\
France & 5.9 & -0.7 \\
Ireland & 7.6 & -0.3 \\
Luxembourg & 29.0 & 2.1 \\
Netherlands & 13.1 & 6.1 \\
Portugal & 9.8 & 4.0 \\
United Kingdom & 11.0 & -5.6 \\
European Union & & -0.3 \\
\hline
\end{tabular}

Source: EUROSTAT/ROA

Table 3.24. Percentage of production and related workers, transport equipment operators and labourers (7/8/9) working part-time in 1991 and \%-points change in the period 1987-1991

\begin{tabular}{lcc}
\hline & $\begin{array}{c}1991 \\
\text { part-time } \\
\%\end{array}$ & $\begin{array}{l}\text { 1987-1991 } \\
\text { \%-points change }\end{array}$ \\
\hline & & \\
Belgium & 3.1 & 0.4 \\
Federal Republic of Germany & 4.3 & 0.8 \\
Denmark & 13.9 & 0.5 \\
Greece & 2.2 & -0.5 \\
Spain & 1.3 & -0.9 \\
France & 3.3 & -0.3 \\
Ireland & 3.9 & 0.6 \\
Luxembourg & 3.0 & 1.0 \\
Netherlands & 12.5 & 0.5 \\
Portugal & 2.7 & 0.0 \\
United Kingdom & 6.9 & -0.4 \\
European Union & & -0.1 \\
\hline
\end{tabular}

Source: EUROSTAT/ROA

\subsection{Some concluding remarks}

Table 3.25 summarises the percentages of the national workforces looking for another job, working with a temporary contract and working part-time, respectively. At first sight Denmark seems to have the least stable employment relationships, as all three indicators lie above the 
European average. Another country with employment relationships that seem rather unstable is the Netherlands. This country has both the highest percentages of workers looking for another job and of part-time workers. It is remarkable that the countries which have the highest percentages of workers looking for another job also have the highest percentages working parttime.

The employment structure seems to be most stable in Belgium, the Federal Republic of Germany and Greece, as all three countries have percentages on the three indicators of the stability of employment relationships which lie below the European averages. The table also shows the extraordinary position of Spain and Portugal, as these country are among the countries with the lowest percentages of workers looking for another job and working part-time, but the highest percentages for workers with a temporary contract.

Table 3.25. Job-seeking and employment relationship stability in the European Union in 1991

\begin{tabular}{lccc}
\hline & $\begin{array}{c}1991 \\
\text { job-seeking } \\
\%\end{array}$ & $\begin{array}{c}1991 \\
\text { temporary } \\
\%\end{array}$ & $\begin{array}{c}1991 \\
\text { part-time work } \\
\%\end{array}$ \\
\hline Belgium & 2.2 & 4.0 & 11.7 \\
Federal Republic of Germany & 2.0 & 8.1 & 15.1 \\
Denmark & 6.1 & 10.5 & 22.6 \\
Greece & 2.2 & 7.9 & 3.4 \\
Spain & 1.7 & 24.1 & 4.5 \\
France & 4.6 & 8.7 & 11.9 \\
Ireland & 4.7 & 5.3 & 8.3 \\
Luxembourg & 0.3 & 2.0 & 7.5 \\
Netherlands & 9.9 & 6.7 & 32.4 \\
Portugal & 2.6 & 11.9 & 5.8 \\
United Kingdom & 6.7 & 4.8 & 22.3 \\
European Union & 4.1 & 9.3 & 15.0 \\
\hline
\end{tabular}

Source: EUROSTAT/ROA

Table 3.26 shows that there are great differences in the stability of employment relationships in the various occupational sectors. The table shows that 'administrative and managerial workers' have the most stable employment relationships. Only $2.7 \%$ of all 'administrative and managerial workers' are looking for another job. This low rate of job-seeking activities may be influenced by the low proportions of workers with a temporary or part-time contract. Another occupational sector characterized by rather stable employment relationships is that of 'agricultural, animal husbandry, and forestry workers, fishermen and hunters'. In this occupational sector $3 \%$ of the working population are looking for another job, while $7.2 \%$ have a temporary contract and $11 \%$ are working part-time. Although the percentages for this occupational sector are much higher than for the 'administrative and managerial workers', they still lie well below the average level. Although the occupational sector of 'production and related workers, transport equipment operators and labourers' has a relatively high percentage of workers with a temporary contract, 
job satisfaction seem to be rather high as the percentage of workers looking for another job is only $3.4 \%$. By far the most unstable occupational sector is that of 'service workers'. This is the occupational sector with the highest percentage of job-seeking activity, and thus probably the lowest job satisfaction. This occupational sector also shows the highest percentages of parttime and temporary workers. According to the labour market segmentation theory most 'service workers' work in the 'secondary' segment of the labour market, in which the skills required are relatively unspecific, so that they are more easily replaceable. 'Clerical and related workers' and 'sales workers' also show signs of relatively unstable employment relationships. Although the percentage of workers with a temporary contract is below the European average, the percentages looking for another job or working part-time lie well above the European average in these two occupational sectors. In general the table seems to indicate that the occupational sectors with the highest proportions of job-seekers also have the highest percentages of parttime workers. Finally, we can conclude that the occupational sector with the highest percentage of job seekers also shows the highest percentage of workers with a temporary contract, whereas the occupational sector with the lowest percentage of job seekers has the lowest percentage of workers with a temporary contract.

Table 3.26. Job-seeking and employment relationship stability by occupational sector in the European Union in 1991

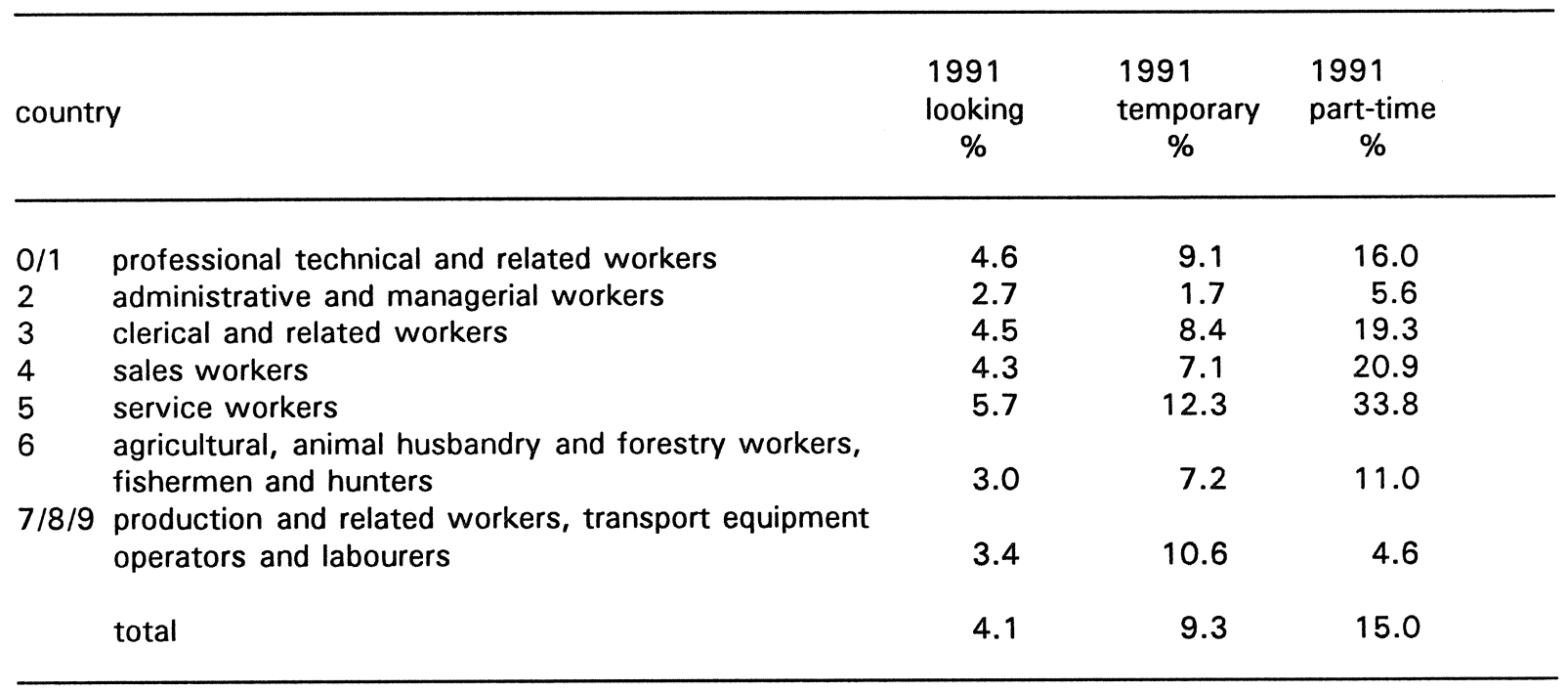




\section{THE POSITION OF WOMEN ON THE LABOUR MARKET}

\subsection{Introduction}

Women make up $41 \%$ of total employment in the European Union. Traditionally female employment is associated with care-giving and administrative occupations. In this chapter we describe the relative position of women on the labour market in order to see if this traditional picture of working women is still true and whether the gap between men and women has narrowed. Various aspects of female employment will be examined in this chapter. Section 4.2 concerns women's share in total employment in the various Member States, differentiated by occupational sectors. Rather than looking at the proportion of employment in each sector which is given to women, to see whether women's participation rates are equalling those of men, we will look at the spread of women's employment across the occupational sectors, to build up a profile of 'woman's work' in each country, and then compare this profile with the profile for all employment in the country. The objective is to see to what extent women tend to be employed in different occupational sectors than men, and whether the trend is to divergence or convergence in the structure of employment. In section 4.3 we will describe a related issue, which concerns the skill level of female workers and their participation in training. These are two important factors that depend largely on the occupational sectors in which women work and thereby also determine to what extent the gap between man and women can be overcome. In section 4.4 we will describe some indicators of the stability of employment relationships for women. One of the questions here is the proportion of women seeking other jobs. This is a straightforward indicator on how satisfied women are with the job they have. A second question concerns the relative importance for women of part-time work. A last question deals with the proportion of women in temporary as opposed to permanent employment. Together, the three indicators discussed in this sector provide evidence of the quality of the jobs occupied by women as expressed by the conditions attached to them.

\subsection{The occupational structure of female employment}

Figure 4.1 describes the employment shares of women as a percentage of total employment. As noted above, about $41 \%$ of total employment in the European Union is undertaken by women. In Spain about $32 \%$ of all jobs are occupied by women, whereas in Denmark approximately $46 \%$ of the workforce is female. This difference is rather small if we take into account that the Northern European countries have a much longer tradition of female labour participation. Surprisingly, Portugal shows a relatively high female employment share. Where one would expect an employment share similar to that in Greece or Spain, Portugal's actual figures are the third highest.

Figure 4.2 shows that women have a European average of $45.8 \%$ of the employment in the occupational sector of 'professional technical and related workers'. In Denmark and Portugal more than half of the total employment in this occupational sector is held by women. In Germany relatively few women work in this occupational sector. 
Approximately 1 out of 4 'administrative and managerial workers' is female in the European Union, as can be seen in figure 4.3. However, the differences between the various Member States are relatively great in this occupational sector. The female employment share in this occupational sector ranges from $9.1 \%$ in Spain to $35.7 \%$ in the United Kingdom.

Figure 4.4 also shows a very diverse picture. On average $64.1 \%$ of all 'clerical and related workers' are female. The figure indicates that in half of the Member States this occupational sector can be described as a typical feminine occupational field. ${ }^{17}$ In Spain, Portugal and Greece women have relatively small employment shares in this occupational sector, whereas Denmark and the United Kingdom show a relatively high female employment share.

Some $49.3 \%$ of all 'sales workers' are female. Table 4.5 shows that, remarkably, the employment shares of women in Greece, Ireland and the Netherlands are relatively small in this occupational sector, and the share in the Federal Republic of Germany is relatively high.

Figure 4.6 shows the employment share of female 'service workers' in the various EU countries. In most Member States this occupational sector can be defined as typical feminine occupational field. Only in Greece, Spain and Ireland do women show employment shares of less than $60 \%$ in this occupational sector. In the Netherlands women have an employment share in this sector of over $70 \%$.

Figure 4.7 shows that it is in Portugal that women have the highest employment share in the occupational sector of 'agricultural, animal husbandry and forestry workers, fishermen and hunters'. This figure also shows the largest difference between the highest and lowest female employment shares, with Portugal at $53.4 \%$ and Ireland at $8.6 \%$. Other countries with relatively low employment shares for women in this occupational sector are Denmark and the United Kingdom, two countries in which the employment share of women is in general the highest of the European Union, as was shown in figure 4.1.

Finally, figure 4.8 shows the employment shares of female 'production and related workers, transport equipment operators and labourers' in the various Member States. The figure shows that women have by far their smallest employment share in this occupational sector. Portugal shows the highest employment share in this occupational sector with $26.1 \%$, whereas the Netherlands shows the smallest female employment share with $9.1 \%$.

17. Siegers (1979) defines a typical feminine sector as an occupational sector in which more than $60 \%$ of all jobs are occupied by women. 
$-56-$

Figure 4.1. Employment share of females (all sectors) as a proportion of total national employment in 1991

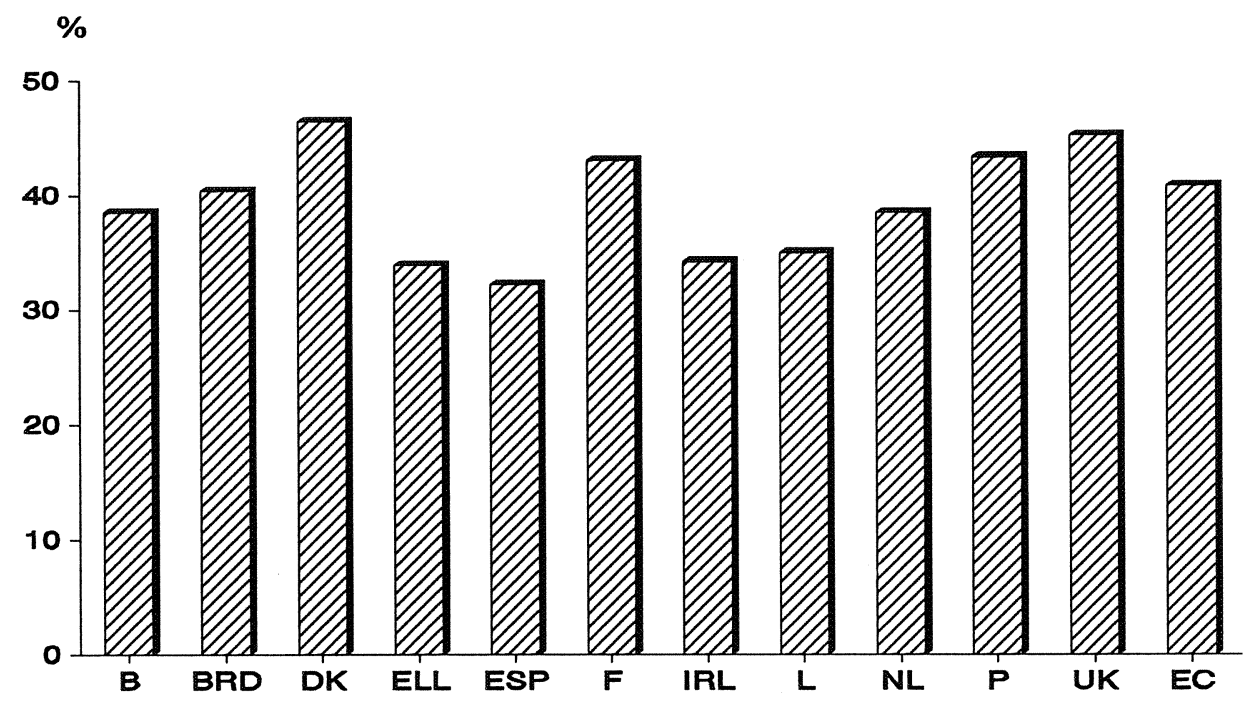

Source: EUROSTAT/ROA

Figure 4.2. Employment share of female professional, technical and related workers $(0 / 1)$ as a proportion of total employment in this occupational sector in 1991

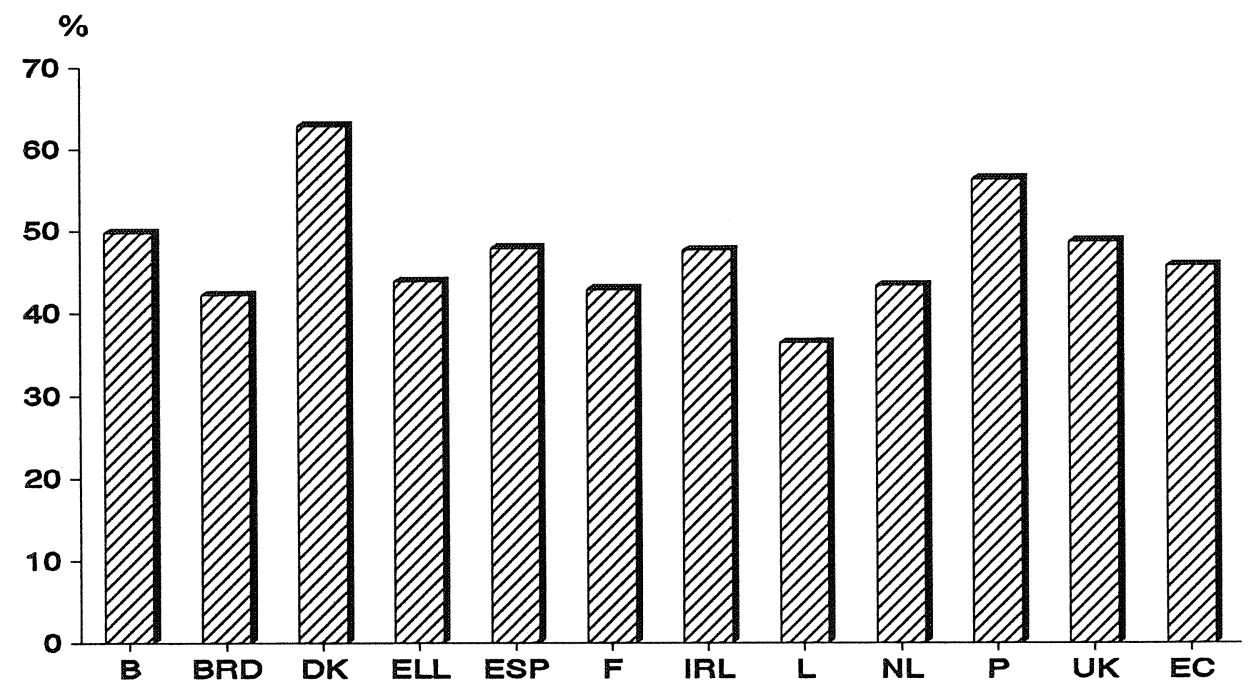

Source: EUROSTAT/ROA 
Figure 4.3. Employment share of female administrative and managerial workers (2) as a proportion of total employment in this occupational sector in 1991

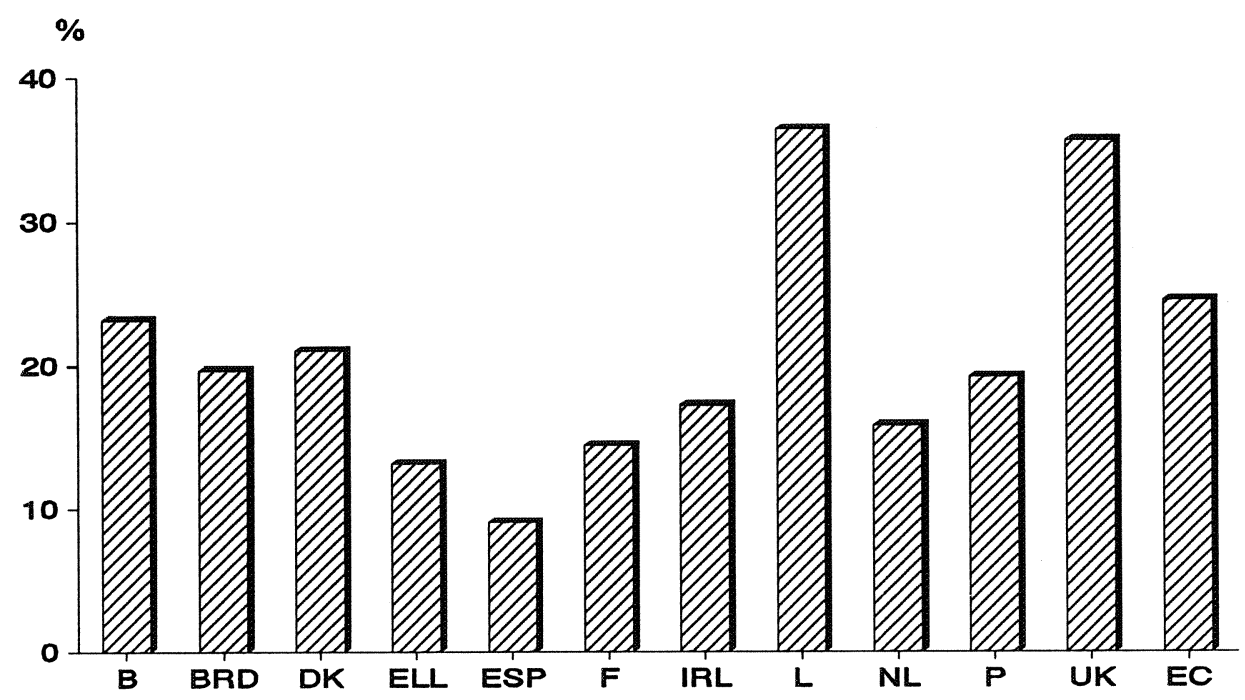

Source: EUROSTAT/ROA

Figure 4.4. Employment share of female clerical and related workers (3) as a proportion of total employment in this occupational sector in 1991

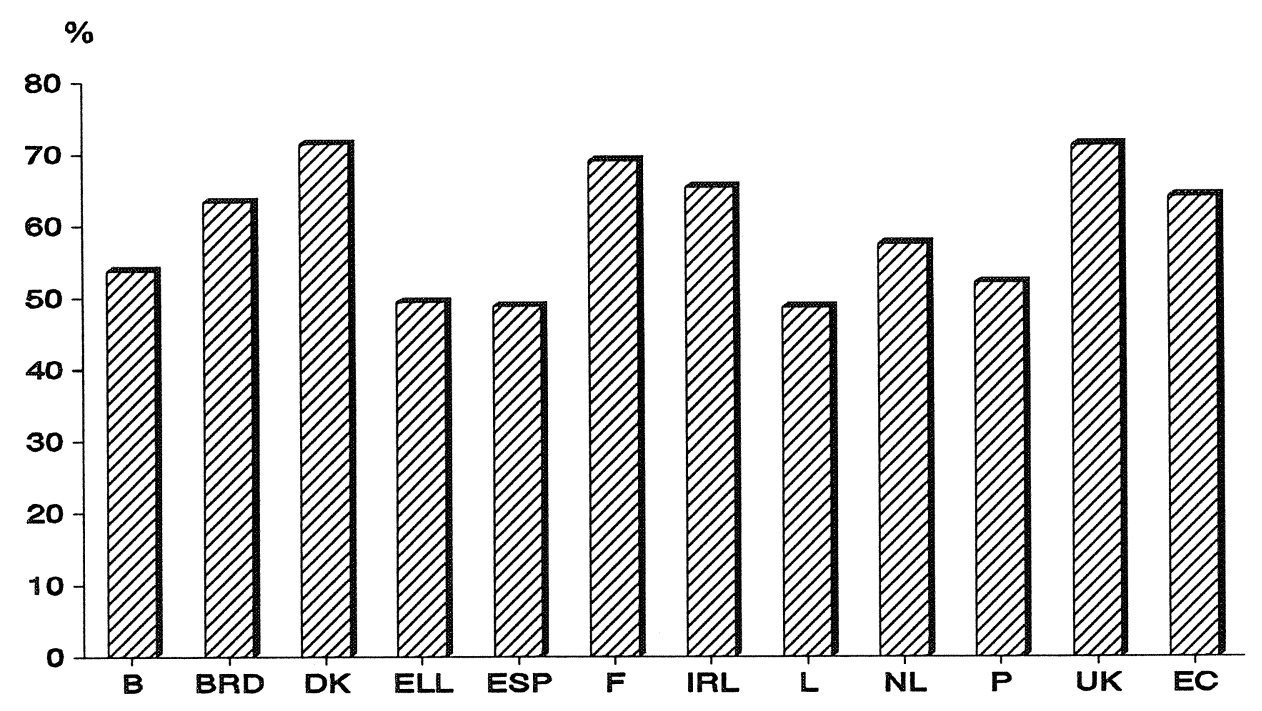

Source: EUROSTAT/ROA 
Figure 4.5. Employment share of female sales workers (4) as a proportion of total employment in this occupational sector in 1991

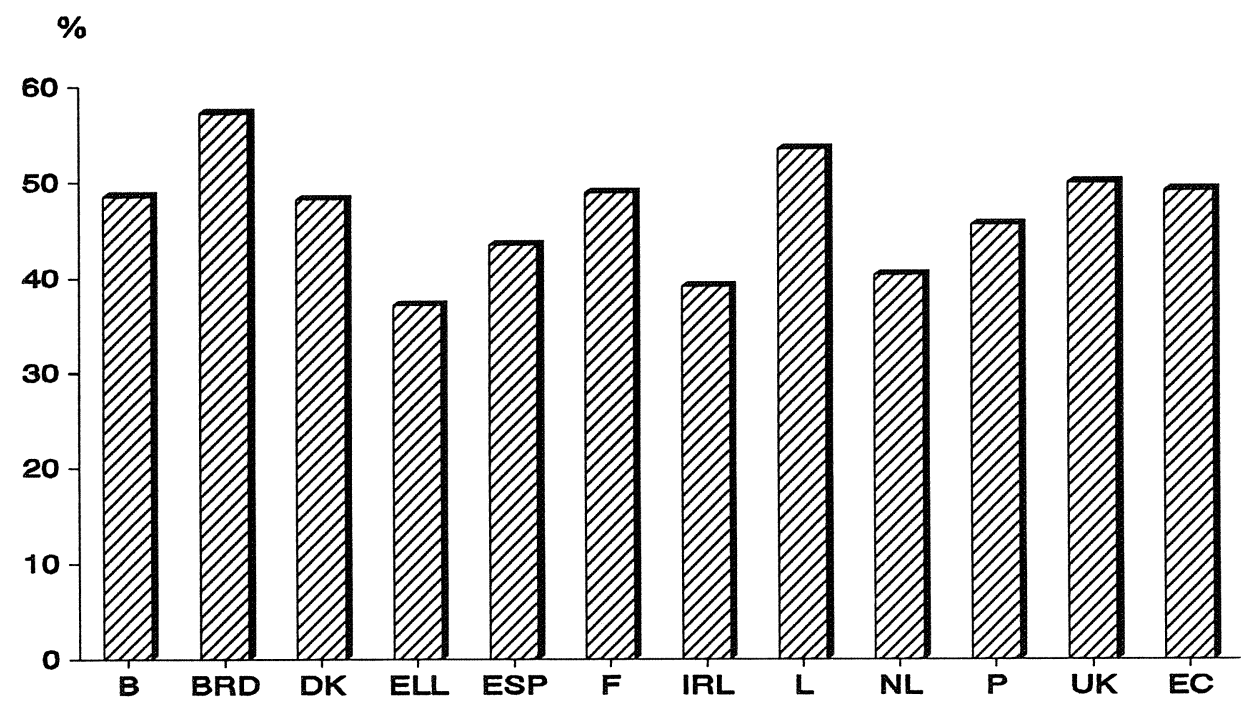

Source: EUROSTAT/ROA

Figure 4.6. Employment share of female service workers (5) as a proportion of total employment in this occupational sector in 1991

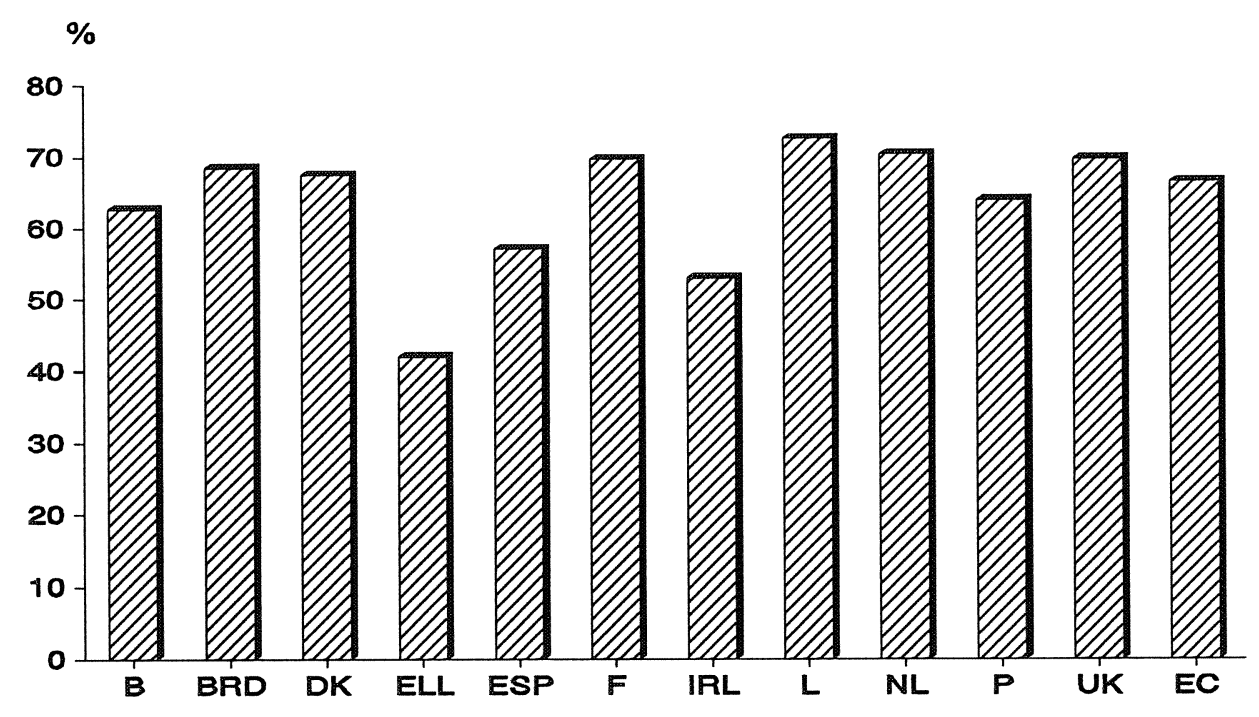

Source: EUROSTAT/ROA 
Figure 4.7. Employment share of female agricultural, animal husbandry and forestry workers, fishermen and hunters (6) as a proportion of total employment in this occupational sector in 1991

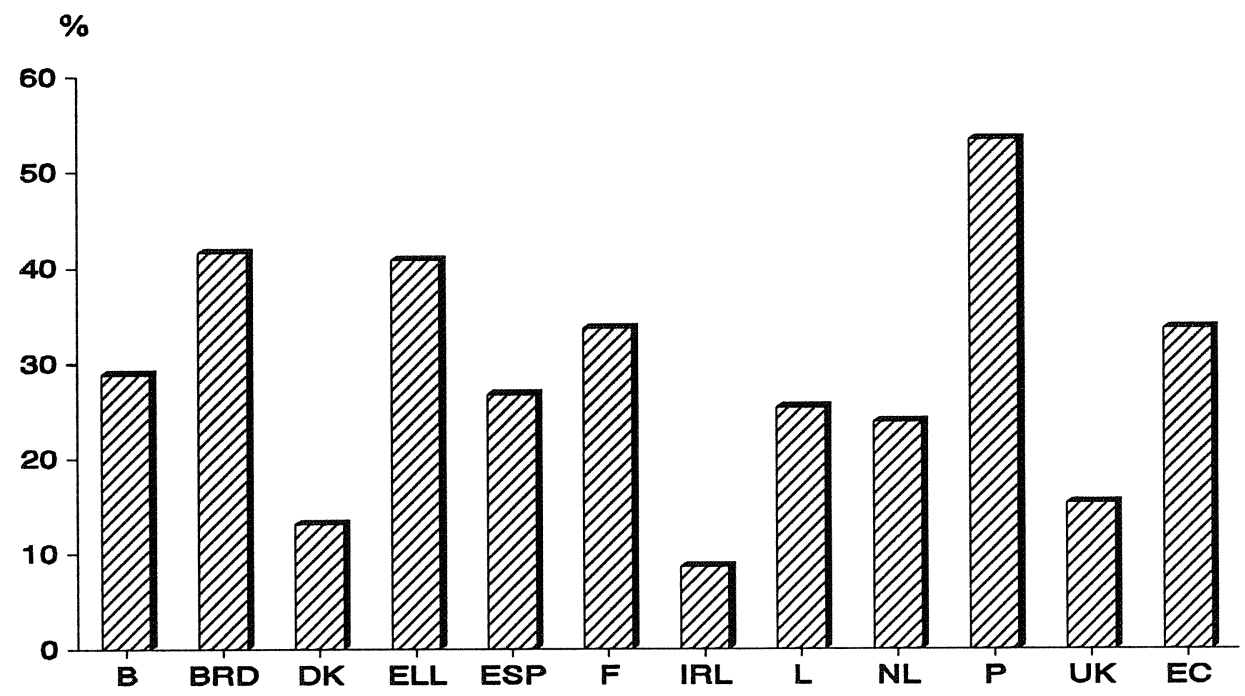

Source: EUROSTAT/ROA

Figure 4.8. Employment share of female production-related workers, transport equipment operators and labourers $(7 / 8 / 9)$ as a proportion of total employment in this occupational sector in 1991

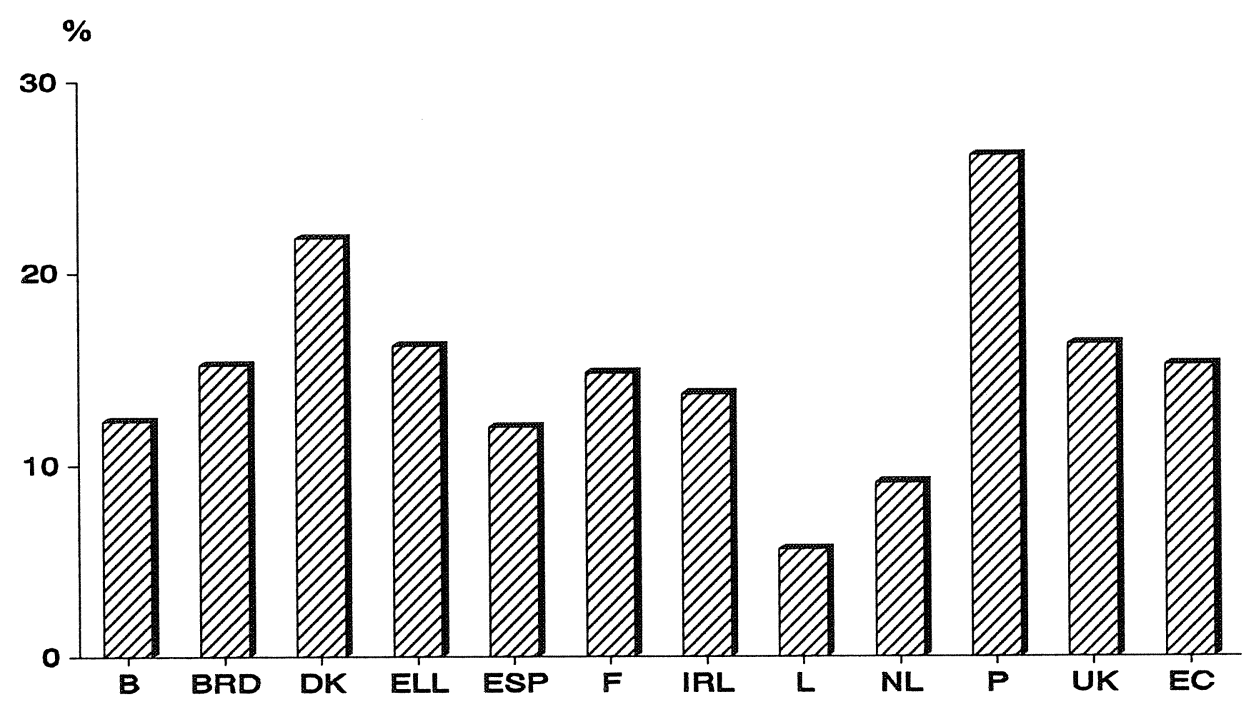

Source: EUROSTAT/ROA

Winners on the European labour market for women

With regard to the employment of women on the European labour market, three occupational sectors can be seen as winners. These are the 'professional, technical and related workers', 
'clerical and related workers' and 'administrative and managerial workers'. Remarkably, the occupational sector of 'administrative and managerial workers' can be seen as an occupational winner for women, whereas it was seen as an stable occupation (close to an occupational loser) for the total workforce (see chapter 1). The two other occupational sectors were also winners in chapter 1.

Table 4.1 shows that on average almost $20 \%$ of the female working population is employed in the occupational sector of 'professional, technical and related workers'. Belgium, Denmark and the Netherlands show especially high proportions of women working in this sector, whereas in Portugal relatively few women are employed in this occupational field.

Within the European Union the proportion of the female workforce in this occupational sector increased by an average of 2 percentage points in the period 1987-1991. Denmark shows the highest increase in the proportion of women employed in this occupational sector, with an increase of 5.1 percentage points. Greece, Spain and Portugal show increases in female employment which are higher than average, which indicates that these three countries are quickly catching up with the other Member States. The Netherlands also shows a relatively high increase in the proportion of women employed in this occupational sector, with an increase of 3.1 percentage points. Remarkably, in Ireland the proportion of women employed in this occupational sector decreased by 0.4 percentage points.

Table 4.1. Female professional, technical and related workers $(0 / 1)$ as a percentage of total female employment in 1991 and \%-points change in the period 1987-1991

\begin{tabular}{llcc}
\hline & $\begin{array}{l}1991 \\
\% \text { of female } \\
\text { employed }\end{array}$ & $\begin{array}{l}1991 \\
\% \text { of total } \\
\text { employment }\end{array}$ & $\begin{array}{c}\text { 1987-1991 } \\
\text { \%-point change } \\
\text { female employed }\end{array}$ \\
\hline Belgium & 29.3 & 22.6 & 1.0 \\
Federal Republic of Germany & 19.1 & 18.3 & 1.9 \\
Denmark & 35.3 & 26.1 & 5.1 \\
Greece & 17.0 & 13.1 & 3.2 \\
Spain & 17.0 & 11.4 & 2.7 \\
France & 18.8 & 18.9 & 0.6 \\
Ireland & 22.8 & 16.4 & -0.4 \\
Luxembourg & 13.2 & 12.7 & 3.0 \\
Netherlands & 27.2 & 24.2 & 3.1 \\
Portugal & 12.6 & 9.7 & 2.0 \\
United Kingdom & 19.7 & 18.4 & 2.0 \\
European Union & 19.9 & 17.8 & \\
\hline
\end{tabular}

Source: EUROSTAT/ROA

When we relate the proportion of the working women who work in this occupational sector to this sector's share of total national employment, as shown in the second column of table 4.1, we can see that in general women are slightly over-represented among the 'professional, 
technical and related workers'. France is the only country in which the percentage of women employed in this occupational sector lies below the sector's share of total employment. Denmark shows the largest (positive) gap between the percentage of women employed and the percentage of total employment.

Table 4.2 shows the second occupational winner on the labour market for women: the 'clerical and related workers'. On average $29.4 \%$ of all women work in this occupational sector. This means that this occupational sector is the most important in the occupational field of female employment. The Federal Republic of Germany and France have relatively high proportions of their female working populations employed in this occupational sector with $33 \%$ and $32.9 \%$, respectively. In Denmark, Greece, Spain and Portugal the proportions of the female workforce employed in this occupational sector are relatively small, at $24.7 \%, 17.6 \%, 20.2 \%$ and $16.5 \%$, respectively.

Table 4.2. Female clerical and related workers (3) as a percentage of total female employment in 1991 and \%-points change in the period 1987-1991

\begin{tabular}{llll}
\hline country & $\begin{array}{l}1991 \\
\% \text { of female } \\
\text { employed }\end{array}$ & $\begin{array}{l}1991 \\
\% \text { of total } \\
\text { employment }\end{array}$ & $\begin{array}{l}1987-1991 \\
\text { \%-point change } \\
\text { female employed }\end{array}$ \\
\hline Belgium & 28.0 & 20.0 & 1.5 \\
Federal Republic of Germany & 33.0 & 21.0 & 0.5 \\
Denmark & 24.7 & 16.1 & -2.4 \\
Greece & 17.6 & 12.0 & 3.1 \\
Spain & 20.2 & 13.3 & 4.4 \\
France & 32.9 & 20.5 & 1.3 \\
Ireland & 30.1 & 15.8 & 0.3 \\
Luxembourg & 36.5 & 26.2 & 3.6 \\
Netherlands & 28.0 & 18.8 & 1.6 \\
Portugal & 16.5 & 13.8 & 1.3 \\
United Kingdom & 30.9 & 19.6 & -0.3 \\
European Union & 29.4 & 18.8 & 0.8 \\
\hline
\end{tabular}

Source: EUROSTAT/ROA

On average the proportion of the female workforce employed in this occupational sector increased by 0.8 percentage points. The largest increases in the percentage of women employed in this occupational sector were realized by Greece and Spain with increases of 3.1 and 4.4 percentage points respectively. Portugal also shows an increase which is higher than average. Again this means that these three countries are catching up with the other Member States on this point. In the United Kingdom the proportion of the female workforce working in this sector decreased. However, the most striking feature in this table is the large decrease in the proportion of the Danish female workforce working in this occupational sector by 2.4 percentage points, as the proportion of Danish women employed in this occupational sector 
was already relatively low. As we saw in table 4.1 this decrease is to a large extent due to the increasing proportion of women in Denmark who are working as highly-skilled professional workers.

Table 4.2 also shows that there is a large gap between the percentage of women employed in this occupational sector and the percentage of the total workforce employed in this sector. Remarkably, Greece, Spain, and Portugal show the smallest gaps, whereas Ireland shows the largest gap. Other countries with a relatively large gap are the Federal Republic of Germany, France and the United Kingdom. In general it can be concluded that women are very much overrepresented in this occupational sector.

Although only $1.8 \%$ of the female European workforce is employed in the occupational sector of 'administrative and managerial workers' it can be regarded as an occupational winner with regard to female employment. Table 4.3 shows that in the United Kingdom and Belgium a relatively large proportion of the female working population is employed in this occupational sector, with $4.2 \%$ and $2.5 \%$, respectively. Greece, Spain, Portugal and especially France show, on the other hand, relatively low percentages of women employed in this occupational sector. In France only $0.1 \%$ of the female workforce is employed in this sector.

Table 4.3. Female administrative and managerial workers (2) as a percentage of total female employment in 1991 and \%-points change in the period 1987-1991

\begin{tabular}{lccc}
\hline country & $\begin{array}{l}1991 \\
\text { \% of female } \\
\text { employed }\end{array}$ & $\begin{array}{l}1991 \\
\text { \% of total } \\
\text { employment }\end{array}$ & $\begin{array}{l}\text { 1987-1991 } \\
\text { \%-point change } \\
\text { female employed }\end{array}$ \\
\hline Belgium & 2.5 & 4.2 & 1.0 \\
Federal Republic of Germany & 1.7 & 3.5 & -0.1 \\
Denmark & 2.1 & 4.7 & 1.1 \\
Greece & 0.7 & 1.7 & -0.1 \\
Spain & 0.5 & 1.9 & 0.3 \\
France & 0.1 & 0.4 & 0.3 \\
Ireland & 1.9 & 3.7 & - \\
Luxembourg & - & 1.0 & 0.6 \\
Netherlands & 1.9 & 4.7 & 0.4 \\
Portugal & 0.9 & 2.0 & 0.9 \\
United Kingdom & 4.2 & 5.4 & 0.3 \\
European Union & 1.8 & 3.1 & \\
\hline
\end{tabular}

\section{Source: EUROSTAT/ROA}

The proportion of women working in this occupational sector increased by an average of 0.3 percentage points in the period 1987-1991. Belgium, Denmark and the United Kingdom show the highest increases with 1 percentage point, 1.1 percentage points and 0.9 percentage points, respectively, whereas the Federal Republic of Germany and Greece show a slight decrease in the proportion of the female workforce employed in this occupational sector. 
In all countries the percentages of women employed in this occupational sector are much lower than the sector's share in total employment. Denmark and the Netherlands in particular and, to a lesser degree, also Belgium, the Federal Republic of Germany and Ireland, show relatively large (negative) gaps.

\section{Losers on the European labour market for women}

In occupational structure of female employment we can also identify three occupational losers at European level. These are the occupational sectors of 'agricultural, animal husbandry and forestry workers, fishermen and hunters', 'production and related workers, transport equipment operators and labourers' and 'service workers'. For the total workforce, the occupational sector of 'service workers' had been identified as a stable occupational sector (see chapter 1), whereas the two other occupational sectors also had been identified as occupational losers.

Table 4.4 shows the first occupational loser on the labour market for women in the European Union. On average $4.7 \%$ of the female workforce is employed in the occupational sector of 'agricultural, animal husbandry and forestry workers, fishermen and hunters'. Most remarkable is the very large proportion of the female working population employed in this occupational sector in Spain and Portugal. In Spain 1 out of 4 women is employed in this occupational sector, whereas in the United Kingdom the sector employs less than 1 out of 100 women. Other countries with a relatively small percentage of the female workforce employed in this occupational sector are Denmark and Belgium.

On average the proportion of the female workforce employed in this occupational sector decreased by 1.5 percentage points in the period 1987-1991. Greece and Portugal show the largest decreases, by 8.5 and 6.6 percentage points, respectively. Another country with a relatively large decrease in the proportion of the female working population in this sector is Spain, with 3.5 percentage points. Again this is an indication that these three countries are catching up with the other Member States. Denmark is the only country that saw a small increase in the proportion of the female workforce employed in this occupational sector. Belgium, the Netherlands and the United Kingdom show decreases that are much lower than average.

The table also shows that on average the percentage of women employed in this occupational sector is slightly lower than the share of the sector in total employment. Greece and Portugal are the only countries showing higher proportions of the female workforce employed in this occupational sector than the proportions of the total workforce working in this sector. Denmark and Ireland show relatively large (negative) gaps between the percentage of women employed in this occupational sector and the percentage of total employment. 
Table 4.4. Female agricultural, animal husbandry and forestry workers, fishermen and hunters (6) as a percentage of total female employment in 1991 and \%-points change in the period 1987-1991

\begin{tabular}{lccc}
\hline country & $\begin{array}{l}\text { 1991 } \\
\text { \% of female } \\
\text { employed }\end{array}$ & $\begin{array}{l}\text { 1991 } \\
\text { \% of total } \\
\text { employment }\end{array}$ & $\begin{array}{l}\text { 1987-1991 } \\
\text { \%-point change } \\
\text { female employed }\end{array}$ \\
\hline Belgium & & & -0.4 \\
Federal Republic of Germany & 2.0 & 2.7 & -1.5 \\
Denmark & 3.6 & 3.5 & 0.1 \\
Greece & 1.2 & 4.2 & -8.5 \\
Spain & 25.3 & 21.0 & -3.5 \\
France & 8.7 & 10.4 & -1.3 \\
Ireland & 4.9 & 6.3 & -1.1 \\
Luxembourg & 3.2 & 12.8 & 0.0 \\
Netherlands & 3.0 & 4.2 & -0.3 \\
Portugal & 2.7 & 4.4 & -6.6 \\
United Kingdom & 18.9 & 15.4 & -0.3 \\
European Union & 0.7 & 2.0 & -1.5 \\
\hline
\end{tabular}

Source: EUROSTAT/ROA

Table 4.5 shows the second occupational loser in female employment. The table shows that $12 \%$ of all women employed in the European Union work in the occupational sector of 'production and related workers, transport equipment operators and labourers'. The most striking feature is that Portugal shows the highest proportion of the female working population employed in this occupational sector: $22 \%$. Other countries with a relatively high proportion of the female workforce in this sector are Denmark, Greece and Spain, with $14.8 \%, 14.8 \%$ and $14.1 \%$, respectively. In the Netherlands an extremely low percentage of the female workforce is employed in this occupational sector.

The proportion of the female workforce employed in this occupational sector decreased by an average of 0.8 percentage points. Belgium and the Netherlands show the largest decreases in the proportion of the female working population employed in this occupational sector, with 2 and 2.2 percentage points respectively. Remarkably, in Greece and Portugal the proportion of the female workforce slightly increased by 0.2 and 0.3 percentage points, respectively.

Comparing the percentage of the female workforce employed in this occupational sector and the employment share of this sector in the total workforce, a very large (negative) gap can be identified: women are heavily under-represented in this occupational sector. In Denmark this gap is extremely large, whereas it is relatively 'small' for Portugal. 
Table 4.5. Female production and related workers, transport equipment operators and labourers $(7 / 8 / 9)$ as a proportion of total female employment in 1991 and \%-points change in the period 1987 1991

\begin{tabular}{llll}
\hline & $\begin{array}{l}1991 \\
\% \text { of female } \\
\text { employed }\end{array}$ & $\begin{array}{l}1991 \\
\% \text { of total } \\
\text { employment }\end{array}$ & $\begin{array}{l}1987-1991 \\
\text { \%-point change } \\
\text { female employed }\end{array}$ \\
\hline Belgium & 10.0 & 31.2 & -2.0 \\
Federal Republic of Germany & 13.0 & 34.7 & -0.6 \\
Denmark & 14.8 & 31.5 & -0.8 \\
Greece & 14.8 & 30.9 & 0.2 \\
Spain & 14.1 & 38.0 & -0.8 \\
France & 10.6 & 31.1 & -0.8 \\
Ireland & 11.5 & 28.8 & -1.2 \\
Luxembourg & 5.4 & 33.4 & -0.5 \\
Netherlands & 5.7 & 24.4 & -2.2 \\
Portugal & 22.0 & 36.6 & 0.3 \\
United Kingdom & 10.5 & 29.3 & -1.1 \\
European Union & 12.0 & 32.3 & -0.8 \\
\hline
\end{tabular}

Source: EUROSTAT/ROA

Table 4.6 shows the third occupational loser for female employment at the European level. On average $20 \%$ of all employed women are active in the occupational sector of 'service workers'. This means that this occupational sector is the second most important occupational field for female employment, after the clerical-related workers. Spain shows a relatively high percentage of the female working population employed in this occupational sector, at $24.2 \%$, whereas Belgium, the Federal Republic of Germany, Denmark and Greece show relatively low percentages of $16.9 \%, 16.4 \%, 13.3 \%$ and $11.6 \%$, respectively.

On average the proportion of the female working population employed in this occupational sector decreased by 0.7 percentage points. Denmark and Spain show the highest decreases, of 2.1 and 1.8 percentage points, respectively. Remarkably, four countries did not show a decrease: Belgium, the Federal Republic of Germany, Greece and Ireland. Ireland even saw an increase of 1.5 percentage points.

When relating the percentage of the female workforce employed in this occupational to the percentage of the total working population that is employed in this sector, we can see that women are considerably over-represented in this occupational sector. From the table we can see that Denmark and especially Greece show a relatively small (positive) gap, whereas Spain and the Netherlands show a relatively wide gap. 
Table 4.6. Female service workers (5) as a proportion of total female employment in 1991 and \%-points change in the period 1987-1991

\begin{tabular}{llll}
\hline country & $\begin{array}{l}1991 \\
\text { \% of female } \\
\text { employed }\end{array}$ & $\begin{array}{l}1991 \\
\% \text { of total } \\
\text { employment }\end{array}$ & $\begin{array}{l}\text { 1987-1991 } \\
\text { \%-point change } \\
\text { female employed }\end{array}$ \\
\hline Belgium & 16.9 & 10.4 & 0.2 \\
Federal Republic of Germany & 16.4 & 9.7 & 0.0 \\
Denmark & 13.3 & 9.2 & -2.1 \\
Greece & 11.6 & 9.3 & 0.0 \\
Spain & 24.2 & 13.7 & -1.8 \\
France & 22.6 & 14.0 & -0.5 \\
Ireland & 18.3 & 11.8 & 1.5 \\
Luxembourg & 28.4 & 13.7 & -3.5 \\
Netherlands & 22.8 & 12.5 & -1.4 \\
Portugal & 18.5 & 12.6 & -0.1 \\
United Kingdom & 21.5 & 14.0 & -1.0 \\
European Union & 20.0 & 12.3 & -0.7 \\
\hline
\end{tabular}

Source: EUROSTAT/ROA

\section{Stable occupations}

The occupational sector of female 'sales workers' stayed relatively stable in the period 19871991. Table 4.7 shows that on average $12.2 \%$ of the female working population is employed in this occupational sector. Especially in Spain a high proportion $(15.3 \%)$ of the female working population is employed in this occupational sector whereas Denmark, France and Portugal show relatively small proportions of $8.7 \%, 10.1 \%$ and $10.5 \%$, respectively.

There was no change in the overall proportion of the female European workforce employed in this occupational sector in the period 1987-1991. However, in four Member States the proportion of the female workforce in this occupational sector increased, whereas in the six other Member States this proportion decreased. The greatest decreases of the proportion of women that work in this occupational sector were seen in Belgium, Denmark, Spain and the Netherlands. Greece and Portugal, on the other hand show the highest increases in the proportion of women working in this occupational field.

On average women are slightly over-represented in this occupational sector. The Federal Republic of Germany and Spain show a relatively wide gap between the percentage of the female workforce employed in this occupational sector and the percentage of total employment, whereas Denmark, the Netherlands and Portugal show only a very small gap. 
Table 4.7. Female sales workers (4) as a proportion of total female employment in 1991 and \%-points change in the period 1987-1991

\begin{tabular}{lccc}
\hline country & $\begin{array}{l}\text { 1991 } \\
\text { \% of female } \\
\text { employed }\end{array}$ & $\begin{array}{l}1991 \\
\text { \% of total } \\
\text { employment }\end{array}$ & $\begin{array}{l}\text { 1987-1991 } \\
\text { \%-point change } \\
\text { female employed }\end{array}$ \\
\hline Belgium & 11.4 & 9.0 & -1.4 \\
Federal Republic of Germany & 13.2 & 9.4 & -0.2 \\
Denmark & 8.7 & 8.3 & -1.0 \\
Greece & 13.1 & 11.9 & 2.1 \\
Spain & 15.3 & 11.3 & -1.2 \\
France & 10.1 & 8.9 & 0.7 \\
Ireland & 12.2 & 10.7 & 0.6 \\
Luxembourg & 13.4 & 8.8 & 0.7 \\
Netherlands & 11.6 & 11.1 & -1.1 \\
Portugal & 10.5 & 10.0 & 1.6 \\
United Kingdom & 12.4 & 11.3 & -0.2 \\
European Union & 12.2 & 10.1 & 0.0 \\
\hline
\end{tabular}

Source: EUROSTAT/ROA

\subsection{Skill levels and training in the European labour market for women}

\section{Introduction}

As already noted in chapter 2, the quality of the working population is an important determinant of the position of the European Union in international competition. The position of women in this working population has become increasingly important in the last decade. Figure 4.1 showed that in 1991 women made up $41 \%$ of the total workforce. This makes it very interesting to analyze the changes in the skill levels of the European female working population in the various Member States, and to compare them with the skill levels of the total workforce. Once again we distinguish between worker's educational background and their participation in further training. Figure 4.9 shows that apart from the great differences between the average educational level of the various EU countries, there are also differences between the average educational level of women and the total average educational level in the various Member States ${ }^{18}$. On average the educational level of the female working population is slightly lower than that of the total workforce. Denmark shows the highest educational level of the female working population, whereas the Portuguese female workforce has the lowest educational level.

If we compare the average educational level of women to that of the whole workforce, the low average educational level of women in the Federal Republic of Germany is most striking. Whereas the Federal Republic of Germany shows the highest average educational level for

18. Again France had to be excluded from the skill-level analysis, as for this country there were only data available for 1988 and 1989. 
maleworkers, it is only the fifth in rank where the average educational level of the female working population is concerned. It is also quite remarkable that in Belgium, Spain, Ireland and Portugal the average educational level of women is higher than the total average educational level.

We will now analyze first the changes in the educational level of the female working population in the various EU countries, differentiating between occupational sectors. We will also show the shifts in the educational structure of the employed women in the period 1988-1991. We will then analyze women's participation in training, again differentiating by occupational sector, and relate this to the total participation in training.

From table 4.9 it can be seen that in the European Union the majority of women are educated to a lower to intermediate skill level. However, as figure 4.9 shows, the differences between the various Member States are rather great. Again the position of Portugal is very remarkable. Of the female working population in this country, $70 \%$ are unskilled. This is almost $30 \%$ higher than Spain which is the second in rank. However, this outcome does not differ much from the situation of the whole workforce, as seen in table 2.1. The educational level of women in Greece and Spain is in line with the educational structure of total employment in these two countries, with relatively high employment shares for unskilled women. However, the skill gap between women in these first three countries and the other Member States is very great.

Figure 4.9. Educational level of the working population by gender in 1991

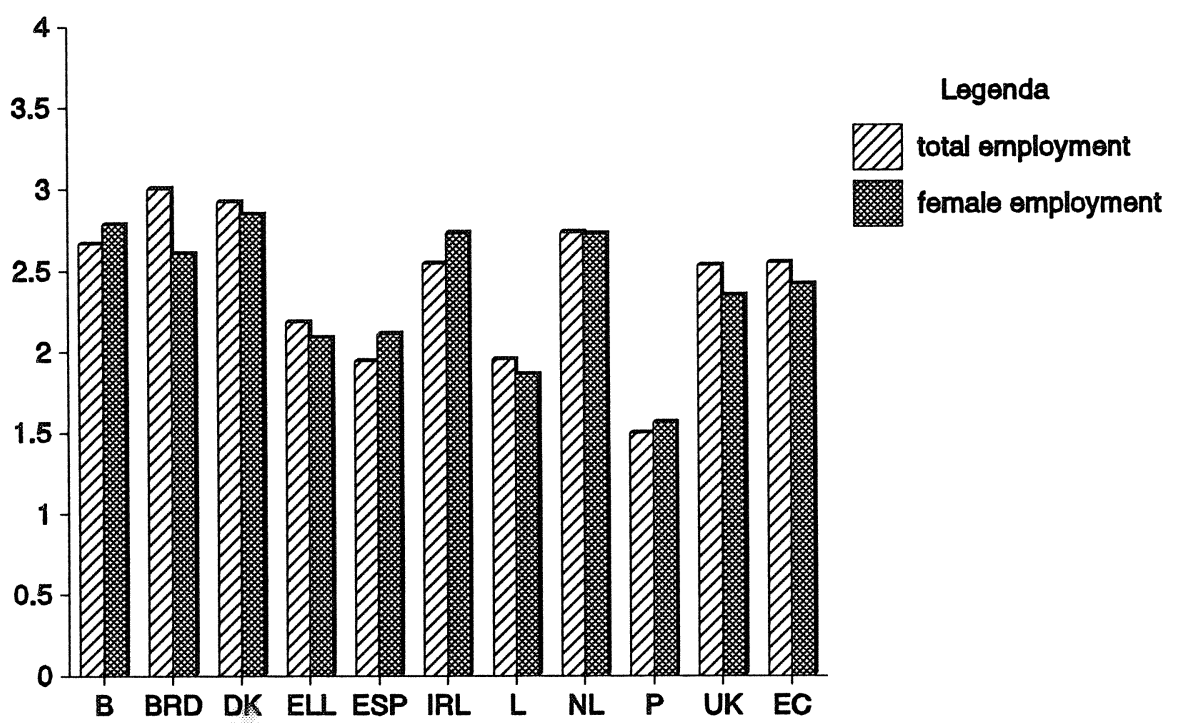

$\begin{array}{llll}1 & \text { unskilled } & 2 & \text { lower skilled } \\ 3 & \text { intermediate skilled } & 4 & \text { highly skilled }\end{array}$


When looking to the lower skilled women, we can again see a very high percentage for the United Kingdom. The percentage is more than twice as high as that of Denmark, which is the second in rank. Another remarkable feature is the very low percentage of lower skilled women in Greece, where a much higher percentage was expected.

On the intermediate level the high percentages for the Federal Republic of Germany, Denmark, Ireland and the Netherlands are most remarkable. In all these countries more than $40 \%$ of all working woman have an intermediate skill level.

At the highly-skilled level, the relatively high percentages of highly skilled women in Belgium and Greece are striking. It is very remarkable that the percentage of highly skilled women in Greece lies well above the European average. Other countries with relatively high percentages of highly skilled women are Ireland and Denmark.

Compared to the educational structure of total employment, as shown in table 2.1 , we can see that relatively many women are lower skilled. The percentages at the other educational levels all lie below the percentages for total employment in the European Union. The most striking differences between the two tables are the relatively small percentages of unskilled women in Ireland and Spain, the relatively low percentage of lower skilled women and relatively high percentage of intermediate skilled women in Ireland, the relatively low percentage of intermediate skilled women in the United Kingdom, the relatively high percentages of highly skilled women in Belgium and Spain, and the relatively low percentage of highly skilled women in the Federal Republic of Germany.

Table 4.9. Educational levels of female European employment (total) in 1991

\begin{tabular}{lcccc}
\hline unskilled & $\begin{array}{c}\text { lower } \\
\text { skilled } \\
\text { country }\end{array}$ & $\%$ & $\begin{array}{c}\text { intermediate } \\
\text { skilled } \\
\%\end{array}$ & $\begin{array}{c}\text { highly } \\
\text { skilled } \\
\%\end{array}$ \\
\hline Belgium & $\%$ & 24.1 & 31.6 & 30.6 \\
Federal Republic of Germany & 13.2 & 19.0 & 57.6 & 12.0 \\
Denmark & 1.9 & 29.4 & 46.9 & 21.3 \\
Greece & - & 5.9 & 25.4 & 20.1 \\
Spain & 40.5 & 23.0 & 18.8 & 16.9 \\
France & 41.2 & 19.6 & 41.7 & 24.7 \\
Ireland & & 36.9 & 14.5 & 7.9 \\
Luxembourg & 10.1 & 26.6 & 42.3 & 20.7 \\
Netherlands & 37.2 & 11.8 & 7.1 & 10.4 \\
Portugal & 9.9 & 65.5 & 13.9 & 15.6 \\
United Kingdom & 70.0 & 34.0 & 32.9 & 15.7 \\
European Union & - & & &
\end{tabular}


Table 4.10 shows the educational level of 'professional, technical and related workers'. The modal woman working in this occupational sector is educated to a highly skilled level. The table shows that on average only $1 \%$ of the women employed in this occupational sector is unskilled. Greece, Spain and Portugal show the highest employment shares of unskilled women in this occupational sector.

The table also shows that the proportion of women in this occupational sector educated only to the lower skilled level is relatively small (on average only $12.5 \%$ ). Remarkably, Denmark and the United Kingdom show percentages of lower skilled female workers which are well above average, whereas all other Member States show percentages well under the average. In Greece only $1.2 \%$ of all women employed in this occupational sector are lower skilled.

Women educated to the intermediate skill level have an average employment share of $26.9 \%$. Remarkably, the Federal Republic of Germany, Denmark and the Netherlands show high percentages of intermediate skilled women in this occupational sector, whereas Greece, Spain, Portugal and the United Kingdom show relatively low percentages.

Table 4.10. Skill levels of female professional, technical and related workers $(0 / 1)$ in 1991

\begin{tabular}{|c|c|c|c|c|}
\hline country & $\begin{array}{l}\text { unskilled } \\
\%\end{array}$ & $\begin{array}{l}\text { lower } \\
\text { skilled } \\
\%\end{array}$ & $\begin{array}{l}\text { intermediate } \\
\text { skilled } \\
\quad \%\end{array}$ & $\begin{array}{c}\text { highly } \\
\text { skilled } \\
\%\end{array}$ \\
\hline Belgium & 0.8 & 5.0 & 19.9 & 73.7 \\
\hline Federal Republic of Germany & 0.4 & 5.7 & 42.6 & 40.6 \\
\hline Denmark & - & 17.0 & 34.4 & 48.2 \\
\hline Greece & 2.5 & 1.2 & 11.1 & 82.7 \\
\hline Spain & 4.1 & 5.6 & 14.9 & 75.4 \\
\hline \multicolumn{5}{|l|}{ France } \\
\hline Ireland & - & - & 21.0 & 73.5 \\
\hline Luxembourg & - & 25.7 & 28.4 & 40.5 \\
\hline Netherlands & 0.6 & 4.7 & 40.2 & 54.2 \\
\hline Portugal & 6.8 & 7.9 & 11.0 & 73.3 \\
\hline United Kingdom & - & 26.9 & 12.5 & 57.5 \\
\hline European Union & 1.0 & 12.5 & 26.5 & 55.6 \\
\hline
\end{tabular}

Source: EUROSTAT/ROA

Most striking, however, is that women in Greece and Spain show the highest educational level in this occupational sector. The two countries have employment shares of highly skilled women in this occupational sector of over $75 \%$. Other countries with relatively high employment shares of highly skilled women are Belgium, Ireland and Portugal. Remarkably, the Federal Republic of Germany and Denmark show relatively low percentages of highly skilled women in this occupational sector. 
Compared to the total workforce in this occupational sector (see table 2.2) we see that in this sector women are on average less educated than men. Especially in the Federal Republic of Germany and the Netherlands the percentages of intermediate skilled women are much higher than the same percentages for the total workforce in the sector. The percentage of highly skilled women in the Federal Republic of Germany lies very much below the percentage of the total highly skilled in this occupational sector. The relatively high percentage of highly skilled women in this sector in Portugal is also very remarkable.

The skill levels of female 'administrative and managerial workers' are given in table 4.11. The average employment share of unskilled women in this occupational sector amounts to $2.5 \%$. However, in Portugal more than half of the very small group of women employed in this occupational sector are unskilled. Spain is second in rank with $23 \%$. In the other Member States the majority of female workers are educated to an intermediate or highly skilled level.

When looking at the lower skilled women in this occupational sector, the position of the United Kingdom is most striking. In this country $54 \%$ of all women employed as 'administrative and managerial workers' are lower skilled, whereas in Denmark, the second in rank, only $19.2 \%$ are lower skilled. The Federal Republic of Germany and the Netherlands show relatively small employment shares of lower skilled women in this occupational sector.

The table shows that the Federal Republic of Germany and Denmark have high proportions of intermediate skilled female 'administrative and managerial workers ' $51.5 \%$ and $44.7 \%$ respectively, whereas the European average is $30.7 \%$. Ireland and the Netherlands also show relatively large proportions of intermediate skilled women in this occupational sector. In the United Kingdom and in Portugal the employment share of intermediate skilled women is relatively small. In Portugal the number of intermediate skilled women does not even reach the threshold value.

On average $27.4 \%$ of all women employed in this occupational sector are highly educated. Belgium, Denmark, Greece, Ireland and the Netherlands show especially high proportions of highly skilled women in this occupational sector. The United Kingdom is the only country with a relatively low proportion of highly skilled women.

Compared to the total workforce in this occupational sector (see table 2.3), we can see that again women are on average less educated than men. The percentage of lower skilled women in this occupational sector lies far above the percentage shown in table 2.3, whereas the percentage of highly skilled women lies well below the percentage of highly skilled workers of the total workforce in this occupational sector. Especially in the Federal Republic of Germany the percentage of highly skilled women is very low. 
Table 4.11. Skill levels of female administrative and managerial workers (2) in 1991

\begin{tabular}{|c|c|c|c|c|}
\hline country & $\begin{array}{l}\text { unskilled } \\
\%\end{array}$ & $\begin{array}{l}\text { lower } \\
\text { skilled } \\
\%\end{array}$ & $\begin{array}{l}\text { intermediate } \\
\text { skilled } \\
\quad \%\end{array}$ & $\begin{array}{l}\text { highly } \\
\text { skilled } \\
\%\end{array}$ \\
\hline Belgium & 9.2 & 17.6 & 35.6 & 37.0 \\
\hline Federal Republic of Germany & - & 7.9 & 51.5 & 30.9 \\
\hline Denmark & - & 19.2 & 44.7 & 33.7 \\
\hline Greece & - & - & 32.1 & 44.9 \\
\hline Spain & 23.0 & 19.2 & 25.4 & 31.9 \\
\hline \multicolumn{5}{|l|}{ France } \\
\hline Ireland & - & - & 46.5 & 40.8 \\
\hline Luxembourg & - & - & - & - \\
\hline Netherlands & 5.7 & 9.7 & 37.8 & 46.6 \\
\hline Portugal & 51.7 & 17.8 & - & 26.7 \\
\hline United Kingdom & - & 54.0 & 21.1 & 22.1 \\
\hline European Union & 2.5 & 34.9 & 30.7 & 27.4 \\
\hline
\end{tabular}

Source: EUROSTAT/ROA

Table 4.12 focuses on the female 'clerical workers' in the European Union. The average woman in this occupational sector is educated to an intermediate skill level. On average, the unskilled women only have an employment share of $2.6 \%$. Most striking are the relatively high percentages of unskilled women in Portugal, Spain and especially the Netherlands with $29.4 \%$, $9.9 \%$ and $5.5 \%$, respectively.

Lower skilled women have an average employment share of $36.3 \%$ in this occupational sector. It is no surprise to see that the United Kingdom again has the highest proportion of lower skilled female clerical workers, with $73.9 \%$. The Federal Republic of Germany in particular, but also Ireland and the Netherlands, show relatively small employment shares of lower skilled women in this occupational sector.

As noted before, the average woman in this occupational sector is educated to the intermediate skill level. In 6 out of 9 Member States more than half of all women employed in this occupational sector are intermediate skilled. In the Federal Republic of Germany and Denmark the rate is even higher than $70 \%$, and in Greece and Ireland over $65 \%$ of the female workforce in this occupational field is intermediate skilled. The United Kingdom, however, shows an extremely low percentage of intermediate skilled women.

On average $8.4 \%$ of all women in this occupational sector are highly skilled. It is most striking that Belgium and Greece show the highest proportions of highly skilled women in this sector, with $22 \%$ and $22.9 \%$, respectively. Other countries with a relatively large employment share of highly skilled women are Spain $(15.1 \%)$, Ireland $(14.8 \%)$ and the Netherlands $(13.6 \%)$. The Federal Republic of Germany, Portugal and the United Kingdom show relatively small proportions of highly skilled women in this sector. 
A comparison to the total workforce in this occupational sector (see table 2.4) makes it clear that low skilled women are over-represented and highly skilled women are under-represented.

Table 4.12. Skill levels of female clerical and related workers (3) in 1991

\begin{tabular}{|c|c|c|c|c|}
\hline country & $\begin{array}{l}\text { unskilled } \\
\text { \% }\end{array}$ & $\begin{array}{l}\text { lower } \\
\text { skilled } \\
\%\end{array}$ & $\begin{array}{l}\text { intermediate } \\
\text { skilled } \\
\quad \%\end{array}$ & $\begin{array}{l}\text { highly } \\
\text { skilled } \\
\%\end{array}$ \\
\hline Belgium & 3.6 & 22.4 & 51.8 & 22.0 \\
\hline Federal Republic of Germany & 0.6 & 12.2 & 71.8 & 6.3 \\
\hline Denmark & - & 17.1 & 72.4 & 10.1 \\
\hline Greece & 3.2 & 3.9 & 67.3 & 22.9 \\
\hline Spain & 9.9 & 25.0 & 49.9 & 15.1 \\
\hline \multicolumn{5}{|l|}{ France } \\
\hline Ireland & - & 14.7 & 68.1 & 14.8 \\
\hline Luxembourg & 9.3 & 56.4 & 27.0 & 6.9 \\
\hline Netherlands & 5.5 & 28.3 & 52.5 & 13.6 \\
\hline Portugal & 29.4 & 38.7 & 26.9 & 4.4 \\
\hline United Kingdom & - & 73.9 & 16.7 & 5.5 \\
\hline European Union & 2.6 & 36.2 & 47.9 & 8.4 \\
\hline
\end{tabular}

Source: EUROSTAT/ROA

Table 4.13 shows the skill levels of female 'sales workers'. Again the percentages of unskilled women in Greece, Spain and Portugal are very high, whereas the proportion of unskilled women in Denmark and the United Kingdom is very small.

The lower skilled women comprise the largest group, with an average employment share of $39.4 \%$. It is remarkable that in the United Kingdom more than three quarters of all women employed in this occupational sector are lower skilled. Another country with a relatively large employment share of lower skilled women is the Netherlands (41.7\%). The Federal Republic of Germany and Greece show surprisingly small proportions of lower skilled women employed in this occupational sector, whereas the small proportion of Portugal is in line with expectations.

The proportion of intermediate skilled women in this occupational sector is slightly smaller than for low skilled women. On average intermediate skilled women have an employment share of $37.1 \%$. In the Federal Republic of Germany some $70 \%$ of all women employed in this occupational sector are intermediate skilled. Other countries in which intermediate skilled women have a relatively high employment share are Denmark, Greece and Ireland. Spain, Portugal and the United Kingdom show relatively low proportions of intermediate skilled women in this occupational sector.

Highly skilled women have an average employment share of $4.3 \%$ in this occupational sector. Belgium, Greece and Ireland show relatively high proportions of highly skilled women with $10.5 \%, 7.2 \%$ and $9.3 \%$, respectively. Only Portugal shows a relatively small proportion of highly skilled women in this occupational sector. 
Table 4.13. Skill levels of female sales workers (4) in 1991

\begin{tabular}{|c|c|c|c|c|}
\hline country & $\begin{array}{l}\text { unskilled } \\
\%\end{array}$ & $\begin{array}{l}\text { lower } \\
\text { skilled } \\
\%\end{array}$ & $\begin{array}{l}\text { intermediate } \\
\text { skilled } \\
\quad \%\end{array}$ & $\begin{array}{l}\text { highly } \\
\text { skilled } \\
\%\end{array}$ \\
\hline Belgium & 16.6 & 38.3 & 34.4 & 10.5 \\
\hline Federal Republic of Germany & 0.7 & 15.4 & 70.0 & 3.6 \\
\hline Denmark & - & 33.5 & 58.0 & 4.0 \\
\hline Greece & 33.1 & 11.1 & 44.5 & 7.2 \\
\hline Spain & 49.0 & 32.2 & 15.3 & 3.5 \\
\hline \multicolumn{5}{|l|}{ France } \\
\hline Ireland & 8.9 & 30.9 & 50.2 & 9.3 \\
\hline Luxembourg & 48.0 & 42.7 & 6.7 & - \\
\hline Netherlands & 15.7 & 41.7 & 37.7 & 4.9 \\
\hline Portugal & 72.9 & 18.4 & 6.7 & 1.8 \\
\hline United Kingdom & - & 77.3 & 12.2 & 4.6 \\
\hline European Union & 13.5 & 39.4 & 37.1 & 4.3 \\
\hline
\end{tabular}

Source: EUROSTAT/ROA

Compared to the total workforce in this occupational sector (see table 2.5) it is again obvious that lower skilled women are over-represented and that highly skilled women are underrepresented in this occupational sector.

Table 4.14 shows that the skill level of the modal female 'service workers' is relatively low. On average $20.5 \%$ of all women employed in this occupational sector are unskilled. Not surprisingly, Spain, Greece and Portugal again show the highest employment shares of unskilled women: $59.4 \%, 65.3 \%$ and $90.9 \%$, respectively. More remarkable is the relatively high percentage of unskilled women in Belgium; $33.9 \%$.

On average $45 \%$ of all women employed in this occupational sector are lower skilled. Denmark and the United Kingdom in particular show high proportions of lower skilled women. The percentage for Denmark is especially remarkable, as in general many women in this country are intermediate skilled.

In the European Union approximately 1 out of 4 women working in this occupational sector are intermediate skilled. Again we see that the Federal Republic of Germany, Denmark and the Netherlands show high employment shares of intermediate skilled women whereas Spain and Portugal show very low proportions of intermediate skilled women in this occupational sector. 
$-75-$

Table 4.14. Skill levels of female service workers $(5)$ in 1991

\begin{tabular}{|c|c|c|c|c|}
\hline country & $\begin{array}{l}\text { unskilled } \\
\%\end{array}$ & $\begin{array}{l}\text { lower } \\
\text { skilled } \\
\%\end{array}$ & $\begin{array}{l}\text { intermediate } \\
\text { skilled } \\
\quad \%\end{array}$ & $\begin{array}{l}\text { highly } \\
\text { skilled } \\
\%\end{array}$ \\
\hline Belgium & 33.9 & 38.4 & 24.5 & 3.2 \\
\hline Federal Republic of Germany & 4.5 & 32.1 & 49.9 & 4.0 \\
\hline Denmark & - & 54.5 & 38.2 & 2.6 \\
\hline Greece & 59.4 & 9.9 & 17.5 & 4.5 \\
\hline Spain & 65.3 & 23.7 & 9.7 & 1.3 \\
\hline \multicolumn{5}{|l|}{ France } \\
\hline Ireland & 29.4 & 31.8 & 29.6 & 8.7 \\
\hline Luxembourg & 74.8 & 21.4 & - & - \\
\hline Netherlands & 19.9 & 37.6 & 39.2 & 3.2 \\
\hline Portugal & 90.9 & 6.6 & 2.0 & - \\
\hline United Kingdom & 0.2 & 75.5 & 13.2 & 3.7 \\
\hline European Union & 20.5 & 45.1 & 25.7 & 3.2 \\
\hline
\end{tabular}

Source: EUROSTAT/ROA

On average only $3.2 \%$ of all female sales workers are highly skilled. A positive exception is in Ireland, where highly skilled women have an employment share of $8.7 \%$ in this occupational sector.

Compared to the total working population in this occupational sector (see table 2.6), the average skill level of women is again less than the total skill level.

The female 'agricultural, animal husbandry and forestry workers, fishermen and hunters' (see table 4.15) are characterised by a high percentage of unskilled workers. The modal woman in this occupational sector is unskilled. Three countries show employment shares of unskilled women of over $75 \%$. In Portugal some $99 \%$ of all women employed in this occupational sector are unskilled. Belgium and Ireland also show high percentages of unskilled women.

Looking at the lower skilled women we again see Belgium with a high proportion, at $39.5 \%$, where the average is $20.2 \%$. The Federal Republic of Germany, Denmark, the Netherlands and the United Kingdom also show high employment shares of lower skilled women. In the light of the preceding tables it is no surprise to find that three quarters of the British women employed in this occupational sector are lower skilled.

Intermediate skilled women have an average employment share of $14.4 \%$ across the Union. The Federal Republic of Germany, Denmark, Ireland and the Netherlands again show relatively large employment shares of intermediate skilled women, whereas Greece, Spain and Portugal again show relatively small shares. 
Table 4.15. Skill levels of female agricultural, animal husbandry and forestry workers, fishermen and hunters (6) in 1991

\begin{tabular}{|c|c|c|c|c|}
\hline country & $\begin{array}{l}\text { unskilled } \\
\%\end{array}$ & $\begin{array}{l}\text { lower } \\
\text { skilled } \\
\%\end{array}$ & $\begin{array}{l}\text { intermediate } \\
\text { skilled } \\
\%\end{array}$ & $\begin{array}{l}\text { highly } \\
\text { skilled } \\
\%\end{array}$ \\
\hline Belgium & 39.2 & 39.5 & 15.5 & - \\
\hline Federal Republic of Germany & 1.6 & 41.1 & 43.0 & 5.1 \\
\hline Denmark & - & 59.6 & 34.0 & - \\
\hline Greece & 76.9 & 2.9 & 3.1 & - \\
\hline Spain & 86.8 & 11.5 & 1.4 & - \\
\hline \multicolumn{5}{|l|}{ France } \\
\hline Ireland & 39.7 & 24.8 & 25.6 & - \\
\hline Luxembourg & 58.8 & 35.3 & - & - \\
\hline Netherlands & 13.9 & 49.2 & 34.5 & - \\
\hline Portugal & 99.0 & 0.7 & & - \\
\hline United Kingdom & - & 75.4 & 14.0 & - \\
\hline European Union & 57.8 & 20.2 & 14.4 & 1.3 \\
\hline
\end{tabular}

Source: EUROSTAT/ROA

This occupational sector shows the smallest employment share of highly skilled women, at just 1.3\%. Except for the Federal Republic of Germany, with $5.1 \%$, no country reached its threshold value.

Compared to the total workforce (see table 2.7) women in this sector again show an average skill level that is less than the total average skill level. At all skill levels except for the unskilled, women's shares lie far below the total averages.

Finally to table 4.16, which gives the skill levels of female 'production and related workers'. As we could see in figure 4.8 , only $15 \%$ of the employment in this occupational sector is held by women. In Greece, Spain and Portugal, and less markedly in Belgium, unskilled women have a relatively high employment share in this sector.

On average $46.2 \%$ of the women employed in this occupational sector are lower skilled. The United Kingdom and Denmark have relatively large employment shares for lower skilled women, whereas in Portugal and Greece employment shares for lower skilled women in this sector are very small.

As in the preceding table, the Federal Republic of Germany, Denmark, Ireland and the Netherlands have relatively high proportions of intermediate skilled women in this occupational sector, whereas Spain, Portugal and the United Kingdom have only relatively small proportions.

$1.7 \%$ of all women employed in this occupational sector are highly skilled. The countries listed in the table do not show large differences in this respect. Again, the average skill level of women is less than the total average skill level (see table 2.8). 
Table 4.16. Skill levels of female production and related workers, transport equipment operators and labourers $(7 / 8 / 9)$ in 1991

\begin{tabular}{lcccc}
\hline unskilled & $\begin{array}{c}\text { lower } \\
\text { skilled } \\
\%\end{array}$ & $\begin{array}{c}\text { intermediate } \\
\text { skilled } \\
\%\end{array}$ & $\begin{array}{c}\text { highly } \\
\text { skilled } \\
\%\end{array}$ \\
\hline Belgium & $\%$ & 42.8 & 19.8 & 1.8 \\
Federal Republic of Germany & 33.3 & 38.6 & 45.1 & 2.5 \\
Denmark & 5.7 & 53.4 & 36.7 & 2.7 \\
Greece & - & 11.1 & 18.9 & 1.6 \\
Spain & 59.7 & 37.0 & 8.7 & 0.5 \\
France & 53.3 & 41.4 & 27.8 & - \\
Ireland & & - & - & - \\
Luxembourg & 20.1 & 43.7 & 30.4 & - \\
Netherlands & 80.0 & 4.4 & 0.7 & - \\
Portugal & 22.8 & 82.9 & 8.7 & 2.0 \\
United Kingdom & 93.7 & 46.2 & 23.3 & 1.7 \\
European Union & - & & & \\
\hline
\end{tabular}

Source: EUROSTAT/ROA

Changes in women's skill levels

In order to give an indication of the shifts in the skill structure of female employment we will now focus on the percentage points changes in the employment shares of the various skill levels in the period 1988-1991, differentiated by occupational sector.

Table 4.17 shows the shifts in employment shares of unskilled female workers. ${ }^{19}$ On average the employment share of unskilled workers decreased by 1.5 percentage points in this period. Greece, Spain and Portugal show the largest decreases in the employment shares of unskilled female workers. In these three countries the employment shares of unskilled women decreased by $6.1,8.4$ and 7.4 percentage points respectively. The size of these shifts is quite remarkable for such a relatively short period, although some decrease was expected as these countries showed employment shares of unskilled female workers that were much higher than in the other Member States (see table 4.9). Remarkably only the Federal Republic of Germany shows an increase in the employment share of unskilled female workers. Looking at the changes in the employment shares of unskilled female workers in the various occupational sectors, some opposing tendencies can be seen. In the occupational sectors of 'professional, technical and related workers', 'administrative and managerial workers', and 'clerical and related workers' the employment shares of unskilled women increased, whereas in the other occupational sectors the employment shares of unskilled women decreased.

19. There was again no data available for the Netherlands for 1988 so that, in addition to France, the Netherlands is excluded from this analysis. 
Table 4.17. Change, in percentage points, in the employment shares of unskilled female workers by occupational sector in the period 1988-1991

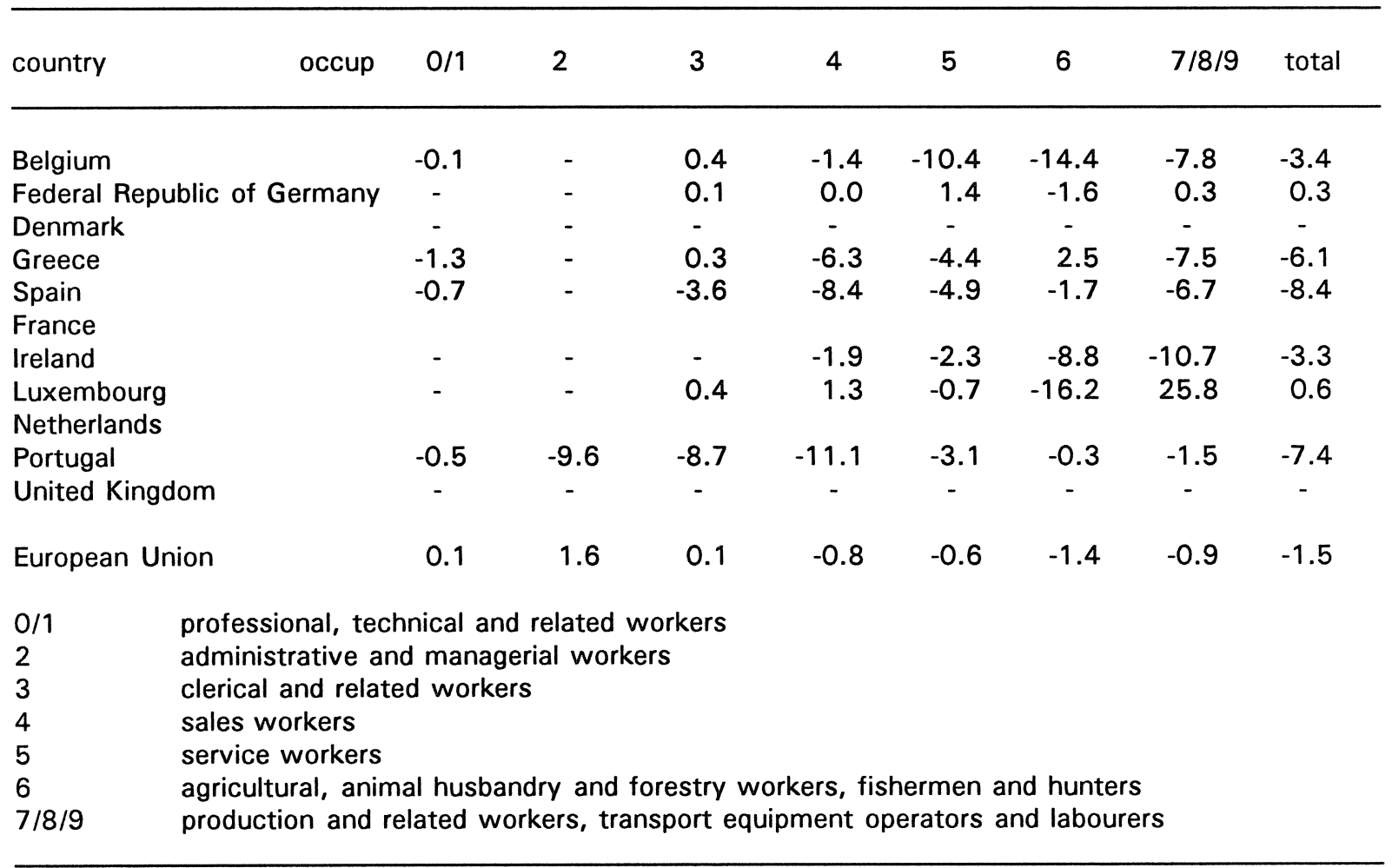

Source: EUROSTAT/ROA

Table 4.18 shows that the average total employment share of lower skilled female workers across the European Union decrease by 8.1 percentage points in the period 1988-1991. The Federal Republic of Germany shows an enormous decrease, by 16.3 percentage points, while in the other Member States the greatest decrease was 4.9 percentage points in Denmark. All occupational sectors show a decrease in the European average employment shares of lower skilled female workers, but contrary trends can be seen in some Member States. In Greece, Spain and Portugal the employment shares of lower skilled female workers generally increased, whereas in the other countries the employment shares of lower skilled female workers decreased. The occupational sector of female 'agricultural, animal husbandry and forestry workers, fishermen and hunters' is exceptional, in that it is only in the Federal Republic of Germany and Denmark that the employment share of lower skilled female workers decreased, and all other listed countries recorded increases. 
Table 4.18. Change, in percentage points, in the employment shares of lower skilled female workers by occupational sector in the period 1988-1991

\begin{tabular}{|c|c|c|c|c|c|c|c|c|c|}
\hline countr & occup & $0 / 1$ & 2 & 3 & 4 & 5 & 6 & $7 / 8 / 9$ & total \\
\hline \multicolumn{2}{|c|}{ Belgium } & -1.9 & -3.8 & -5.0 & -7.4 & 2.4 & 9.8 & 1.0 & -3.0 \\
\hline \multicolumn{2}{|c|}{ Federal Republic of Germany } & -9.1 & -9.1 & -17.4 & -18.7 & -17.1 & -20.9 & -15.7 & -16.3 \\
\hline \multicolumn{2}{|c|}{ Denmark } & -4.7 & 2.9 & 0.0 & -6.8 & -11.5 & -4.6 & -3.9 & -4.9 \\
\hline \multicolumn{2}{|c|}{ Greece } & -0.1 & - & 1.2 & -0.1 & 2.3 & 1.0 & 2.3 & 1.3 \\
\hline \multicolumn{2}{|c|}{ Spain } & -1.0 & - & -2.2 & 6.4 & 2.7 & 1.9 & 6.2 & 2.2 \\
\hline \multicolumn{10}{|c|}{ France } \\
\hline \multicolumn{2}{|c|}{ Ireland } & - & - & -0.9 & -4.0 & 0.7 & 2.5 & 3.4 & -0.3 \\
\hline \multicolumn{2}{|c|}{ Luxembourg } & 2.5 & - & 0.8 & -4.0 & \multicolumn{3}{|c|}{ Netherlands } & 1.4 \\
\hline \multicolumn{2}{|c|}{ Portugal } & 1.4 & - & 2.2 & 7.6 & 2.4 & - & 1.5 & 3.3 \\
\hline \multicolumn{2}{|c|}{ United Kingdom } & 2.1 & -1.2 & -3.1 & -2.1 & -3.4 & 7.0 & -3.0 & -3.2 \\
\hline \multicolumn{2}{|c|}{ European Union } & -4.1 & -5.2 & -11.0 & -8.3 & -8.0 & -3.4 & -6.9 & -8.1 \\
\hline $0 / 1$ & \multicolumn{9}{|c|}{ professional, technical and related workers } \\
\hline 2 & \multicolumn{9}{|c|}{ administrative and managerial workers } \\
\hline 3 & \multicolumn{9}{|c|}{ clerical and related workers } \\
\hline 4 & \multicolumn{9}{|c|}{ sales workers } \\
\hline 5 & \multicolumn{9}{|l|}{ service workers } \\
\hline 6 & \multicolumn{9}{|c|}{ agricultural, animal husbandry and forestry workers, fishermen and hunters } \\
\hline $7 / 8 / 9$ & \multicolumn{9}{|c|}{ production and related workers, transport equipment operators and labourers } \\
\hline
\end{tabular}

Source: EUROSTAT/ROA

Table 4.19 is marked by an average increase in the employment share of intermediately skilled women, by 7.6 percentage points. In the Federal Republic of Germany the employment share of intermediate skilled women increased by 12.9 percentage points, and Greece also saw a substantial increase, of $\mathbf{5 . 6}$ percentage points. Remarkably, in Ireland the employment share of intermediate skilled women decreased by 1.1 percentage points. This is the only Member State which has seen a decrease in the employment share of intermediate skilled women. If we focus on the various occupational sectors, we can see that in general it is in the occupational sectors of 'clerical and related worker', 'service workers' and 'sales workers' that the employment shares of intermediately skilled women have increased most, by 9.2, 8.2 and 8.1 percentage points, respectively. Most striking in this table is the increase in the employment share of intermediate skilled women in the occupational sector of 'agricultural, animal husbandry and forestry workers, fishermen and hunters' in the Federal Republic of Germany. This is the largest increase seen in any country (18.7 percentage points), although this is the occupational sector that showed the largest decrease in employment (see figure 1.1). It is also remarkable that in Denmark and in Ireland the employment shares of intermediately skilled female 'clerical and related workers' decreased, whereas all other Member States showed a relatively high employment increase. One last feature worth noting is that the employment share of intermediately skilled female 'administrative and managerial workers' increased only in the Federal Republic of Germany and the United Kingdom. In all other countries the employment share of intermediately skilled women in this occupational sector decreased. 
Table 4.19. Change, in percentage points, in the employment shares of intermediate skilled female workers by occupational sector in the period 1988-1991

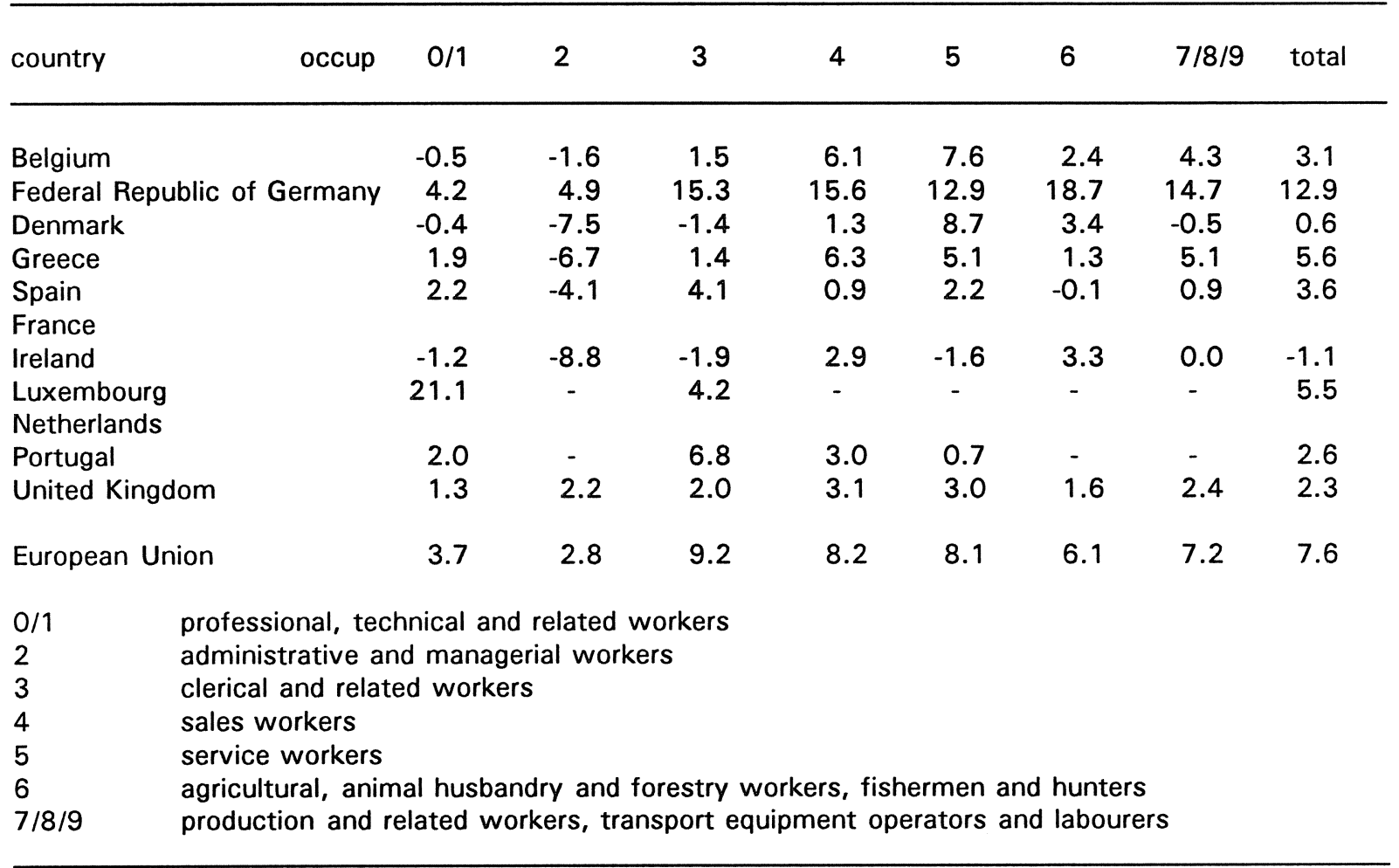

Source: EUROSTAT/ROA

Table 4.20 shows the shifts in the employment shares of highly skilled women in the various countries. The employment share of highly skilled women increased by an average of 2 percentage points. Belgium and Ireland showed relatively high increases, with 3.2 and 3.3 percentage points, respectively. It is remarkable that the employment share of highly skilled women increased in all countries. However, great differences can be seen between the occupational sectors. The occupational sector of 'administrative and managerial workers' showed the highest increase in the employment share of highly skilled women, by 3.1 percentage points. In three occupational sectors the employment shares of highly skilled women even decreased slightly. These sectors were the 'professional, technical and related workers', 'service workers' and female 'agricultural, animal husbandry and forestry workers, fishermen and hunters' with decreases of $0.2,0.1$ and 0.2 percentage points respectively. It is remarkable that the employment share of highly skilled female 'administrative and managerial workers' in Greece, Spain and Ireland decreased considerably, yet the increase in the employment share of highly skilled women in this occupational sector at European level is the highest of all occupational sectors. 
Table 4.20. Change, in percentage points, in the employment shares of highly skilled female workers by occupational sector in the period 1988-1991

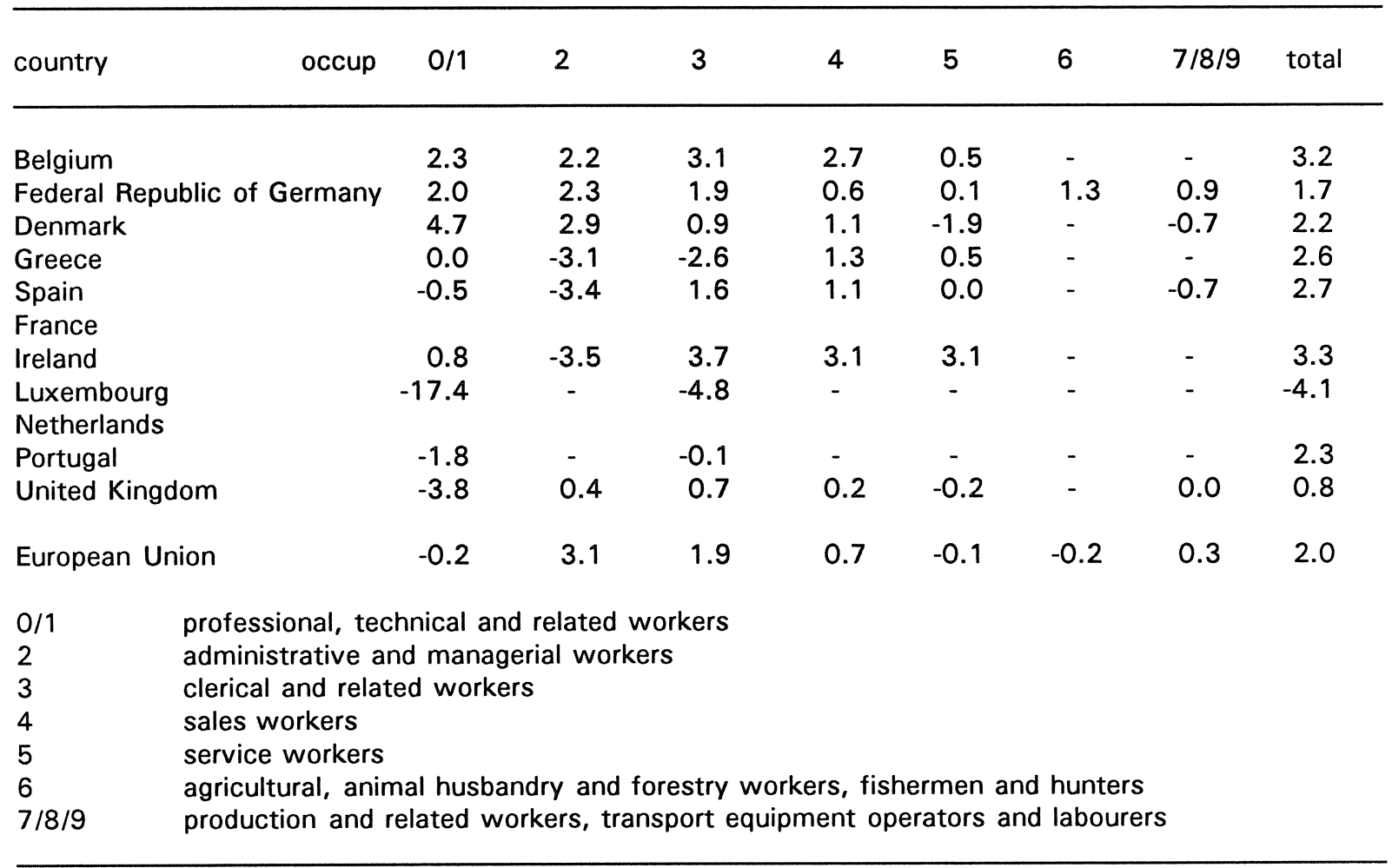

Source: EUROSTAT/ROA

\section{Women's participation in training}

Participation in training is the second factor, along with educational levels, which determines the skill level of women in the European Union. Table 4.21 shows that $9.1 \%$ of all female workers in the EU participated in training in 1991. However, the differences between the various Member States are quite substantial. Whereas Denmark, the Netherlands and the United Kingdom had female training participation rates of $18.2 \%, 20.1 \%$ and $15.5 \%$, respectively, Belgium, Greece, Spain, France and Portugal all show participation rates of less than $5 \%$. In Greece and Portugal women's participation in training is even below $2 \%$. This general picture confirms that, especially in Denmark, the Netherlands and the United Kingdom, training policies are also of great importance for female workers.

On average, participation in training by women increased by 0.9 percentage points in the period 1987-1991. The largest increases were in the Netherlands and the United Kingdom: 3.4 percentage points in both countries. On the other hand the Federal Republic of Germany, Greece and Ireland experienced decreases in the proportion of women participating in training of $1.4,0.3$ and 0.9 percentage points, respectively.

When we compare the percentage of women participating in training to the percentage of the total workforce who participate, we can see that on average there is hardly any difference. In 
five Member States women participate more in training than the total workforce, and in five other Member States they participate less. The most remarkable difference is in Portugal, where the percentage of women participating in training is much lower than the participation rate of the total workforce. Denmark, the Netherlands and the United Kingdom show low relative participation rates, while Ireland has a high percentage of women participating in training relative to the participation of the total working population in this country.

Table 4.21. Participation in training by female employment (total) in 1991 and \%-points change in the period 1987-1991

country

1991

$\%$ of female $\%$ of total

employed
1987-1991

$\%$-points change

female employed

$\begin{array}{lrrr}\text { Belgium } & 2.6 & 2.4 & 0.1 \\ \text { Federal Republic of Germany } & 8.9 & 9.0 & -1.4 \\ \text { Denmark } & 18.2 & 22.7 & 0.3 \\ \text { Greece } & 1.5 & 1.3 & -0.3 \\ \text { Spain } & 3.2 & 3.0 & 0.2 \\ \text { France } & 4.4 & 4.2 & 1.0 \\ \text { Ireland } & 8.0 & 7.2 & -0.9 \\ \text { Luxembourg } & 5.4 & 4.6 & 0.4 \\ \text { Netherlands } & 20.1 & 21.2 & 3.4 \\ \text { Portugal } & 1.7 & 3.6 & 0.5 \\ \text { United Kingdom } & 15.5 & 16.3 & 3.4 \\ & & & 0.9 \\ \text { European Union } & 9.1 & 9.2 & \end{array}$

Source: EUROSTAT/ROA

Table 4.22 shows the participation in training of female 'professional, technical and related workers'. We can see that participation in training in this occupational sector is much higher than the average participation rate shown in the preceding table. On average $15.3 \%$ of all women employed in this occupational sector participated in training. The United Kingdom shows the highest participation rate, $28.4 \%$, and Belgium shows the lowest rate with $2.8 \%$. Other countries with relatively high participation rates are Denmark and the Netherlands, while Greece, Spain, France and Portugal join Belgium in having low participation rates.

The participation in training of women in this occupational sector increased by 1.1 percentage points in the period 1987-1991. Ireland and the United Kingdom show the largest increases, of 3.8 and 4.3 percentage points respectively. The training participation rates of women decreased in the Federal Republic of Germany (1.1 percentage points), Spain (0.8 percentage points), and the Netherlands $(0.4$ percentage points). The decrease in the Netherlands is most striking, since women's participation rates in other occupational sectors increased.

When we compare the percentage of women participating in training to the participation rate of the total workforce, we can see that on average women in this occupational sector have higher 
participation rates than men. Especially in the Federal Republic of Germany and the Netherlands, participation rates are relatively high. Nevertheless, in Greece, Spain and Portugal participation rates for women are below the rates for the total workforce.

Table 4.22. Participation in training by female professional, technical and related workers (0/1) in 1991 and \%-points change in the period 1987-1991

\begin{tabular}{lccc}
\hline country & $\begin{array}{l}\text { 1991 } \\
\text { \% of female } \\
\text { employed }\end{array}$ & $\begin{array}{l}\text { 1991 } \\
\% \text { of total } \\
\text { employment }\end{array}$ & $\begin{array}{l}\text { 1987-1991 } \\
\text { \%-points change } \\
\text { female employed }\end{array}$ \\
\hline Belgium & 2.8 & 3.7 & 0.7 \\
Federal Republic of Germany & 12.2 & 10.5 & -1.1 \\
Denmark & 21.5 & 23.3 & 2.0 \\
Greece & 3.7 & 2.9 & 1.7 \\
Spain & 6.1 & 6.5 & -0.8 \\
France & 8.3 & 7.9 & 1.0 \\
Ireland & 11.3 & 12.9 & 3.8 \\
Luxembourg & 16.2 & 5.9 & 6.4 \\
Netherlands & 23.3 & 23.1 & -0.4 \\
Portugal & 5.7 & 8.2 & 2.0 \\
United Kingdom & 28.4 & 26.6 & 4.3 \\
European Union & 15.3 & 14.2 & 1.1 \\
\hline
\end{tabular}

Source: EUROSTAT/ROA

On average $11.9 \%$ of all female 'administrative and managerial workers' participate in training. Table 4.23 shows, however, that only in a few countries does the number of women who participate in training, reach the threshold value for publication of the data. The countries which did reach the threshold level are those which have already had high training participation rates for women in the preceding tables, plus Germany. It is not surprising to see that the training participation rates of women in Denmark, the Netherlands and the United Kingdom lie far above the average participation rates in the occupational sector, whereas that of the Federal Republic of Germany lies well below the sectors' average participation rate.

The table shows that in the European Union the percentage of women who participate in training in this occupational sector increased by 1.1 percentage points in the period 1987-1991. It is notable that in Denmark the training participation rate of women in this occupational sector decreased by 7 percentage points, whereas in the Netherlands participation increased by 5.5 percentage points.

Compared to the percentage of the total working force in this occupational sector who participates in training, women generally participate more in training. The Netherlands shows a percentage of female participation that is much higher, whereas Denmark shows a much lower rate for female participation in training than the rate for the total workforce in this occupational sector. 
Table 4.23. Participation in training by female administrative and managerial workers (2) in 1991 and \%points change in the period 1987-1991

\begin{tabular}{lccc}
\hline country & $\begin{array}{l}\text { 1991 } \\
\text { \% of female } \\
\text { employed }\end{array}$ & $\begin{array}{l}1991 \\
\% \text { of total } \\
\text { employment }\end{array}$ & $\begin{array}{l}\text { 1987-1991 } \\
\text { \%-points change } \\
\text { female employed }\end{array}$ \\
\hline Belgium & - & 1.9 & - \\
Federal Republic of Germany & 6.2 & 4.9 & -0.9 \\
Denmark & 15.7 & 17.4 & -7.0 \\
Greece & - & 2.2 & - \\
Spain & - & 1.9 & - \\
France & - & 2.4 & - \\
Ireland & - & 5.8 & 5.5 \\
Luxembourg & - & - & - \\
Netherlands & 20.5 & 13.9 & 1.3 \\
Portugal & - & 1.3 & 1.2 \\
United Kingdom & 15.9 & 14.8 & - \\
European Union & 11.9 & 9.4 & \\
\hline
\end{tabular}

Source: EUROSTAT/ROA

The participation in training of female 'clerical and related workers' in the European Union, as shown in table 4.24, also lies above the average level given in table 4.21 . On average $9.6 \%$ of the women employed in this occupational sector participate in training. Again we can see the high participation rates in Denmark, the Netherlands and the United Kingdom, and low participation in Belgium, Greece, Spain, France and Portugal.

The percentage of women who participate in training in this occupational sector increased by 1 percentage point in the period 1987-1991. The largest increases were in the Netherlands and the United Kingdom, with 3.7 and 3.5 percentage points, respectively. In Ireland the percentage of women participating in training also shows a large increase (2.4 percentage points). In Belgium, the Federal Republic of Germany, Denmark and Greece the percentages of women who participate in training show decreases of $1.3,1.1,1.4$ and 1.5 percentage points respectively.

The table also shows that women participate relatively less in training than the total workforce in this occupational sector. This tendency can be seen in most Member States. It is only in Greece that the percentage of women who participate in training is higher than the percentage of the total workforce that participates. Denmark, the Netherlands and Portugal show the largest negative gaps. 
Table 4.24. Participation in training by female clerical and related workers (3) in 1991 and \%-points change in the period 1987-1991

\begin{tabular}{lccc}
\hline country & $\begin{array}{l}1991 \\
\text { \% of female } \\
\text { employed }\end{array}$ & $\begin{array}{l}\text { 1991 } \\
\text { \% of total } \\
\text { employment }\end{array}$ & $\begin{array}{l}\text { 1987-1991 } \\
\text { \%-points change } \\
\text { female employed }\end{array}$ \\
\hline Belgium & 1.8 & 2.4 & -1.3 \\
Federal Republic of Germany & 8.4 & 9.1 & -1.1 \\
Denmark & 22.1 & 25.1 & -1.4 \\
Greece & 3.2 & 2.8 & 0.7 \\
Spain & 5.8 & 6.9 & -1.5 \\
France & 4.1 & 4.3 & 1.6 \\
Ireland & 7.3 & 8.6 & 2.4 \\
Luxembourg & 4.9 & 5.7 & 1.4 \\
Netherlands & 22.9 & 25.5 & 3.7 \\
Portugal & 3.9 & 7.5 & 1.1 \\
United Kingdom & 15.1 & 17.2 & 3.5 \\
European Union & 9.6 & 10.5 & 1.0 \\
\hline
\end{tabular}

Source: EUROSTAT/ROA

Table 4.25 presents the rates of participation in training of female 'sales workers'. The average percentage of women participating in training in this occupational sector is $8.1 \%$, which is well below the average participation in training as described in table 4.21 . The most striking feature in this table is the relatively small proportion of women who participate in training in the United Kingdom. Although the participation in training of female workers is still higher than the average participation in training of the total workforce in this country, the difference is relatively small. Denmark and the Netherlands, again, show very high percentages of women participating in training in this occupational sector. It is very remarkable that in Greece and Portugal hardly any female sales workers participate in training.

This is also the only occupational sector that shows a slight decrease in the average proportion of women participating in training. This is due largely to a considerable decrease in the Federal Republic of Germany, by 3.4 percentage points. Belgium is the only other country with a decrease $(0.4$ percentage points). In all other Member States the percentages of women participating in training increased. In Denmark, the Netherlands and the United Kingdom the participation rates increased, by $3.6,5.9$ and 2.3 percentage points respectively.

The table shows that on average women's rate of participation in training is again smaller than the training participation rate of the total workforce in this occupational sector. Denmark, the Netherlands and the United Kingdom show the largest gaps. However France and Ireland have slightly higher participation rates for women than for the total workforce in this occupational sector. 
Table 4.25. Participation in training by female sales workers (4) in 1991 and \%-points change in the period 1987-1991

\begin{tabular}{lccc}
\hline country & $\begin{array}{l}\text { 1991 } \\
\text { \% of female } \\
\text { employed }\end{array}$ & $\begin{array}{l}\text { 1991 } \\
\text { \% of total } \\
\text { employment }\end{array}$ & $\begin{array}{l}\text { 1987-1991 } \\
\text { \%-points change } \\
\text { female employed }\end{array}$ \\
\hline Belgium & 2.2 & 2.4 & -0.4 \\
Federal Republic of Germany & 8.5 & 9.2 & -3.4 \\
Denmark & 20.8 & 31.9 & 3.6 \\
Greece & - & 1.1 & - \\
Spain & 1.8 & 2.0 & 0.6 \\
France & 3.5 & 2.8 & 0.2 \\
Ireland & 6.5 & 6.1 & - \\
Luxembourg & 5.3 & 5.0 & 5.9 \\
Netherlands & 21.8 & 24.0 & - \\
Portugal & - & 3.1 & 2.3 \\
United Kingdom & 12.8 & 17.9 & -0.1 \\
European Union & 8.1 & 9.8 & \\
\hline
\end{tabular}

Source: EUROSTAT/ROA

The average percentage of female 'service workers' who participate in training is $7.2 \%$ (see table 4.26). Again, Greece and Spain do not reach their respective threshold values. Other countries with a relatively very low percentage of women participating in training are Belgium, Spain and France. Denmark, the Netherlands, and the United Kingdom, which in other sectors have participation rates well above the European average, differ relatively little in this sector from the average figure.

Table 4.26. Participation in training of female service workers (5) in 1991 and \%-points change in the period 1987-1991

\begin{tabular}{lccc}
\hline country & $\begin{array}{l}\text { 1991 } \\
\text { \% of female } \\
\text { employed }\end{array}$ & $\begin{array}{l}\text { 1991 } \\
\text { \% of total } \\
\text { employment }\end{array}$ & $\begin{array}{l}\text { 1987-1991 } \\
\text { \%-points change } \\
\text { female employed }\end{array}$ \\
\hline Belgium & 1.3 & 1.7 & -0.4 \\
Federal Republic of Germany & 9.4 & 9.2 & -2.8 \\
Denmark & 12.2 & 16.8 & 0.5 \\
Greece & - & 1.1 & - \\
Spain & 1.9 & 2.9 & 0.6 \\
France & 3.9 & 4.2 & 0.8 \\
Ireland & 6.0 & 7.8 & -1.1 \\
Luxembourg & 2.5 & 3.7 & 4.4 \\
Netherlands & 15.6 & 22.6 & - \\
Portugal & - & 3.1 & 2.6 \\
United Kingdom & 10.6 & 14.1 & 0.6 \\
European Union & 7.2 & 8.8 & \\
\hline
\end{tabular}


The total percentage of women participating in training in this occupational sector increased by 0.6 percentage points in the period 1987-1991. Again, the largest increases were in the Netherlands and the United Kingdom, with 4.4 and 2.6 percentage points respectively. Belgium and the Federal Republic of Germany are again the only two countries that show a decrease in the female training participate rate, by 0.4 and 2.8 percentage points respectively.

Compared to the percentage of the total workforce in this occupational sector participating in training, we can see that the female participation rate is again lower. Denmark, the Netherlands and the United Kingdom show the largest gaps. The Federal Republic of Germany is the only country in which female participation in training is higher than the participation rate of the total workforce in this occupational sector in this country.

As table 4.27 illustrates, female 'agricultural, animal husbandry and forestry workers, fishermen and hunters' show the lowest participation in training. On average only $2.2 \%$ of all female workers in this occupational sector participate in training. The most striking feature in this table is the very high percentage $(24.1 \%)$ of Danish women who participate in training in this occupational sector, whereas in the Netherlands, second in rank, only $9.4 \%$ of all women participate in training. This table also shows that the Federal Republic of Germany has a relatively high percentage of women participating in training in this occupational sector. In Belgium, Greece and Ireland the rates do not reach their respective threshold values.

Table 4.27. Participation in training by female agricultural, animal husbandry and forestry workers, fishermen and hunters (6) in 1991 and \%-points change in the period 1987-1991

\begin{tabular}{lccc}
\hline country & $\begin{array}{l}\text { 1991 } \\
\text { \% of female } \\
\text { employed }\end{array}$ & $\begin{array}{l}1991 \\
\% \text { of total } \\
\text { employment }\end{array}$ & $\begin{array}{l}\text { 1987-1991 } \\
\text { \%-points change } \\
\text { female employed }\end{array}$ \\
\hline Belgium & - & 1.1 & - \\
Federal Republic of Germany & 5.2 & 6.3 & -0.2 \\
Denmark & 24.1 & 16.8 & -13.8 \\
Greece & - & 0.1 & - \\
Spain & 0.8 & 0.7 & 0.2 \\
France & 1.0 & 1.3 & - \\
Ireland & - & 2.1 & - \\
Luxembourg & - & 4.5 & 2.6 \\
Netherlands & 9.4 & 14.0 & - \\
Portugal & 0.7 & 1.0 & 0.9 \\
United Kingdom & 7.7 & 9.8 & 0.2 \\
European Union & & 3.3 & \\
\hline
\end{tabular}

Source: EUROSTAT/ROA

The average percentage of women that participate in training increased by 0.2 percentage points in the period 1987-1991. What is most remarkable is the decrease of 13.8 percentage points in the proportion of Danish female 'agricultural, animal husbandry and forestry workers, 
fishermen and hunters' who participate, although Denmark still has a percentage of women who participate in training which is far higher than in all other Member States. However, because of the relative small proportion of Danish women employed in this occupational sector, the difference may have been caused by statistical measurement. The Netherlands and the United Kingdom again showed the highest increases in the proportion of women participating in training in this occupational sector, of 2.6 and 0.9 percentage points respectively.

In general the training participation rate of women in this occupational sector is considerably lower than the participation of the total workforce in this sector, although the latter is also quite low. Especially in the Netherlands, the gap between women and the total workforce is very large. Denmark, however, shows a very large gap in favour of women.

Table 4.28 shows the participation in training of female 'production and related workers, transport equipment operators and labourers'. In the European Union an average of $4.3 \%$ of all women employed in this occupational sector participate in training. The Netherlands $(11.6 \%)$ and Ireland $(11.3 \%)$ have by far the highest proportions of women participating in training. In this occupational sector Denmark and the United Kingdom are only third and fifth in rank. Greece, Spain, France and Portugal show very low percentages of women who participate in training with $1.9 \%, 1.6 \%, 1.6 \%$ and $1.1 \%$, respectively.

Table 4.28. Participation in training by female production and related workers, transport equipment operators and labourers (7/8/9) in 1991 and \%-points change in the period 1987-1991

\begin{tabular}{|c|c|c|c|}
\hline country & $\begin{array}{l}1991 \\
\% \text { of female } \\
\text { employed }\end{array}$ & $\begin{array}{l}1991 \\
\% \text { of total } \\
\text { employment }\end{array}$ & $\begin{array}{l}1987-1991 \\
\% \text {-points change } \\
\text { female employed }\end{array}$ \\
\hline Belgium & 2.5 & 1.8 & 0.4 \\
\hline Federal Republic of Germany & 6.1 & 8.7 & -0.3 \\
\hline Denmark & 7.5 & 19.4 & -2.1 \\
\hline Greece & 1.9 & 0.9 & 0.4 \\
\hline Spain & 1.6 & 1.5 & 0.4 \\
\hline France & 1.6 & 3.1 & 0.2 \\
\hline Ireland & 11.3 & 6.0 & -0.6 \\
\hline Luxembourg & - & 3.6 & - \\
\hline Netherlands & 11.6 & 16.6 & 1.7 \\
\hline Portugal & 1.1 & 2.3 & -0.4 \\
\hline United Kingdom & 6.0 & 10.2 & 1.5 \\
\hline European Union & 4.3 & 6.7 & 0.2 \\
\hline
\end{tabular}

Source: EUROSTAT/ROA

In this occupational sector the average proportion of female workers participating in training increased by 0.2 percentage points in the period 1987-1991. The Netherlands and the United Kingdom showed the highest increases, of 1.7 and 1.5 percentage points respectively, whereas the Federal Republic of Germany, Denmark and Portugal showed decreases by 0.3, 2.1 and $0.4 \%$ respectively. 
In this occupational sector female participation is on average below the participation rate of the total workforce. The Netherlands, the United Kingdom and, especially, Denmark show large gaps between the female participation in training and that of the total workforce in this occupational field. Ireland shows a remarkably large gap in favour of women in this occupational sector.

\subsection{Female job-seeking and the stability of employment relationships}

\section{Job-seeking by women}

Table 4.29 shows that $4.9 \%$ of the total female workforce of the European Union are looking for another job. In the Netherlands as many as $12.2 \%$ of all female workers are looking for another job. Another country that shows a relatively high rate of female job-seeking activity is Denmark with $7.3 \%$. The Federal Republic of Germany, Greece and Spain show relatively small percentages of women looking for another job, with $2.3 \%, 2.6 \%$ and $2.5 \%$ respectively.

Table 4.29. Percentage of female workers (total) looking for another job in 1991 and \%-points change in the period 1987-1991

\begin{tabular}{lccc}
\hline country & $\begin{array}{l}1991 \\
\text { \% of female } \\
\text { employed }\end{array}$ & $\begin{array}{l}1991 \\
\% \text { of total } \\
\text { employment }\end{array}$ & $\begin{array}{l}\text { 1987-1991 } \\
\text { \%-points change } \\
\text { female employed }\end{array}$ \\
\hline Belgium & 3.6 & 2.2 & -1.2 \\
Federal Republic of Germany & 2.3 & 2.0 & -0.2 \\
Denmark & 7.3 & 6.1 & -1.4 \\
Greece & 2.6 & 2.2 & 0.3 \\
Spain & 2.5 & 1.7 & -3.2 \\
France & 5.7 & 4.6 & -1.5 \\
Ireland & 6.0 & 4.7 & -1.4 \\
Luxembourg & 1.8 & 0.3 & -1.9 \\
Netherlands & 12.2 & 9.9 & -0.6 \\
Portugal & 3.6 & 2.6 & 0.2 \\
United Kingdom & 6.8 & 6.7 & -0.8 \\
European Union & 4.9 & 4.1 & \\
\hline
\end{tabular}

Source: EUROSTAT/ROA

The proportion of female job-seekers decreased by 0.8 percentage points in the period 19871991. The largest decreases in the percentage of female job-seekers have occurred in Spain and the Netherlands, with 3.2 and 1.9 percentage points respectively. Greece and the United Kingdom, however, show increases in the proportion of the female workforce who are looking for another job of 0.3 and 0.2 percentage points respectively.

If we compare the percentage of female job-seekers with the total percentage of job-seekers, it appears that women look for another job more frequently than men. In all Members States the 
percentage of women looking for another job is higher than the percentage for the entire workforce. The Netherlands shows the largest difference between female workers and the total workforce, whereas the Federal Republic of Germany, Greece and the United Kingdom show only relatively small differences.

On average $5.1 \%$ of all female 'professional, technical and related workers' are looking for another job (see table 4.30). This is higher than the average rate of job-seeking among female workers as described in the previous table. The Netherlands again shows the highest proportion of female job-seekers (15\%), and the Federal Republic of Germany, Greece, Spain and Portugal show the least female job-seeking activity: with $2.9 \%, 2.5 \%, 1.9 \%$ and $2.3 \%$, respectively.

Table 4.30 also shows that the average proportion of female job-seekers in this occupational sector decreased by 1.1 percentage points in the period 1987-1991. Ireland shows the largest increase in the proportion of women looking for another job, with 4.4 percentage points. Other countries with large decreases in the proportion of female job-seekers are Spain (3.7 percentage points), France (2.5 percentage points) and the Netherlands (2.2 percentage points). Portugal and the United Kingdom experienced small increases in the proportions of women looking for another job, of 0.1 and 0.5 percentage points respectively.

Table 4.30. Percentage of female professional, technical and related workers (0/1) looking for another job in 1991 and \%-points change in the period 1987-1991

country

$\begin{array}{lll}1991 & 1991 & 1987-1991 \\ \% \text { of female } & \% \text { of total } & \text { \%-points change } \\ \text { employed } & \text { employment } & \text { female employed }\end{array}$

$\begin{array}{lccc}\text { Belgium } & 3.3 & 2.7 & -1.0 \\ \text { Federal Republic of Germany } & 2.9 & 2.6 & -0.5 \\ \text { Denmark } & 6.4 & 6.7 & -1.1 \\ \text { Greece } & 2.5 & 1.8 & -0.6 \\ \text { Spain } & 1.9 & 1.5 & -3.7 \\ \text { France } & 3.7 & 3.7 & -2.5 \\ \text { Ireland } & 3.7 & 1.8 & -4.4 \\ \text { Luxembourg } & - & - & - \\ \text { Netherlands } & 15.0 & 13.5 & -2.2 \\ \text { Portugal } & 2.3 & 1.3 & 0.1 \\ \text { United Kingdom } & 6.8 & 6.7 & 0.5 \\ & & & \\ \text { European Union } & 5.1 & 4.6 & -1.1\end{array}$

\section{Source: EUROSTAT/ROA}

The difference between the proportion of women looking for another job and the job-seeking activity of the total workforce in this occupational sector is smaller than the difference for all occupational sectors together (table 4.29). In Denmark the percentage of female job-seekers is even lower than for the total working population in this occupational sector, in contrast to all the other Member States. In Ireland and the Netherlands the differences between the 
percentages of female workers in this occupational sector who are seeking a job and the figure for the total workforce in this sector are relatively large.

Table 4.31 shows that $4.3 \%$ of all female 'administrative and managerial workers' in the Union are looking for another job. However, only three countries could be listed here, because the proportions of female job-seekers in the other Member States did not reach their respective threshold values. ${ }^{20}$

Table 4.31 also shows that the proportion of female job-seekers in this occupational field in the European Union was rather stable in the period 1987-1991. From the three countries listed we can see that this was not necessarily the case for every individual Member State, since the Netherlands and the Federal Republic of Germany show decreases of 4.4 and 0.2 percentage points, respectively, whereas the United Kingdom shows an increase of 0.7 percentage points.

When we compare the percentage of female workers seeking new jobs to the percentage of all workers in this occupational sector who were seeking jobs, we can see again that the percentage of female job-seekers is higher. In the Netherlands the difference is even quite large.

Table 4.31. Percentage of female administrative and managerial workers (2) looking for another job in 1991 and \%-points change in the period 1987-1991

\begin{tabular}{llcc}
\hline country & $\begin{array}{l}1991 \\
\% \text { of female } \\
\text { employed }\end{array}$ & $\begin{array}{l}1991 \\
\% \text { of total } \\
\text { employment }\end{array}$ & $\begin{array}{c}1987-1991 \\
\%-\text { points change } \\
\text { female employed }\end{array}$ \\
\hline Belgium & - & - & - \\
Federal Republic of Germany & 1.7 & 1.0 & -0.2 \\
Denmark & - & - & - \\
Greece & - & - & - \\
Spain & - & - & - \\
France & - & - & - \\
Ireland & - & - & - \\
Luxembourg & - & 5.1 & -4.4 \\
Netherlands & 9.5 & - & 0.7 \\
Portugal \\
United Kingdom & - & 5.1 & 0.0 \\
European Union & 5.5 & 2.7 & - \\
\hline
\end{tabular}

Source: EUROSTAT/ROA

Table 4.32 shows that $4.9 \%$ of all female 'clerical and related workers' are looking for another job. This average percentage is exactly the same as the total average presented in table 4.29.

20. As we saw in figure 4.3 and table 4.2 , only a very small number of workers is employed in this occupational sector, and the employment share of women in this occupational sector is relatively small. Therefore it is not surprising that in a number of countries the proportions of female jobseekers did not reach their threshold values. 
The Netherlands, the United Kingdom and Denmark show relatively high percentages of women looking for another job, whereas the Federal Republic of Germany, Greece, Spain and Portugal again have relatively low percentages.

On average the percentage of female job-seekers decreased by 0.6 percentage points in this occupational sector in the period 1987-1991. Again the Netherlands shows the largest decrease (3 percentage points) in female job-seeking activity. Other countries showing relatively large decreases in female job-seeking are Belgium and Denmark, with 1.7 and 1.5 percentage points, respectively. However Greece, Portugal and the United Kingdom show increasing percentages of female job-seekers in this occupational sector, with increases of $0.2,0.3$ and 0.6 percentage points, respectively.

The average difference between the percentage of female job-seekers and total job-seeking activity is relatively small for this occupational sector. In the United Kingdom less female workers than total workers in this sector are looking for a new job, whereas all other Member States show higher percentages of female job-seekers than for total job-seekers. Belgium and Portugal show the largest differences between female job-seekers and total job-seekers in this occupational sector.

Table 4.32. Percentage of female clerical and related workers (3) looking for another job in 1991 and \%points change in the period 1987-1991

\begin{tabular}{lccc}
\hline & $\begin{array}{c}1991 \\
\% \text { of female } \\
\text { employed }\end{array}$ & $\begin{array}{c}1991 \\
\% \text { of total } \\
\text { employment }\end{array}$ & $\begin{array}{c}1987-1991 \\
\text { \%-points change } \\
\text { female employed }\end{array}$ \\
\hline Belgium & 4.3 & 3.0 & -1.5 \\
Federal Republic of Germany & 2.1 & 2.0 & -0.2 \\
Denmark & 6.6 & 6.4 & -1.7 \\
Greece & 2.8 & 2.2 & 0.2 \\
Spain & 1.8 & 1.3 & -1.1 \\
France & 5.7 & 4.9 & -1.3 \\
Ireland & 5.7 & 5.3 & -0.7 \\
Luxembourg & - & - & - \\
Netherlands & 11.5 & 11.0 & -3.0 \\
Portugal & 3.2 & 2.7 & 0.3 \\
United Kingdom & 6.9 & 7.2 & 0.6 \\
European Union & 4.9 & 4.5 & -0.6 \\
\hline
\end{tabular}

\section{Source: EUROSTAT/ROA}

The percentages of female 'sales workers' looking for another job are given in table 4.33. The table shows that on average $4.5 \%$ of female workers are looking for another job. This is slightly below the total average for female job-seeking presented in table 4.29. Denmark has the highest proportion of female job-seekers in this occupational sector, with $11.4 \%$. This percentage is much higher than in table 4.29 , indicating that the job satisfaction of Danish 
women is relatively low in this occupational sector. The Netherlands shows the second highest proportion of women looking for another job. The table also indicates that female 'sales workers' in Belgium, the Federal Republic of Germany and Spain are probably most satisfied with the jobs they have, as in these countries only $2.5 \%, 2.1 \%$ and $1.5 \%$ of sales workers are looking for another job.

The average proportion of women looking for another job decreased by 1 percentage point in the period 1987-1991. Denmark, Spain, Ireland and the Netherlands show large decreases in female job-seeking, of 2.3, 2.4, 2.2 and 2.2 percentage points, respectively. Spain is the only country that shows an increase (of 1.1 percentage points) in the percentage of women looking for another job.

Across the Union as a whole, the percentage of female 'sales workers' seeking a new job is only slightly higher that the figure for male and female workers together. In the Federal Republic of Germany, Spain and the United Kingdom the percentages of female job-seekers even lay slightly below those of the total workforce. For Denmark we can see that the percentage of women looking for another job is much higher than the rate of job-seeking activity in the whole occupational sector.

Table 4.33. Percentage of female sales workers (4) looking for another job in 1991 and \%-points change in the period 1987-1991

$\begin{array}{llll} & 1991 & 1991 & 1987-1991 \\ \text { country } & \begin{array}{l}\text { \% of female } \\ \text { employed }\end{array} & \begin{array}{l}\text { \% of total } \\ \text { employment }\end{array} & \begin{array}{c}\text { \%-points change } \\ \text { female employed }\end{array}\end{array}$

$\begin{array}{lrrr}\text { Belgium } & 2.5 & 2.1 & -1.7 \\ \text { Federal Republic of Germany } & 2.1 & 2.2 & -0.4 \\ \text { Denmark } & 11.4 & 8.5 & -2.3 \\ \text { Greece } & 3.3 & 2.3 & 1.1 \\ \text { Spain } & 1.5 & 1.6 & -2.4 \\ \text { France } & 5.5 & 4.8 & -1.2 \\ \text { Ireland } & 6.5 & 5.6 & -2.2 \\ \text { Luxembourg } & - & - & - \\ \text { Netherlands } & 9.8 & 8.3 & -2.2 \\ \text { Portugal } & 3.3 & 2.5 & -0.4 \\ \text { United Kingdom } & 6.8 & 7.0 & -0.5 \\ & & & -1.0\end{array}$

Source: EUROSTAT/ROA

Table 4.34 gives the proportions of female 'service workers' looking for another job. The table shows that $6.2 \%$ of all women employed in this occupational sector are looking for another job. This is the highest rate of job-seeking activity of all occupational sectors. The Netherlands, Denmark and France show the highest percentages of female job-seekers, with $11.3 \%, 9.5 \%$ and $8 \%$, respectively. The Federal Republic of Germany again shows by far the lowest 
proportion of women looking for another job $(2.5 \%)$. Other countries with low rates of female job-seekers are Belgium (4.8\%), Greece $(4.3 \%)$ and Spain $(4.6 \%)$.

Table 4.34 also shows that female service workers have had the largest average decrease in job-seeking activity. The average percentage of female 'service workers' looking for new jobs decreased by 1.5 percentage points in the period 1987-1991. Spain, with 4.4 percentage points, had the largest decrease. Another country showing a relatively large decrease in the percentage of women looking for another job is France, with 2.5 percentage points. Greece again shows an increase in female job-seeking activity, by 0.6 percentage points.

Female 'service workers' also have a higher rate of job-seeking than the total job-seeking activity in this occupational sector. Again the United Kingdom is the only country in which the percentage of female job-seekers is lower than the rate for the whole workforce in the sector. In all other Member States the proportion of women looking for another job is larger than for all 'service workers'. In Greece, Spain and France the gap is particularly large.

Table 4.34. Percentage of female service workers (5) looking for another job in 1991 and \%-points change in the period 1987-1991

\begin{tabular}{|c|c|c|c|}
\hline country & $\begin{array}{l}1991 \\
\% \text { of female } \\
\text { employed }\end{array}$ & $\begin{array}{l}1991 \\
\% \text { of total } \\
\text { employment }\end{array}$ & $\begin{array}{l}1987-1991 \\
\% \text {-points change } \\
\text { female employed }\end{array}$ \\
\hline
\end{tabular}

\begin{tabular}{lccc} 
Belgium & 4.8 & 3.9 & -1.3 \\
Federal Republic of Germany & 2.5 & 2.5 & -0.2 \\
Denmark & 9.5 & 8.5 & -0.3 \\
Greece & 4.3 & 3.0 & 0.6 \\
Spain & 4.6 & 3.5 & -4.4 \\
France & 8.0 & 6.9 & -2.5 \\
Ireland & 7.1 & 7.1 & -1.9 \\
Luxembourg & - & - & - \\
Netherlands & 11.3 & 11.4 & -1.5 \\
Portugal & 5.4 & 4.4 & -1.7 \\
United Kingdom & 7.2 & 7.5 & -0.1 \\
European Union & & & -1.5 \\
\hline
\end{tabular}

Source: EUROSTAT/ROA

Table 4.35 shows that $2.4 \%$ of all female 'agricultural, animal husbandry and forestry workers, fishermen and hunters' in the European Union are looking for another job. This is by far the lowest percentage of all occupational sectors. Belgium, Denmark and Ireland did not even reach their respective threshold values. Of the countries listed the Netherlands, Portugal and the United Kingdom show relatively high proportions of female job-seekers, whereas the Federal Republic of Germany and Greece show very little job-seeking in this occupational sector. 
In the European Union the proportion of women looking for another job decreased by 0.4 percentage points in the period 1987-1991. Spain, the Netherlands and the United Kingdom experienced relatively large decreases in their proportions of female job-seekers, by 2.2, 1.2 and 1.2 percentage points respectively. In the Federal Republic of Germany and France the proportions of female workers who were seeking new jobs rose slightly, with increases of 0.3 and 0.1 percentage points, respectively.

This is the only occupational sector in which the percentage of women looking for another job is lower than the rate of job-seeking activity for the total working population. Only the Netherlands and Portugal show percentages of female job-seeking higher than the level for the total workforce in this occupational sector.

Table 4.35. Percentage of female agricultural, animal husbandry and forestry workers, fishermen and hunters (6) looking for another job in 1991 and \%-points change in the period 1987-1991

\begin{tabular}{|c|c|c|c|}
\hline country & $\begin{array}{l}1991 \\
\% \text { of female } \\
\text { employed }\end{array}$ & $\begin{array}{l}1991 \\
\% \text { of total } \\
\text { employment }\end{array}$ & $\begin{array}{l}1987-1991 \\
\% \text {-points change } \\
\text { female employed }\end{array}$ \\
\hline Belgium & - & - & - \\
\hline Federal Republic of Germany & 1.4 & 1.5 & 0.3 \\
\hline Denmark & - & 3.1 & - \\
\hline Greece & 1.3 & 2.1 & 0.0 \\
\hline Spain & 2.1 & 3.5 & -2.2 \\
\hline France & 2.3 & 2.5 & 0.1 \\
\hline Ireland & - & 6.0 & - \\
\hline Luxembourg & - & - & - \\
\hline Netherlands & 6.0 & 4.1 & -1.2 \\
\hline Portugal & 3.8 & 3.6 & -0.3 \\
\hline United Kingdom & 3.8 & 5.3 & -1.2 \\
\hline European Union & 2.4 & 3.0 & -0.4 \\
\hline
\end{tabular}

\section{Source: EUROSTAT/ROA}

Table 4.36 shows that $4.2 \%$ of all women employed in the occupational sector of 'production and related workers, transport equipment operators and labourers' are looking for another job. This is a little below the average level of female job-seeking, as given in table 4.29. The Netherlands has the highest percentage of female job-seekers $(13 \%)$ in this occupational sector. Other countries with relatively high rates of female job-seeking activity are France and the United Kingdom, both with $6.1 \%$.

The average percentage of women looking for another job decreased by 0.4 percentage points in this occupational sector. Only the Federal Republic of Germany, Spain and Portugal experienced decreases in the percentages of women looking for another job, of $0.2,3.8$ and 0.7 percentage points, respectively. In all other Member States listed, the percentages of female job-seeking increased. The Netherlands shows the largest increase, with 1.6 percentage points. 
Comparing the percentage of women and the percentage of the total workforce in this occupational field who are looking for another job shows that relatively more women are seeking a new job. Especially in the Netherlands the proportion of female job-seekers is much higher.

Table 4.36. Percentage of female production and related workers, transport equipment operators and labourers (7/8/9) looking for another job in 1991 and \%-points change in the period 1987 . 1991

\begin{tabular}{llll}
\hline & 1991 & 1991 & $1987-1991$ \\
country & $\%$ of female & $\%$ of total & $\%$-points change \\
& employed & employment & female employed
\end{tabular}

$\begin{array}{lccc}\text { Belgium } & - & 1.1 & - \\ \text { Federal Republic of Germany } & 2.1 & 1.7 & -0.2 \\ \text { Denmark } & 5.5 & 5.5 & 0.0 \\ \text { Greece } & 2.8 & 2.3 & 0.4 \\ \text { Spain } & 1.6 & 1.0 & -3.8 \\ \text { France } & 6.1 & 4.4 & 0.5 \\ \text { Ireland } & - & 4.5 & - \\ \text { Luxembourg } & - & 0.9 & - \\ \text { Netherlands } & 13.0 & 7.5 & 1.6 \\ \text { Portugal } & 3.0 & 1.9 & -0.7 \\ \text { United Kingdom } & 6.1 & 6.1 & 0.8 \\ & & & -0.4 \\ \text { European Union } & 4.2 & 3.4 & -4\end{array}$

Source: EUROSTAT/ROA

\section{Temporary contracts}

Table 4.37 shows that $10.6 \%$ of all women employed in the European Union have a temporary contract. Especially in Spain the percentage of women working on temporary contracts is very high. In this country $\mathbf{2 8 . 7 \%}$ of all women employed work on a temporary basis. Portugal also shows a high percentage of women with a temporary contract, whereas Belgium, Greece and the United Kingdom have relatively few women working on a temporary contract. In these three countries the percentages amount to $6.6 \%, 8 \%$ and $6.5 \%$ respectively.

On average the proportion of women with temporary contracts increased by 1.7 percentage points in the period 1987-1991. Spain experienced an increase of 16.2 percentage points. This is in accordance with the picture sketched in table 3.9. Another country with a relatively large increase in the proportion of women with a temporary contract is France: 3.9 percentage points. In five Member States the proportion of women with temporary contracts decreased. Especially the Federal Republic of Germany and the Netherlands show large decreases of respectively 2.2 and 2 percentage points. 
Compared to the total workforce, we can see that on average women more often have temporary contracts than men. Especially in Belgium, Spain, Ireland and the Netherlands, women are over-represented in temporary jobs. Only in Greece shows hardly any gender difference in this respect.

Table 4.37. Percentage of female employment (total) with a temporary contract in 1991 and \%-points change in the period 1987-1991

\begin{tabular}{llll}
\hline & 1991 & 1991 & $1987-1991$ \\
country & $\begin{array}{l}\text { \% of female } \\
\text { employed }\end{array}$ & $\begin{array}{l}\text { \% of total } \\
\text { employment }\end{array}$ & $\begin{array}{l}\text { \%-points change } \\
\text { female employed }\end{array}$ \\
\hline
\end{tabular}

$\begin{array}{lrrr}\text { Belgium } & 6.6 & 4.0 & -0.5 \\ \text { Federal Republic of Germany } & 8.9 & 8.1 & -2.2 \\ \text { Denmark } & 11.6 & 10.5 & 0.6 \\ \text { Greece } & 8.0 & 7.9 & 0.9 \\ \text { Spain } & 28.7 & 24.1 & 16.2 \\ \text { France } & 10.5 & 8.7 & 3.9 \\ \text { Ireland } & 9.4 & 5.3 & -0.2 \\ \text { Luxembourg } & 2.9 & 2.0 & 0.8 \\ \text { Netherlands } & 9.3 & 6.7 & -2.0 \\ \text { Portugal } & 13.1 & 11.9 & 1.4 \\ \text { United Kingdom } & 6.5 & 4.8 & -0.7 \\ & & & 1.7\end{array}$

Source: EUROSTAT/ROA

Table 4.38 shows that on average $11.7 \%$ of all female 'professional, technical and related workers' in the European Union work on a temporary basis. This is somewhat higher than the total female average given in the preceding table. Again Spain shows a very high percentage of women with temporary contracts $(22.5 \%)$, whereas Belgium, Greece and the United Kingdom have relatively low percentages with $8.5 \%, 8.8 \%$ and $8.6 \%$, respectively.

In this occupational sector the percentage of women with a temporary contract increased by 1 percentage point. However, the table shows some opposing trends again, as six Member States had an increase in the percentage of women with a temporary contract, while four others had a decrease. Spain again experienced the largest increase in the proportion of women with temporary contracts, by 11.4 percentage points. Other countries having relatively large increases are Denmark, France and Portugal. The Netherlands had the largest decrease in the percentage of women with temporary work, by 4.1 percentage points. The Federal Republic of Germany, Ireland and the United Kingdom also had relatively large decreases in the percentage of women in this occupational sector having temporary work.

If we compare the percentage of women with a temporary contract with the proportion of the total sector workforce working under such contracts, we can see that women work relatively often under temporary contracts. Especially, in Denmark, the Federal Republic of Germany, 
Spain and the Netherlands the gender difference on this point is rather great, whereas in Portugal the difference is very small.

Table 4.38. Percentage of female professional, technical and related workers (0/1) with a temporary contract in 1991 and \%-points change in the period 1987-1991

\begin{tabular}{lccc}
\hline & $\begin{array}{c}1991 \\
\text { \% of female } \\
\text { employed }\end{array}$ & $\begin{array}{c}1991 \\
\% \text { of total } \\
\text { employment }\end{array}$ & $\begin{array}{c}1987-1991 \\
\text { \%-points change } \\
\text { female employed }\end{array}$ \\
\hline Belgium & & & 0.0 \\
Federal Republic of Germany & 8.5 & 5.8 & -2.3 \\
Denmark & 12.2 & 9.1 & 2.2 \\
Greece & 12.5 & 11.6 & 0.1 \\
Spain & 8.8 & 7.4 & 11.4 \\
France & 22.5 & 18.7 & 4.8 \\
Ireland & 11.6 & 9.3 & -1.7 \\
Luxembourg & 13.7 & 6.7 & -4.1 \\
Netherlands & - & - & 2.9 \\
Portugal & 11.4 & 8.8 & -1.4 \\
United Kingdom & 10.9 & 10.4 & 1.0 \\
European Union & 8.6 & 6.2 & \\
\hline
\end{tabular}

Source: EUROSTAT/ROA

Table 4.39. Percentage of female administrative and managerial workers (2) with a temporary contract in 1991 and \%-points change in the period 1987-1991

\begin{tabular}{lccc}
\hline country & $\begin{array}{l}1991 \\
\% \text { of female } \\
\text { employed }\end{array}$ & $\begin{array}{c}1991 \\
\% \text { of total } \\
\text { employment }\end{array}$ & $\begin{array}{c}\text { 1987-1991 } \\
\text { \%-points change } \\
\text { female employed }\end{array}$ \\
\hline Belgium & - & - & - \\
Federal Republic of Germany & 5.5 & 3.8 & -0.6 \\
Denmark & - & - & - \\
Greece & - & - & - \\
Spain & - & 2.2 & - \\
France & - & - & - \\
Ireland & - & - & - \\
Luxembourg & - & - & - \\
Netherlands & - & - & -0.3 \\
Portugal \\
United Kingdom & - & 1.1 & -0.6 \\
European Union & 1.8 & 1.7 & - \\
\hline
\end{tabular}

Source: EUROSTAT/ROA

Table 4.39 shows the percentage of female 'administrative and managerial workers' with a temporary contract. In this table only two countries are listed, which makes it impossible to 
make comparisons between the various EU countries. The percentage of female workers with a temporary contract is low compared to the other occupational sectors. The table also shows that this is the only occupational sector in which the percentage of women with a temporary contract has decreased. However, in this occupational sector the percentage of women with a temporary contract is relatively high compared to the percentage of total employment in the sector with a temporary contract.

In table 4.40 the percentages of female 'clerical and related workers' with temporary contracts are shown. The table shows that on average $9.3 \%$ of all women employed in this occupational sector have a temporary contract. Spain's percentage is very high, at $31.2 \%$. Other countries with relatively high percentages of female workers with a temporary contract are Denmark, France and Portugal, with $10 \%, 10 \%$ and $14.5 \%$, respectively. Belgium, the Federal Republic of Germany, Greece and the United Kingdom have low percentages of women with temporary jobs.

Table 4.40 also shows us that the percentage of women with a temporary contract in this occupational sector increased by 1.4 percentage points in the years 1987-1991. Spain had an increase of 20 percentage points. France, Ireland and Portugal also show relatively large increases in the percentage of women with a temporary contract, by $3.1,3.4$ and 3.7 percentage points, respectively. Belgium, the Federal Republic of Germany, Denmark and the Netherlands all show a decrease in the percentage of women with a temporary job.

Table 4.40. Percentage of female clerical and related workers (3) with a temporary contract in 1991 and $\%$-points change in the period 1987-1991

\begin{tabular}{|c|c|c|c|}
\hline country & $\begin{array}{l}1991 \\
\% \text { of female } \\
\text { employed }\end{array}$ & $\begin{array}{l}1991 \\
\% \text { of total } \\
\text { employment }\end{array}$ & $\begin{array}{l}1987-1991 \\
\% \text {-points change } \\
\text { female employed }\end{array}$ \\
\hline Belgium & 7.4 & 5.1 & -0.9 \\
\hline Federal Republic of Germany & 7.3 & 7.0 & -2.4 \\
\hline Denmark & 10.0 & 9.6 & -1.9 \\
\hline Greece & 7.8 & 6.2 & 1.1 \\
\hline Spain & 31.2 & 22.6 & 20.0 \\
\hline France & 10.0 & 8.4 & 3.1 \\
\hline Ireland & 8.7 & 7.3 & 0.2 \\
\hline Luxembourg & 3.4 & 1.7 & 3.4 \\
\hline Netherlands & 9.4 & 7.4 & -1.6 \\
\hline Portugal & 14.5 & 11.8 & 3.7 \\
\hline United Kingdom & 5.2 & 5.5 & 0.0 \\
\hline European Union & 9.3 & 8.4 & 1.4 \\
\hline
\end{tabular}

\section{Source: EUROSTAT/ROA}

The difference between the percentage of women with temporary contracts in this occupational sector and the percentage of the total European workforce with temporary contracts in this 
occupational sector is small. However, in Spain, Portugal, Belgium and the Netherlands the difference is relatively great.

Table 4.41 shows the female 'sales workers' with a temporary contract. In the European Union $9.1 \%$ of all women employed in this occupational sector have a temporary contract. Again, Denmark, Spain and Portugal have high percentages of female workers with temporary jobs. Most remarkable, however, is that only $6.4 \%$ of the French women employed in this occupational sector have temporary contracts, when a much higher percentage would be expected for this country (see table 4.37). Belgium, Greece, the Netherlands and the United Kingdom are other countries showing a relatively low percentage of female 'sales workers' with temporary contracts.

On average the percentage of women with temporary jobs in this occupational sector increased by 1.1 percentage points in the period 1987-1991. This is a relatively small increase. Spain experienced an increase of 14.4 percentage points. However, the Federal Republic of Germany, the Netherlands and the United Kingdom all experienced falls in the proportion of women working on a temporary basis.

The difference between the prevalence of temporary contracts among women and among the total workforce in this occupational sector is on average rather large, as the average percentage of female workers with a temporary job is 2 percentage points higher than that for the total workforce in the sector. The most remarkable difference is in Ireland. Denmark, Greece, Spain and Portugal also show relatively large differences.

Table 4.41. Percentage of female sales workers (4) with a temporary contract in 1991 and \%-points change in the period 1987-1991

country

1991

$\%$ of female $\%$ of total employed employment

1987-1991

\%-points change female employed

Belgium
Federal Republic of Germany
Denmark
Greece
Spain
France
Ireland
Luxembourg
Netherlands
Portugal
United Kingdom
European Union

\section{5}

8.6

14.5

7.0

22.0

6.4

9.8

6.1

11.8

6.2

9.1

\section{2}

7.2

10.7

4.3

16.4

5.0

3.9

2.2

4.7

8.5

5.0

7.1
0.8

$-2.8$

0.9

2.0

14.4

1.4

0.8

$-2.6$

1.7

$-0.3$

1.1 
Table 4.42 shows that on average $13.3 \%$ of all female 'service workers' have temporary contracts. This means that in this occupational sector has the highest temporary contract rates for women of all sectors. All Member States show percentages of women with temporary contracts above $8 \%$. Spain shows the highest percentage with $32.8 \%$, but Denmark, Greece, France, Ireland and Portugal also show relatively high percentages of women with temporary jobs. This is again a strong indication that this occupational sector, in which a relatively large proportion of all women are employed, can to a great extent be described as a secondary labour market.

The service workers also show the largest increase in the percentage of women with a temporary contract. On average the percentage increased by 2.5 percentage points. Spain and France show particularly large increases in the percentage of women with a temporary job. On the other hand, six Member States experienced a decrease in the percentage of women with temporary contracts in this occupational sector. The Federal Republic of Germany and Denmark show the largest decreases, of 3.3 and 2.3 percentage points, respectively.

Comparing the percentage of women with a temporary contract to the percentage of the total workforce in this occupational sector, we can see that women more often have a temporary contract. Especially Belgium, Greece, Spain, Ireland and Portugal show rather large differences, whereas in the Netherlands there is only a very small difference.

Table 4.42. Percentage of female service workers (5) with a temporary contract in 1991 and \%-points change in the period 1987-1991

\begin{tabular}{lccc}
\hline & $\begin{array}{l}1991 \\
\% \text { of female } \\
\text { employed }\end{array}$ & $\begin{array}{l}1991 \\
\% \text { of total } \\
\text { employment }\end{array}$ & $\begin{array}{c}1987-1991 \\
\text { \%-points change } \\
\text { female employed }\end{array}$ \\
\hline Belgium & & & -0.6 \\
Federal Republic of Germany & 9.1 & 6.8 & -3.3 \\
Denmark & 10.2 & 9.0 & 2.7 \\
Greece & 14.0 & 12.5 & -2.3 \\
Spain & 17.0 & 11.4 & 17.6 \\
France & 32.8 & 28.1 & 5.4 \\
Ireland & 13.2 & 12.7 & -1.1 \\
Luxembourg & 13.8 & 10.2 & -0.9 \\
Netherlands & 5.7 & 4.1 & -0.7 \\
Portugal & 8.2 & 8.5 & 0.3 \\
United Kingdom & 18.2 & 15.9 & -0.6 \\
European Union & 8.1 & 7.5 & 2.5 \\
\hline
\end{tabular}

Source: EUROSTAT/ROA

Table 4.43 shows the percentages of female 'agricultural, animal husbandry, and forestry workers, fishermen and hunters' with a temporary contract. On average $6.4 \%$ of all women have temporary contracts. This is a relatively low percentage compared to table 4.37 . In three 
countries the proportion of women with a temporary contract in this occupational sector was below the country's threshold value. Again Spain shows the highest percentage of women with temporary contracts: $18.8 \%$. Other countries having relatively high percentages of women with temporary jobs are the Netherlands and the United Kingdom. Of the countries listed, France and Portugal show relatively low percentages of women with temporary contracts.

On average the proportion of women working on a temporary basis increased by 1.8 percentage points in this occupational sector in the period 1987-1991. The Federal Republic of Germany, Spain and France are the only countries with increases in the percentage of women with temporary contracts, by $0.4,11.2$ and 1.4 percentage points respectively. All the other countries listed show decreases. The decrease in the percentage of Dutch women with a temporary contract is especially remarkable. In this country the percentage of women working in this sector under a temporary contract decreased by 6.2 percentage points. The United Kingdom also shows a rather large decrease, of 2.6 percentage points.

Remarkably, this is the only occupational sector in which the percentage of women with a temporary contract in the European Union lies below the percentage for the total working population in this occupational field. It is only in the Netherlands and the United Kingdom that women have a greater rate of temporary contracts than for the workforce as a whole. Even in Spain the percentage of women with a temporary contract is lower than the percentage of total employment in this occupational sector.

Table 4.43. Percentage of female agricultural, animal husbandry and forestry workers, fishermen and hunters (6) with a temporary contract in 1991 and \%-points change in the period 1987-1991

\begin{tabular}{|c|c|c|c|}
\hline country & $\begin{array}{l}1991 \\
\% \text { of female } \\
\text { employed }\end{array}$ & $\begin{array}{l}1991 \\
\% \text { of total } \\
\text { employment }\end{array}$ & $\begin{array}{l}1987-1991 \\
\% \text {-points change } \\
\text { female employed }\end{array}$ \\
\hline Belgium & - & - & - \\
\hline Federal Republic of Germany & 5.1 & 5.4 & 0.4 \\
\hline Denmark & - & 5.2 & - \\
\hline Greece & 1.4 & 1.7 & -0.6 \\
\hline Spain & 18.8 & 20.0 & 11.2 \\
\hline France & 3.4 & 3.4 & 1.4 \\
\hline Ireland & - & - & - \\
\hline Luxembourg & - & - & - \\
\hline Netherlands & 7.6 & 4.1 & -6.2 \\
\hline Portugal & 4.1 & 5.1 & -0.4 \\
\hline United Kingdom & 9.8 & 4.6 & -2.6 \\
\hline European Union & 6.4 & 7.2 & 1.8 \\
\hline
\end{tabular}

Source: EUROSTAT/ROA

Finally, table 4.44 describes the percentage of female 'production and related workers, transport equipment operators and labourers' with a temporary contract. The table shows that 
on average $12.4 \%$ of all women employed in this occupational sector have temporary contracts. This percentage is much higher than the total average given in table 4.37. Spain and Portugal have the highest percentages of women with temporary contracts, at $39.6 \%$ and $17.7 \%$, respectively. The United Kingdom has a very low percentage of women with temporary jobs in this occupational sector.

The European average percentage of women working on a temporary basis increased by 2.4 percentage points in the period 1987-1991. This increase is the second highest of all occupational sectors. Again Spain and France show the highest increases 119.9 and 4.5 percentage points respectively), whereas in three of the Member States listed the percentage decreased.

This occupational sector exhibits a large difference between the percentage of women with a temporary job and the percentage of total employment under temporary contracts. In Denmark and the Netherlands the difference is very large. On the other hand, in the Federal Republic of Germany, Denmark and Greece the percentages of women with a temporary contract lie below those for the total working population in this occupational sector.

Table 4.44. Percentage of female production and related workers, transport equipment operators and labourers (7/8/9) with a temporary contract in 1991 and \%-points change in the period 19871991

\begin{tabular}{lccc}
\hline Country & $\begin{array}{l}1991 \\
\% \text { of female } \\
\text { employed }\end{array}$ & $\begin{array}{c}1991 \\
\% \text { of total } \\
\text { employment }\end{array}$ & $\begin{array}{c}\text { 1987-1991 } \\
\text { \%-points change } \\
\text { female employed }\end{array}$ \\
\hline Belgium & - & 2.4 & - \\
Federal Republic of Germany & 8.0 & 8.9 & -1.4 \\
Denmark & 10.9 & 11.6 & 0.6 \\
Greece & 12.7 & 13.8 & 2.9 \\
Spain & 39.6 & 29.4 & 19.9 \\
France & 11.1 & 8.9 & - \\
Ireland & - & 4.9 & - \\
Luxembourg & - & 2.5 & 1.2 \\
Netherlands & 13.9 & 5.9 & -0.2 \\
Portugal & 17.7 & 15.5 & -2.3 \\
United Kingdom & 5.2 & 2.6 & 2.4 \\
European Union & 12.4 & 10.6 & - \\
\hline
\end{tabular}

\section{Source: EUROSTAT/ROA}

\section{Part-time work}

Table 4.45 gives the percentages of women working part-time in the various Member States. The table shows that almost 1 out of 3 women employed in the European Union works parttime. In the Netherlands some $59.8 \%$ of the female workforce have part-time jobs, whereas in 
Greece only $6.5 \%$ of all female workers have part-time jobs. France, Ireland, Spain and Portugal are other countries with small proportions of part-time working women, at $23.4 \%, 17.7 \%$, $11 \%$, and $9.9 \%$ of the female working population respectively. Another country with a high percentage of female part-time workers is the United Kingdom. In this country $43.7 \%$ of all women employed have part-time jobs.

The proportion of female part-time workers in the European Union increased by 0.8 percentage points in the period 1987-1991. A remarkable feature is that opposing trends can be identified, as in six Member States the percentage of women working part-time increased, whereas in four countries this percentage decreased. Belgium, France, Ireland and the Netherlands show the largest increases in the percentage of female part-time workers, of 3.3, 4.9, 2.3 and 2.3 percentage points, respectively, whereas Denmark, Greece and Spain show the largest decreases: $4.9,3.5$ and 2.6 percentage points, respectively.

Comparing the percentages of women working part-time with the percentages of the total workforce working part-time, it is quite evident that it is almost only women who work parttime, as we saw that $41 \%$ of the total workforce in the European Union is female (see figure 4.1).

Table 4.45. Percentage of female employment (total) working part-time in 1991 and \%-points change in the period 1987-1991

\begin{tabular}{lccc}
\hline country & $\begin{array}{l}\text { 1991 } \\
\text { \% of female } \\
\text { employed }\end{array}$ & $\begin{array}{l}1991 \\
\text { \% of total } \\
\text { employment }\end{array}$ & $\begin{array}{l}\text { 1987-1991 } \\
\text { \%-points change } \\
\text { female employed }\end{array}$ \\
\hline Belgium & 27.4 & 11.7 & 3.3 \\
Federal Republic of Germany & 34.1 & 15.1 & 4.9 \\
Denmark & 37.4 & 22.6 & -4.9 \\
Greece & 6.5 & 3.4 & -3.5 \\
Spain & 11.0 & 4.5 & -2.6 \\
France & 23.4 & 11.9 & 0.5 \\
Ireland & 17.7 & 8.3 & 2.3 \\
Luxembourg & 18.2 & 7.5 & 1.2 \\
Netherlands & 59.8 & 32.4 & 2.3 \\
Portugal & 9.9 & 5.8 & 0.1 \\
United Kingdom & 43.7 & 22.3 & -0.5 \\
European Union & 31.3 & 15.0 & 0.8 \\
\hline
\end{tabular}

Source: EUROSTAT/ROA

Table 4.46 shows that $28.6 \%$ of all female 'professional, technical and related workers' have part-time jobs. Again the Netherlands shows, with $59.2 \%$, an extremely high percentage of women working part-time. Denmark and the United Kingdom also show high percentages of female part-time workers in this sector, of $37 \%$ and $34.8 \%$ respectively. Greece, Spain and Portugal have very low percentages of women working part-time in this occupational sector, as 
only $6.1 \%, 7.6 \%$ and $4.1 \%$, respectively, of the women employed in this occupational sector have a part-time job.

Table 4.46 also shows that on average the percentage of women with part-time jobs in this occupational sector increased by 1.3 percentage points in the period 1987-1991. Belgium, the Federal Republic of Germany, Ireland and the Netherlands show relatively large increases in the percentage of women working part-time $(4.1,5,5.1$ and 2.5 percentage points, respectively), whereas Greece experienced a large decrease: 3.9 percentage points.

Bearing in mind that on average more than $45 \%$ of the total workforce employed in this occupational sector are female, the difference between the percentage of female part-time workers and the percentage of the total working population working part-time indicates that part-time work in this occupational sector is almost always done by female workers.

Table 4.46. Percentage of female professional, technical and related workers $(0 / 1)$ working part-time in 1991 and \%-points change in the period 1987-1991

\begin{tabular}{llcc}
\hline country & $\begin{array}{l}1991 \\
\text { \% of female } \\
\text { employed }\end{array}$ & $\begin{array}{l}\text { 1991 } \\
\text { \% of total } \\
\text { employment }\end{array}$ & $\begin{array}{l}\text { 1987-1991 } \\
\text { \%-points change } \\
\text { female employed }\end{array}$ \\
\hline Belgium & 27.6 & 14.9 & 4.1 \\
Federal Republic of Germany & 32.0 & 16.0 & 5.0 \\
Denmark & 37.0 & 26.9 & -1.2 \\
Greece & 6.1 & 3.9 & -3.9 \\
Spain & 7.6 & 5.7 & -1.3 \\
France & 18.8 & 10.5 & 0.1 \\
Ireland & 15.0 & 8.2 & 3.0 \\
Luxembourg & 17.8 & 6.6 & 5.1 \\
Netherlands & 59.2 & 36.5 & 2.5 \\
Portugal & 4.1 & 4.3 & 0.7 \\
United Kingdom & 34.8 & 18.8 & -0.4 \\
European Union & & 16.0 & 1.3 \\
\hline
\end{tabular}

Source: EUROSTAT/ROA

Table 4.47 shows that $17.3 \%$ of all female 'administrative and managerial workers' in the European Union have part-time jobs. Compared to the average percentage (see table 4.45) this is a very small proportion. Only the Netherlands shows a high percentage of women working part-time in this occupational sector, whereas Greece, Spain, France and especially Portugal have very low percentages. In Ireland the proportion of women working part-time in this occupational field did not even reach the threshold value.

The average percentage of women working part-time in this occupational sector increased by 1.9 percentage points in the period 1987-1991. This is the highest increase of all occupational sectors. Belgium, the Federal Republic of Germany and Spain had increases of 5.8, 6.9, 8.8 and 
5.4 percentage points respectively. On the other hand, Greece, France, the Netherlands and Portugal experienced decreases of $1.8,5.4,6.8$ and 3.3 percentage points, respectively.

Figure 4.3 showed that $24.6 \%$ of the total workforce employed in this occupational sector are female. Again this means that almost all part-time work in this occupational sector is done by women.

Table 4.47. Percentage of female administrative and managerial workers (2) working part-time in 1991 and \%-points change in the period 1987-1991

\begin{tabular}{lccc}
\hline country & $\begin{array}{l}1991 \\
\% \text { of female } \\
\text { employed }\end{array}$ & $\begin{array}{l}1991 \\
\% \text { of total } \\
\text { employment }\end{array}$ & $\begin{array}{c}1987-1991 \\
\text { \%-points change } \\
\text { female employed }\end{array}$ \\
\hline Belgium & 14.6 & 4.0 & 5.8 \\
Federal Republic of Germany & 17.1 & 4.4 & 6.9 \\
Denmark & 12.9 & 4.8 & 8.8 \\
Greece & 3.8 & 0.7 & -1.8 \\
Spain & 8.9 & 0.8 & 5.4 \\
France & 6.0 & 1.3 & -5.4 \\
Ireland & - & - & - \\
Luxembourg & - & 11.9 & -6.8 \\
Netherlands & 34.8 & 1.1 & -3.3 \\
Portugal & 1.7 & 7.2 & 0.0 \\
United Kingdom & 17.7 & 5.6 & 1.9 \\
European Union & 17.3 & & - \\
\hline
\end{tabular}

Source: EUROSTAT/ROA

From table 4.48 we can see that $28 \%$ of all female 'clerical and related workers' have part-time jobs. What is most remarkable in this occupational sector is the very low percentages of women working part-time in Greece, Spain and Portugal $(4.2 \%, 4.4 \%$ and $2.2 \%$, respectively). Again, the Netherlands has a very high proportion of women working part-time. Other countries with relatively high percentages of female part-time workers are the Federal republic of Germany and the United Kingdom.

In the European Union the percentage of women working part-time in this occupational sector increased by 1.5 percentage points in the period 1987-1991. The Federal Republic of Germany and the Netherlands show the highest increases (both 3.9 percentage points). Only Denmark, Greece and Spain experienced decreases in the percentages working part-time, by $5,5.4$ and 1.8 percentage points respectively.

Figure 4.4 showed that $64.1 \%$ of the total workforce employed in the occupational sector of 'clerical and related workers' are female. This means again that almost all part-time jobs in this occupational sector must be occupied by women. 
Table 4.48. Percentage of female clerical and related workers (3) working part-time in 1991 and \%-points change in the period 1987-1991

\begin{tabular}{llcc}
\hline country & $\begin{array}{l}\text { 1991 } \\
\text { \% of female } \\
\text { employed }\end{array}$ & $\begin{array}{l}\text { 1991 } \\
\text { \% of total } \\
\text { employment }\end{array}$ & $\begin{array}{l}\text { 1987-1991 } \\
\text { \%-points change } \\
\text { female employed }\end{array}$ \\
\hline Belgium & 24.0 & 13.7 & 1.4 \\
Federal Republic of Germany & 33.5 & 22.1 & 3.9 \\
Denmark & 30.9 & 24.6 & -5.0 \\
Greece & 4.2 & 2.6 & -5.4 \\
Spain & 4.4 & 2.7 & -1.8 \\
France & 20.8 & 15.1 & 2.1 \\
Ireland & 11.4 & 8.6 & 2.1 \\
Luxembourg & 11.9 & 7.0 & 3.8 \\
Netherlands & 48.7 & 33.0 & 3.9 \\
Portugal & 2.2 & 1.7 & 0.0 \\
United Kingdom & 35.1 & 27.3 & 1.6 \\
European Union & 28.0 & 19.3 & 1.5 \\
\hline
\end{tabular}

Source: EUROSTAT/ROA

Table 4.49 shows that on average $35.6 \%$ of all female 'sales workers' in the European Union have part-time jobs. It is striking that the percentage of women working part-time in the United Kingdom is almost as high as the percentage of in the Netherlands $(57.8 \%$ against $58.4 \%)$. Denmark also has a large percentage of the women employed in this occupational sector working part-time. Again Greece, Spain and Portugal show the smallest proportions of women working part-time.

Table 4.49. Percentage of female sales workers (4) working part-time in 1991 and \%-points change in the period 1987-1991

\begin{tabular}{lllr}
\hline country & $\begin{array}{l}1991 \\
\text { \% of female } \\
\text { employed }\end{array}$ & $\begin{array}{l}1991 \\
\% \text { of total } \\
\text { employment }\end{array}$ & $\begin{array}{l}\text { 1987-1991 } \\
\text { \%-points change } \\
\text { female employed }\end{array}$ \\
\hline Belgium & & & \\
Federal Republic of Germany & 25.8 & 13.1 & 3.2 \\
Denmark & 39.0 & 23.7 & 6.5 \\
Greece & 45.1 & 26.7 & -12.5 \\
Spain & 5.8 & 3.1 & -3.8 \\
France & 8.1 & 4.3 & -1.7 \\
Ireland & 23.5 & 12.7 & -0.2 \\
Luxembourg & 23.3 & 11.7 & 4.0 \\
Netherlands & 11.1 & 5.9 & -1.0 \\
Portugal & 58.4 & 41.6 & 1.4 \\
United Kingdom & 6.8 & 4.6 & -2.8 \\
European Union & 57.8 & 34.2 & 0.8 \\
& 35.6 & 20.9 & 0.6 \\
\hline
\end{tabular}


Table 4.49 also shows that in the European Union the percentage of women with part-time jobs in this occupational sector increased by 0.6 percentage points in the period 1987-1991. Five Member States had decreases, and five others show increases. The most striking changes are the decrease in the percentage of Danish female sales workers who work part-time by 12.5 percentage points, and the increase for the same group in Germany of 6.5 percentage points.

As figure 4.5 showed that approximately half of the total workforce in this occupational sector is female, we can see that only a small percentage of the male workers in this occupational sector work part-time.

Table 4.50 shows that $47.1 \%$ of all female 'service workers' in the European Union hold parttime jobs, the highest rate for any sector. In the Netherlands more than three quarters of all women employed in this occupational sector work part-time, and Denmark and the United Kingdom also show percentages of over $60 \%$. Greece, Spain and Portugal again show the smallest percentages of women working part-time in this occupational sector, but the difference between these three and the other Member States is relatively much smaller in this occupational sector. These very high percentages of part-time work again indicate that many women in this occupational field are working on the secondary segment of the labour market.

Table 4.50. Percentage of female service workers (5) working part-time in 1991 and \%-points change in the period 1987-1991

\begin{tabular}{llcc}
\hline & $\begin{array}{l}1991 \\
\% \text { of female } \\
\text { employed }\end{array}$ & $\begin{array}{l}\text { 1991 } \\
\% \text { of total } \\
\text { employment }\end{array}$ & $\begin{array}{c}\text { 1987-1991 } \\
\text { \%-points change } \\
\text { female employed }\end{array}$ \\
\hline Belgium & & & 5.8 \\
Federal Republic of Germany & 45.7 & 30.4 & 7.3 \\
Denmark & 45.5 & 32.5 & -2.8 \\
Greece & 60.2 & 47.2 & -2.0 \\
Spain & 10.3 & 5.1 & -1.4 \\
France & 24.1 & 14.8 & 0.8 \\
Ireland & 36.5 & 27.4 & 1.8 \\
Luxembourg & 32.2 & 20.6 & -1.4 \\
Netherlands & 30.1 & 22.0 & 2.1 \\
Portugal & 77.9 & 63.0 & -1.7 \\
United Kingdom & 19.8 & 13.5 & -1.8 \\
European Union & 67.3 & 50.4 & 0.5 \\
\hline
\end{tabular}

Source: EUROSTAT/ROA

The average proportion of women working part-time in this occupational sector increased by 0.5 percentage points in the period 1987-1991. Just as in the preceding table, half of the Member States show an increase and half show a decrease. The largest increases have been in Belgium and the Federal Republic of Germany, with 5.8 and 7.3 percentage points respectively, and the greatest decreases have been in Denmark and Greece, by 2.8 and 2 percentage points respectively. 
Figure 4.6 showed that two thirds of the total employment in this occupational sector is occupied by women, which again means that only a small number of the part-time jobs are held by men.

In the European Union $23 \%$ of all female 'agricultural, animal husbandry and forestry workers, fishermen and hunters' have part-time jobs, as can be seen in table 4.51. The low percentage of Belgian women working part-time in this occupational sector is remarkable. The percentage in Belgium even lies below that in Portugal. It is also noteworthy that in the Netherlands, again, more than three quarters of all women employed in this occupational sector work part-time. This confirms the implication seen in the two other indicators presented in this chapter, that many female 'service workers' work in the secondary segment of the labour market.

Table 4.51 further shows that the average proportion of women working part-time in this occupational sector increased by just 0.2 percentage points in the period 1987-1991. However there are great differences between the various countries. Six of the ten Member States experienced decreases, while Denmark and the Netherlands had very large increases in the percentage of women working part-time. These two countries had increases of 12.9 and 11.5 percentage points, respectively, whereas the United Kingdom had a decrease of 8.6 percentage points.

Table 4.51. Percentage of female agricultural, animal husbandry and forestry workers, fishermen and hunters (6) working part-time in 1991 and \%-points change in the period 1987-1991

\begin{tabular}{llcc}
\hline & $\begin{array}{l}1991 \\
\% \text { of female } \\
\text { employed }\end{array}$ & $\begin{array}{c}1991 \\
\% \text { of total } \\
\text { employment }\end{array}$ & $\begin{array}{c}1987-1991 \\
\text { \%-points change } \\
\text { female employed }\end{array}$ \\
\hline Belgium & 15.1 & 6.4 & -5.1 \\
Federal Republic of Germany & 32.4 & 16.5 & 2.8 \\
Denmark & 34.3 & 11.0 & 12.9 \\
Greece & 8.4 & 5.0 & -3.2 \\
Spain & 10.1 & 4.6 & -3.2 \\
France & 28.5 & 13.1 & -2.5 \\
Ireland & 32.5 & 5.9 & -7.6 \\
Luxembourg & 29.4 & 7.6 & 10.7 \\
Netherlands & 76.3 & 29.0 & 11.5 \\
Portugal & 17.2 & 13.1 & 6.2 \\
United Kingdom & 40.1 & 9.8 & -8.6 \\
European Union & & 11.0 & 0.2 \\
\hline
\end{tabular}

\section{Source: EUROSTAT/ROA}

Figure 4.7 shows that 1 out 3 persons employed in this occupational sector is female. This indicates that a relatively large number of men must also be working part-time in this occupational sector. 
Finally, table 4.52 shows that $18.6 \%$ of all female 'production and related workers, transport equipment operators and labourers' have part-time jobs. Again Denmark, the Netherlands and the United Kingdom have the highest percentages of women working part-time $137.4 \%, 59.8 \%$ and $43.7 \%$, respectively), whereas Greece, Spain and Portugal again show the smallest percentages $(3.9 \%, 6.1 \%$ and $6.2 \%$ respectively). It is noteworthy that the Federal Republic of Germany has a relatively high percentage of women working part-time, whereas France and Ireland have relatively low percentages.

This occupational sector is the only sector in which the percentage of women working part-time in the European Union decreased between 1987 and 1991. The average figure fell by 0.7 percentage points. Denmark and Spain had the largest decreases, of 7.7 and 3.9 percentage points respectively. Despite the decline in the European average figure for women's part-time work in this sector, five Member States experienced increases in their percentages, with the Federal Republic of Germany and France having the highest increases, of 2.6 and 2.8 percentage points respectively.

Figure 4.8 showed that approximately $15 \%$ of all persons employed in this occupational sector are female. This means that part-time jobs in this occupational sector are also occupied by men.

Table 4.52. Percentage of female production and related workers, transport equipment operators and labourers (7/8/9) working part-time in 1991 and \%-points change in the period 1987-1991

\section{country}

Federal Republic of Germany

Denmark

Greece

Spain

France

Ireland

Luxembourg

Netherlands

Portugal

United Kingdom

European Union

$1991 \quad 1991$

$\%$ of female $\%$ of total employed employment
1987-1991

$\%$-points change female employed

\section{Source: EUROSTAT/ROA}

\subsection{Some concluding remarks}

In this chapter we have analyzed the position of women on the European Union labour market. We saw that women had an employment share of over $40 \%$ in the European Union. Two occupational sectors could be identified as 'typically female'. In the occupational sectors of 
'clerical and related workers' and of 'service workers' women had employment shares of over $60 \%$. On the other hand, in the occupational sectors of 'administrative and managerial workers' and 'production and related workers, transport equipment operators and labourers' women have employment shares of only approximately $25 \%$ and $15 \%$ respectively.

Analyzing the employment growth of women on the European Union labour market, we saw that there were three occupational winners. From table 4.53 it can be seen that over $50 \%$ of the total female workforce is employed in the occupational sectors that can be called occupational winners. The greatest occupational winner in female employment is that of 'professional, technical and related workers' with an increase of 2 percentage points in the period 1987-1991. This means that almost $20 \%$ of the female workforce in the European Union is now employed in this relatively highly-skilled occupational sector. Women are in fact overrepresented in this occupational sector relative to the proportion of total employment which is found in the sector. The 2 percentage point increase in the proportion of women employed in this occupational sector has also been higher than the increase in total employment in this occupational sector, which was 1.5 percentage points (see table 1.1). This means that women have further strengthened their strong position in this occupational sector.

The second occupational winner for women was the sector of 'clerical and related workers'. Although this occupational sector was also an occupational winner for total employment, women were already over-represented in this occupational sector and maintained this position. This occupational sector accounts for the highest proportion of female employment, with $29.4 \%$ of all working women being employed in this sector.

The most surprising occupational winner in female employment is that of 'administrative and managerial workers'. For total employment this occupational sector decreased by 0.2 percentage points (see table 1.5), whereas for female employment it increased by 0.3 percentage points. This indicates that women are catching up with total employment in this occupational sector. However we have to keep in mind that this occupational sector has few workers in relation to the other occupational sectors.

Looking at the occupational losers in female employment, we saw that the losers were almost the same as for total employment. The great exception are the female 'service workers'. Employment for female 'service workers' decreased by 0.7 percentage points, whereas for total employment it increased by 0.2 percentage points (table 1.7). This indicates that the proportions of women employed and total employment in this occupational sector are converging. On the other hand this indicates that women are losing ground in this growth sector in which they traditionally had a leading position. Results for the occupational sector of 'sales workers' indicate that both female and total employment have stabilized. Examining the results in table 4.53, one gets a strong impression that in most occupational sectors the differences between female and total employment (and thus indirectly between female and male employment) are only getting bigger in the European Union. 
Table 4.53. Winners and losers in female employment in the European Union in 1991

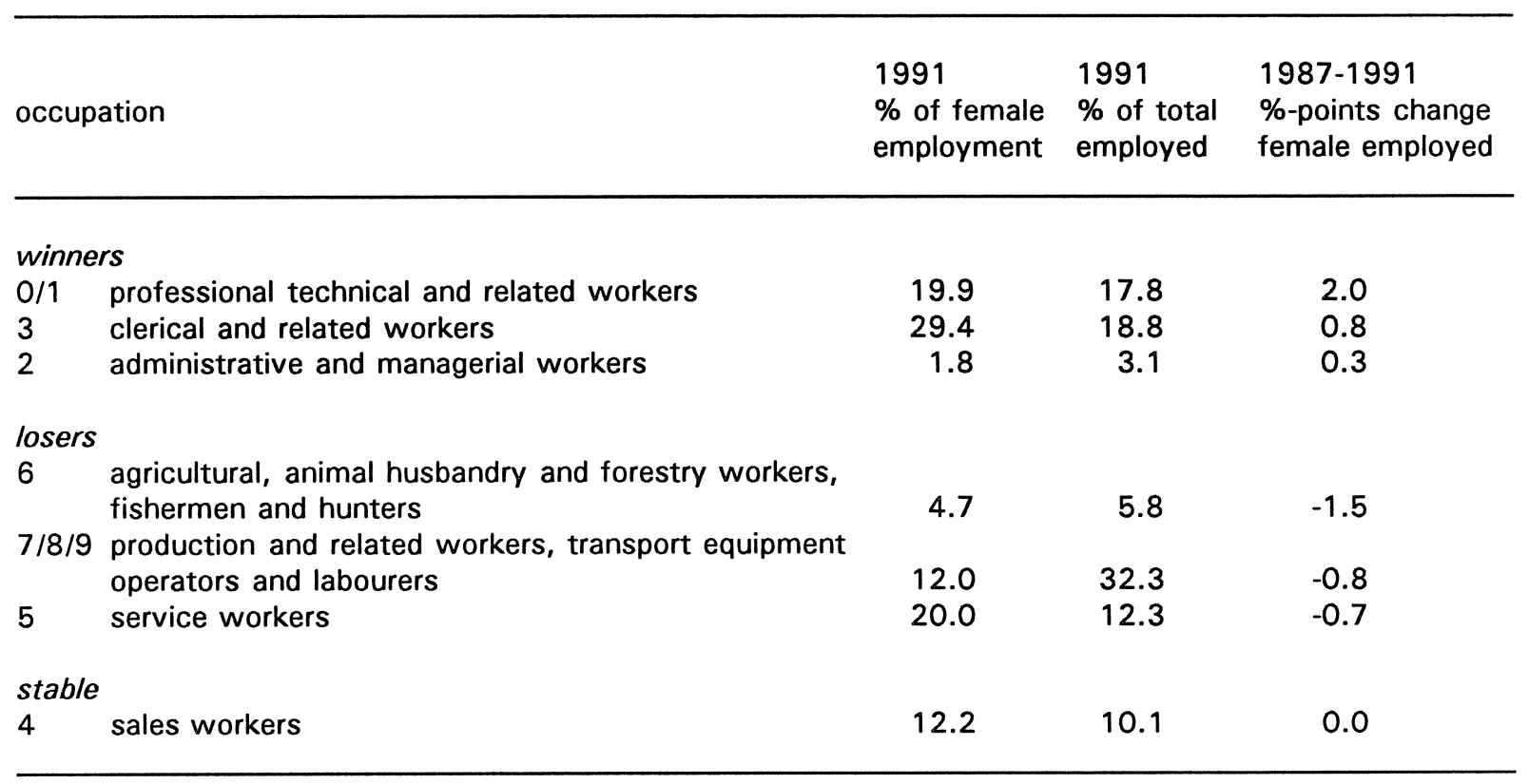

Source: EUROSTAT/ROA

In section 4.3 we analyzed the skill level of women. From figure 4.9 we saw that the educational level of women lay slightly below that of total employment in the European Union. The Federal Republic of Germany, in particular, had an average educational level of women which lay far below that of total employment. We also saw that in Belgium, Spain, Ireland and Portugal the educational level of women was higher than that of total employment.

In general there have been large decreases in the proportions of unskilled and lower skilled women in the European Union and large increases in the proportions of intermediate and highly skilled women. These were strong indications of an upgrading process in female employment in the European Union. This inferred upgrading has led to a change in the educational level of women. Where the 'average' woman was lower skilled in 1987, in 1991 she is intermediate skilled. However, on this point there were large differences between the various Member States. The Southern European countries had very large proportions of unskilled women, but also showed the largest decreases in these proportions. For Greece, Spain and Portugal upgrading refers to the substitution of lower skilled workers for unskilled workers and intermediate skilled workers for the lower skilled. This also indicates that women in these countries are catching up with women in other Member States. If we relate the educational levels of employed women to those of total employment, we see that women are relatively more often educated at the lower level, whereas at all other educational levels women are slightly under-represented. When we looked at a second important indicator of the skill level of women, participation in training, we saw that women's participation in training was the same as for the total workforce. The increase in the proportion of women participating in training, however, has been higher than the figure for all employees 10.9 percentage points to 0.6 percentage points). For women we could also see large differences in the training participation 
rates in the various Member States. We saw that Denmark, the Netherlands and the United Kingdom, in particular, had high training participation rates for women. This indicates that in these three countries training policies are important in upgrading female employment.

In section 4.4 we analyzed female job-seeking and employment relationship stability. Table 4.54 summaries the percentages of both the total and female workforce looking for other jobs, working with a temporary contract and working part-time respectively. Denmark seems to have the least stable employment relationships for women, followed by the Netherlands. In Denmark all three indicators lie above the European Union average, whereas in the Netherlands only two out of three indicators lie above the European average. However, the two indicators that lie above the European average in the Netherlands are much higher than in Denmark. On the other hand Belgium, Greece and Portugal seem to have the most stable employment relationships for women. In Belgium and Greece all three indicators lie below the European averages, while in Portugal two out of the three indicators lie well below the European averages.

Table 4.54. Job-seeking and employment stability for female and total employment in the European Union in 1991

\begin{tabular}{|c|c|c|c|c|c|c|}
\hline \multirow{2}{*}{$\begin{array}{l}\text { country } \\
\text { Belgium }\end{array}$} & \multicolumn{2}{|c|}{ 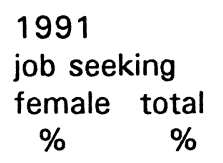 } & \multicolumn{2}{|c|}{ 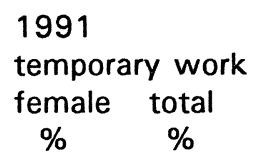 } & \multicolumn{2}{|c|}{$\begin{array}{l}1991 \\
\text { part-time work } \\
\text { female total } \\
\%\end{array} \%$} \\
\hline & 3.6 & 2.2 & 6.6 & 4.0 & 27.4 & 11.7 \\
\hline Federal Republic of Germany & 2.3 & 2.0 & 8.9 & 8.1 & 34.1 & 15.1 \\
\hline Denmark & 7.3 & 6.1 & 11.6 & 10.5 & 37.4 & 22.6 \\
\hline Greece & 2.6 & 2.2 & 8.0 & 7.9 & 6.5 & 3.4 \\
\hline Spain & 2.5 & 1.7 & 28.7 & 24.1 & 11.0 & 4.5 \\
\hline France & 5.7 & 4.6 & 10.5 & 8.7 & 23.4 & 11.9 \\
\hline Ireland & 6.0 & 4.7 & 9.4 & 5.3 & 17.7 & 8.3 \\
\hline Luxembourg & 1.8 & 0.3 & 2.9 & 2.0 & 18.2 & 7.5 \\
\hline Netherlands & 12.2 & 9.9 & 9.3 & 6.7 & 59.9 & 32.4 \\
\hline Portugal & 3.6 & 2.6 & 13.1 & 11.9 & 9.9 & 5.8 \\
\hline United Kingdom & 6.8 & 6.7 & 6.5 & 4.8 & 43.7 & 22.3 \\
\hline European Union & 4.9 & 4.1 & 10.6 & 9.3 & 31.3 & 15.0 \\
\hline
\end{tabular}

Source: EUROSTAT/ROA

When we compare the outcomes of the women employed with those of total employment, we see that all indicators show higher percentages for women. This is a strong indication that employment relationships for women are far less stable than for total employment in all Member States.

Table 4.55 shows the great differences in the stability of women's employment relations in the various occupational sectors. The table shows that female 'administrative and managerial workers' and 'agricultural, animal husbandry and forestry workers, fishermen and hunters' have 
the most stable employment relationships. All three indicators have values below the European average for women. Another stable occupation is that of female 'clerical and related workers'. Although the percentage of women in this sector who are looking for a job is equal to the European average, the two other indicators lie well below the corresponding European averages. The most unstable occupational sector for female employment is that of 'service workers'. In this occupational sector $6.2 \%$ of all women employed are looking for another job, while $13.3 \%$ have temporary contracts and $47.1 \%$ have part-time jobs. All three percentages lie far above the European average. Another rather unstable occupational sector for women is that of 'professional, technical and related workers'.

When we compare the stability of women's employment relationships with that of total employment, the table shows that in most occupational sectors the employment relationships of the female workers are much less stable than for all workers. The exception to this rule seems to be the occupational sector of 'agricultural, animal husbandry and forestry workers, fishermen and hunters'. In this occupational sector, fewer women are looking for another job and fewer have temporary contracts. Only the percentage of women part-time working is above that of total employment in this occupational sector. Generally speaking job satisfaction for women in this occupational sector must be high.

Table 4.55. Job-seeking and employment stability by occupational sector for female and total employment in the European Union in 1991

\begin{tabular}{|c|c|c|c|c|c|c|c|}
\hline \multicolumn{2}{|c|}{ occupation } & \multicolumn{2}{|c|}{$\begin{array}{l}1991 \\
\text { looking } \\
\text { fem. tot. } \\
\% \quad \%\end{array}$} & \multicolumn{2}{|c|}{$\begin{array}{l}1991 \\
\text { temporary } \\
\text { fem. tot. } \\
\% \quad \%\end{array}$} & \multicolumn{2}{|c|}{$\begin{array}{l}1991 \\
\text { part-time } \\
\text { fem tot. } \\
\% \quad \%\end{array}$} \\
\hline $0 / 1$ & professional technical and related workers & 5.1 & 4.6 & 11.7 & 9.1 & 28.6 & 16.0 \\
\hline 2 & administrative and managerial workers & 4.3 & 2.7 & 2.3 & 1.7 & 17.3 & 5.6 \\
\hline 3 & clerical and related workers & 4.9 & 4.5 & 9.3 & 8.4 & 28.0 & 19.3 \\
\hline 4 & sales workers & 4.5 & 4.3 & 9.1 & 7.1 & 35.6 & 20.9 \\
\hline 5 & service workers & 6.2 & 5.7 & 13.3 & 12.3 & 47.1 & 33.8 \\
\hline 6 & $\begin{array}{l}\text { agricultural, animal husbandry and forestry workers, } \\
\text { fishermen and hunters }\end{array}$ & 2.4 & 3.0 & 6.4 & 7.2 & 23.0 & 11.0 \\
\hline $7 / 8 / 9$ & $\begin{array}{l}\text { production and related workers, transport equipment } \\
\text { operators and labourers }\end{array}$ & 4.2 & 3.4 & 12.4 & 10.6 & 18.6 & 4.6 \\
\hline & total & 4.9 & 4.1 & 10.6 & 9.3 & 31.3 & 15.0 \\
\hline
\end{tabular}

Source: EUROSTAT/ROA 


\section{TRENDS IN OCCUPATIONAL EMPLOYMENT OF THIRD AGE WORKERS}

\subsection{Introduction}

This chapter focuses on the group of third age workers, i.e the workers who are between 55 and 64 years of age. As noted in the introduction, the aging of the population is making the position of these third age workers more important. In previous recessions unemployment in many countries was alleviated by early retirement policies for third age workers. In general third age workers were laid of first. Such policies had the advantage that skill obsolescence problems could be circumvented. The expected aging of the labour force is making us more aware of the importance older workers will have in future labour markets. The problem now is that third age workers in most Member States have become accustomed to early retirement schemes. These retirement schemes have even made it more risky for employers to invest in training for older workers.

In 1991 approximately $10 \%$ of the European workforce was aged above 54 years. This is still a relatively low percentage. ${ }^{21}$ However, it is a large enough group to enable us to give an impression, in section 5.2, of the occupational structure of employment for these workers. We will first look at the share these workers have in total employment in the various Member States, differentiated by occupational sectors. Then we will analyze the occupational structure of employment for third age workers and to what extent this differs from the occupational structure of total employment.

In section 5.3 we will analyze job-seeking and the stability of employment relationships for third age workers. We would expect that, given the length of their active working lives, few third age workers would have temporary contracts or be looking for other jobs. We would also expect to find relatively large proportions of third age workers working part-time as a result of partial retirement schemes.

\subsection{The occupational structure of third age employment}

From figure 5.1 we can see that $10.2 \%$ of the total working population in the European Union are over 54 years of age. A striking feature in this figure is that the Southern European countries show the highest employment shares of third age workers (Greece $14.9 \%$, Spain $13.4 \%$ and Portugal $12.8 \%$ ), whereas the Netherlands and Belgium show the lowest shares with $6.2 \%$ and $6.6 \%$ respectively. This suggests a positive relationship between early retirement and social security, which enables third age workers in countries with a developed social security system to retire early. Figures 5.2 to 5.7 largely confirm the picture sketched above.

21. This also means that, due to the small number of workers in many Member States, the data presented is very sensitive to measurement errors. 
Figure 5.1. Employment share of third age workers (total) as a proportion of total national employment in 1991

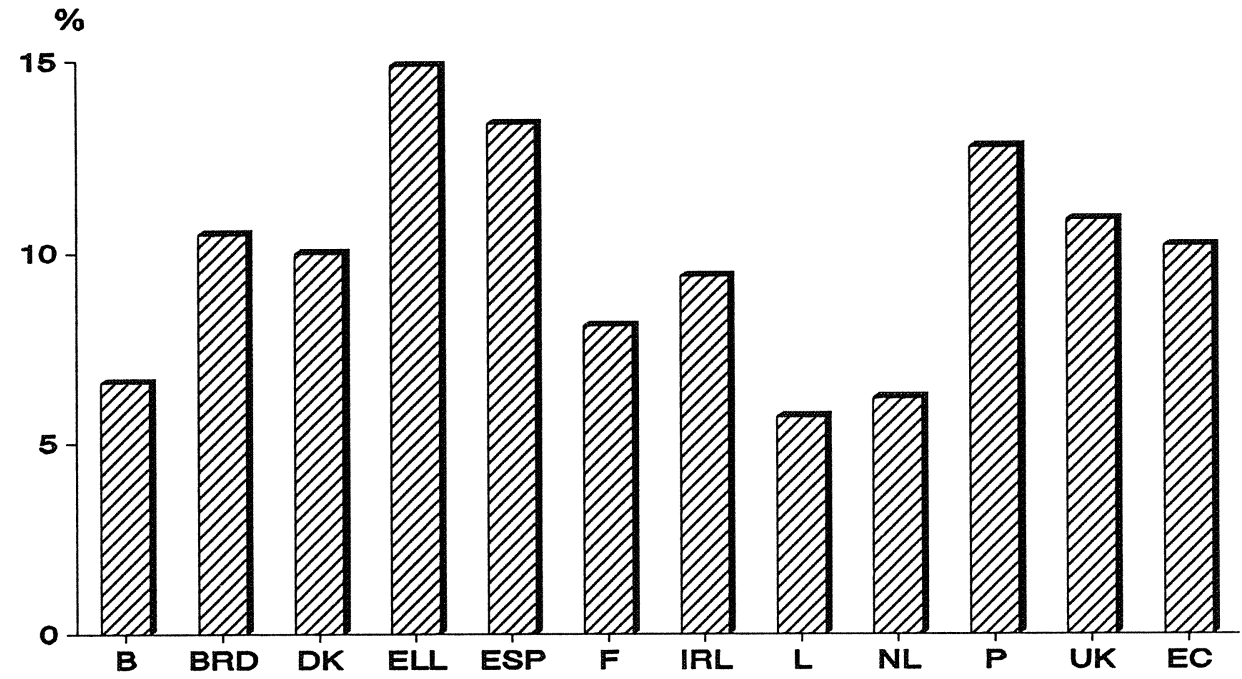

Source: EUROSTAT/ROA

Figure 5.2. Employment share of third age professional, technical and related workers $(0 / 1)$ as a proportion of total employment in this occupational sector in 1991

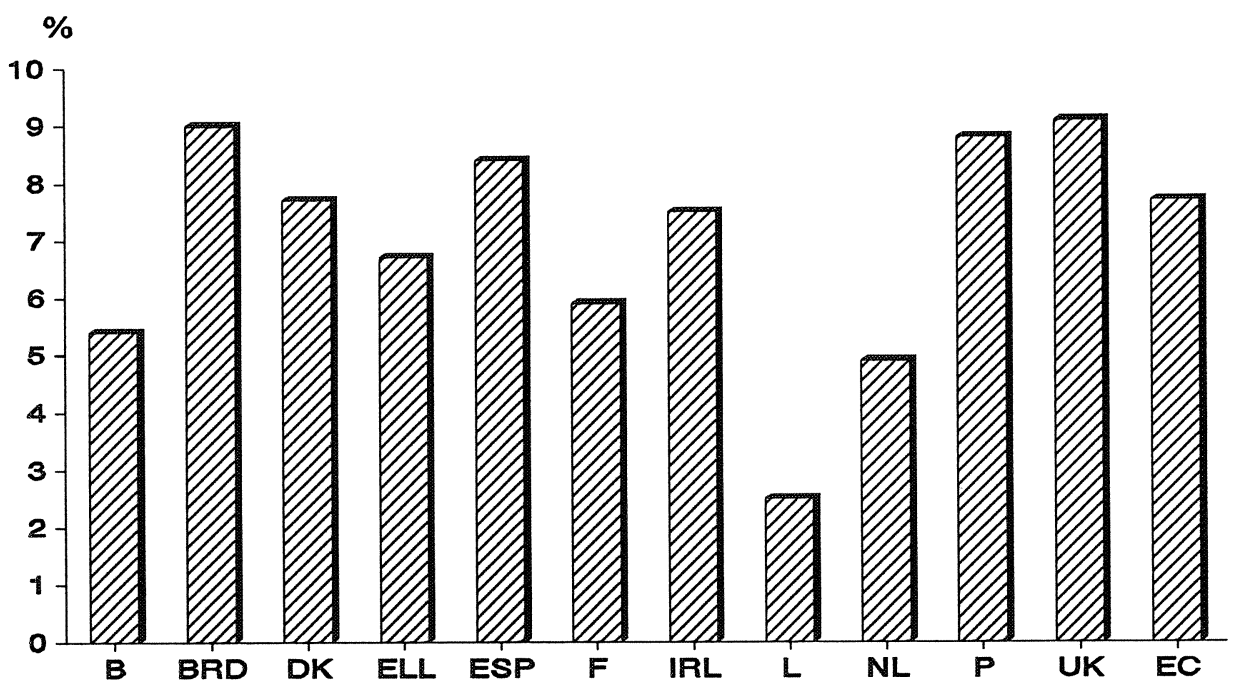

Source: EUROSTAT/ROA 
Figure 5.3. Employment share of third age administrative and managerial workers (2) as a proportion of total employment in this occupational sector in 1991

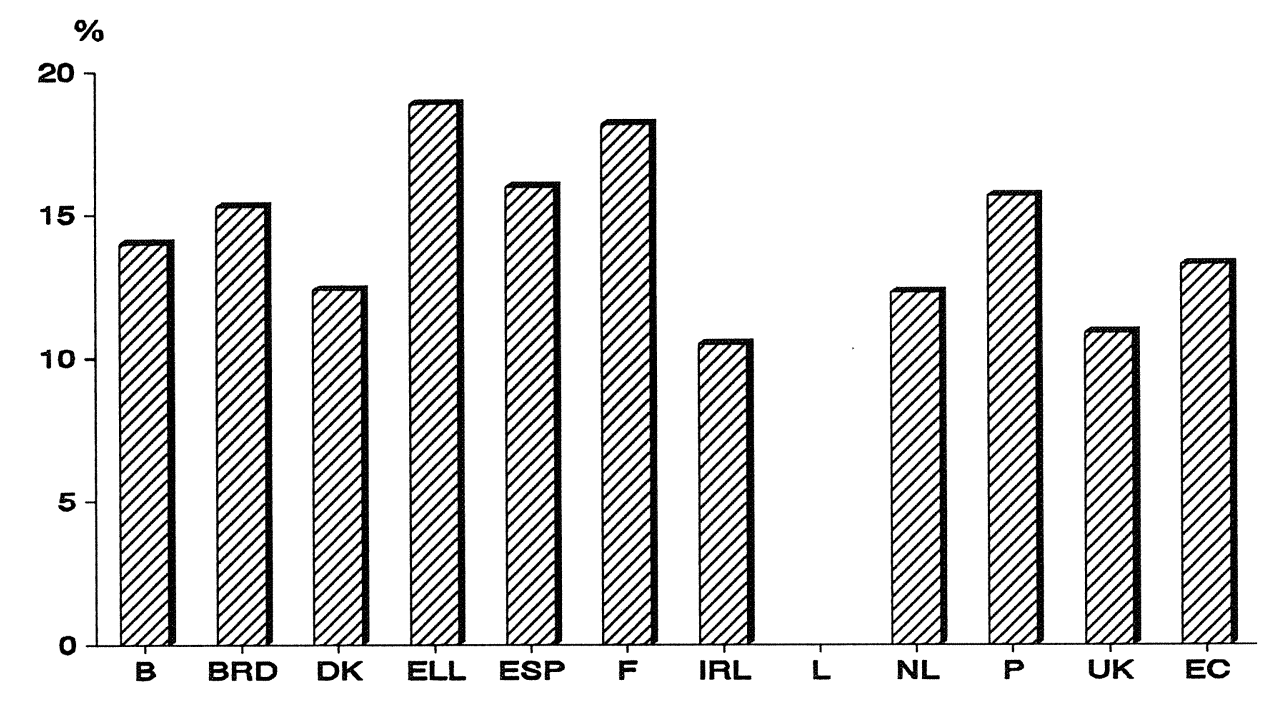

Source: EUROSTAT/ROA

Figure 5.4. Employment share of third age clerical and related workers (3) as a proportion of total employment in this occupational sector in 1991

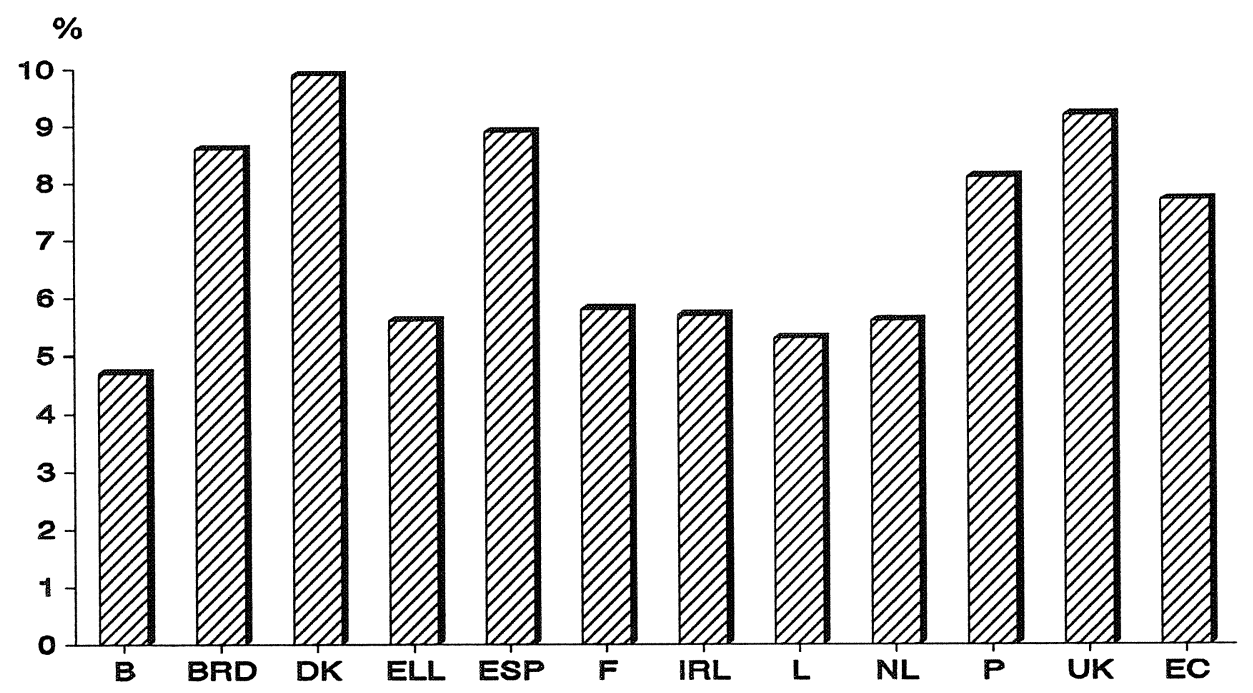

Source: EUROSTAT/ROA 
Figure 5.5. Employment share of third age sales workers (4) as a proportion of total employment in this occupational sector in 1991

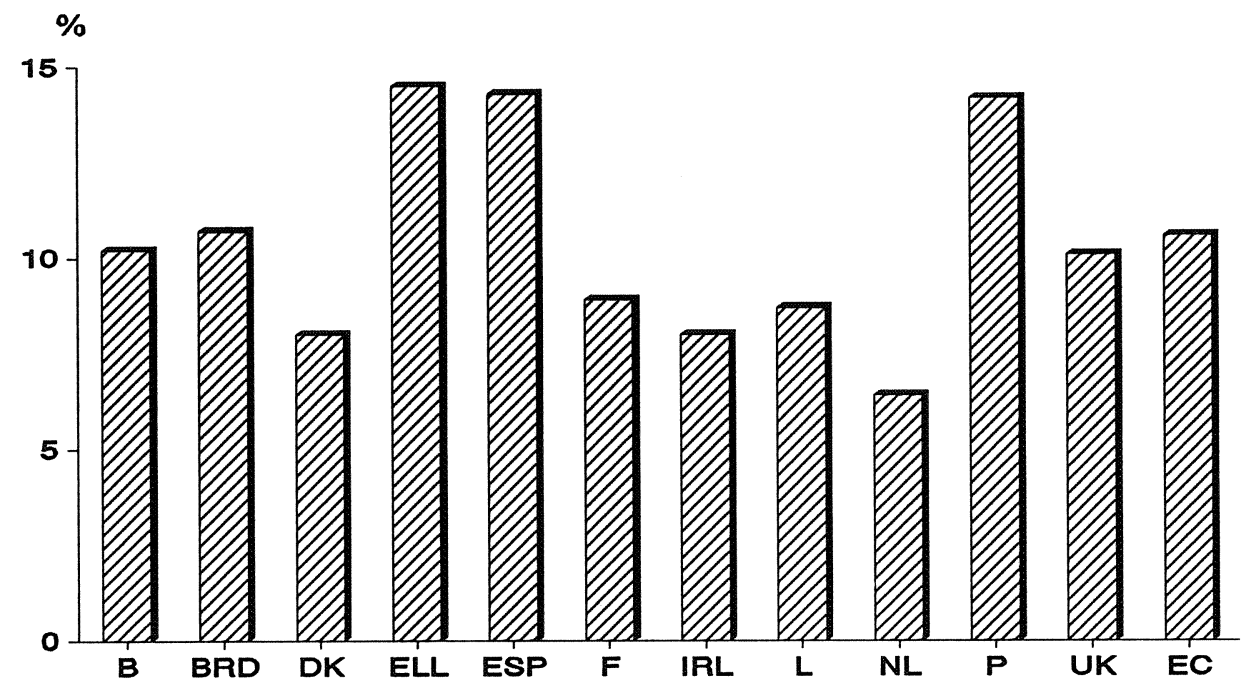

Source: EUROSTAT/ROA

Figure 5.6. Employment share of third age service workers (5) as a proportion of total employment in this occupational sector in 1991

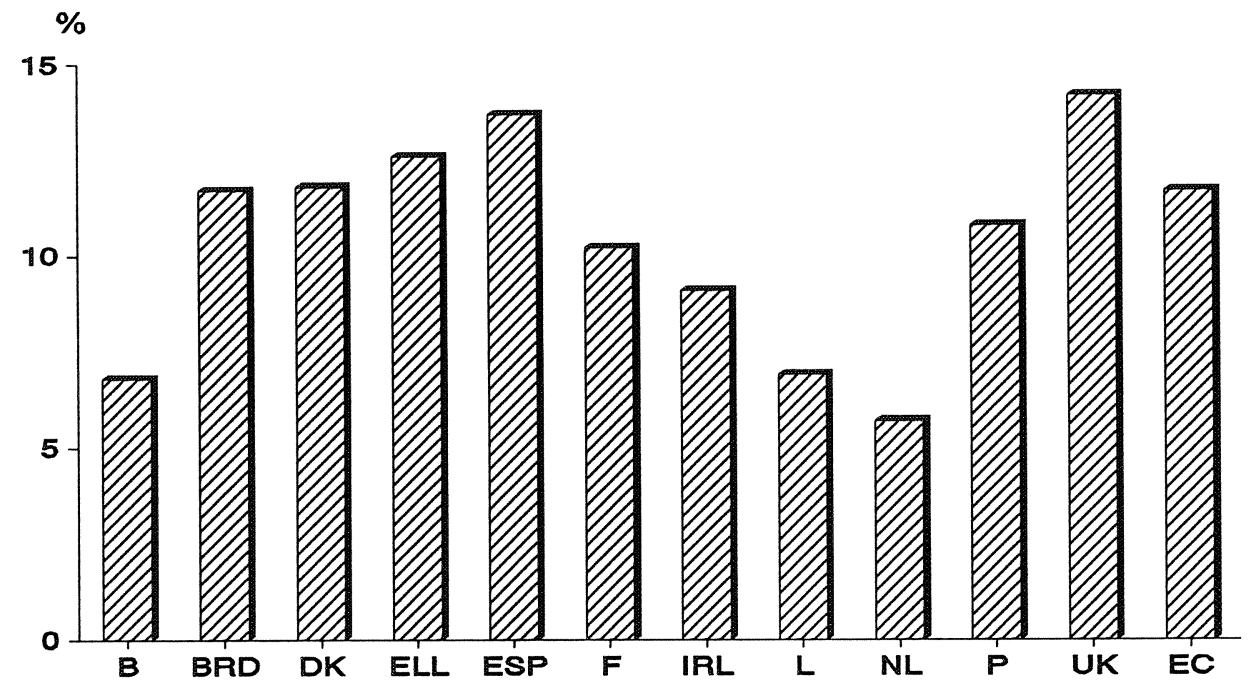

Source: EUROSTAT/ROA 
Figure 5.7. Employment share of third age agricultural, animal husbandry and forestry workers, fishermen and hunters (6) as a proportion of total employment in this occupational sector in 1991

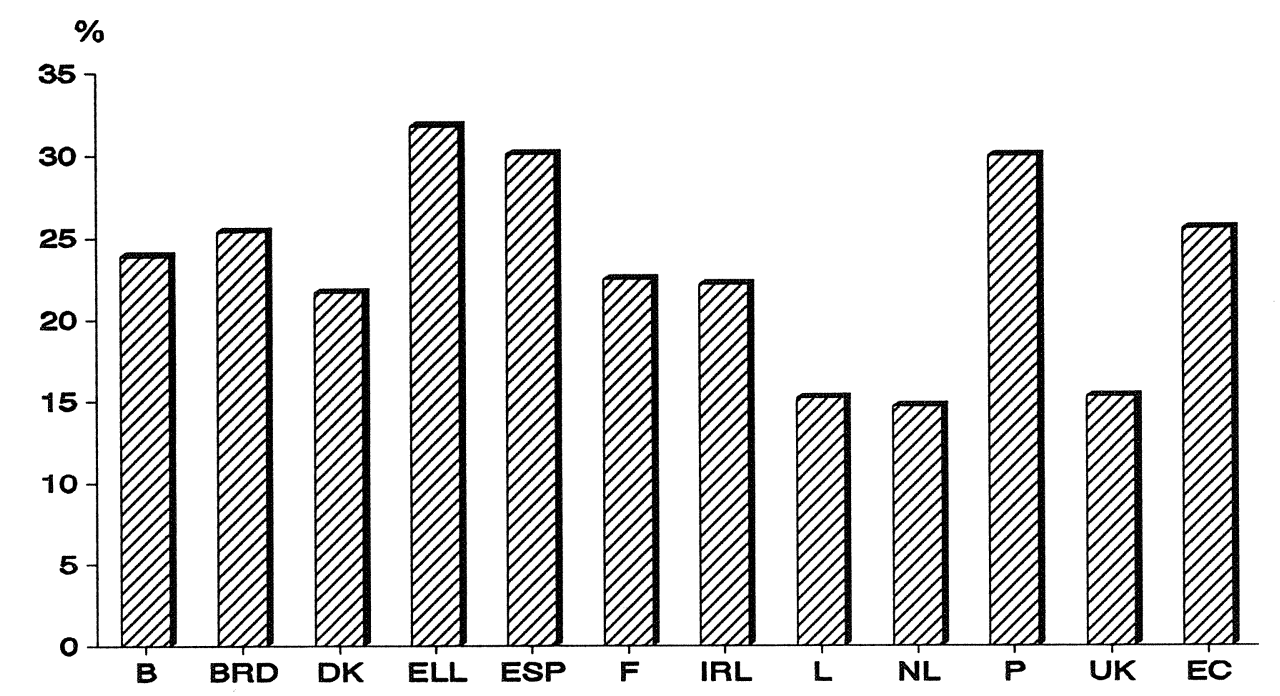

Source: EUROSTAT/ROA

Figure 5.8. Employment share of third age production-related workers, transport equipment operators and labourers $(7 / 8 / 9)$ as a proportion of total employment in this occupational sector in 1991

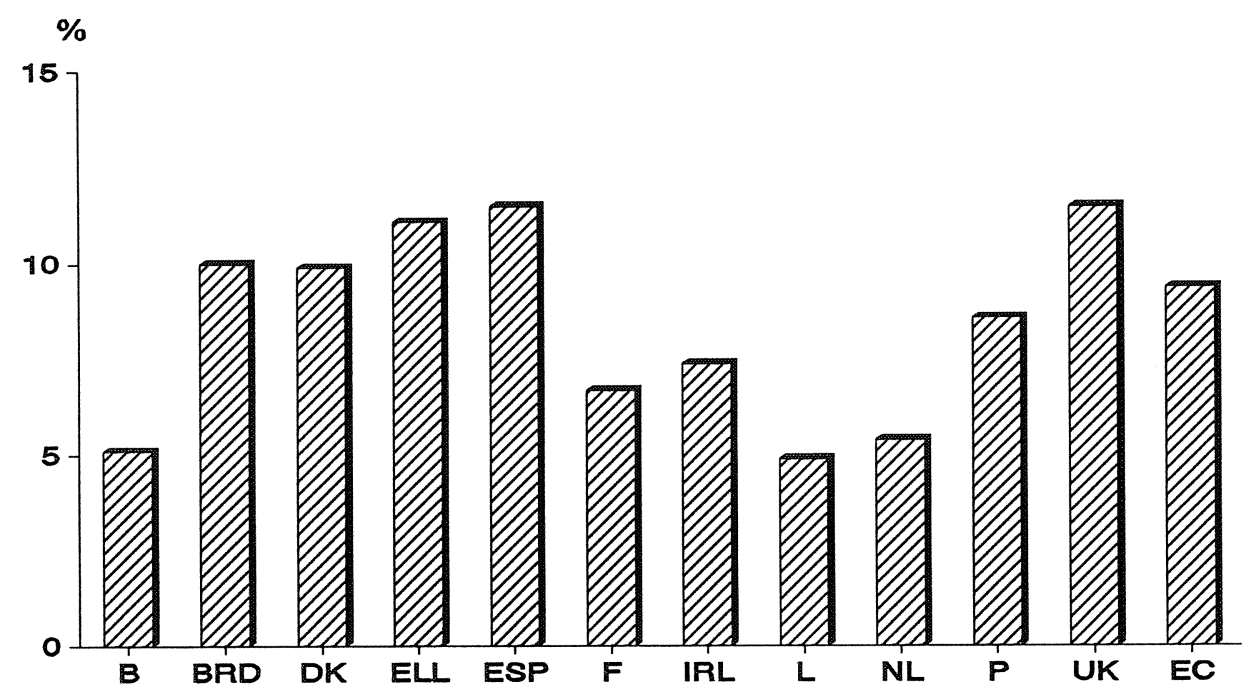

Source: EUROSTAT/ROA

However, there is one occupational sector in which their employment share is strikingly high. Figure 5.7 shows that in the European Union third age workers have an employment share of more than $25 \%$ in the occupational sector of 'agricultural, animal husbandry and forestry workers, fishermen and hunters'. Only in the Netherlands and the United Kingdom do third age 
workers have employment shares in this occupational sector below $20 \%$. On the other hand, Greece, Spain and Portugal show percentages of over $30 \%$. This may be because the worsening prospects of this occupational sector make agricultural work unattractive for younger workers.

Winners on the European labour market for third age workers.

Three occupational sectors can be identified as occupational winners for third age workers. These are the 'professional, technical and related workers', the 'production and related workers, transport equipment operators and labourers' and the 'service workers'. The position of the 'production and related workers, transport equipment operators and labourers' is especially remarkable, as this sector is for both total employment and female employment an occupational loser. This indicates the ageing of the workforce in this occupational sector.

Table 5.1 shows that on average $29.7 \%$ of the third age workforce are employed in the occupational sector of 'production and related workers, transport equipment operators and labourers'. This means that this occupational sector offers the highest employment for older workers. Only Denmark and the United Kingdom have percentages close to the European average in this occupational sector. In the other countries the percentages range from only $21.4 \%$ in the Netherlands to $33.2 \%$ in the Federal Republic of Germany. Other countries with a relatively small percentage of the third age working population employed in this occupational sector are Belgium (24\%), Greece (23.1\%), Ireland $(22.8 \%)$ and Portugal $(24.6 \%)$.

The proportion of third age workers employed in this occupational sector increased by 1.7 percentage points for the European Union in the period 1987-1991. France and Spain had the highest increases, of 4.1 and 3.3 percentage points respectively. Remarkably, in Belgium and the Netherlands the percentages of the third age workforce employed in this occupational decreased by 1.1 and 0.4 percentage points, respectively, although these countries already had very low percentages.

When we relate the proportion of third age employment in this occupational sector to this sector's share in total employment, we can see that older workers are relatively underrepresented. Especially in Belgium, Greece, Spain, France, Ireland and, most of all, Portugal, older workers are very much under-represented in this occupational sector. The United Kingdom is the only country showing a percentage of the third age working population that is higher than the sector's share of total national employment.

The second occupational winner is the occupational sector of 'professional technical and related workers' (see table 5.2). On average $13.3 \%$ of all third age workers are employed in this occupational sector. Denmark has the largest proportion of its third age workforce employed in this occupational sector, with $20.2 \%$. Other countries with relatively large proportions of the third age workforce employed in this occupational sector are Belgium and the Netherlands. Greece, Spain and Portugal show very low proportions of the third age working population employed in this occupational sector, with $5.9 \%, 7.1 \%$ and $6.7 \%$ respectively. 
Table 5.1. Third age production and related workers, transport equipment operators and labourers (7/8/9) as a percentage of total third age employment in 1991 and \%-points change in the period 1987-1991

\begin{tabular}{llll}
\hline country & $\begin{array}{l}1991 \\
\% \text { of third age } \\
\text { employed }\end{array}$ & $\begin{array}{l}\text { 1991 } \\
\% \text { of total } \\
\text { employment }\end{array}$ & $\begin{array}{l}\text { 1987-1991 } \\
\text { \%-points change } \\
\text { third age employed }\end{array}$ \\
\hline Belgium & 24.0 & 31.2 & -1.1 \\
Federal Republic of Germany & 33.2 & 34.7 & 0.9 \\
Denmark & 31.5 & 31.5 & 1.9 \\
Greece & 23.1 & 30.9 & 2.6 \\
Spain & 32.5 & 38.0 & 3.3 \\
France & 25.9 & 31.1 & 4.1 \\
Ireland & 22.8 & 28.8 & 1.7 \\
Luxembourg & 28.9 & 33.4 & -2.9 \\
Netherlands & 21.4 & 24.4 & 0.4 \\
Portugal & 24.6 & 36.6 & 0.9 \\
United Kingdom & 31.0 & 29.3 & 0.3 \\
European Union & & 32.3 & 1.7 \\
\hline
\end{tabular}

Source: EUROSTAT/ROA

Table 5.2. Third age professional, technical and related workers $(0 / 1)$ as a percentage of total third age employment in 1991 and \%-points change in the period 1987-1991

\begin{tabular}{lccc}
\hline country & $\begin{array}{l}1991 \\
\% \text { of third age } \\
\text { employed }\end{array}$ & $\begin{array}{l}1991 \\
\% \text { of total } \\
\text { employment }\end{array}$ & $\begin{array}{c}1987-1991 \\
\text { \%-points change } \\
\text { third age employed }\end{array}$ \\
\hline Belgium & 18.6 & 22.6 & 3.3 \\
Federal Republic of Germany & 15.7 & 18.3 & 0.5 \\
Denmark & 20.2 & 26.1 & 1.8 \\
Greece & 5.9 & 13.1 & 1.3 \\
Spain & 7.1 & 11.4 & 0.1 \\
France & 13.8 & 18.9 & 1.6 \\
Ireland & 13.1 & 16.4 & 2.2 \\
Luxembourg & 5.6 & 12.7 & -7.5 \\
Netherlands & 19.0 & 24.2 & -0.5 \\
Portugal & 6.7 & 9.7 & 1.3 \\
United Kingdom & 15.4 & 18.4 & 1.2 \\
European Union & 13.3 & 17.8 & 0.9 \\
\hline
\end{tabular}

\section{Source: EUROSTAT/ROA}

On average the proportion of third age workers employed in this occupational sector increased by 0.9 percentage points. Belgium and Ireland show the largest increases, of 3.3 and 2.2 percentage points respectively. The Netherlands is the only country in which the proportion of the third age working population employed in this occupational sector decreased. 
When we relate the average proportion of third age workers to this sector's share in total employment, we see again that third age workers are under-represented in this occupational sector. All Member States show a more or less similar under-representation of older workers in this occupational sector.

The last winner with regard to older workers employed, is the occupational sector of 'service workers' (see table 5.3). In the European Union 14\% of all older workers are employed in this occupational sector. Only in France and the United Kingdom is the proportion above this average. Greece is the only country in which the proportion is very much below average, at $7.9 \%$. All other Member States show proportions between 10 and $12 \%$.

The average proportion of third age workers employed in this occupational sector increased by 0.5 percentage points in the period 1987-1991. France and the United Kingdom show the highest increases, of 1.3 and 1.5 percentage points respectively. However, the decrease in the proportion of Danish third age workers employed in this occupational sector, of 3.2 percentage points, is more remarkable. Other countries showing a decrease are Spain 10.2 percentage points) and the Netherlands (0.9 percentage points).

Table 5.3. Third age service workers (5) as a percentage of total third age employment in 1991 and \%points change in the period 1987-1991

\begin{tabular}{lccc}
\hline Country & $\begin{array}{l}1991 \\
\% \text { of third age } \\
\text { employed }\end{array}$ & $\begin{array}{c}1991 \\
\% \text { of total } \\
\text { employment }\end{array}$ & $\begin{array}{c}\text { 1987-1991 } \\
\text { \%-points change } \\
\text { third age employed }\end{array}$ \\
\hline Belgium & 10.6 & 10.4 & 0.8 \\
Federal Republic of Germany & 10.8 & 9.7 & 0.8 \\
Denmark & 10.8 & 9.2 & -3.2 \\
Greece & 7.9 & 9.3 & 0.1 \\
Spain & 14.0 & 13.7 & -0.2 \\
France & 17.6 & 14.0 & 1.3 \\
Ireland & 11.3 & 11.8 & 0.4 \\
Luxembourg & 16.7 & 13.7 & 0.8 \\
Netherlands & 11.4 & 12.5 & -0.9 \\
Portugal & 10.6 & 12.6 & 0.2 \\
United Kingdom & 18.3 & 14.0 & 1.5 \\
European Union & 14.0 & 12.3 & 0.5 \\
\hline
\end{tabular}

Source: EUROSTAT/ROA

When we compare the proportion of the third age workforce employed in this occupational sector with this sector's share in total employment, we see that older workers are slightly overrepresented in this sector. However, this is not applicable to all Member States, as Greek, Irish, Dutch and Portuguese third age workers are slightly under-represented in this occupational sector. 
Losers on the labour market for third age workers

At the European Union level, there were two occupational losers as regards third age workers: 'agricultural, animal husbandry and forestry workers, fishermen and hunters' and 'administrative and managerial workers'. The first of these was also a loser for total and female employment, whereas the latter was stable for the total workforce and a very small winner for female employment.

Table 5.4 shows that $14.4 \%$ of the third age workforce in the European Union is employed in the occupational sector of 'agricultural, technical and related workers'. The range between the smallest and largest proportions is enormous. The United Kingdom has the smallest proportion with $2.9 \%$, while Greece has the largest proportion with $44.9 \%$. Ireland and Portugal also have very large proportions of third age employment in this occupational sector, with proportions of over $30 \%$.

The proportion of third age workers employed in this occupational sector in the European Union decreased by 2.6 percentage points in the period 1987-1991. All Member States show decreasing proportions of the third age workforce employed in this occupational sector. The countries with the highest proportions also show the largest decreases.

Table 5.4. Third age agricultural, animal husbandry and forestry workers, fishermen and hunters (6) as a percentage of total third age employment in 1991 and \%-points change in the period 19871991

\begin{tabular}{lllc}
\hline & 1991 & 1991 & $1987-1991$ \\
country & $\begin{array}{l}\text { \% of third age } \\
\text { employed }\end{array}$ & $\begin{array}{l}\text { \% of total } \\
\text { employment }\end{array}$ & $\begin{array}{c}\text { \%-points change } \\
\text { third age employed }\end{array}$ \\
\hline
\end{tabular}

$\begin{array}{lrrr}\text { Belgium } & 9.9 & 2.7 & -0.5 \\ \text { Federal Republic of Germany } & 8.4 & 3.5 & -2.2 \\ \text { Denmark } & 9.1 & 4.2 & -0.5 \\ \text { Greece } & 44.9 & 21.0 & -4.9 \\ \text { Spain } & 23.4 & 10.4 & -3.6 \\ \text { France } & 17.5 & 6.3 & -5.5 \\ \text { Ireland } & 30.2 & 12.8 & -3.9 \\ \text { Luxembourg } & 11.1 & 4.2 & 1.8 \\ \text { Netherlands } & 10.4 & 4.4 & -1.0 \\ \text { Portugal } & 35.9 & 15.4 & -3.5 \\ \text { United Kingdom } & 2.9 & 2.0 & -1.3 \\ & & & -2.6\end{array}$

\section{Source: EUROSTAT/ROA}

Table 5.4 also shows a very large gap between the proportion of third age workers employed in this occupational sector, and this sector's share in total employment. For all Member States we see that older workers are strongly over-represented. As we saw in figure 5.7 , in this 
occupational sector the ageing of the workforce is by far the greatest of all occupational sectors.

Table 5.5 shows the other occupational loser: 'administrative and managerial workers'. Of all third age workers in the European Union, $4 \%$ work in this occupational sector. Greece, Spain, France and Portugal show small proportions of older workers employed in this occupational sector, whereas Belgium and the Netherlands show high proportions.

The proportion of older workers employed in this occupational sector decreased by 0.7 percentage points in the period 1987-1991. Five countries show decreases, and five show increases. The United Kingdom has the largest decrease, at 2.4 percentage points. Denmark has the highest increase, with 3.8 percentage points. As has been said before, we have to be very careful in interpreting developments in this occupational sector, because of the problems in defining this occupational sector and the very small numbers of third age workers employed in this sector in the various Member States, which makes the data very liable to measurement errors.

Table 5.5. Third age administrative and managerial workers (2) as a percentage of total third age employment in 1991 and \%-points change in the period 1987-1991

\begin{tabular}{lllc}
\hline country & $\begin{array}{l}\text { 1991 } \\
\text { \% of third age } \\
\text { employed }\end{array}$ & $\begin{array}{l}1991 \\
\% \text { of total } \\
\text { employment }\end{array}$ & $\begin{array}{c}\text { 1987-1991 } \\
\% \text {-points change } \\
\text { third age employed }\end{array}$ \\
\hline Belgium & 8.8 & 4.2 & -0.7 \\
Federal Republic of Germany & 5.0 & 3.5 & -0.7 \\
Denmark & 5.8 & 4.7 & 3.8 \\
Greece & 2.1 & 1.7 & -0.7 \\
Spain & 2.2 & 1.9 & 0.2 \\
France & 0.8 & 0.4 & -0.3 \\
Ireland & 4.0 & 3.7 & 0.5 \\
Luxembourg & - & 1.0 & 0.0 \\
Netherlands & 9.3 & 4.7 & 1.5 \\
Portugal & 2.5 & 2.0 & 0.6 \\
United Kingdom & 5.4 & 5.4 & -2.4 \\
European Union & & 3.1 & -0.7 \\
\hline
\end{tabular}

\section{Source: EUROSTAT/ROA}

When we relate the proportion of third age workers employed in this occupational sector to this sector's share of total employment, we see that older workers are slightly over-represented, which is quite plausible as, within internal labour markets, many workers only reach jobs at managerial level after a certain tenure. In Belgium and the Netherlands the over-representation is very large, whereas in the other Member States the proportions of third age workers are only slightly higher than the percentage of the total workforce employed in this occupational sector. 


\section{Stable occupations}

The occupational sectors of 'clerical and related workers' and of 'sales workers' can be identified as stable occupations. The first sector was also a stable occupation for both women and total employment. The latter proved to be an occupational loser for women and appeared to be stable for total employment.

From table 5.6 we can see that $14.2 \%$ of the third age working population is employed in the occupational sector of 'clerical and related workers. The Federal Republic of Germany, the Netherlands and the United Kingdom show high proportions of older workers employed in this occupational sector with $17.3 \%, 17 \%$ and $16.6 \%$ respectively, whereas Greece, Spain, Ireland and Portugal show much lower proportions $(4.5 \%, 8.8 \%, 9.5 \%$ and $8.7 \%)$.

The average decrease in the proportion of the third age workforce employed in this occupational sector amounted to 0.1 percentage points for the period 1987-1991. This average tendency has been caused by opposing trends. Five Member States show an increase, and five experienced a decrease.

Table 5.6. Third age clerical and related workers (3) as a percentage of total third age employment in 1991 and \%-points change in the period 1987-1991

\begin{tabular}{lccc}
\hline country & $\begin{array}{c}1991 \\
\% \text { of third age } \\
\text { employed }\end{array}$ & $\begin{array}{c}1991 \\
\% \text { of total } \\
\text { employment }\end{array}$ & $\begin{array}{c}1987-1991 \\
\% \text {-points change } \\
\text { third age employed }\end{array}$ \\
\hline Belgium & 14.2 & 20.0 & -2.1 \\
Federal Republic of Germany & 17.3 & 21.0 & 0.0 \\
Denmark & 15.9 & 16.1 & -2.3 \\
Greece & 4.5 & 12.0 & 1.4 \\
Spain & 8.8 & 13.3 & 0.1 \\
France & 14.7 & 20.5 & -0.2 \\
Ireland & 9.5 & 15.8 & 0.0 \\
Luxembourg & 24.4 & 26.2 & 4.8 \\
Netherlands & 17.0 & 18.8 & 0.4 \\
Portugal & 8.7 & 12.8 & -0.1 \\
United Kingdom & 16.6 & 19.6 & -0.2 \\
European Union & 14.2 & 18.8 & -0.1 \\
\hline
\end{tabular}

Source: EUROSTAT/ROA

Comparing the proportion of the third age working population in this occupational sector to this sectors' share in total employment shows that third age workers are under-represented. Especially, Belgium, Greece, Spain, France and Ireland show very large gaps. In the Netherlands and Denmark, however, the gaps are very small. 
Table 5.7 shows the other occupational sector with rather stable employment for older workers. In the European Union $10.4 \%$ of the third age workforce is employed in the occupational sector of 'sales workers'. Belgium and Spain show relatively high proportions of older workers employed in this occupational sector $(13.9 \%$ and $12.1 \%)$, whereas Denmark has a very small proportion (6.7\%). All other Member States have proportions which are close to the average for the total workforce.

Table 5.7. Third age sales workers (4) as a percentage of total third age employment in 1991 and \%points change in the period 1987-1991

\begin{tabular}{lccc}
\hline country & $\begin{array}{l}1991 \\
\text { \% of third age } \\
\text { employed }\end{array}$ & $\begin{array}{l}\text { 1991 } \\
\text { \% of total } \\
\text { employment }\end{array}$ & $\begin{array}{c}\text { 1987-1991 } \\
\text { \%-points change } \\
\text { third age employed }\end{array}$ \\
\hline Belgium & 13.9 & 9.0 & 0.3 \\
Federal Republic of Germany & 9.5 & 9.4 & 0.6 \\
Denmark & 6.7 & 8.3 & -1.4 \\
Greece & 11.6 & 11.9 & 0.1 \\
Spain & 12.1 & 11.3 & 0.1 \\
France & 9.8 & 8.9 & -1.0 \\
Ireland & 9.1 & 10.7 & -0.9 \\
Luxembourg & 13.3 & 8.8 & 3.1 \\
Netherlands & 11.5 & 11.1 & 0.9 \\
Portugal & 11.0 & 10.0 & 0.6 \\
United Kingdom & 10.5 & 11.3 & 0.9 \\
European Union & 10.4 & 10.1 & 0.2 \\
\hline
\end{tabular}

Source: EUROSTAT/ROA

In the period 1987-1991 the average proportion of third age workers employed in this occupational sector increased by 0.2 percentage points. The Netherlands and the United Kingdom had the highest increases, both of 0.9 percentage points. However, in three countries the proportion of the third age working population employed in this occupational sector decreased. In Denmark, France and Ireland the decreases were 1.4, 1 and 0.9 percentage points respectively.

When we compare the proportion of the third age workforce employed in this occupational sector with this sectors' share in total employment, we see that these shares are more or less equal. Only Belgium has a large over-representation of older workers.

\subsection{Job-seeking and the stability of third age workers' employment relationships}

\section{Job-seeking}

From table 5.8 we can see that only $1.3 \%$ of third age workers are looking for another job. This produced such small numbers for individual countries that we have confined the analysis to the European Union level, distinguished by occupational sectors. However the results for 
'administrative and managerial workers', in particular, are still very dubious, as this occupational sector employs only 0.4 million older workers in the whole European Union.

Table 5.8. Third age workers' job-seeking in the European Union in 1991 and \%-points change in the period 1987-1991

\begin{tabular}{|c|c|c|c|}
\hline occupation & $\begin{array}{l}1991 \\
\% \text { of third age } \\
\text { employment }\end{array}$ & $\begin{array}{l}1991 \\
\% \text { of total } \\
\text { employed }\end{array}$ & $\begin{array}{l}1987-1991 \\
\% \text {-points change } \\
\text { female employed }\end{array}$ \\
\hline
\end{tabular}

\begin{tabular}{lllll}
$0 / 1$ & professional, technical and related workers & 1.4 & 4.6 & -0.4 \\
2 & administrative and managerial workers & 2.4 & 2.7 & -0.5 \\
3 & clerical and related workers & 1.3 & 4.5 & 0.3 \\
4 & $\begin{array}{l}\text { sales workers } \\
5\end{array} \quad \begin{array}{l}\text { service workers } \\
\text { agricultural, animal husbandry and forestry }\end{array}$ & 1.4 & 4.3 & -0.0 \\
$\quad \begin{array}{l}\text { workers fishermen and hunters } \\
\text { production and related workers, transport } \\
\quad \text { equipment operators and labourers }\end{array}$ & 1.2 & 5.7 & -0.6 \\
& 1.2 & 3.0 & -0.0 \\
$\quad$ total & 1.3 & 3.4 & -0.3 \\
\hline
\end{tabular}

Source: EUROSTAT/ROA

Apart from the occupational sector of 'administrative and managerial workers', the percentages for the various occupational sectors lie within a range of just $0.3 \%$. This is an indication of the stable employment relationships of most older workers.

The table also shows that in most occupational sectors the proportion of third age workers who are looking for another job decreased slightly. However, the clerical and related workers seem to be the exception to this rule, as this sector shows a small increase in the proportion of older job-seekers.

When comparing the results for third age workers to those for total employment, we see that third age workers are very much less active in seeking different jobs than the total working population. The occupational sector of 'service workers' shows an especially large difference. One reason for this large difference may be that some of the older people employed in this occupational sector in fact own the often small businesses in which they work.

\section{Temporary contracts}

Here too the percentage of third age workers with a temporary work contract has been used as a second indicator of employment relationship stability. Table 5.9 shows that only $4.7 \%$ of the total third age workforce have temporary contracts in the European Union. The table also shows that there are relatively large differences between the different occupational sectors. The third age 'sales workers' have the smallest incidence of temporary contracts, at only $2 \%$, while the 'professional, technical and related workers' have the highest rate, at $5.9 \%$. The third age 
'service workers' and 'production and related workers, transport equipment operators and labourers' are also relatively likely to have temporary contracts, whereas only a few third age 'clerical and related workers' are contracted on a temporary basis.

The table also shows that the proportion of third age workers with temporary contracts increased by 1.1 percentage points in the period 1987-1991. Again there are large differences between the various occupational sectors. The 'service workers' saw an increase of 2.5 percentage points, which means that the proportion of third age workers with temporary contracts almost doubled in this occupational sector. The occupational sectors of 'clerical and related workers' and 'sales workers', on the other hand, show only small increases.

If we relate the proportion of third age workers with temporary contracts to the figure for the total workforce, we see that the percentage for third age workers is about half that of the total workforce. This is in accordance with what could be expected on basis of both the human capital theory (older workers have more firm-specific human capital) and the labour market segmentation theory (older workers more often have stable employment relationships within internal labour markets). Especially in the occupational sectors of 'clerical and related workers' and of 'sales workers', the differences are very large. In the occupational sector of 'administrative and managerial workers' the percentage of third age workers with temporary jobs is even higher than that for total employment. ${ }^{22}$

Table 5.9. Temporary contracts of third age workers in the European Union in 1991 and \%-points change in the period 1987-1991

occupation

1991

$\%$ of third age

employment
1991

$\%$ of total employed
1987-1991

\%-points change female employed
0/1 professional technical and related workers

2 administrative and managerial workers

\section{9}

clerical and related workers

sales workers

service workers

agricultural, animal husbandry and forestry workers fishermen and hunters

$7 / 8 / 9$ production and related workers, transport equipment operators and labourers

total

\section{3}

3.2

2.0

5.4

4.1

5.1

4.7
9.1

1.7

8.4

7.1

12.3

7.2

10.6

9.3
1.7

0.0

0.6

0.4

2.5

1.0

1.0

1.1

Source: EUROSTAT/ROA

22. Here we have to keep in mind, however, that $3.3 \%$ of the third age 'administrative and managerial workers' refers to just 14,000 people. 


\section{Part-time work}

Part-time work has been used as a third indicator of the stability of employment relationships. Particularly from the third age worker's point of view, part-time work is an ideal opportunity to withdraw gradually from the labour market. This can be illustrated by table 5.10 , which shows that $17.3 \%$ of the total third age workforce is working part-time. For 'service workers' the parttime employment rate is as high as $40.9 \%$. On the other hand only $5.9 \%$ of the older workers employed in the occupational sector of 'production and related workers, transport equipment operators and labourers' are working part-time. Thus the differences between the various occupational sectors are very large.

The proportion of older workers with part-time jobs in the European Union increased by 1.5 percentage points in the period 1987-1991. Again the 'service workers' show the largest increase in the proportion of elderly employees working part-time. The occupational sectors of 'sales workers', of 'agricultural, animal husbandry and forestry workers, fishermen and hunters' and of 'production and related workers, transport equipment operators and labourers' show only very small increases.

Comparing the proportion of third age part-time workers to the percentage of the total workforce working part-time, we see that in general in the European Union older workers are more likely to have part-time jobs. Exceptionally, the occupational sector of 'sales workers' shows a percentage for third age part-time workers which is slightly below that for total employment. These results seem to indicate that part-time work for third age workers is indeed a way of gradually leaving the labour market.

Table 5.10. Part-time work by third age workers in the European Union in 1991 and \%-points change in the period 1987-1991

\begin{tabular}{lllll}
\hline occupation & $\begin{array}{l}1991 \\
\text { \% of third age } \\
\text { employment }\end{array}$ & $\begin{array}{l}1991 \\
\% \text { of total } \\
\text { employed }\end{array}$ & $\begin{array}{l}\text { 1987-1991 } \\
\text { \%-points change } \\
\text { female employed }\end{array}$ \\
\hline $0 / 1 \quad$ professional technical and related workers & 17.3 & 16.0 & 1.9 \\
$2 \quad$ administrative and managerial workers & 7.1 & 5.6 & 0.4 \\
$3 \quad$ clerical and related workers & 22.7 & 19.3 & 2.3 \\
$4 \quad$ sales workers & 20.4 & 20.9 & 0.9 \\
$5 \quad$ service workers & 40.9 & 33.8 & 3.6 \\
$6 \quad$ agricultural, animal husbandry and forestry & 13.0 & 11.0 & 0.7 \\
w/8/9 $\begin{array}{l}\text { prodkers fishermen and hunters } \\
\quad \text { equipment ond related workers, transport }\end{array}$ & 5.9 & 4.6 & 0.5 \\
& total & 17.3 & 15.0 & 1.5 \\
\hline
\end{tabular}




\subsection{Conclusion}

In this chapter we saw that approximately $10 \%$ of the total workforce in the European Union are third age workers. The third age workforce is active in all occupational sectors. However there are large differences between both occupational sectors and the various Member States. The Netherlands and Belgium, in particular, have relatively small proportions of third age workers, while the Southern European countries have the highest proportions. This may well be explained by the differences in social security between the various Member States. It was most striking that on average 1 out of 4 persons employed in the occupational sector of 'agricultural, animal husbandry and forestry workers, fishermen and hunters' belongs to the third age category. We also saw that third age workers have relatively small employment shares in the occupational sectors of 'professional, technical and related workers' and 'clerical and related workers'. For the first of these sectors the relatively low percentage of third age workers indicates that employment growth in this occupational sector in the last two decades has been realized, to a great extent, by youngsters entering the labour market and not by vertical mobility of older workers.

The largest group of third age workers (the European Union average was $29.7 \%$ ) work in the occupational sector of 'production and related workers, transport equipment operators and labourers'. The occupational sector of 'agricultural, animal husbandry and forestry workers, fishermen and hunters' is the second most important source of employment for third age workers.

Finally we saw that only a small number of older workers were looking for another job. The percentage of third age workers seeking a job is far below the figure for the total working population. The proportion of third age workers with temporary contracts is also very low (about half of that for total employment). We also saw that the percentage of third age workers with part-time jobs lies above that of total employment. Unfortunately it was not possible to give a reliable picture of the differences between the various Member States for these three indicators, because of the relatively large measurement errors in the survey data caused by the small numbers of third age workers in several countries. However, the data with regard to the European Union as a whole seems to indicate that in general there is great stability in employment relationships for third age workers. 


\section{CONCLUSION}

In this concluding chapter we will briefly summarize the various indicators of the occupational structure of employment in the European Union which have been presented in this study. Comments will be confined to the European Union as a whole: for more information on the individual Member States we refer to the various chapters of this report and their respective summaries. We will also make some suggestions for further research.

\section{Total employment}

Table 6.1 summarizes the various indicators of the occupational structure of employment for the European Union which have been presented in this study. When interpreting this table it must be remembered that the occupational sector of 'administrative and managerial workers' has caused difficulties throughout this report. As we saw before, these problems have probably been caused by differences in the interpretation of the definition of this category of workers between the various Member States.

In 1991 more than 108 million people were employed in the European Union ${ }^{23}$. This means that in the period 1987-1991 there was a net increase in total employment of 5.5 million workers. Remarkably, almost three quarters of this net employment increase have been captured by women. In contrast to this large employment growth for women, the employment share for older workers has decreased. This means that there is still no tendency towards an ageing workforce in the European Union.

The gross increase in employment in the growing occupational sectors in the period 1987-1991 amounts to 6.8 million jobs. However, as we can see in the table, agricultural occupations decreased by about 1.3 million jobs. Despite the decrease in employment in this occupational sector, the agricultural occupations have the most stable employment relationships. The decrease in employment in this occupational sector means that the agricultural occupations were the greatest occupational losers in the period 1987-1991. Another occupational loser was the occupational sector of 'production and related workers, transport equipment operators and labourers'. Although in this occupational sector total employment increased by 0.6 million jobs in the period 1987-1991, the employment share of this occupational sector decreased by 1.1 percentage points.

The greatest occupational winner was the 'professional, technical and related workers', with an absolute increase of $\mathbf{2 . 5}$ million jobs, which meant an increase in the employment share of this sector by 1.5 percentage points. The other occupational winners were the 'clerical and related workers'. In this occupational sector employment increased by almost 2 million jobs which meant an increase in the employment share of this occupational sector of $0.9 \%$. The two winning occupations have been responsible for more than $80 \%$ of the net employment increase in the European Union.

23. Italy excluded. 
It is remarkable that the two occupational winners show the highest average skill levels as well as the highest training participation rates, whereas the occupational losers show the lowest average skill levels and participation in training rates. These shifts in the occupational structure of employment therefore clearly indicate the upgrading of the (required) skill level of the working population in the European Union due to technological and organizational developments, as we can see that most new jobs have been created in the occupational sectors with the higher average skill levels.

Moreover, most occupational sectors show an increase in the average skill level in the period 1988-1991. Only the occupational sector of 'professional, technical and related workers' showed a slight decrease in the average skill level. The 'clerical and related workers' show the largest increase in the average skill level. In this sector both the employment shares of intermediate and highly skilled workers show an increase larger than average. The 'service workers' and 'production and related workers, transport equipment operators and labourers' show large increases in the employment share of intermediate skilled workers, and the occupational sector of 'administrative and managerial workers' showed a large increase in the employment share of highly skilled workers. More analyses should be done to determine to what extent this upgrading is related to shifts in the occupational structure, the sectoral structure, or the skill levels of employment.

The outcomes also indicate that apart from recruitment policies also training policies are important vehicles in the upgrading processes. As has been said before, the tow occupational winners show the highest training participation rates. Moreover, in most occupational sectors participation in training increased in the period 1987-1991. Especially, in the occupational sectors of 'administrative and managerial workers', 'clerical and related workers' and 'service workers' participation in training increased much. Remarkably, the occupational sectors of 'agricultural, animal husbandry and forestry workers, fishermen and hunters' and 'production and related workers, transport equipment operators and labourers', who already had the lowest participation in training rates, even showed tendencies towards a decrease in participation rates.

The shifts in the occupational structure of employment also fit very well within Clark's sector theory. This theory would lead us to expect a decrease in employment for 'production and related workers, transport equipment operators and labourers' and 'agricultural, animal husbandry and forestry workers, fishermen and hunters' and an employment increase in the occupational sectors of 'professional, technical and related workers', 'clerical and related workers' and 'administrative and managerial workers'. Except for the occupational sector of 'administrative and managerial workers' these shifts in the employment structure indeed occurred.

From the neo-classical point of view these shifts are not surprising either, as relatively high labour costs force the European Union to specialize in highly-skilled labour-intensive services and production work, while lower skilled labour-intensive production is eliminated. 
The labour market segmentation theory distinguishes between a primary 'better jobs' segment, and a secondary segment of the labour market. The proportion of the secondary segment in the occupational sectors determines, to a great extent, the stability of employment relations in the occupational sector. In chapter 3 we used indicators of job-search activity, part-time work and temporary contracts as measures for employment relationship stability. In general however, can be concluded that employment relationship stability in the European Union slightly increased in the period 1987-1991. On the one hand we saw that in the period 1987-1991 job-seeking decreased. On the other hand the other indicators showed an increase. The individual occupational sectors showed us that, especially 'agricultural, animal husbandry and forestry workers, fishermen and hunters' and 'administrative and managerial workers' have very stable employment relations, whereas 'service workers' have the most unstable employment relations.

The occupational sector of the 'service workers' is worth to analyze in more detail, as it is the sector with the most unstable employment relationships. In this occupational sector employment increased by 0.5 million jobs in the period 1987-1991, which meant that the employment share of this occupational sector stabilized. However, this occupational sector shows an average skill level significantly below the European average. This occupational sector also shows a rate of participation in training below average and above average rates of workers looking for another job, workers with temporary contracts and workers with part-time jobs. All in all, this occupational sector seems to be the least attractive to be employed in. As these characteristics indicate, many jobs in this occupational sector relate to the secondary segment of the labour market. It should be noticed that this occupational sector is the second largest sector in female employment. Two out of three people employed in this occupational sector are female.

More in general can be concluded, that although differences between the various Member States are still very large with regard to the indicators of occupational employment, a small converging trend can be noticed.

\section{Female employment}

The largest occupational sector for female employment is that of 'clerical and related workers'. The employment indicators for this occupational sector all lie on the positive side of the line. Again in this occupational sector two out of three persons employed are female. In the period 1987-1991, 1.5 million new jobs in this occupational sector have been occupied by women, i.e. more than $75 \%$ of all new jobs created in this occupational sector.

These developments in employment for female 'service workers' and female 'clerical and related workers' indicate a more or less dual process. On the one hand, as noted above, employment for female 'service workers' increased by 0.5 million in the period 1987-1991. In this period the number of women with temporary contracts and the number of women working part-time both increased by 0.3 million. This means that the new jobs in this sector that are occupied by women are, to a great extent, in the secondary segment of the labour market. On the other hand, the female 'clerical and related workers' are increasingly entering the primary labour 
market, as this occupational sector had the highest increase in the educational level of women workers. Over the period 1987-1991 the total number of women in this occupational sector with temporary contracts increased by 0.3 million, and the number of women working part-time increased by 0.6 million. This indicates that a large proportion of the 1.5 million new jobs in this sector which have been taken by women have been jobs in the primary labour market. Developments in the employment of 'professional and related workers' confirm that women are increasingly entering the primary labour market, as women have occupied 1.6 million of the 2.5 million new jobs in this highly skilled sector. Although the number of women with temporary contracts and part-time work in this sector increased by 0.5 million and 0.3 million respectively, the larger part of the new jobs for female workers in this sector have all the characteristics of the primary sector.

However, the data presented in chapter 4 show that most women are still employed in different occupations than male workers, as we see that women are still involved in care-giving jobs to a great extent. Moreover, in all occupational sectors women are under-represented among the workers with the higher educational levels, and they enjoy less stable employment relationships. However, as noted above, there is a tendency for more women to enter the primary segment of labour market. More evidence on this point could be presented if the occupational structure of female employment were to be analyzed at a lower level of aggregation (e.g. the ISCO 2-digit code).

\section{Older workers}

Chapter five showed us that the third age workforce is characterized by a great stability in employment relationships. The older worker is hardly ever looking for another job, and on average less than $5 \%$ of these workers have temporary contracts. However, third age workers are on average more likely to have part-time jobs than the total working population. One would assume that the larger proportion of third age workers working part-time do so voluntarily. It is quite remarkable that the occupational sector of 'production and related workers, transport equipment operators and labourers' proved to be the greatest occupational winner for the third age workforce, whereas it was an occupational loser for both women and total employment. This indicates the increasing ageing of this occupational sector. The greatest occupational loser in third age employment was the occupational sector of 'agricultural, animal husbandry and forestry workers, fishermen and hunters', in which employment for third age workers decreased by 0.3 million jobs. However this occupational sector still employs the second highest proportion of older workers. In general we did not find indications of a growing input from third age workers in the European Union. Probably the various early retirement schemes in the Member States have restricted the ageing of the workforce to a great extent.

\section{Further research}

In this exploratory study, based on the available EUROSTAT data by occupation and education, we have not been able to tackle all the issues we dealt with in full depth. Therefore we will make some recommendations for further research. 
As already noted, it is important to analyze the upgrading processes in the European Union further. By means of a shift-share analysis it would be possible to determine to what extent the upgrading processes are related to shifts in the occupational, skill level or sectoral structure of employment.

In particular, if adequate occupational data at 2-digit level was available, a much more thorough analysis would be possible with regard to all the indicators presented in this report.

Another interesting subject for further research would be to analyze the labour market position of youngsters. What jobs do they get? How many jobs are available for them? For these questions it is important that the analysis of employment growth should be extended to include an analysis of replacement demand due to early retirement, job-mobility, temporary withdrawal, etcetera, as for most occupational groups this replacement demand is much more important in determining the job-openings for newcomers on the labour market than the employment growth. ${ }^{24}$ The data from EUROSTAT does offer possibilities for this kind of analysis.

A last option for further research would be to explore the various aspects of the position of migrants on the Member States' labour markets. Occupational data at the 2-digit level would also increase the policy-relevance of these analyses.

24. See for further information on this subject De Grip, Meijboom and Willems (1993). 


\section{REFERENCES}

Bartel, A.P., F.R. Lichtenberg (1987), The comparative advantage of educated workers in implementing new technology, The Review of Economics and Statistics, Number 1, 1987, pp. $1-11$.

Becker, G.S. (1983), Human capital, University of Chigaco Press, reprint.

Chacholiades, M. (1978), International trade theory and policy, McGraw-Hill, London.

Clark, C. (1940), The conditions of economic progress, MacMillan, London.

Dale, A. and J. Glover (1990), An analysis of women's employment patterns in the UK, France and the USA, The value of survey based comparisons, Employment Department Group Research Paper no. 75, London.

De Grip, A., P. Meijboom, E.J.T.A. Willems (1993), Vacancies, employment growth and the demand for newcomers on the labour market, Maastricht.

Doeringer, P.B., M.J. Piore (1971), Internal labor markets and manpower analysis, Heath, Lexington.

Dosi, G., K. Pavitt, L. Soete (1990), The economics of technical change and international trade, Harvester Wheatseaf, New York.

Ethier, J.E. (1988), Modern International economics, W.W. Norton \& Company, London.

Groot, W. (1991), Scholing, arbeidsmarkt en economische ontwikkeling, VUGA, Den Haag.

Heijke, J.A.M., A. de Grip (1991), The information system on education and the labour market developed by ROA, Maastricht.

Leontief, W.W. (1953), Domestic production and foreign trade; the American position reexamined, Proceedings of the American Philosophical Society, vol. 97, pp. 332-349.

Lindley, R., R. Wilson, E. Villagomez (1992), Labour market prospects for the third age, Warwick.

Ryan, P. (1991), International comparisons of vocational education and training for intermediate skills, The Falmer Press, New York.

Siegers, J.J. (1979), Beroepssegregatie tussen mannen en vrouwen in Nederland, Economische Statistische Berichten, jrg. 64, nr. 3194, pp. 208-213.

Spenner, K.I. (1985), The upgrading and downgrading of occupations: Issues, evidence and implications for education, Review of Educational Research, vol. 55, pp. 125-154. 


\section{APPENDIX 1. ISCO '68}

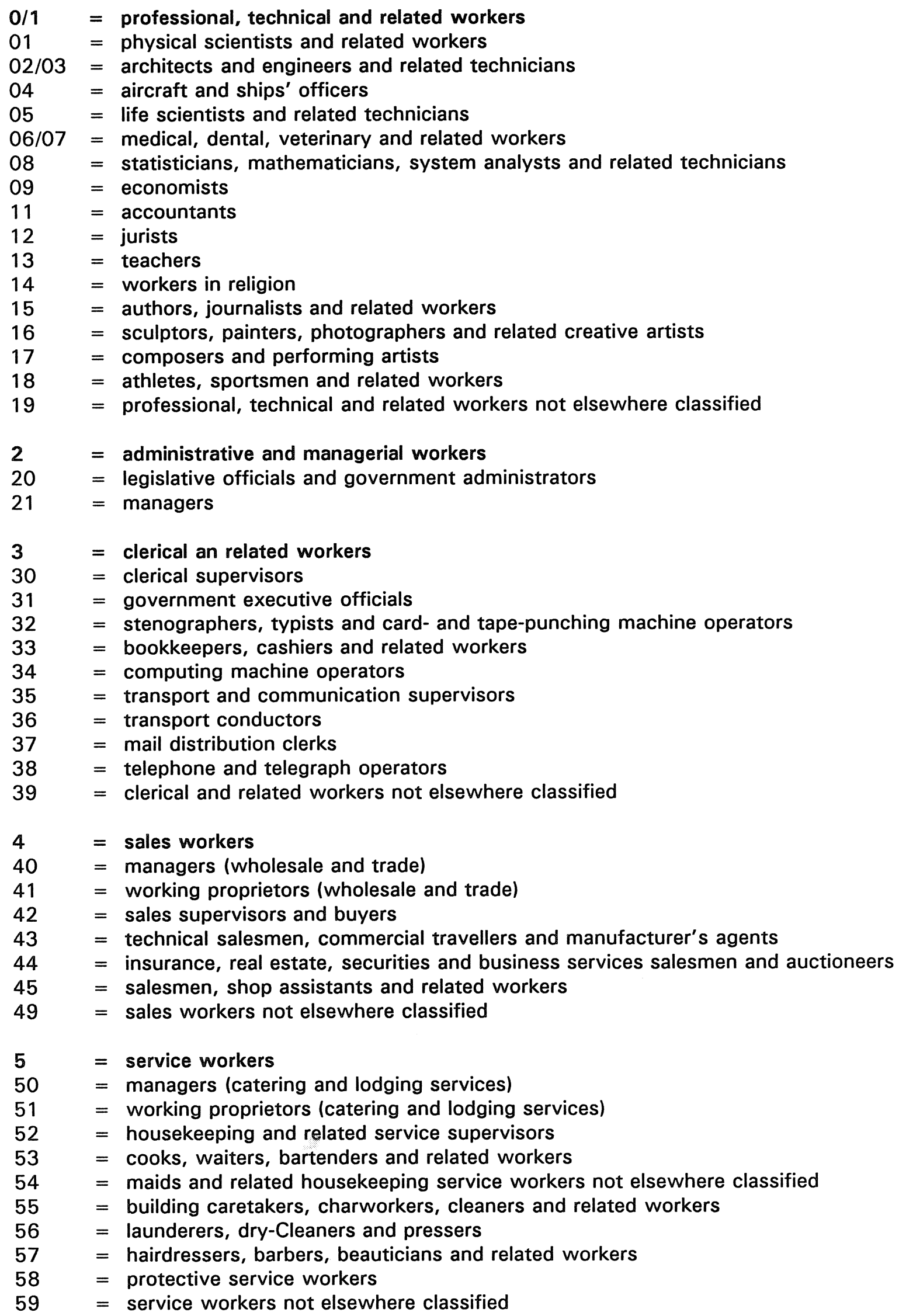




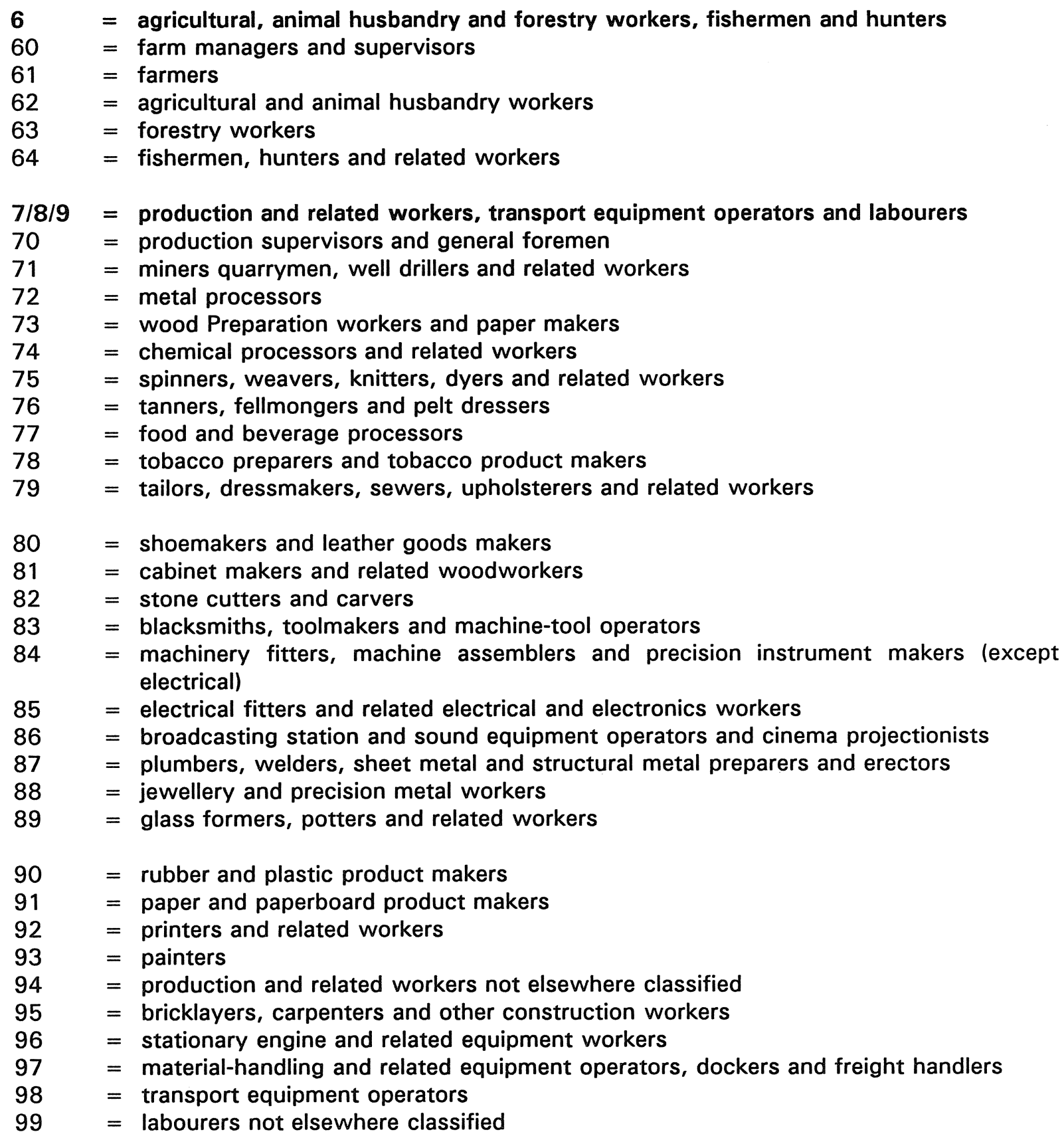

